\title{
Accessing 1,2-Amino Alcohols and Diols through Photocatalytic Anti-Markovnikov Difunctionalisation of Ene-Carbamates and Enol Ethers
}

\author{
Stephanie G. E. Amos, Stefano Nicolai, Jerome Waser* \\ Laboratory of Catalysis and Organic Synthesis, Institut des Sciences et Ingénierie Chimique, Ecole Polytechnique Fédérale \\ de Lausanne, CH-1015, Lausanne, Switzerland
}

Photoredox Catalysis; Alkene Functionalization; Alkynes; Hypervalent Iodine

\begin{abstract}
We report an atom-economical 1,2-oxyalkynylation of ene-carbamates and enol ethers based on the use of Ethynyl BenziodoXolone (EBX) as dual reagents for alkyne and oxygen transfer. The reaction occurs at room temperature under blue LED irradiation using an organic dye as a photocatalyst. A broad variety of 1-alkynyl-1,2-amino-alcohol and 1-alkynyl-1,2-diol scaffolds were obtained in up to $89 \%$ yield with anti-Markovnikov regioselectivity. The reaction is speculated to proceed via oxidation of the double bond to give a radical cation intermediate, enabling the selective difunctionalization of electron-rich alkenes.
\end{abstract}

Accessing 1,2-amino-alcohols and 1,2-diols has been a longstanding target in synthetic methodology. The interest in such scaffolds lies within their multiple applications in pharmaceutical, material and agrochemical sciences. ${ }^{1,2}$ Enamides and ene-carbamates are particularly versatile starting materials for the generation of complex aminated building blocks. ${ }^{3-8}$ In particular they have been used extensively in atom transfer radical addition (ATRA) reactions. ${ }^{9}$ Due to their innate nucleophilicity, they are excellent traps for electrophilic radicals, leading to the formation of a nucleophilic $\alpha$-amino radical I (Scheme 1, A). The latter can then undergo oxidation, ${ }^{10-12}$ reduction, ${ }^{13}$ addition to a radical trap ${ }^{14}$ or addition to a metallic species followed by reductive elimination. ${ }^{15}$ Despite the efficiency associated to such a transformation, the addition to the alkene requires highly reactive electrophilic radicals, limiting structural diversity of the obtained products.

Ethynyl BenziodoXolone (EBX) reagents have been identified as efficient traps for nucleophilic radicals such as $\alpha$-amino radicals. ${ }^{16-19}$ Their application in radical-mediated olefin alkynylation is also established. ${ }^{20-24}$ Nevertheless, these methods often rely on the generation of highly reactive free radicals and/or on strong oxidative conditions, which can result in poor functional group tolerance. Furthermore, all transformations entail the loss of iodobenzoate in stoechiometric quantities, resulting in poor atom economy. Recently, our group has developed atom-economical reactions of EBXs such as the 1,1 oxyalkynylation of diazo compounds and the ring-opening/oxyalkynylation of thiiranes. ${ }^{25-28}$ These strategies allow the introduction of the versatile alkyne and an ester functionality that can be easily cleaved to the alcohol. ${ }^{25}$ For what concerns alkene 1,2-difunctionalization with benziodoxole reagents, the Sodeoka and Gillaizeau groups reported a copper-catalyzed alkene oxytrifluoromethylation (Scheme 1, B, a: $\left.\mathrm{X}=\mathrm{CF}_{3}\right)^{29}$ and an iron-catalyzed enamide oxyazidation $\left(\mathbf{B}, \mathrm{b}: \mathrm{X}=\mathrm{N}_{3}\right)^{30}$ reactions with Togni's and Zdhankin's reagents respectively. The only example involving EBXs is a gold catalysed 1,2-oxyalkynylation of allenenamides reported by the Patil group $(\mathbf{B}, \mathrm{c}$, $\mathrm{X}=$ alkynyl).$^{31}$ Consequently, all previous methods for atomeconomical 1,2-addition of benziodoxole reagents onto olefins are based on metal catalysis, and 1,2-oxyalkynylation remains limited to allenenamides as substrates.

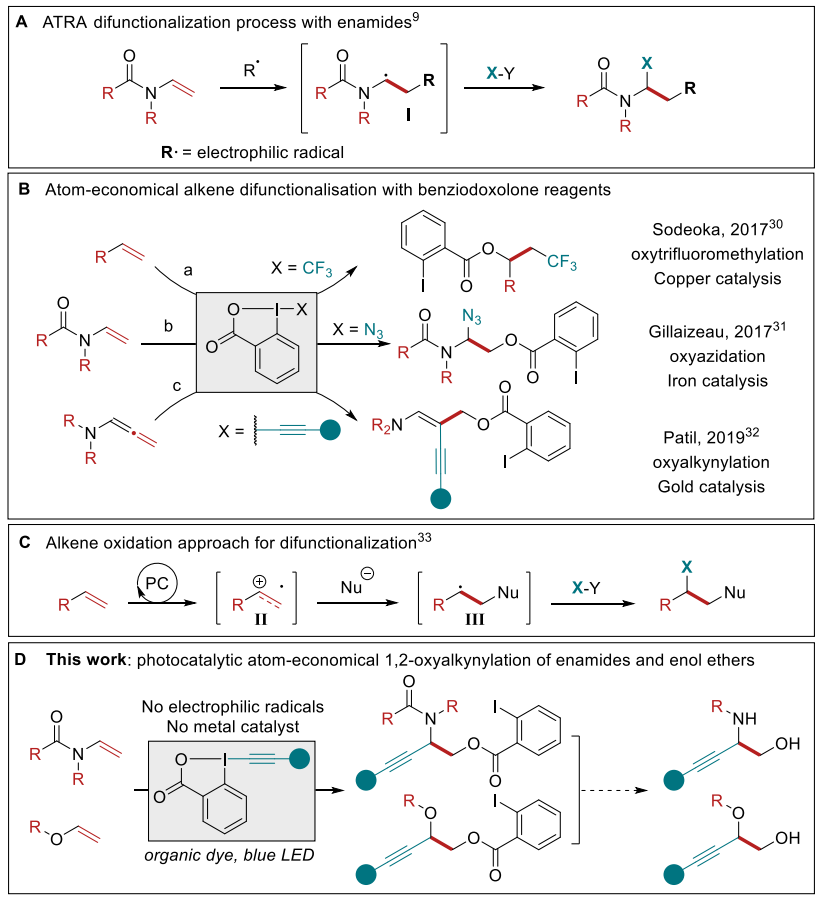

Scheme 1. State of the art. (A) Enamide ATRA reactions. (B) Atom-economical alkene difunctionalisation with benziodoxolone reagents. (C) Alkene oxidation for difunctionalization. (D) This work: photocatalytic atom-economical synthesis of 1-propargyl-1,2-amino alcohols and diols. 
With the goal of extending the scope of alkene difunctionalization, Nicewicz and co-workers developed a different approach based on the oxidation of alkenes under photoredox conditions for the generation of radical cation II (Scheme $1, \mathbf{C}){ }^{32-}$ ${ }^{34}$ The key nucleophilic radical III is then generated by addition of a nucleophile, alleviating the need for highly reactive electrophilic radicals as partners. This strategy was applied to numerous hydrofunctionalisations of alkenes, including hydrocarboxylation, hydrochlorination and hydroazidation. ${ }^{35-40}$ Whereas their main focus was on aliphatic alkenes and styrenes, one example of an ene-carbamate was also reported. ${ }^{37}$ Based on this precedence and the recent independent studies of Zeitler's and our groups, ${ }^{41-43}$ we hypothesised that a finely tuned organic dye could perform the oxidation of ene-carbamates to generate a radical cationic species under photoredox conditions. With their dual oxygen-nucleophile/radical trap nature, EBX reagents would then be ideally suited to react with such an intermediate, enabling an atom-economical 1,2-oxyalkynylation of alkenes without the need for highly reactive electrophilic radicals.

In this study, we show that radical cations, generated by oxidation of ene-carbamates under photoredox conditions using an organic dye, can indeed react in an atom-economical fashion with EBX reagents (Scheme 1, D). This methodology could then be extended to commercially available enamides and enol ethers. The mild oxidative conditions allowed selective reaction of electron-rich alkenes in presence of non-activated ones. This procedure provides easy access to protected 1-alkynyl-1,2-amino alcohols and 1-alkynyl-1,2-diols, which are valuable intermediates in the synthesis of natural and synthetic bioactive compounds. ${ }^{44-48}$

Based on previous reports for enamide difunctionalisation and $\alpha$-amino radical alkynylation, ${ }^{14}$ we started our investigations with easily accessible $N$-vinyloxazolidinone $(\mathbf{1 a})^{49}$ and the efficient radical trap $\mathrm{Ph}-\mathrm{EBX}(\mathbf{2})^{50}$ as test substrate and reagent (Table 1). The oxidation potential of $\mathbf{1 a}$ was first determined to be $+1.30 \mathrm{~V}$ vs SCE by cyclic voltammetry. Based on this result, we selected three organic photocatalysts (PC) for their oxidative properties in the excited state: $4-\mathrm{CzIPN}\left(\mathbf{4} \mathbf{a}^{*} / \mathbf{4} \mathbf{a}^{*-}:+1.35 \mathrm{~V}\right.$ vs SCE), 4-ClCzIPN $\left(\mathbf{4} \mathbf{b}^{*} / \mathbf{4} \mathbf{b}^{*}:+1.58 \mathrm{~V}\right)$ and Mes-Acr $^{+}\left(\mathbf{5}^{+*} / \mathbf{5}^{*}\right.$ : $+2.06 \mathrm{~V}){ }^{40,42}$ Using DCE as a solvent and 1.5 equivalents of alkene both $\mathbf{4 a}$ and $\mathbf{4 b}$ enabled product formation (entries 1 and 2). $\mathbf{4 b}$ gave a promising $42 \%$ yield of the desired compound $\mathbf{3 a}$ upon the first attempt (entry 2). Highly oxidizing 5 resulted in a $5 \%$ yield (entry 3 ). At this point, we observed that the yield obtained was dependant on the batch of benziodoxolone 2 when using photocatalyst $\mathbf{4 b}$ (entry 4 ). We noticed that with a recrystallised batch (as opposed to a batch purified by trituration only $)^{50,51}$ our yields were reproducible yet low (entry 5). We speculated that an impurity from the triturated batch was affecting the reactivity. As the most probable impurities were not alkynylated iodine(III) precursors, we investigated hydroxy and acetoxy benziodoxolones as additives $(\mathrm{BIOH}, 6$ and BIOAc, $7) .{ }^{52}$ Adding 7 ( 1.5 equiv., entry 6 ) only improved slightly the yield. However, with 7 ( 1.5 equiv., entry 7 ), the yield increased to $70 \%$. With 0.5 equivalent of 7 , the yield remained in the same range (75\%, entry 8$)$. Both DMSO and DCM could also be used as solvents (entries 9 and 10). ${ }^{53}$ Final adjustments were made on scope scale $(0.2 \mathrm{mmol})$ : DCM was used as a solvent with a lower catalyst loading of $2 \mathrm{~mol} \%$ and an increase of the concentration to $0.25 \mathrm{M}$. This gave product $3 \mathbf{a}$ in $80 \%$ yield (entry 11 ). Finally, we tested ruthenium based photocatalyst $\mathbf{8}$, which has a comparable oxidation potential $\left(\mathrm{Ru}^{2+*} / \mathrm{Ru}^{+}:+1.40 \mathrm{~V}\right), 3 \mathrm{a}$ was only obtained in $21 \%$ yield (entry 12 ). This result may have its origin from the weaker reduction potential of $\mathbf{8}\left(\mathrm{Ru}^{2+} / \mathrm{Ru}^{+}:-0.80\right.$ $\mathrm{V})$, compared to $\mathbf{4 b}\left(\mathbf{4 b} / \mathbf{4} \mathbf{b}^{\bullet}:-1.10 \mathrm{~V}\right)$.

With the optimised reaction conditions in hand, we explored the scope of the reaction (Scheme 2). Acyclic ene-carbamates were tolerated affording Boc and $\mathrm{Cbz}$ protected amines $\mathbf{3 b}$ and $3 \mathbf{c}$ in $63 \%$ and $86 \%$ yield. Although $\mathrm{N}-\mathrm{H}$ vinyl carbamates degraded under the reaction conditions, the orthogonally diprotected ene-carbamate 1d was successfully converted to $\mathbf{3 d}$ in $73 \%$ yield. A methyl amine worked well under our reaction conditions (3e, 83\% yield) and allyl amine was also tolerated affording $3 \mathrm{f}$ in $54 \%$ yield, ${ }^{54}$ demonstrating that selective functionalization of ene-carbamates in presence of an alkene was possible. Substrates bearing a silylated alcohol and an ethyl ester yielded the desired compounds $\mathbf{3 g}$ and $\mathbf{3 h}$ in $52 \%$ and $69 \%$ yield. Our procedure also worked well with secondary amines (3i, $65 \%$ yield). We could also perform this transformation on enamides such as commercial $N$-vinylpyrrolidinone yielding compound $\mathbf{3 j}$ in $85 \%$ yield. $\alpha$-Substitution of the alkene was unfortunately not tolerated (1k no conversion) and $\beta$-substituted $(E)$-ene-carbamate afforded afforded $\mathbf{3 l}$ as a mixture of diastereoisomers in $80 \%$ yield (3:1 dr.).

\section{Table 1. Optimisation of the reaction conditions}

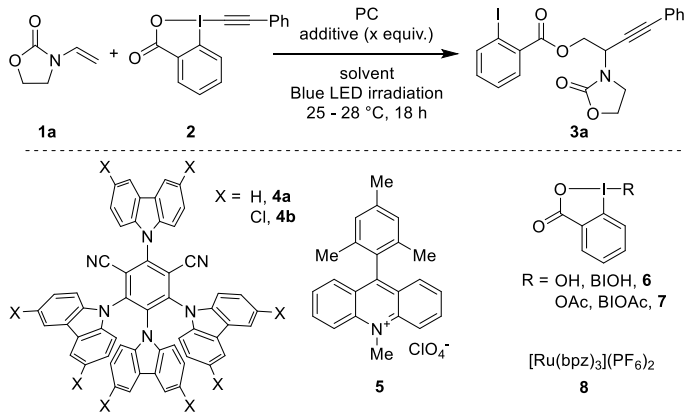

\begin{tabular}{|c|c|c|c|c|}
\hline entry & PC & $\begin{array}{c}\text { additive (x } \\
\text { equiv.) }\end{array}$ & solvent & yield $(\%)^{a}$ \\
\hline 1 & $4 a$ & None & DCE & 30 \\
\hline 2 & $4 b$ & None & DCE & 42 \\
\hline 3 & 5 & None & DCE & 5 \\
\hline 4 & $4 b$ & None & DCE & $36-65$ \\
\hline $5^{b}$ & $4 b$ & None & DCE & 34 \\
\hline $6^{b}$ & $4 b$ & $\mathrm{BIOH}(6,1.5)$ & DCE & 46 \\
\hline $7^{b}$ & $4 b$ & BIOAc $(7,1.5)$ & DCE & 70 \\
\hline $8^{b}$ & $4 b$ & BIOAc $(7,0.5)$ & DCE & 75 \\
\hline $9^{b}$ & $4 b$ & $\operatorname{BIOAc}(7,0.5)$ & DMSO & 75 \\
\hline $10^{b}$ & $4 b$ & $\operatorname{BIOAc}(7,0.5)$ & DCM & 80 \\
\hline $11^{b}$ & $4 b^{c}$ & $\operatorname{BIOAc}(7,0.5)$ & $\mathrm{DCM}^{d}$ & 80 \\
\hline $12^{b}$ & $8^{c}$ & BIOAc $(7,0.5)$ & $\mathrm{DCM}^{d}$ & 21 \\
\hline
\end{tabular}

Reactions conditions: 0.05 mmol 2 (1 equiv.), 1a (1.5 equiv.), additive (x equiv.) and $\mathrm{PC}(5 \mathrm{~mol} \%)$ in solvent $0.1 \mathrm{M}$ unless specified otherwise. Blue led irradiation for $18 \mathrm{~h}$ at rt. ${ }^{a 1} \mathrm{H}$ NMR yield determined by addition of $0.05 \mathrm{mmol}$ of $\mathrm{CH}_{2} \mathrm{Br}_{2}$ as an internal standard after the reaction. ${ }^{b}$ recrystalised 2. ${ }^{c} 2 \mathrm{~mol} \%$. ${ }^{d}$ concentration based on 2: $0.25 \mathrm{M}$.

Finally, we examined our reaction conditions on enol-ethers, which have comparable oxidation potentials (eg. dihydropyran (DHP, 9i), 1.51 V vs SCE). To our delight, with no modification 
to our reaction conditions, we were able to obtain aliphatic (10a), benzylic (10b) and allylic (10c) ethers in 89\%, 58\% and $46 \%$ yield. The chlorinated product 10d was obtained in $77 \%$ yield. In addition, a secondary enol ether afforded 10e in $62 \%$ yield. Although $\alpha$-substituted ene-carbamates were not tolerated (1k, no conv.), tertiary ether $\mathbf{1 0 f}$ could be obtained from propen-2-yl enol ether in $82 \%$ yield. $\beta$-substitution afforded a mixture of compounds, from which acetal 10ga corresponding to Markovnikov addition could be isolated in $13 \%$ yield. ${ }^{55} \mathrm{Fi}$ nally, DHP $9 \mathbf{h}^{55}$ afforded two regiosiomers: Anti-Markovnikov product 10ha (58\% yield) and Markonikov product 10hb (15\% yield). ${ }^{56}$

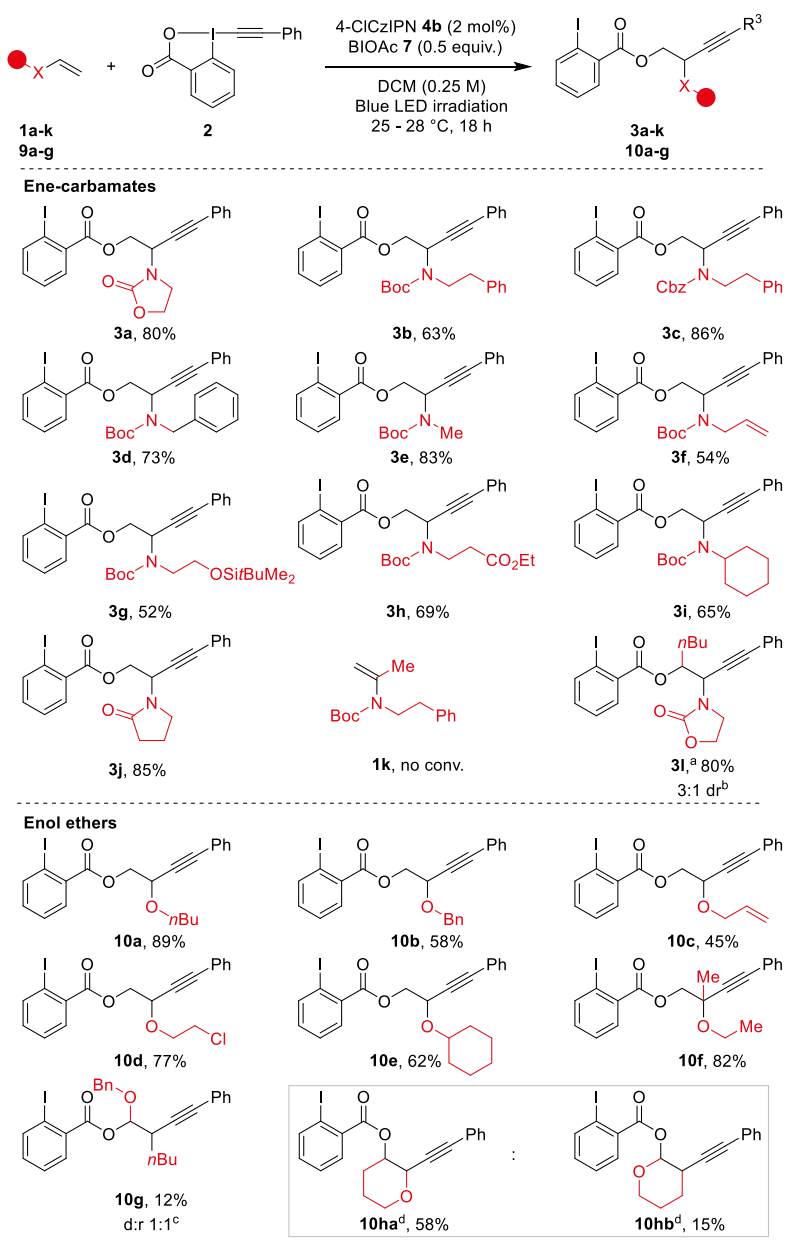

Scheme 2. Scope of ene-carbamates and enol ethers. Reactions conditions: $0.20-0.25$ mmol 2 (1 equiv.), alkene (1.5 equiv.), BIOAc (7, 0.5 equiv.) and $4 \mathbf{b}(2 \mathrm{~mol} \%)$ in DCM $0.25 \mathrm{M}$. Blue led irradiation for $18 \mathrm{~h}$ at rt. ${ }^{\mathrm{a}}$ Obtained from both $(E)$-1l and $(Z)$ 11. ${ }^{b}$ Isolated ratio. ${ }^{\mathrm{c} 1} \mathrm{H} \mathrm{NMR}$ ratio. ${ }^{\mathrm{d}} \mathbf{1 0 h a}$ and $\mathbf{1 0 h b}$ were obtained as an inseperable mixture of regioisomers from $9 \mathbf{i}$ using 1.5 equiv. of 7 .

Having explored the scope of ene-carbamates and enolethers, we then examined diverse EBX reagents (Scheme 3). Both electron-poor and electron-rich arenes on the alkyne provided the desired compounds $\mathbf{1 2} \mathbf{a}-\mathbf{1 2 e}$ in up to $76 \%$ yield. The transfer of a silyl protected alkyne was less efficient and product 12f was obtained in $9 \%$ yield only. EBXs bearing sensitive functionalities such as an alkyl bromide or a terminal alkene gave the corresponding products $\mathbf{1 2}$ g and $\mathbf{1 2 h}$ in $51 \%$ and $37 \%$ yield respectively. Functionalized EBXs could also be used with enol ether $\mathbf{9 a}$ affording $\mathbf{1 2} \mathbf{i}$ and $\mathbf{1 2} \mathbf{j}$ in $62 \%$ and $52 \%$ yield.
We then investigated the mechanism of the reaction. We first performed the reaction without the photocatalyst and/or a light source (Scheme 4, A, eq. a). No product was detected confirming that the transformation is photomediated. We then considered the possibility of an ATRA reaction. For this, acyloxyl radical Ia (Scheme 4, B) would add to the electron rich olefin 1a. Previously, radical Ia (which is a resonance structure of the iodanyl radical Ib) has been reported predominantly as a $\mathrm{H}$ atom abstractor. ${ }^{57-59}$ To the best of our knowledge, the only proposed report of Ia adding to an alkene is that of the Gillaizeau group. ${ }^{30}$ Chen and co-workers previously reported the generation of radical Ia through a slow reduction of BIOAc (7) by excited $\mathrm{Ru}(\mathrm{bpy})_{3}{ }^{2+52}$ With this photocatalyst, we observed no conversion or product formation (eq. b). This suggests that the generation of Ia alone does not lead to product formation. This could be further confirmed with substrate $\mathbf{1 k}$, which is tougher to oxidize $\left(1 \mathbf{k}^{*+} / \mathbf{1 k} \approx 1.86 \mathrm{~V}\right)$. No conversion was observed under the optimised reaction conditions (Scheme 2). At least some conversion would have been expected if the reaction proceeded through the addition of oxygen-centred radical Ia. In addition, $\beta$-substituted alkene $\mathbf{1 1}$ gave oxyalkynylation product $\mathbf{3 1}$ in $80 \%$ yield with the same efficiency as for terminal enamide 1a. An ATRA process would have been more significantly impaired by the substituent. The observed anti-Markovnikov selectivity is also in agreement with the reactivity reported for radical cations. ${ }^{34}$ When the reaction was performed with a $2: 1$ ratio of $Z$ and $E$ isomers of $\mathbf{1 l}$ instead of pure $E$ compound, no change in yield and diastereoselectivity was observed, supporting the presence of a radical intermediate (eq. c). With the strong oxidizing catalyst $\mathbf{5}$, low yields were observed even in presence of BIOAc (7), despite almost full conversion of the ene-carbamate 1a (eq. e).

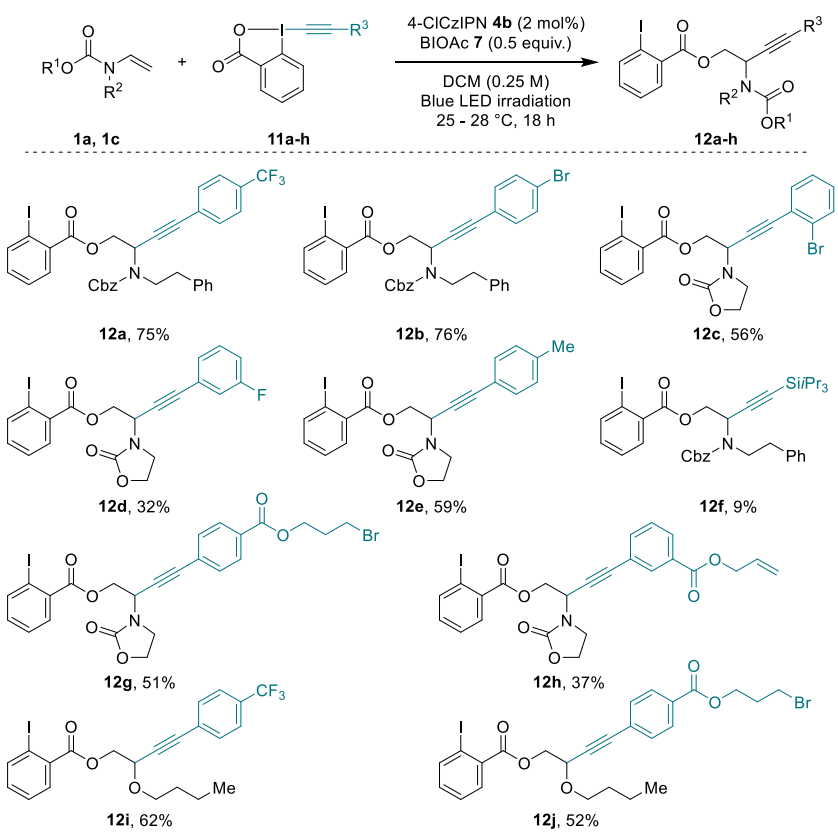

Scheme 3. Scope EBX reagents. Reactions conditions: 0.25 mmol 11a-h (1 equiv.), 1a or 3a (1.5 equiv.), BIOAc (7, 0.5 equiv.) and $4 \mathbf{b}(2 \mathrm{~mol} \%)$ in DCM $0.25 \mathrm{M}$. Blue led irradiation for $18 \mathrm{~h}$ at $\mathrm{rt}$.

Based on these results, we propose a tentative mechanism for the oxyalkynylation (Scheme 4, B). First, the excited photocatalalyst $\mathbf{4 b}^{*}$ oxidises 1a generating the radical cation II and the 
reduced catalyst $\mathbf{4} \mathbf{b}^{-*}$. Then II is trapped by carboxylate III. This results in the formation of the nucleophilic radical IV which can add to $\mathbf{2}$ affording the desired compound and iodanyl radical $\mathbf{I b}$ which in turn can close the catalytic cycle by oxidizing $\mathbf{4} \mathbf{b}^{-*}$ to regenerate ground state catalyst $\mathbf{4 b} .^{60} \mathrm{We}$ suspect that BIOAc (7) serves as initiator for the reaction by generating Ia via reduction of BIOAc (7) with the excited state photocatalyst $4 \mathbf{4} \mathbf{b}$. The resulting oxidized catalyst $\mathbf{4} \mathbf{b}^{+}$would be also competent to oxidize 1a. Later, this pathway would help sustaining the catalytic cycle by ensuring a sufficient concentration of radical Ia. With highly oxidising $\mathbf{5}$, formation of radical cation II should also occur, as supported by full conversion of the enamide. However, the yield of $\mathbf{3 a}$ is low, this may be either due to a lower efficiency in the proposed reduction steps or to the over oxidation of $\alpha$-amino radical $\mathbf{I V}$.

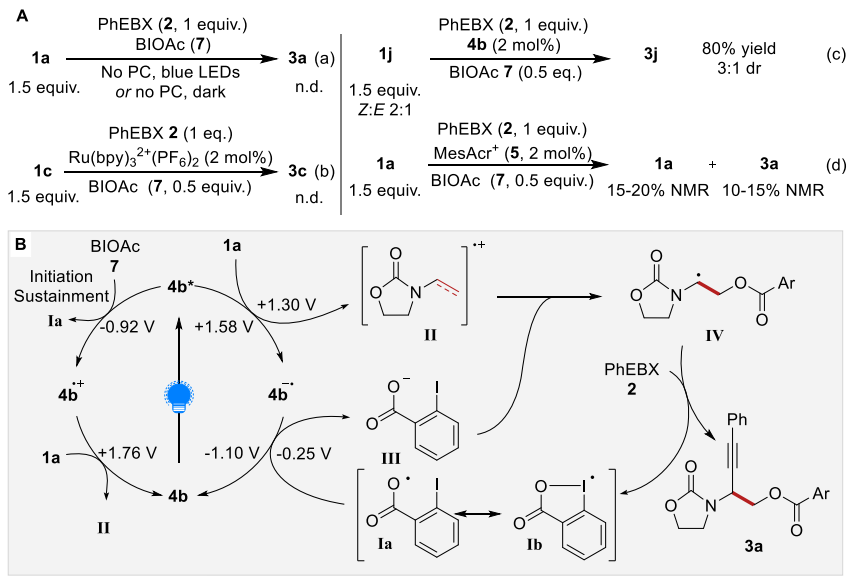

Scheme 4. Mechanistic studies. (A) Control experiments Reaction conditions: $0.05-0.25 \mathrm{mmol} 2$ (1 equiv.), 1 (1.5 equiv.), additive (x equiv.), PC (2 mol\%), DCE or DCM (0.25 M). (B) Proposed mechanism.

To demonstrate the synthetic utility of this transformation, we performed the transformation on gram scale (Scheme 5, eq. a), affording $\mathbf{3 j}$ in $64 \%$ yield $(0.998 \mathrm{~g})$. Selective hydrolysis of the ester group from $\mathbf{3 j}$ gave $\mathbf{1 3}$ in $96 \%$ yield (Scheme 5, eq. b). Hydrolysis of 10a provided 14 in $91 \%$ yield (Scheme 5, eq. c). Finally, 3b underwent Boc deprotection to give amino ester $\mathbf{1 5}$ in $74 \%$ yield (Scheme 5 , eq. d).

In conclusion, we have developed a photocatalytic anti-Markovnikov 1,2-oxy-alkynylation of ene-carbamates. The transformation proceeds in an atom-economical fashion with EBXs acting both as alkynylating and carboxylating reagents. The reaction occurs at room temperature under blue LED irradiation using 4-ClCzIPN (4b) as an organic photocatalyst and does not require the formation of highly reactive electrophilic radicals. The methodology could be extended to enamides and enolethers using the same reaction conditions. The method shows good chemoselectivity for nitrogen or oxygen-substituted olefins over aliphatic alkenes. Based on preliminary mechanistic studies, we propose that the ene-carbamate radical cation is the key intermediate that ensures the anti-Markovnikov regioselectivity. This reaction allows quick access to protected 1-alkynyl-1,2-amino alcohols and 1-alkynyl-1,2-diols, which are important building blocks in agrochemical, pharmaceutical and material sciences.

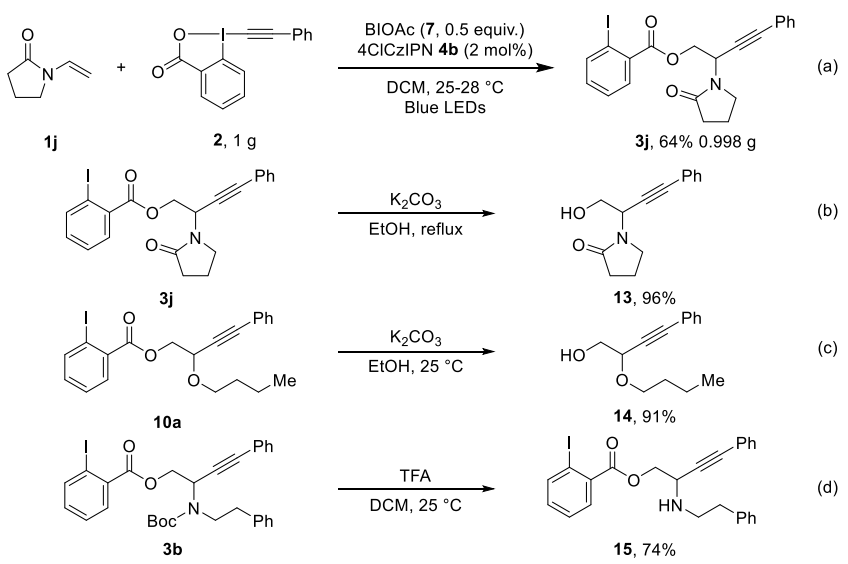

Scheme 5. Scale-up and functionalization of the products.

\section{ASSOCIATED CONTENT}

\section{Supporting Information}

The Supporting Information, including experimental procedures, characterization data and copy of NMR spectra, is available free of charge.

\section{AUTHOR INFORMATION}

\section{Corresponding Author}

*jerome.waser@epfl.ch

\section{ACKNOWLEDGMENT}

We thank EPFL for financial support.

\section{REFERENCES}

(1) Lawrence, S. A. Amines: Synthesis, Properties, and Applications; Cambridge University Press: New York, 2004.
Amino Group Chemistry: From Synthesis to the Life Sciences; Ricci, A., Ed.; John Wiley \& Sons, Inc: Weinheim, 2008.

Matsubara, R.; Kobayashi, S. Enamides and Enecarbamates as Nucleophiles in Stereoselective $\mathrm{C}-\mathrm{C}$ and $\mathrm{C}-\mathrm{N}$ Bond-Forming Reactions. Acc. Chem. Res. 2008, 41, 292-301.

Gopalaiah, K.; Kagan, H. B. Use of Nonfunctionalized Enamides and Enecarbamates in Asymmetric Synthesis. Chem. Rev. 2011, 111, 4599-4657.

Bernadat, G.; Masson, G. Enamide Derivatives: Versatile Building Blocks for Highly Functionalized $\alpha, \beta$-Substituted Amines. Synlett 2014, 25, 2842-2867.

Gigant, N.; Chausset-Boissarie, L.; Gillaizeau, I. Direct Metal-Catalyzed Regioselective Functionalization of Enamides. Chem. - Eur. J. 2014, 20, 7548-7564.

Courant, T.; Dagousset, G.; Masson, G. Enamide Derivatives: Versatile Building Blocks for Total Synthesis. Synthesis $\mathbf{2 0 1 5}$ 47, 1799-1856.

Cai, X.; Yang, M.; Guo, H. Tertiary Enamides: Versatile and Available Substrates in Synthetic Chemistry. Curr. Org. Synth. 2019, 16, 70-97.

Courant, T.; Masson, G. Recent Progress in Visible-Light Photoredox-Catalyzed Intermolecular 1,2-Difunctionalization of Double Bonds via an ATRA-Type Mechanism. J. Org. Chem. 2016, 81, 6945-6952.

Carboni, A.; Dagousset, G.; Magnier, E.; Masson, G. Photoredox-Induced Three-Component Oxy-, Amino-, and Carbotrifluoromethylation of Enecarbamates. Org. Lett. 2014, 16, 1240-1243.

de Souza, E. L. S.; Wiethan, C.; Correia, C. R. D. Iron-Catalyzed Meerwein Carbooxygenation of Electron-Rich Olefins: 
Studies with Styrenes, Vinyl Pyrrolidinone, and Vinyl Oxazolidinone. ACS Omega 2019, 4, 18918-18929.

(12) Kramer, P.; Halaczkiewicz, M.; Sun, Y.; Kelm, H.; Manolikakes, G. Iron(III)-Mediated Oxysulfonylation of Enamides with Sodium and Lithium Sulfinates. J. Org. Chem. 2020, 85, 3617-3637.

(13) Fu, Q.; Bo, Z.-Y.; Ye, J.-H.; Ju, T.; Huang, H.; Liao, L.-L.; $\mathrm{Yu}, \mathrm{D}$.-G. Transition Metal-Free Phosphonocarboxylation of Alkenes with Carbon Dioxide via Visible-Light Photoredox Catalysis. Nat. Commun. 2019, 10, 3592.

(14) Poittevin, C.; Liautard, V.; Beniazza, R.; Robert, F.; Landais, Y. Free-Radical Carbo-Alkenylation of Enamides and EneCarbamates. Org. Lett. 2013, 15, 2814-2817.

(15) Xu, C.; Yang, Z.-F.; An, L.; Zhang, X. Nickel-Catalyzed Difluoroalkylation-Alkylation of Enamides. ACS Catal. 2019, 9, 8224-8229.

(16) Hari, D. P.; Nicolai, S.; Waser, J. Alkynylations and Vinylations. In PATAI'S Chemistry of Functional Groups; 2018; pp $1-58$.

(17) Liu, X.; Wang, Z.; Cheng, X.; Li, C. Silver-Catalyzed Decarboxylative Alkynylation of Aliphatic Carboxylic Acids in Aqueous Solution. J. Am. Chem. Soc. 2012, 134, 14330 14333.

(18) Zhou, Q.; Guo, W.; Ding, W.; Wu, X.; Chen, X.; Lu, L.; Xiao, W. Decarboxylative Alkynylation and Carbonylative Alkynylation of Carboxylic Acids Enabled by Visible-Light Photoredox Catalysis. Angew. Chem. Int. Ed. 2015, 54, 11196-11199.

(19) Le Vaillant, F.; Courant, T.; Waser, J. Room-Temperature Decarboxylative Alkynylation of Carboxylic Acids Using Photoredox Catalysis and EBX Reagents. Angew. Chem. Int. Ed. 2015, 54, 11200-11204

(20) Shen, K.; Wang, Q. Copper-Catalyzed Aminoalkynylation of Alkenes with Hypervalent Iodine Reagents. Chem. Sci. 2017, 8, 8265-8270.

(21) Han, W.-J.; Wang, Y.-R.; Zhang, J.-W.; Chen, F.; Zhou, B.; Han, B. Cu-Catalyzed Oxyalkynylation and Aminoalkynylation of Unactivated Alkenes: Synthesis of Alkynyl-Featured Isoxazolines and Cyclic Nitrones. Org. Lett. 2018, 20, 29602963.

(22) Li, Y.; Lu, R.; Sun, S.; Liu, L. Metal-Free Three-Component Oxyalkynylation of Alkenes. Org. Lett. 2018, 20, 6836-6839.

(23) Jiang, H.; Studer, A. Transition-Metal-Free Three-Component Radical 1,2-Amidoalkynylation of Unactivated Alkenes. Chem. - Eur. J. 2019, 25, 516-520.

(24) Yang, X.; Tsui, G. C. Silver-Catalyzed Trifluoromethylalkynylation of Unactivated Alkenes with Hypervalent Iodine Reagents. Org. Lett. 2019, 21, 8625-8629.

(25) Hari, D. P.; Waser, J. Copper-Catalyzed Oxy-Alkynylation of Diazo Compounds with Hypervalent Iodine Reagents. J. Am. Chem. Soc. 2016, 138, 2190-2193.

(26) Hari, D. P.; Waser, J. Enantioselective Copper-Catalyzed Oxy-Alkynylation of Diazo Compounds. J. Am. Chem. Soc. 2017, 139, 8420-8423.

(27) Borrel, J.; Pisella, G.; Waser, J. Copper-Catalyzed Oxyalkynylation of $\mathrm{C}-\mathrm{S}$ Bonds in Thiiranes and Thiethanes with Hypervalent Iodine Reagents. Org. Lett. 2020, 22, 422-427.

(28) Boelke, A.; Finkbeiner, P.; Nachtsheim, B. J. Atom-Economical Group-Transfer Reactions with Hypervalent Iodine Compounds. Beilstein J. Org. Chem. 2018, 14, 1263-1280.

(29) Egami, H.; Shimizu, R.; Usui, Y.; Sodeoka, M. Oxy-Trifluoromethylation of Alkenes and Its Application to the Synthesis of $\beta$-Trifluoromethylstyrene Derivatives. J. Fluor. Chem. 2014, 167, 172-178.

(30) Bertho, S.; Rey-Rodriguez, R.; Colas, C.; Retailleau, P.; Gillaizeau, I. Regio- and Stereoselective Iron-Catalyzed Oxyazidation of Enamides Using a Hypervalent Iodine Reagent. Chem. - Eur. J. 2017, 23, 17674-17677.

(31) Banerjee, S.; Senthilkumar, B.; Patil, N. T. Gold-Catalyzed 1,2-Oxyalkynylation of N-Allenamides with Ethylnylbenziodoxolones. Org. Lett. 2019, 21, 180-184.
(48) Cohen, D. R.; Townsend, C. A. A Dual Role for a Polyketide Synthase in Dynemicin Enediyne and Anthraquinone Biosynthesis. Nat. Chem. 2017, 10, 231.

(49) Brice, J. L.; Meerdink, J. E.; Stahl, S. S. Formation of Enamides via Palladium(II)-Catalyzed Vinyl Transfer from Vinyl Ethers to Nitrogen Nucleophiles. Org. Lett. 2004, 6, $1845-1848$.

(50) Brand, J. P.; Chevalley, C.; Scopelliti, R.; Waser, J. Ethynyl Benziodoxolones for the Direct Alkynylation of Heterocycles: Structural Requirement, Improved Procedure for Pyrroles, and Insights into the Mechanism. Chem. - Eur. J. 2012, $18,5655-5666$. 
(51) Following previous reports, 2 is "boiled at $80^{\circ} \mathrm{C}$ in $\mathrm{MeCN}$ " the compound does not solubilise at this temperature even when increasing the volume of $\mathrm{MeCN}$. Recrystalisation from EtOAc:MeOH 2:1 or column chromatography could afford the compound in greater purity. .

(52) Huang, H.; Jia, K.; Chen, Y. Hypervalent Iodine Reagents Enable Chemoselective Deboronative/Decarboxylative Alkenylation by Photoredox Catalysis. Angew. Chem. Int. Ed. 2015, $54,1881-1884$

(53) Other solvents were also tested such as THF, Tol, DME, EtOAc or $\mathrm{MeCN}$, which were detrimental for the reactivitygiving lower yields.

(54) We suspect this low yield is as of the result of degradation upon purification.

(55) The N-Boc 3,4-dihydro-1(2H)-pyridine was also tested in the reaction condition this however led to a very complex mixture.

(56) 10ha and $10 \mathrm{hb}$ were obtained as an unseperable mixture Based on 1H NMR analysis, both compounds are spectulated to have been obtained as single diastereoisomers in cis configuration.
(57) Ochiai, M.; Ito, T.; Takahashi, H.; Nakanishi, A.; Toyonari, M.; Sueda, T.; Goto, S.; Shiro, M. Hypervalent (Tert-Butylperoxy)Iodanes Generate Iodine-Centered Radicals at Room Temperature in Solution: Oxidation and Deprotection of Benzyl and Allyl Ethers, and Evidence for Generation of $\alpha$-Oxy Carbon Radicals. J. Am. Chem. Soc. 1996, 118, 77167730.

(58) Zhdankin, V. V.; Krasutsky, A. P.; Kuehl, C. J.; Simonsen, A. J.; Woodward, J. K.; Mismash, B.; Bolz, J. T. Preparation, XRay Crystal Structure, and Chemistry of Stable AzidoiodinanesDerivatives of Benziodoxole. J. Am. Chem. Soc. 1996 118, 5192-5197.

(59) Barluenga, J.; Campos-Gómez, E.; Rodríguez, D.; GonzálezBobes, F.; González, J. M. New Iodination Reactions of Saturated Hydrocarbons. Angew. Chem. 2005, 117, 6001-6004.

(60) Le Vaillant, F.; Wodrich, M. D.; Waser, J. Room Temperature Decarboxylative Cyanation of Carboxylic Acids Using Photoredox Catalysis and Cyanobenziodoxolones: A Divergent Mechanism Compared to Alkynylation. Chem. Sci. 2017, 8, $1790-1800$ 


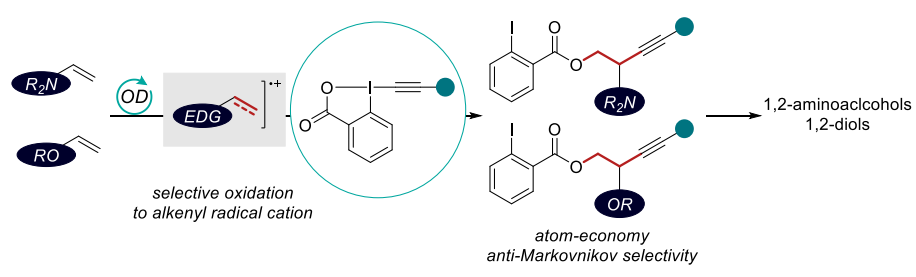

7 


\section{Supporting Information}

\section{Accessing 1,2-Amino Alcohols and Diols through Photocatalytic}

Anti-Markovnikov Difunctionalisation of Ene-Carbamates and Enol Ethers

Stephanie G. E. Amos, Stefano Nicolai, Jerome Waser*

Laboratory of Catalysis and Organic Synthesis, Institut des Sciences et Ingénierie Chimique, Ecole Polytechnique Fédérale de Lausanne, $\mathrm{CH}-1015$, Lausanne, Switzerland 


\section{Contents}

General methods

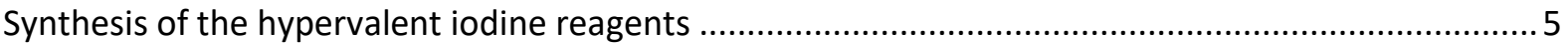

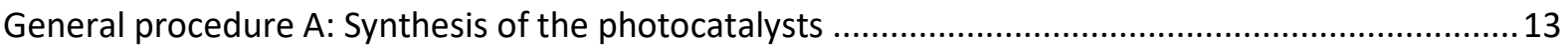

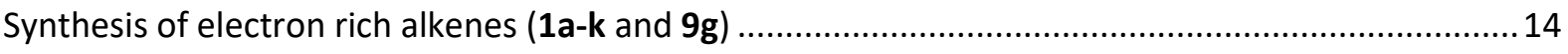

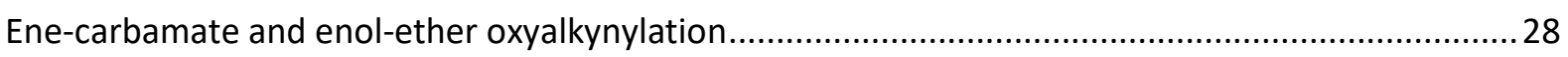

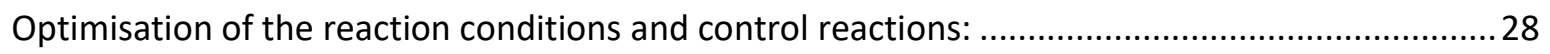

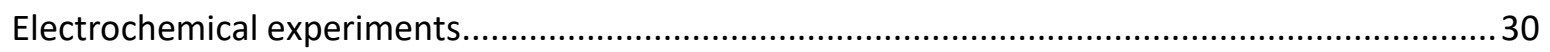

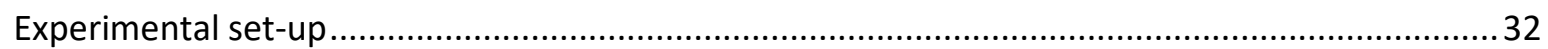

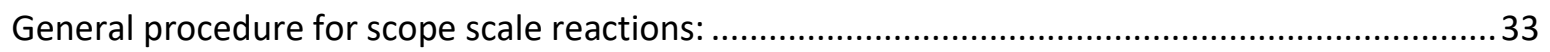

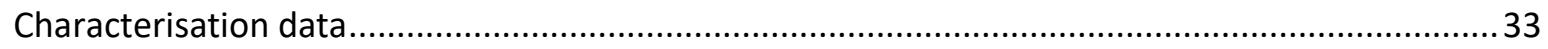

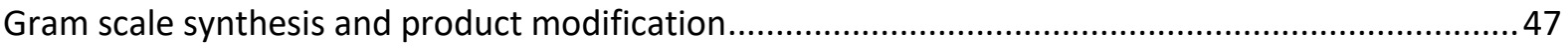

NMR spectra for synthesised alkenes and new compounds .........................................................5 50

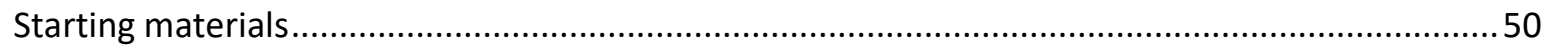

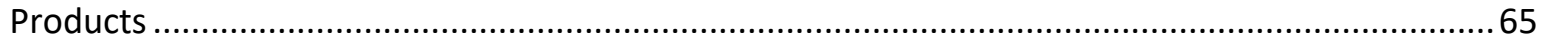




\section{General methods}

All reactions that were carried out in oven dried glassware and under an atmosphere of nitrogen is stated at the start of the reaction conditions. For flash chromatography, distilled technical grade solvents were used. THF, $\mathrm{CH}_{3} \mathrm{CN}$, toluene, $\mathrm{Et}_{2} \mathrm{O}$ and $\mathrm{CH}_{2} \mathrm{Cl}_{2}$ were dried by passage over activated alumina under nitrogen atmosphere $\left(\mathrm{H}_{2} \mathrm{O}\right.$ content $<10$ ppm, KarlFischer titration). The solvents were degassed by Freeze-Pump-Thaw method when mentioned. All chemicals were purchased from Acros, Aldrich, Fluka, VWR, TCl, Merck and used as such unless stated otherwise. Chromatographic purification was performed as flash chromatography using Macherey-Nagel silica 40-63, $60 \AA$, using the solvents indicated as eluent with 0.1-0.5 bar pressure. TLC was performed on Merck silica gel 60 F254 TLC glass plates and visualized with UV light and $p$-anisaldehyde stain (EtOH: $\mathrm{H}_{2} \mathrm{SO}_{4}: \mathrm{AcOH}: p$-anisaldehyde 135:5:1.5:3.7 V:V:V:V).

${ }^{1} \mathrm{H}$-NMR spectra were recorded on a Brucker DPX-400 $400 \mathrm{MHz}$ spectrometer in chloroform$d_{1}$ acetonitrile- $d_{3}$, DMSO- $d_{6}$ or acetone- $d_{6}$, all signals Are reported in ppm with the internal chloroform signal at $7.26 \mathrm{ppm}$, the internal acetonitrile signal at $1.94 \mathrm{ppm}$, the internal methanol signal at $3.30 \mathrm{ppm}$, the internal DMSO signal at $2.50 \mathrm{ppm}$ or the internal acetone signal at $2.05 \mathrm{ppm}$ as standard. The data is reported as ( $\mathrm{s}=$ singlet, $\mathrm{d}=$ doublet, $\mathrm{t}=$ triplet, $\mathrm{q}$ = quadruplet, $\mathrm{qi}=$ quintet, $\mathrm{m}=$ multiplet or unresolved, $\mathrm{br}=$ broad signal, $\mathrm{app}=$ apparent, coupling constant(s) in $\mathrm{Hz}$, integration, interpretation). ${ }^{13} \mathrm{C}-\mathrm{NMR}$ spectra were recorded with ${ }^{1} \mathrm{H}$-decoupling on a Brucker DPX-400 $100 \mathrm{MHz}$ spectrometer in chloroform- $d$, acetonitrile- $d^{3}$ $\mathrm{CD}_{3} \mathrm{OD}, \mathrm{DMSO}-d^{6}$ or acetone- $d^{6}$, all signals Are reported in ppm with the internal chloroform signal at $77.0 \mathrm{ppm}$, the internal acetonitrile signal at $1.3 \mathrm{ppm}$ the internal methanol signal at 49.0 ppm, the internal DMSO signal at 39.5 ppm or the internal acetone signals at 29.84 and 206.26 ppm as standard. Rotameric mixtures have been described at room temperature as a mixture of rotamers, only the split signals have been assigned to the major or minor rotamer. Regiomeric mixtures have been assigned based on the shift of the characteristic proton signals. Diastereoiomers have been separated when possible if not assigned based on ${ }^{1} \mathrm{H}$ NMR analysis.

Infrared spectra were recorded on a JASCO FT-IR B4100 spectrophotometer with an ATR PRO410-S and a ZnSe prisma and is reported in $\mathrm{cm}^{-1}$ ( $\mathrm{w}=$ weak, $\mathrm{m}=$ medium, $\mathrm{s}=$ strong, $\mathrm{br}$ $=$ broad).

High resolution mass spectrometric measurements were performed by the mass spectrometry service of ISIC at the EPFL on a MICROMASS (ESI) Q-TOF Ultima API.

All photoredox catalyzed reactions were carried out in oven dried glassware and under inert atmosphere (freeze pump thaw solvent stored on molecular sieves and under argon for maximum one week) unless specified otherwise. They were performed in test tubes (5 and 10 $\mathrm{mL}$ ) which were held using a rack for test tubes placed at the center of a crystallization dish or screw cap vials $(0.5-10 \mathrm{~mL})$ which were stuck to the base of the crystallization dish. In order to keep the temperature as constant as possible all reactions were ventilated by use of an over-head ventilator (desk fan). To the crystallization dish (a straight sided $15 \mathrm{~cm}$ diameter pyrex dish) were attached the blue LEDs (RUBAN LED 5MÈTRES - 60LED/M - 3528 BLEU - IP65 
with Transformateur pour Ruban LED 24W/2A/12V, bought directly on RubanLED.com). The distance between the LEDs and the test tubes was approximatively $3 \mathrm{~cm}$ for all vials and test tubes. Long irradiation resulted in temperature increasing up to $27{ }^{\circ} \mathrm{C}$ during overnight reactions. Photos have been provided.

UV/Vis spectroscopy was performed on an Agilent Cary 60 UV-Vis and steady-state luminescence spectroscopy was recorded on a Varian Cary Eclipse spectrophotometer. Cyclic voltammetry experiments were performed on a Biologic SP-150 Potentiostat, with a threeelectrode cell configuration: a glassy carbon electrode as the working electrode, $\mathrm{Pt}$ wire as a counter electrode and an $\mathrm{Ag} / \mathrm{AgCl}(\mathrm{KCl}, 3 \mathrm{M})$ electrode as the reference electrode. $\mathrm{Bu}_{4} \mathrm{NPF}_{6}$ was employed as the electrolyte $(0.1 \mathrm{M})$. 


\section{Synthesis of the hypervalent iodine reagents}

The synthesis of reagents $\mathbf{2}$, and $\mathbf{1 1 a - 1 1 f}$ had already been described before by our group. The procedures Are taken from the indicated publications to facilitate reproduction of the results by having all data in the same file.

1-Hydroxy-1,2-benziodoxol-3-(1H)-one (6)

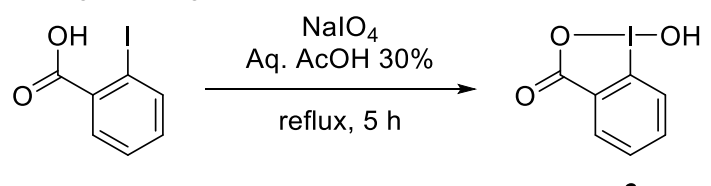

17

6

Following a reported procedure, ${ }^{1} \mathrm{NaIO}_{4}(40.5 \mathrm{~g}, 189 \mathrm{mmol}, 1.05$ equiv) and 2-iodobenzoic acid (17) (44.8 g, $180 \mathrm{mmol}, 1.0$ equiv) were suspended in $30 \%$ ( $v: \mathrm{v})$ aq. AcOH (350 mL). The mixture was vigorously stirred and refluxed for $5 \mathrm{~h}$. The reaction mixture was then diluted with cold water $(250 \mathrm{~mL})$ and allowed to cool to rt, protecting it from light. After $1 \mathrm{~h}$, the crude product was collected by filtration, washed on the filter with ice water $(3 \times 150 \mathrm{~mL})$ and acetone $(3 \times$ $150 \mathrm{~mL}$ ), and air-dried in the dark overnight to afford 1-Hydroxy-1,2-benziodoxol-3-(1H)-one (6) $(44.3 \mathrm{~g}, 168 \mathrm{mmol}, 93 \%$ yield) as a white solid.

${ }^{1}$ H NMR $\left(400 \mathrm{MHz}, \mathrm{DMSO}-d_{6}\right) \delta 8.02(\mathrm{dd}, J=7.7,1.4 \mathrm{~Hz}, 1 \mathrm{H}, \mathrm{ArH}), 7.97(\mathrm{~m}, 1 \mathrm{H}, \mathrm{ArH}), 7.85(\mathrm{dd}$, $J=8.2,0.7 \mathrm{~Hz}, 1 \mathrm{H}, \mathrm{ArH}), 7.71(\mathrm{td}, J=7.6,1.2 \mathrm{~Hz}, 1 \mathrm{H}, \operatorname{ArH}) .{ }^{13} \mathrm{C}$ NMR $\left(100 \mathrm{MHz}, \mathrm{DMSO}-d_{6}\right) \delta$ 167.7, 134.5, 131.5, 131.1, 130.4, 126.3, 120.4. Consistent with reported data. ${ }^{1}$

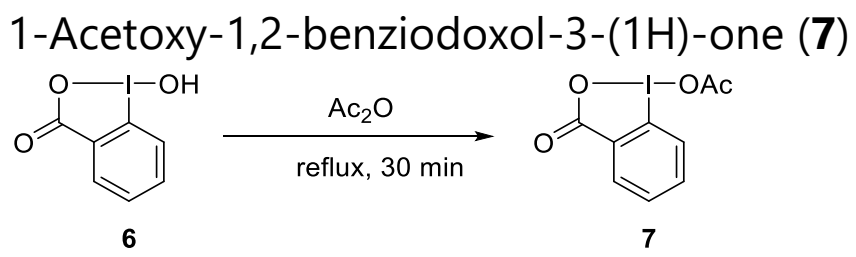

Following a reported procedure, ${ }^{2}$ compound 6 (3.00 g, $11.3 \mathrm{mmol}, 1.00$ equiv) was heated in $\mathrm{Ac}_{2} \mathrm{O}(10 \mathrm{~mL})$ to reflux until the solution turned clear (without suspension, ca. $30 \mathrm{~min}$ ). The mixture was then left to cool down and white crystals started to form. The crystallization was continued at $-18{ }^{\circ} \mathrm{C}$. The crystals were then collected and dried overnight under high vacuum to give compound 7 (3.06 $\mathrm{g}, 10.0 \mathrm{mmol}, 86 \%$ yield).

${ }^{1}$ H NMR $\left(400 \mathrm{MHz}\right.$, Chloroform- $\left.d_{3}\right) \delta 8.25(\mathrm{dd}, 1 \mathrm{H}, J=7.6,1.4 \mathrm{~Hz}, \operatorname{ArH}), 8.00(\mathrm{dd}, 1 \mathrm{H}, J=8.3$, $0.5 \mathrm{~Hz}, \operatorname{ArH}), 7.92(\mathrm{dt}, 1 \mathrm{H}, J=7.0,1.7 \mathrm{~Hz}, \operatorname{ArH}), 7.71(\mathrm{td}, 1 \mathrm{H}, J=7.6,0.9 \mathrm{~Hz}, \operatorname{ArH}), 2.25(\mathrm{~s}, 3 \mathrm{H}$, $\left.\mathrm{COCH}_{3}\right)$. NMR data correspond to the reported values. ${ }^{2}$

\footnotetext{
${ }^{1}$ Brand, J. P.; Chevalley, C.; Scopelliti, R.; Waser, J. Chem. Eur. J. 2012, 18, 5655.

2 Eisenberger, P.; Gischig, S.; Togni, A. Chem. Eur. J. 2006, 12, 2579.
} 


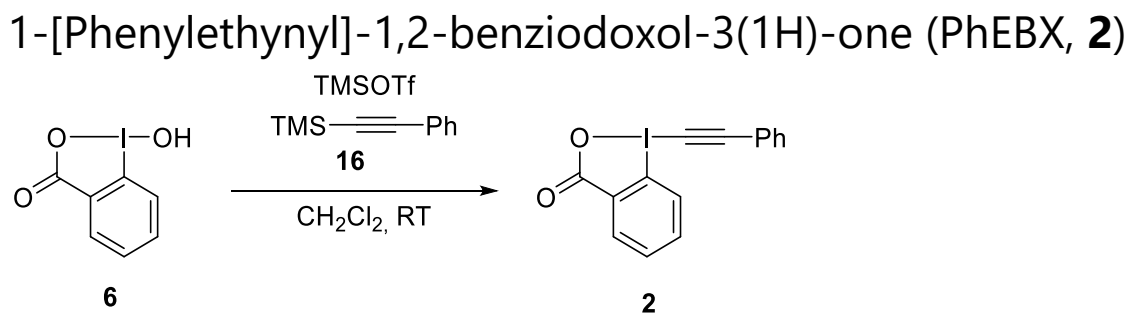

Following a reported procedure, ${ }^{1}$ trimethylsilyltriflate $(9.1 \mathrm{~mL}, 50 \mathrm{mmol}, 1.1$ equiv) was added dropwise to a suspension of 2-iodosylbenzoic acid (6) (12.1 g, $45.8 \mathrm{mmol}, 1.0$ equiv) in $\mathrm{CH}_{2} \mathrm{Cl}_{2}$ $(120 \mathrm{~mL})$ at $0{ }^{\circ} \mathrm{C}$. The mixture was stirred for $1 \mathrm{~h}$, followed by the dropwise addition of trimethyl(phenylethynyl)silane (16) $(8.8 \mathrm{~mL}, 50 \mathrm{mmol}, 1.1$ equiv) (slightly exothermic). The resulting suspension was stirred for $6 \mathrm{~h}$ at RT, during this time a white solid was formed. $\mathrm{A}$ saturated solution of $\mathrm{NaHCO}_{3}(120 \mathrm{~mL})$ was added and the mixture was stirred vigorously for $30 \mathrm{~min}$. The resulting suspension was filtered on a glass filter. The two layers of the mother liquors were separated and the organic layer was washed with sat. $\mathrm{NaHCO}_{3}(2 \times 50 \mathrm{~mL})$, dried over $\mathrm{MgSO}_{4}$, filtered and evaporated under reduced pressure. The resulting mixture was combined with the solid obtained by recrystallisation in EtOAc:MeOH $(2: 1$, ca. $28 \mathrm{~mL} / \mathrm{g})$. The mixture was cooled down, filtered and dried under high vacuum to afford Ph-EBX (2) $(6.8 \mathrm{~g}$, $25 \mathrm{mmol}, 43 \%$ yield) as colorless crystals.

Mp (Dec.) $155-160{ }^{\circ} \mathrm{C} .{ }^{1} \mathbf{H}$ NMR $(400 \mathrm{MHz}$, Chloroform-d) $\delta 8.46(\mathrm{~m}, 1 \mathrm{H}, \operatorname{ArH}), 8.28(\mathrm{~m}, 1 \mathrm{H}$, $\operatorname{ArH}), 7.80(\mathrm{~m}, 2 \mathrm{H}, \operatorname{ArH}), 7.63(\mathrm{~m}, 2 \mathrm{H}, \mathrm{ArH}), 7.48(\mathrm{~m}, 3 \mathrm{H}, \mathrm{ArH}) .{ }^{13} \mathrm{C}$ NMR $(101 \mathrm{MHz}$, Chloroformd) $\delta 163.9,134.9,132.9,132.5,131.6,131.3 .130 .8,128.8,126.2,120.5,116.2,106.6,50.2$. Consistent with reported data. ${ }^{1}$

1-[4-Trifluoromethylphenylethynyl]-1,2-benziodoxol-3(1H)-one (11a)<smiles>O=C1OI(O)c2ccccc21</smiles>

6<smiles>CSC#Cc1ccc(C(F)(F)F)cc1</smiles>

$17 \mathrm{a}$

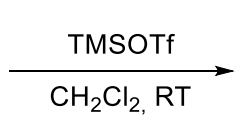<smiles>O=C1OI(C#Cc2ccc(C(F)(F)F)cc2)c2ccccc21</smiles>

11a

Following a reported procedure, ${ }^{3}$ trimethylsilyl triflate $(1.0 \mathrm{~mL}, 5.5 \mathrm{mmol}, 1.1$ equiv) was added to a suspension of 2-iodosylbenzoic acid (6) $\left(1.3 \mathrm{~g}, 5.0 \mathrm{mmol}, 1.0\right.$ equiv) in $\mathrm{CH}_{2} \mathrm{Cl}_{2}(15 \mathrm{~mL})$ at RT The resulting suspension was stirred for $1 \mathrm{~h}$, followed by the dropwise addition of trimethyl((4-(trifluoromethyl)phenyl)ethynyl)silane (17a) $(1.3 \mathrm{~mL}, 5.5 \mathrm{mmol}, 1.1$ equiv), which was dissolved in $\mathrm{CH}_{2} \mathrm{Cl}_{2}(1 \mathrm{~mL})$. The resulting suspension was stirred for $6 \mathrm{~h}$ at RT A saturated solution of $\mathrm{NaHCO}_{3}(20 \mathrm{~mL})$ was then added and the mixture was stirred vigorously for 30 min, the two layers were separated and the organic layer was washed with sat. $\mathrm{NaHCO}_{3}(20 \mathrm{~mL})$, dried over $\mathrm{MgSO}_{4}$, filtered and evaporated under reduced pressure. The resulting solid was boiled in $\mathrm{CH}_{3} \mathrm{CN}(20 \mathrm{~mL})$. The mixture was cooled down, filtered and dried under high vacuum to afford 11a (1.3 g, $3.2 \mathrm{mmol}, 64 \%$ yield) as a pale yellow solid.

\footnotetext{
${ }^{3}$ Lu, B.; Wu, J.; Yoshikai, N. J. Am. Chem. Soc. 2014, 136, 11598.
} 
${ }^{1} \mathbf{H}$ NMR (400 MHz, Chloroform- $\left.d\right) \delta 8.46-8.38(\mathrm{~m}, 1 \mathrm{H}, \mathrm{ArH}), 8.28-8.19(\mathrm{~m}, 1 \mathrm{H}, \mathrm{ArH}), 7.84-$ $7.74(\mathrm{~m}, 2 \mathrm{H}, \mathrm{ArH}), 7.74-7.65(\mathrm{~m}, 4 \mathrm{H}, \mathrm{ArH}) .{ }^{13} \mathrm{C}$ NMR $(101 \mathrm{MHz}$, Chloroform-d) $\delta$ 166.6, 135.0, 133.0, 132.6, $132.2(q, J=33.0 \mathrm{~Hz}), 131.7,131.2,126.3,125.7(q, J=3.6 \mathrm{~Hz}), 124.4,123.4(q, J=$ $272.6 \mathrm{~Hz}), 116.1,104.2,53.7$. Consistent with reported data. ${ }^{3}$

1-[4-Bromophenylethynyl]-1,2-benziodoxol-3(1H)-one (11 b)<smiles>O=C1OI(O)c2ccccc21</smiles>

6<smiles>CSC#Cc1ccc(Br)cc1</smiles>

$17 b$

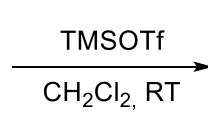<smiles>O=C1OI(C#Cc2ccc(Br)cc2)c2ccccc21</smiles>

$11 \mathrm{~b}$

Following a reported procedure, ${ }^{4}$ trimethylsilyl triflate $(1.0 \mathrm{~mL}, 5.5 \mathrm{mmol}, 1.1$ equiv) was added to a suspension of 2-iodosylbenzoic acid (6) $\left(1.3 \mathrm{~g}, 5.0 \mathrm{mmol}, 1.0\right.$ equiv) in $\mathrm{CH}_{2} \mathrm{Cl}_{2}(15 \mathrm{~mL})$ at RT The resulting suspension was stirred for $1 \mathrm{~h}$, followed by the dropwise addition of ( 4 bromophenyl)ethynyl)trimethylsilane (17b) (1.2 g, 5.5 mmol, 1.1 equiv), which was dissolved in $\mathrm{CH}_{2} \mathrm{Cl}_{2}(1 \mathrm{~mL})$. The resulting suspension was stirred for $6 \mathrm{~h}$ at RT A saturated solution of $\mathrm{NaHCO}_{3}(20 \mathrm{~mL})$ was then added and the mixture was stirred vigorously for $30 \mathrm{~min}$, the two layers were separated and the organic layer was washed with sat. $\mathrm{NaHCO}_{3}(20 \mathrm{~mL})$, dried over $\mathrm{MgSO}_{4}$, filtered and evaporated under reduced pressure. The resulting solid was boiled in $\mathrm{CH}_{3} \mathrm{CN}(20 \mathrm{~mL})$. The mixture was cooled down, filtered and dried under high vacuum to afford $11 \mathrm{~b}(1.4 \mathrm{~g}, 3.3 \mathrm{mmol}, 66 \%$ yield) as a pale yellow solid.

Mp 158- $163{ }^{\circ} \mathrm{C}$ (decomposition). ${ }^{1} \mathbf{H}$ NMR $(400 \mathrm{MHz}$, Chloroform-d) $\delta 8.51-8.30(\mathrm{~m}, 1 \mathrm{H}, \mathrm{Ar} H)$, $8.30-8.13(\mathrm{~m}, 1 \mathrm{H}, \operatorname{ArH}), 7.84-7.72(\mathrm{~m}, 2 \mathrm{H}, \operatorname{ArH}), 7.58(\mathrm{~d}, 2 \mathrm{H}, J=8.5 \mathrm{~Hz}, \operatorname{ArH}), 7.46(\mathrm{~d}, 2 \mathrm{H}, J=$ 8.5 Hz, ArH). ${ }^{13} \mathrm{C}$ NMR $(101 \mathrm{MHz}$, Chloroform-d) $\delta 166.6,135.1,134.3,132.7,132.3,131.9,131.4$, $126.3,125.7,119.6,116.3,105.4,52.1$. Consistent with reported data. ${ }^{6}$

\section{1-[2-Bromophenylethynyl]-1,2-benziodoxol-3(1H)-one (11c)}<smiles>O=C1OI(O)c2ccccc21</smiles>

6

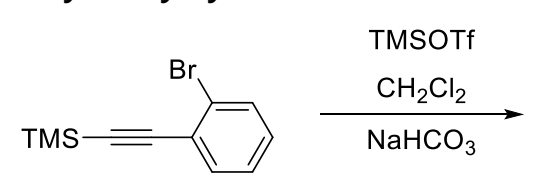

$17 \mathrm{c}$

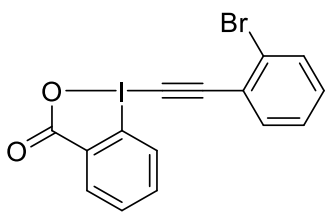

$11 \mathrm{c}$

Following a reported procedure, ${ }^{5}$ trimethylsilyl triflate $(1.0 \mathrm{~mL}, 5.5 \mathrm{mmol}, 1.1$ equiv) was added to a suspension of 2-iodosylbenzoic acid (6) $\left(1.32 \mathrm{~g}, 5.00 \mathrm{mmol}, 1.00\right.$ equiv) in $\mathrm{CH}_{2} \mathrm{Cl}_{2}(15 \mathrm{~mL})$ at RT The resulting suspension was stirred for $3 \mathrm{~h}$, followed by the drop wise addition of ((2bromophenyl)ethynyl)trimethylsilane (17c) $(1.17 \mathrm{~g}, 5.50 \mathrm{mmol}, 1.10$ equiv). The resulting suspension was stirred for $6 \mathrm{~h}$ at RT A saturated solution of $\mathrm{NaHCO}_{3}(20 \mathrm{~mL})$ was then added and the mixture was stirred vigorously for 30 minutes, the two layers were separated and the organic layer was washed with sat. $\mathrm{NaHCO}_{3}(20 \mathrm{~mL})$, dried over $\mathrm{MgSO}_{4}$, filtered and evaporated under reduced pressure. The resulting solid was boiled in $\mathrm{CH}_{3} \mathrm{CN}(20 \mathrm{~mL})$. The mixture was

\footnotetext{
4 Jia, K.; Zhang, F.; Huang, H.; Chen, Y. J. Am. Chem. Soc 2016, 138, 1514.

${ }^{5}$ Le Vaillant, F. ; Courant, T. ; Waser, J. Angew. Chem. Int. Ed. 2015, 54, 11200.
} 
cooled down, filtered and the collected solid was dried under high vacuum to afford 11c (1.50 g, $3.51 \mathrm{mmol}, 70 \%$ yield) as a colorless solid.

${ }^{1} \mathbf{H}$ NMR (400 MHz, Chloroform-d) $\delta 8.44(\mathrm{td}, J=7.3,2.1 \mathrm{~Hz}, 2 \mathrm{H}, \mathrm{ArH}), 7.84-7.74(\mathrm{~m}, 2 \mathrm{H}$, $\operatorname{ArH}), 7.68(\mathrm{~d}, J=1.1 \mathrm{~Hz}, 1 \mathrm{H}, \operatorname{ArH}), 7.61(\mathrm{dd}, J=7.6,1.7 \mathrm{~Hz}, 1 \mathrm{H}, A r H), 7.36(\mathrm{~m}, 2 \mathrm{H}, \operatorname{ArH}) .{ }^{13} \mathbf{C}$ NMR $(101 \mathrm{MHz} \text {, Chloroform-d) })^{7} \delta$ 166.6, 135.2, 134.7, 133.0, 132.7, 131.8, 131.3, 127.6, 126.8, $126.4,123.2,116.5,104.3,55.4$. Consistent with reported data. ${ }^{[6]}$

\section{1-[3-Fluorophenylethynyl]-1,2-benziodoxol-3(1H)-one (11d)}<smiles>O=C1OI(O)c2ccccc21</smiles>

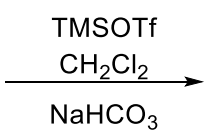

$17 d$

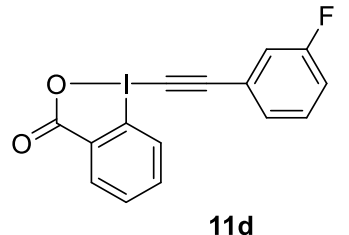

$11 \mathrm{~d}$

Following a reported procedure, ${ }^{6}$ trimethylsilyl triflate $(1.0 \mathrm{~mL}, 5.5 \mathrm{mmol}, 1.1$ equiv) was added to a suspension of 2-iodosylbenzoic acid (6) $\left(1.32 \mathrm{~g}, 5.00 \mathrm{mmol}, 1.00\right.$ equiv) in $\mathrm{CH}_{2} \mathrm{Cl}_{2}(15 \mathrm{~mL})$ at RT The resulting suspension was stirred for $1 \mathrm{~h}$, followed by the drop wise addition of ((3fluorophenyl)ethynyl)trimethylsilane (17d) $(1.1 \mathrm{~mL}, 5.5 \mathrm{mmol}, 1.1$ equiv). The resulting suspension was stirred for $6 \mathrm{~h}$ at RT A saturated solution of $\mathrm{NaHCO}_{3}(20 \mathrm{~mL})$ was then added and the mixture was stirred vigorously for 30 minutes, the two layers were separated and the organic layer was washed with sat. $\mathrm{NaHCO}_{3}(20 \mathrm{~mL})$, dried over $\mathrm{MgSO}_{4}$, filtered and evaporated under reduced pressure. The resulting solid was boiled in $\mathrm{CH}_{3} \mathrm{CN}(20 \mathrm{~mL})$. The mixture was cooled down, filtered and the collected solid was dried under high vacuum to afford 11d (787 $\mathrm{mg}, 2.15 \mathrm{mmol}, 43 \%$ yield) as a colorless solid.

${ }^{1}$ H NMR (400 MHz, DMSO- $\left.d_{6}\right) \delta 8.33(\mathrm{dd}, J=8.2,0.8 \mathrm{~Hz}, 1 \mathrm{H}, \mathrm{ArH}), 8.13(\mathrm{dd}, J=7.4,1.7 \mathrm{~Hz}, 1 \mathrm{H}$, $\operatorname{ArH}), 7.91(\mathrm{ddd}, J=8.2,7.2,1.7 \mathrm{~Hz}, 1 \mathrm{H}, \mathrm{ArH}), 7.81(\mathrm{td}, J=7.3,0.9 \mathrm{~Hz}, 1 \mathrm{H}, \operatorname{ArH}), 7.64-7.59(\mathrm{~m}$, $1 \mathrm{H}, \mathrm{ArH}), 7.58-7.53(\mathrm{~m}, 2 \mathrm{H}, \mathrm{ArH}), 7.47-7.37(\mathrm{~m}, 1 \mathrm{H}, \mathrm{ArH}) .{ }^{13} \mathrm{C}$ NMR $\left(101 \mathrm{MHz}, \mathrm{DMSO}-d_{6}\right)^{7}$ 166.3, $161.8(\mathrm{~d}, J=245.6 \mathrm{~Hz}), 135.3,131.9,131.3,131.2(\mathrm{~d}, J=8.7 \mathrm{~Hz}), 129.0(\mathrm{~d}, J=2.9 \mathrm{~Hz})$, 127.7, $122.4(\mathrm{~d}, J=9.6 \mathrm{~Hz}), 119.2(\mathrm{~d}, J=23.4 \mathrm{~Hz}), 118.1(\mathrm{~d}, J=21.1 \mathrm{~Hz}), 116.4,102.5(\mathrm{~d}, J=3.3$ $\mathrm{Hz})$, 53.8. ${ }^{19} \mathrm{~F}$ NMR $\left(376 \mathrm{MHz}, \mathrm{DMSO}-d_{6}\right) \delta$-111.7. Consistent with reported data. ${ }^{5}$

1-[4-Methylphenylethynyl]-1,2-benziodoxol-3(1H)-one (11e)<smiles>O=C1OI(O)c2ccccc21</smiles>

6

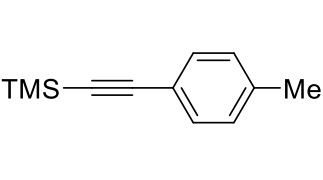

$17 \mathrm{e}$

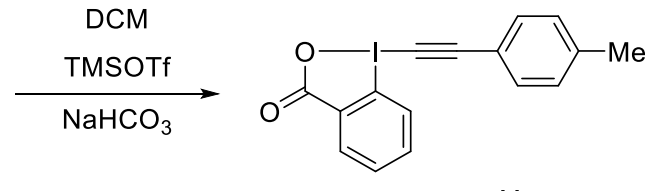

$11 \mathrm{e}$

Following a reported procedure, ${ }^{8}$ trimethylsilyl triflate $(1.0 \mathrm{~mL}, 5.5 \mathrm{mmol}, 1.1$ equiv) was added to a suspension of 2-iodosylbenzoic acid (6) $\left(1.32 \mathrm{~g}, 5.00 \mathrm{mmol}, 1.00\right.$ equiv) in $\mathrm{CH}_{2} \mathrm{Cl}_{2}(15 \mathrm{~mL})$ at room temperature. The resulting suspension was stirred for $3 h$, followed by the dropwise

\footnotetext{
${ }^{6}$ Le Vaillant, F. ; Garreau, M. ; Nicolai, S. ; Gryn'Ova, G. ; Corminboeuf, C. ; Waser, J. Chem. Sci. 2018, 9, 5883.

${ }^{7}$ One carbon is not resolved.

${ }^{8}$ Huang, H.; Zhang, G.; Gong, L.; Zhang, S.; Chen, Y. J. Am. Chem. Soc. 2014, 136, 2280.
} 
addition of trimethyl( $p$-tolylethynyl)silane (17e) $(1.04 \mathrm{~g}, 5.50 \mathrm{mmol}, 1.10$ equiv). The resulting suspension was stirred for $6 \mathrm{~h}$ at room temperature. A saturated solution of $\mathrm{NaHCO}_{3}(20 \mathrm{~mL})$ was then added and the mixture was stirred vigorously for 30 minutes, the two layers were separated and the organic layer was washed with saturated solution of $\mathrm{NaHCO}_{3}(20 \mathrm{~mL})$, dried over $\mathrm{MgSO}_{4}$, filtered and evaporated under reduced pressure. The resulting solid was boiled in $\mathrm{MeCN}$ (ca $20 \mathrm{~mL}$ ). The mixture was cooled down, filtered and dried under high vacuum to afford 11 e $(0.540 \mathrm{~g}, 1.49 \mathrm{mmol}, 30 \%$ yield $)$ as a white solid.

${ }^{1}$ H NMR (400 MHz, Chloroform-d): $\delta 8.43$ (dd, $\left.J=6.1,2.9 \mathrm{~Hz}, 1 \mathrm{H}, \operatorname{ArH}\right), 8.30-8.14(\mathrm{~m}, 1 \mathrm{H}, \operatorname{ArH})$, $7.77(\mathrm{dd}, J=6.9,3.1 \mathrm{~Hz}, 2 \mathrm{H}, \operatorname{ArH}), 7.50(\mathrm{~d}, J=7.8 \mathrm{~Hz}, 2 \mathrm{H}, \operatorname{ArH}), 7.25(\mathrm{~d}, J=7.6 \mathrm{~Hz}, 2 \mathrm{H}, \operatorname{ArH})$, $2.43\left(\mathrm{~s}, 3 \mathrm{H}, \mathrm{ArCH}_{3}\right) ;{ }^{13} \mathrm{C}$ NMR $(100 \mathrm{MHz}$, Chloroform-d): $\delta$ 166.6, 141.5, 134.9, 132.8, 132.5, $131.6,131.3,129.5,126.2,117.4,116.2,107.25,49.1,21.7$. The characterization data corresponded to the reported values. ${ }^{8}$

Triisopropylsilyl trimethylsilylacetylene (18)

Following a reported procedure, ${ }^{9} n$-butyllithium ( $2.5 \mathrm{M}$ in hexanes, $28 \mathrm{~mL}, 70 \mathrm{mmol}, 0.98$ equiv) was added dropwise to a stirred solution of ethynyltrimethylsilane (19) $(7.0 \mathrm{~g}, 71 \mathrm{mmol}, 1.0$ equiv) in THF $(100 \mathrm{~mL})$ at $-78{ }^{\circ} \mathrm{C}$. The mixture was warmed to $0{ }^{\circ} \mathrm{C}$ and stirred for $5 \mathrm{~min}$. The mixture was then cooled back to $-78{ }^{\circ} \mathrm{C}$ and chlorotriisopropylsilane $(15 \mathrm{~mL}, 71 \mathrm{mmol}, 1.0$ equiv) was added dropwise. The mixture was then allowed to warm to room temperature and stirred overnight. A saturated solution of ammonium chloride $(100 \mathrm{~mL})$ was added, and the reaction mixture was extracted with diethyl ether $(2 \times 100 \mathrm{~mL})$. The combined organic layers were washed with water and brine, then dried over MgSO4, filtered and concentrated under reduced pressure to obtain a colorless liquid which was further purified by filtration on silica eluting with pentane $(500 \mathrm{~mL})$ to yield $18(16 \mathrm{~g}, 64 \mathrm{mmol}, 90 \%$ yield) as a colorless liquid.

${ }^{1} \mathbf{H}$ NMR (400 MHz, Chloroform-d) $\delta 1.08$ (m, 21H, TIPS), 0.18 (s, 9H, TMS). Consistent with reported data. ${ }^{9}$

1-[(Triiso-propylsilyl)ethynyl]-1,2-benziodoxol-3(1H)-one (TIPS-EBX, 11f) ${ }^{10}$<smiles>O=C1OI(O)c2ccccc21</smiles>

6

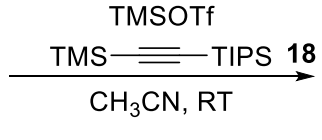<smiles>O=C1OI(C#C[In])c2ccccc21</smiles>

$11 f$

Following a reported procedure, ${ }^{11}$ 2-iodosylbenzoic acid (6) $(8.0 \mathrm{~g}, 30 \mathrm{mmol}, 1.0$ equiv) was charged in an oven-dried round-bottomed $250 \mathrm{~mL}$ flask equipped with a magnetic stirrer. The

\footnotetext{
${ }^{9}$ Helal, C. J.; Magriotis, P. A.; Corey, E. J. J. Am. Chem. Soc. 1996, 118, 10938.

${ }^{10}$ In this methodology TIPS-EBX (11f) was obtained using its previous synthetic strategy however recently we have developed a one-pot proceedure: Hari, D. P.; Caramenti, P.; Schouwey, L.; Chang, M.; Nicolai, S.; Bachert, D.; Wright, T.; Orella, C.; Jerome Waser, J. Org. Process Res. Dev. 2020, 24, 106.

${ }^{11}$ Brand, J. P.; Waser, J. Angew. Chem. Int. Ed. 2010, 49, 7304.
} 
solid was placed under a nitrogen atmosphere and anhydrous acetonitrile $(100 \mathrm{~mL})$ was added. The mixture was cooled to $0{ }^{\circ} \mathrm{C}$. Trimethylsilyltriflate $(6.0 \mathrm{~mL}, 33 \mathrm{mmol}, 1.1$ equiv) was added dropwise. After 15 min, (trimethylsilyl)(triisopropylsilyl)acetylene (18) (8.5 g, 33 mmol, 1.1 equiv) was added dropwise. After $30 \mathrm{~min}$, the suspension became an orange solution. Pyridine (2.7 $\mathrm{mL}, 33 \mathrm{mmol}, 1.1$ equiv) was added dropwise. After $15 \mathrm{~min}$, the reaction mixture was transferred in a one-neck $500 \mathrm{~mL}$ flask and concentrated under vacuum to afford a yellow solid. The solid was dissolved in $\mathrm{CH}_{2} \mathrm{Cl}_{2}(100 \mathrm{~mL})$ and transferred in a $500 \mathrm{~mL}$ separatory funnel. The organic layer was washed with a $1 \mathrm{M} \mathrm{HCl}$ solution $(50 \mathrm{~mL})$ and the aqueous layer was extracted with $\mathrm{CH}_{2} \mathrm{Cl}_{2}(100 \mathrm{~mL})$. The organic layers were combined, washed with a saturated solution of $\mathrm{NaHCO} 3(2 \times 100 \mathrm{~mL})$, dried over MgSO4, filtered and the solvent was evaporated under reduced pressure. Recrystallization from acetonitrile $(40 \mathrm{~mL})$ afforded TIPS-EBX (11f) $(9.2 \mathrm{~g}, 21.5 \mathrm{mmol}, 71 \%$ yield) as colorless crystals.

Mp (Dec.) 170-176 ${ }^{\circ} \mathrm{C} .{ }^{1} \mathbf{H}$ NMR $(400 \mathrm{MHz}$, Chloroform-d) $\delta 8.44(\mathrm{~m}, 1 \mathrm{H}, \mathrm{ArH}), 8.29(\mathrm{~m}, 1 \mathrm{H}$, $\mathrm{ArH}), 7.77(\mathrm{~m}, 2 \mathrm{H}, \mathrm{ArH}), 1.16$ (m, 21H, TIPS). ${ }^{13} \mathrm{C}$ NMR (100 MHz, Chloroform-d) $\delta 166.4,134.6$, 132.3, 131.4, 131.4, 126.1, 115.6, 114.1, 64.6, 18.4, 11.1. IR $\vee 2943(\mathrm{~m}), 2865(\mathrm{~m}), 1716(\mathrm{~m}), 1618$ $(\mathrm{m}), 1604(\mathrm{~s}), 1584(\mathrm{~m}), 1557(\mathrm{~m}), 1465(\mathrm{~m}), 1439(\mathrm{w}), 1349(\mathrm{~m}), 1291(\mathrm{~m}), 1270(\mathrm{w}), 1244(\mathrm{~m})$, $1140(\mathrm{~m}), 1016(\mathrm{~m}), 999(\mathrm{~m}), 883(\mathrm{~m}), 833(\mathrm{~m}), 742(\mathrm{~m}), 702(\mathrm{~s}), 636(\mathrm{~m})$. Consistent with reported data. ${ }^{11}$

\section{3-Bromopropyl 4-((trimethylsilyl)ethynyl)benzoate (20)}

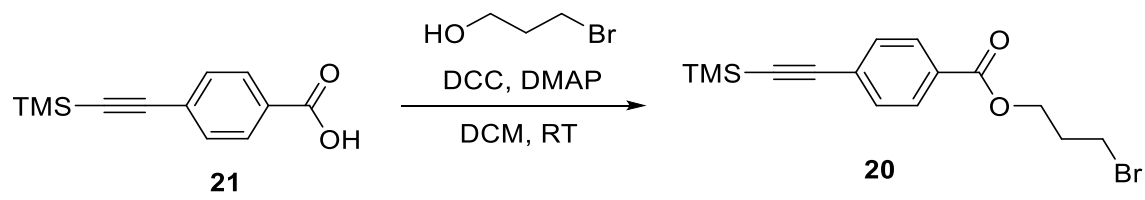

Following a reported procedure, ${ }^{12} 4$-(dimethylamino)-pyridine (67 mg, $0.55 \mathrm{mmol}, 12 \mathrm{~mol} \%$ ) was added to a stirred reaction mixture of 4-((trimethylsilyl)ethynyl)benzoic acid (21) $(1.0 \mathrm{~g}$, $4.6 \mathrm{mmol}, 1.0$ equiv), dicyclohexylcarbodiimide (1.0 g, $5.0 \mathrm{mmol}, 1.1$ equiv), 3-bromopropan1-ol ( $0.62 \mathrm{~mL}, 6.9 \mathrm{mmol}, 1.5$ equiv) in dry $\mathrm{CH}_{2} \mathrm{Cl}_{2}(15 \mathrm{~mL})$ at room temperature. The reaction mixture was filtered after $15 \mathrm{~h}$ and the solid was rinsed with dichloromethane $(2 \times 10 \mathrm{~mL})$. The combined filtrates were concentrated under vacuum. Purification by column chromatography pentane:ethyl acetate 9:1 afforded 3-bromopropyl 4-((trimethylsilyl)ethynyl)benzoate (20) (1.3 $\mathrm{g}, 3.8 \mathrm{mmol}, 82 \%$ yield) as a white solid.

'H NMR (400 MHz, Chloroform-d) $\delta 7.96(\mathrm{~d}, J=8.6 \mathrm{~Hz}, 2 \mathrm{H}, \operatorname{ArH}), 7.52(\mathrm{~d}, J=8.7 \mathrm{~Hz}, 2 \mathrm{H}, \operatorname{ArH})$, $4.46\left(\mathrm{t}, J=6.0 \mathrm{~Hz}, 2 \mathrm{H}, \mathrm{OCH}_{2}\right), 3.54\left(\mathrm{t}, J=6.6 \mathrm{~Hz}, 2 \mathrm{H}, \mathrm{BrCH}_{2}\right), 2.32\left(\mathrm{p}, J=6.4 \mathrm{~Hz}, 2 \mathrm{H}, \mathrm{CH}_{2} \mathrm{CH}_{2}\right)$, 0.26 (s, 9H, TMS). ${ }^{13} \mathrm{C}$ NMR (101 MHz, Chloroform-d) $\delta 165.8,131.9,129.5,129.4,127.9,104.0$, $97.9,62.9,31.8,29.4,-0.2$. The characterisation data corresponds to the reported literature values. $^{12}$

${ }^{12}$ Garreau, M.; Le Vaillant, F.; Waser, J. Angew. Chem. Int. Ed. 2019, 58, 8182. 
1-[(4-(3-Bromoprop-1-yl-benzoate)ethynyl]-1,2-benziodoxol-3(1H)-one (11 g)<smiles>CC(C)(C)OC(=O)c1ccc(C#CC(=O)OCCCBr)cc1</smiles>

Based on a reported procedure, ${ }^{12} 6(0.354 \mathrm{~g}, 1.34 \mathrm{mmol})$ was charged into a flame-dried 25 $\mathrm{mL}$ round bottomed flask equipped with a magnetic stirring bar and dry $\mathrm{CH}_{2} \mathrm{Cl}_{2}$ (Volume: 3.83 $\mathrm{mL}$ ) was added. To the later suspension, trimethylsilyl trifluoromethanesulfonate $(0.28 \mathrm{~mL}, 1.5$ $\mathrm{mmol}$ ) was added dropwise over a period of 20 min resulting in a yellowish suspension. The reaction was stirred for 1 hour, at that time, 3-bromopropyl 4-((trimethylsilyl)ethynyl)benzoate $(20,0.500 \mathrm{~g}, 1.47 \mathrm{mmol})$ was added portionwise. The suspension coloured grey. The reaction was then stirred 6 hours at room temperature. The reaction was quenched with sat. aq. $\mathrm{NaHCO}_{3}(3.5 \mathrm{~mL})$ and stirred for $2 \mathrm{~h}$ at $25^{\circ} \mathrm{C}$. A persistent emulsion was obtained, the solution was diluted with $50 \mathrm{~mL}$ of EtOAc and $20 \mathrm{~mL}$ of water. The organic layer was separated then washed with brine: $\mathrm{H}_{2} \mathrm{O}$ 1:1 (50 mL). The organic layer was concentrated to provide an orange crude oil and crude precipitate. The latter was recrystalised from MeCN (ca. $40 \mathrm{~mL}$ for $1.0 \mathrm{~g}$ of crude). $11 \mathrm{~g}$ ( $0.430 \mathrm{~g}, 0.838 \mathrm{mmol}, 63 \%$ yield) was obtained as an off-white partially crystalline solid.

Mp $(\mathrm{dec})=152{ }^{\circ} \mathrm{C} .{ }^{1} \mathbf{H}$ NMR $(400 \mathrm{MHz}$, Chloroform- $d) \delta 8.51-8.35(\mathrm{~m}, 1 \mathrm{H}, \mathrm{ArH}), 8.25(\mathrm{dd}, J=$ 7.5, $1.6 \mathrm{~Hz}, 1 \mathrm{H}, \mathrm{ArH}), 8.14-7.95(\mathrm{~m}, 2 \mathrm{H}, \mathrm{ArH}), 7.88-7.74(\mathrm{~m}, 2 \mathrm{H}, \operatorname{ArH}), 7.74-7.52(\mathrm{~m}, 2 \mathrm{H}, \operatorname{ArH})$, $4.51(\mathrm{t}, J=6.0 \mathrm{~Hz}, 2 \mathrm{H}, \mathrm{OCH}), 3.56\left(\mathrm{t}, J=6.5 \mathrm{~Hz}, 2 \mathrm{H}, \mathrm{CH}_{2} \mathrm{Br}\right), 2.35\left(\mathrm{p}_{\mathrm{app}}, J=6.3 \mathrm{~Hz}, 2 \mathrm{H}\right) .{ }^{13} \mathrm{C} \mathrm{NMR}$ (101 MHz, Chloroform-d) $\delta$ 166.5, 165.3, 135.1, 132.8, 132.6, 131.8, 131.6, 131.3, 129.8, 126.3, 125.1, 116.1, 105.0, 63.3, 54.1, 31.7, 29.2. IR $\left(\nu_{\text {max }} \mathrm{cm}^{-1}\right) 3017(\mathrm{~m}), 2987(\mathrm{~m}), 2971(\mathrm{~m}), 2912(\mathrm{~m})$, $2902(\mathrm{~m}), 2154(\mathrm{~m}), 1710(\mathrm{~m}), 1619(\mathrm{~s}), 1600(\mathrm{~s}), 1553(\mathrm{~m}), 1437(\mathrm{~m}), 1392(\mathrm{~m}), 1330(\mathrm{~s}), 1272$ (s), $1258(\mathrm{~s}), 1210(\mathrm{~m}), 1178(\mathrm{~m}), 1102(\mathrm{~s}), 1083$ (s), 1076 (s), $1016(\mathrm{~m})$. HRMS (ESI/QTOF) m/z: $[\mathrm{M}+\mathrm{H}]^{+}$Calcd for $\mathrm{C}_{19} \mathrm{H}_{14}{ }^{79} \mathrm{BrlO}_{4}{ }^{+}$512.9193; Found 512.9208 Calcd for $\mathrm{C}_{19} \mathrm{H}_{14}{ }^{81} \mathrm{BrlO}_{4}{ }^{+}$514.9195; Found 514.9191.

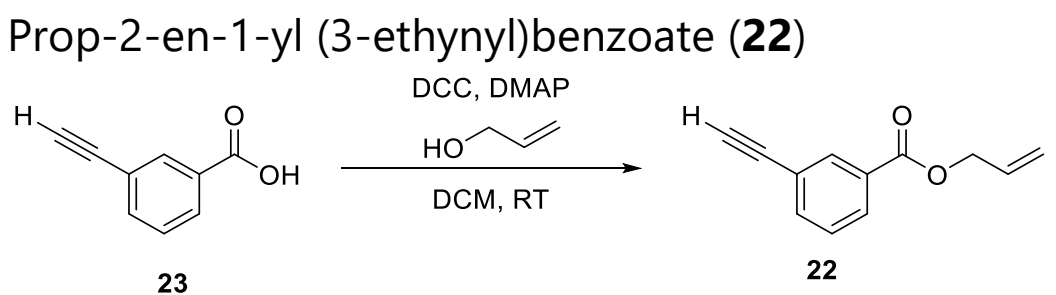

$\mathrm{N}, \mathrm{N}$-dimethylpyridin-4-amine $(0.050 \mathrm{~g}, 0.41 \mathrm{mmol})$ was added to a stirred reaction mixture of 3-ethynylbenzoic acid $(\mathbf{2 3}, 0.500 \mathrm{~g}, 3.42 \mathrm{mmol}), N, N^{\prime}$-methanediylidenedicyclohexanamine (0.777 g, $3.76 \mathrm{mmol})$ and prop-2-en-1-ol $(0.349 \mathrm{~mL}, 5.13 \mathrm{mmol})$ in dry $\mathrm{CH}_{2} \mathrm{Cl}_{2}(14 \mathrm{~mL})$ at RT The reaction mixture was filtered after $15 \mathrm{~h}$ and the solid was rinsed with dichloromethane (2 x $5 \mathrm{~mL}$ ). The combined filtrates were concentrated under vacuum. Purification by column chromatography with pentane:ethyl acetate 10:0 to 9:1 afforded prop-2-en-1-yl 3(ethynyl)benzoate $(\mathbf{2 2}, 0.570 \mathrm{~g}, 3.06 \mathrm{mmol}, 89 \%$ yield) as a colorless oil. 
${ }^{1} \mathbf{H}$ NMR $(400 \mathrm{MHz}$, Chloroform- $d) \delta 8.19(\mathrm{t}, J=1.7 \mathrm{~Hz}, 1 \mathrm{H}, \mathrm{ArH}), 8.04(\mathrm{dt}, J=7.9,1.5 \mathrm{~Hz}, 1 \mathrm{H}$, $\operatorname{ArH}), 7.67(\mathrm{dt}, J=7.7,1.5 \mathrm{~Hz}, 1 \mathrm{H}, \mathrm{ArH}), 7.41(\mathrm{t}, J=7.8 \mathrm{~Hz}, 1 \mathrm{H}, \operatorname{ArH}), 6.04(\mathrm{ddt}, J=17.2,10.4,5.7$ $\left.\mathrm{Hz}, 1 \mathrm{H}, \mathrm{CH}=\mathrm{CH}_{2}\right), 5.42\left(\mathrm{dq}, J=17.2,1.5 \mathrm{~Hz}, 1 \mathrm{H}, \mathrm{CH}=\mathrm{CH}_{2}\right), 5.30(\mathrm{dq}, J=10.5,1.3 \mathrm{~Hz}, 1 \mathrm{H}$, $\left.\mathrm{CH}=\mathrm{CH}_{2}\right), 4.83\left(\mathrm{dt}, J=5.7,1.4 \mathrm{~Hz}, 2 \mathrm{H}, \mathrm{CH}_{2}-\mathrm{CH}=\mathrm{CH}_{2}\right), 3.13(\mathrm{~s}, 1 \mathrm{H}$, aklynyl $H)$. Compound was used directly in next step with no further analysis.

1-[(3-(Prop-2-en-1-yl-benzoate)ethynyl]-1,2-benziodoxol-3(1H)-one (11h)<smiles>O=C1OI(O)c2ccccc21</smiles>

6

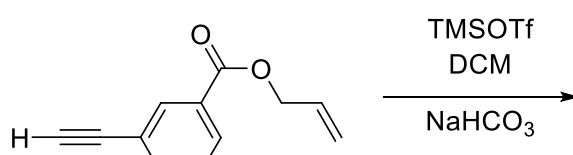

22

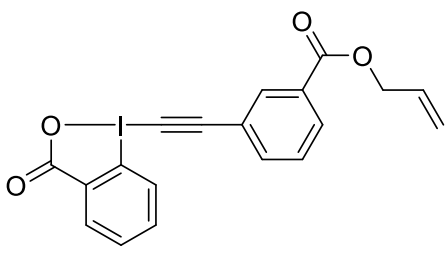

$11 \mathrm{~h}$

Based on a reported procedure, ${ }^{12}$ in an oven-dried $20 \mathrm{~mL}$ microwave vial equipped with a magnetic stirring bar, $6\left(0.500 \mathrm{~g}, 1.89 \mathrm{mmol}, 1.00\right.$ equiv) was suspended in dry $\mathrm{CH}_{2} \mathrm{Cl}_{2}(6 \mathrm{~mL}$, $0.31 \mathrm{M})$. To the later suspension, trimethylsilyl trifluoromethanesulfonate $(0.4 \mathrm{~mL}, 2 \mathrm{mmol}, 1.1$ equiv) was added dropwise over a period of $10 \mathrm{~min}$ resulting in a yellowish suspension. The reaction was stirred for 1 hour, at that time, allyl 3-ethynylbenzoate $(\mathbf{2 2}, 0.388 \mathrm{~g}, 2.08 \mathrm{mmol}$, 1.10 equiv) was added dropwise. The suspension coloured grey. The reaction was then stirred 18 hours at $40{ }^{\circ} \mathrm{C}$. The reaction was quenched with sat. aq. $\mathrm{NaHCO}_{3}(10 \mathrm{~mL})$ and stirred for 1 h. The layers were separated and the aqueous layer was back-extracted with $\mathrm{CH}_{2} \mathrm{Cl}_{2}(3 \times 7 \mathrm{~mL})$. The organic layers were combined, washed with brine: $\mathrm{H}_{2} \mathrm{O}(1: 1)$ dried over $\mathrm{Na}_{2} \mathrm{SO}_{4}$ and filtered. The total volume of $\mathrm{CH}_{2} \mathrm{Cl}_{2}$ was ca. $30 \mathrm{~mL}$. ca. $10 \mathrm{~mL}$ of heptane were added. $\mathrm{CH}_{2} \mathrm{Cl}_{2}$ was removed slowly under reduced pressure until solution clouded. The solution was then left to cool to RT then placed in fridge $\left(5^{\circ} \mathrm{C}\right)$ for $1 \mathrm{~h}$. At this time crystals had started to form. Crystalization proceeded at RT stirring the solution every $5 \mathrm{~min}$ with a spatula for $30 \mathrm{~min} . \mathbf{1 1 h}$ $(0.312 \mathrm{~g}, 0.722 \mathrm{mmol}, 38 \%$ yield) was obtained as an off-white slightly crystalline powder.

Mp (dec.) $=60{ }^{\circ} \mathrm{C} .{ }^{1} \mathbf{H}$ NMR $(400 \mathrm{MHz}$, Chloroform-d $) \delta 8.48-8.34(\mathrm{~m}, 1 \mathrm{H}, \mathrm{ArH}), 8.29(\mathrm{~d}, J=$ $1.8 \mathrm{~Hz}, 1 \mathrm{H}, \mathrm{ArH}), 8.29-8.21(\mathrm{~m}, 1 \mathrm{H}, \mathrm{ArH}), 8.17(\mathrm{dt}, J=7.9,1.5 \mathrm{~Hz}, 1 \mathrm{H}, \mathrm{ArH}), 7.85-7.72(\mathrm{~m}, 3 \mathrm{H}$, $\operatorname{ArH}), 7.54(\mathrm{t}, J=7.8 \mathrm{~Hz}, 1 \mathrm{H}, \mathrm{ArH}), 6.05\left(\mathrm{ddt}, J=17.3,10.4,5.7 \mathrm{~Hz}, 1 \mathrm{H}, \mathrm{CH}=\mathrm{CH}_{2}\right), 5.44(\mathrm{dq}, J=$ 17.2, $\left.1.5 \mathrm{~Hz}, 1 \mathrm{H}, \mathrm{CH}=\mathrm{CH}_{2}\right), 5.33\left(\mathrm{dq}, J=10.3,1.3 \mathrm{~Hz}, 1 \mathrm{H}, \mathrm{CH}=\mathrm{CH}_{2}\right), 4.86(\mathrm{dt}, J=5.7,1.4 \mathrm{~Hz}, 2 \mathrm{H}$, $\left.\mathrm{CH}_{2}-\mathrm{CH}=\mathrm{CH}_{2}\right) .{ }^{13} \mathrm{C}$ NMR $(101 \mathrm{MHz}$, Chloroform-d) $\delta$ 166.5, 165.0, 136.8, 135.1, 134.0, 132.6, $131.8,131.8,131.7,131.3,131.0,129.0,126.3,121.1,118.9,116.1,105.1,66.1,51.9$. IR $\left(V_{\max } \mathrm{cm}^{-}\right.$ 1) $2986(\mathrm{~s}), 2973(\mathrm{~s}), 2900(\mathrm{~s}), 2196(\mathrm{w}), 1717(\mathrm{~s}), 1599(\mathrm{~m}), 1407(\mathrm{~m}), 1271(\mathrm{~s}), 1241$ (s), $1066(\mathrm{~s})$. HRMS (ESI/QTOF) m/z: [M + H] ${ }^{+}$Calcd for $\mathrm{C}_{19} \mathrm{H}_{14} \mathrm{IO}_{4}{ }^{+} 432.9931$; Found 432.9934. 


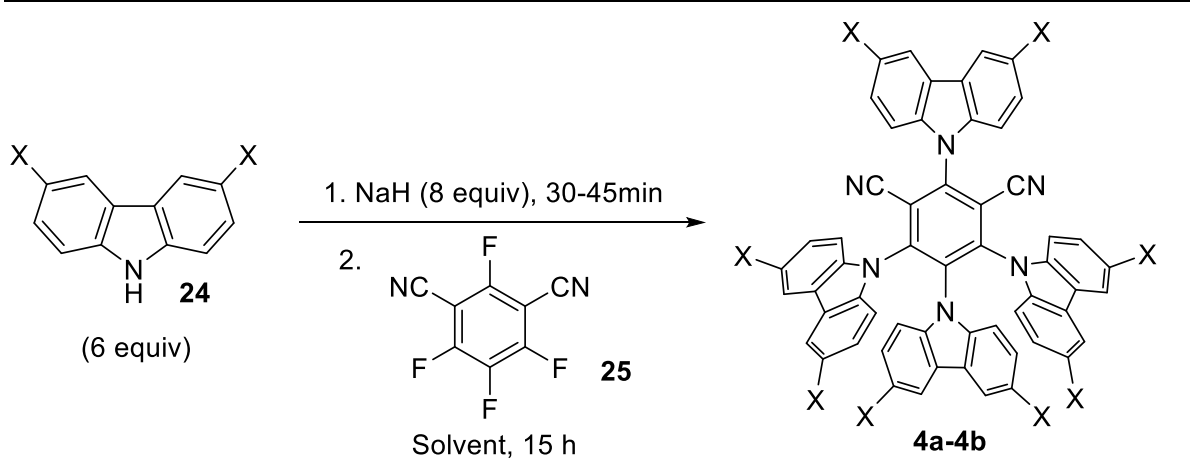

Sodium hydride (60\% suspension in mineral oil, 8.0 equiv) was added slowly to a stirred solution of substituted-carbazole 24 (5.0 equiv) in dry THF $(0.05 \mathrm{M})$ under a nitrogen atmosphere at RT After $30 \mathrm{~min}$, 2,4,5,6-tetrafluoroisophthalonitrile 25 (1.0 mmol, 1.0 equiv) was added. After stirring at RT for $15 \mathrm{~h}, 2 \mathrm{~mL}$ water was added to the reaction mixture to quench the excess of $\mathrm{NaH}$. The resulting mixture was then concentrated under reduced pressure. The crude product was purified by recrystallization from hexane: $\mathrm{CH}_{2} \mathrm{Cl}_{2}$ then filtered. The brown liquid filtrate was concentrated and recrystallized as before. The combined solids were then purified by column chromatography on silica gel with $\mathrm{CH}_{2} \mathrm{Cl}_{2}$ :Hexane.

\section{2,4,5,6-Tetra(9H-carbazol-9-yl)isophthalonitrile (4CzIPN, 4a)}

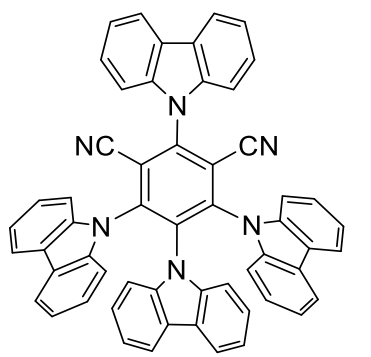

Following GP A and starting from $9 \mathrm{H}$-carbazole $24 \mathrm{a}(X=\mathrm{H}, 1.67 \mathrm{~g}$, $10.0 \mathrm{mmol}, 5.00$ equiv), sodium hydride $(0.60 \mathrm{~g}, 15 \mathrm{mmol}, 7.5$ equiv) and 2,4,5,6-tetrafluoroisophthalonitrile $25(0.40 \mathrm{~g}, 2.0 \mathrm{mmol})$ in 40 $\mathrm{mL}$ of THF. Recrystallization (Hexanes: $\mathrm{CH}_{2} \mathrm{Cl}_{2}(1: 1,90 \mathrm{~mL})$ ) afforded the crude product as a yellow powder. Column chromatography afforded 2,4,5,6-tetra(9H-carbazol-9-yl)isophthalonitrile (4a) as a bright yellow crystalline solid (1.14 g, $1.45 \mathrm{mmol}, 73$ \% yield).

Rf (Hexane; $\mathrm{CH}_{2} \mathrm{Cl}_{2}$ 1:1) $=0.29$. (yellow spot on TLC). ${ }^{1} \mathbf{H}$ NMR (400 MHz, Chloroform-d) $\delta 8.2(\mathrm{~d}, J=$ $7.7 \mathrm{~Hz}, 2 \mathrm{H}, \mathrm{ArH}), 7.8-7.6(\mathrm{~m}, 8 \mathrm{H}, \mathrm{ArH}), 7.5(\mathrm{ddd}, J=8.0,6.6,1.6 \mathrm{~Hz}, 2 \mathrm{H}, \operatorname{ArH}), 7.3(\mathrm{~d}, J=7.5 \mathrm{~Hz}, 2 \mathrm{H}$, $\operatorname{ArH}), 7.2(\mathrm{dd}, J=8.4,1.5 \mathrm{~Hz}, 4 \mathrm{H}, \mathrm{ArH}), 7.2-7.0(\mathrm{~m}, 8 \mathrm{H}, \mathrm{ArH}), 6.8(\mathrm{t}, J=7.8 \mathrm{~Hz}, 4 \mathrm{H}, \operatorname{ArH}), 6.6(\mathrm{td}, J=$ 7.6, $1.2 \mathrm{~Hz}, 2 \mathrm{H}, \mathrm{ArH}) .{ }^{13} \mathrm{C}$ NMR $(101 \mathrm{MHz}$, Chloroform-d) $\delta$ 145.2, 144.6, 140.0, 138.2, 136.9, 134.7, 127.0, 125.8, 124.9, 124.7, 124.5, 123.8, 122.4, 121.9, 121.4, 121.0, 120.4, 119.6, 116.3, 111.6, 109.9, 109.5, 109.4. ${ }^{1} \mathrm{H}$ NMR shift in Chloroform- $d$ are consistent with reported data. ${ }^{13}$

(2r,4s,5r)-2,4,5,6-Tetrakis(3,6-dichloro-9H-carbazol-9-yl)isophthalonitrile $(4 \mathrm{ClCZIPN}, \mathbf{4 b})$

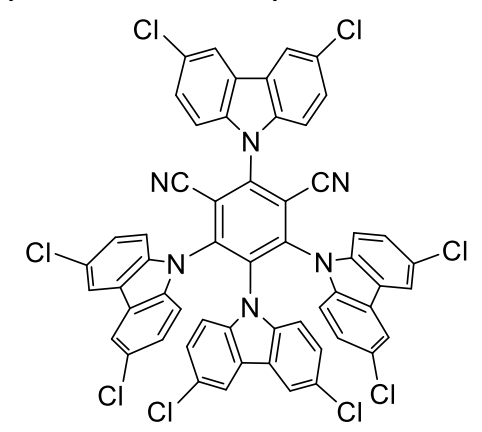

Following GP A and starting from 3,6-dichloro-9H-carbazole 24b $(1.96 \mathrm{~g}, 6.00 \mathrm{mmol}, 6.0$ equiv), sodium hydride $(320 \mathrm{mg}, 8.00 \mathrm{mmol}$, 8.0 equiv) and 2,4,5,6-tetrafluoroisophthalonitrile 25 ( $200 \mathrm{mg}, 1.00$ $\mathrm{mmol}$ ) in $20 \mathrm{~mL}$ of THF. Recrystallization (Hexanes: $\mathrm{CH}_{2} \mathrm{Cl}_{2}(1: 2,80$ $\mathrm{mL})$ ) gave $900 \mathrm{mg}$ of yellow powder, then second recrystallization gave $325 \mathrm{mg}$ of brown powder. Column chromatography of the combined solid afforded $(2 r, 4 s, 5 r)-2,4,5,6$-tetrakis(3,6-dichloro- $9 \mathrm{H}$ carbazol-9-yl)isophthalonitrile (4b) as a bright yellow crystalline solid (830 mg, $0.780 \mathrm{mmol}, 87 \%$ yield).

\footnotetext{
${ }^{13}$ Uoyama, H.; Goushi, K.; Shizu, K.; Nomura, H.; Adachi, C. Nature 2012, 492, 234.
} 
Rf (Hexane: $\mathrm{CH}_{2} \mathrm{Cl}_{2}$ 1:1): 0.25. (yellow spot on TLC). ${ }^{1} \mathbf{H}$ NMR $\left(400 \mathrm{MHz}\right.$, DMSO- $\left.d_{6}\right) \delta 8.60(\mathrm{~d}$, $J=2.1 \mathrm{~Hz}, 2 \mathrm{H}, \operatorname{ArH}), 8.15(\mathrm{~d}, J=2.1 \mathrm{~Hz}, 4 \mathrm{H}, \operatorname{ArH}), 8.08(\mathrm{~d}, J=8.8 \mathrm{~Hz}, 2 \mathrm{H}, \operatorname{ArH}), 7.87(\mathrm{dd}, J=$ 8.8, 2.1 Hz, 2H, ArH), $7.80(\mathrm{~d}, J=2.2 \mathrm{~Hz}, 2 \mathrm{H}, \operatorname{ArH}), 7.69(\mathrm{~d}, J=8.8 \mathrm{~Hz}, 4 \mathrm{H}, \operatorname{ArH}), 7.46(\mathrm{~d}, J=$ $8.8 \mathrm{~Hz}, 2 \mathrm{H}, \mathrm{ArH}), 7.32(\mathrm{dd}, J=8.8,2.2 \mathrm{~Hz}, 4 \mathrm{H}, \operatorname{ArH}), 6.93(\mathrm{dd}, J=8.8,2.2 \mathrm{~Hz}, 2 \mathrm{H}, \operatorname{ArH}) .{ }^{13} \mathrm{C}$ NMR $\left(101 \mathrm{MHz}, \mathrm{DMSO}-d_{6}\right) \delta 145.0,144.5,138.5,137.4,136.5,135.8,134.5,127.8,127.0$, $126.4,125.7,125.3,124.2,123.8,123.3,121.6,120.9,120.3,116.8,112.6,112.5,112.3,111.7$. HRMS (ESI) calcd for $\mathrm{C}_{56} \mathrm{H}_{24} \mathrm{Cl}_{8} \mathrm{~N}_{6}[\mathrm{M}+]$ 1059.9565; found 1059.9573.

\section{Synthesis of electron rich alkenes (1a-k and $9 g)$}

General note on commercial alkenes:

$N$-vinyl pyrrolidinone (sodium hydroxide as inhibitor) (1x) and 2-chloroethyl vinyl ether (triethanolamine as stabiliser) (9d) were purchased from Sigma Aldrich. $n$ Butyl vinyl ether (9a) and 3,4-dihydro-2H-pyran (9g) were purchased from Acros. ((Vinyloxy)methyl benzene (9b) and 2-ethoxy prop-1-ene (9f) were purchased from Fluorochem. Allyl vinyl ether (9c) was purchased from abcr. Cyclohexyl vinyl ether (stabilized with $\mathrm{KOH}$ ) (9e) was purchased from $\mathrm{TCl}$. All commercial alkenes were filtered over basic alumina before use and were used within 15 min without direct light exposition.

General note on synthesised alkenes:

All alkenes were used within 6 months of synthesis, stored at $4{ }^{\circ} \mathrm{C}$ and hidden from light. Some degradation (coloration) could be observed although it was not detrimental for the reaction yield.

\section{$N$-vinyloxazolidin-2-one (1a)}

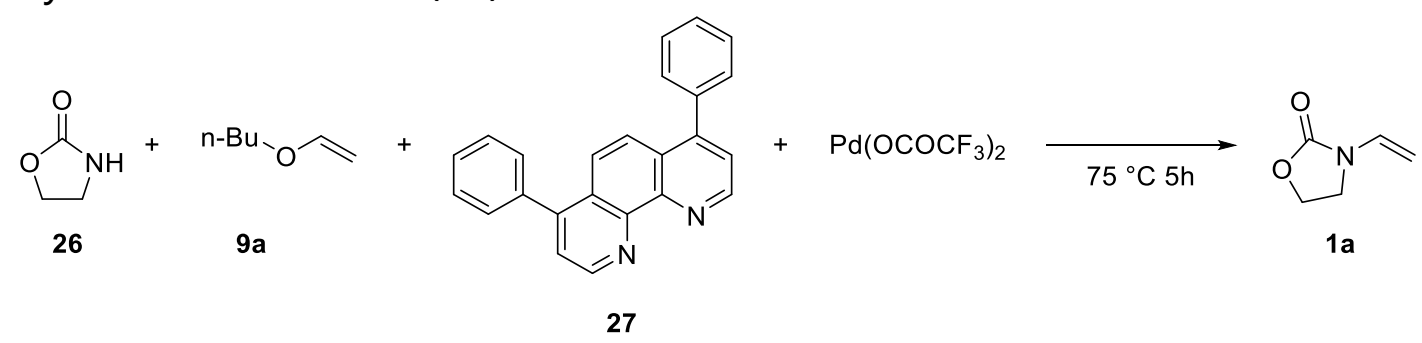

Following a modified reported procedure, ${ }^{14}$ in a $25 \mathrm{~mL}$ round bottomed flask equipped with magnetic stirrer, bathophenanthroline $\left(\mathbf{2 7}, 0.015 \mathrm{~g}, 0.045 \mathrm{mmol}, 0.05\right.$ equiv), $\mathrm{Pd}\left(\mathrm{OCOCF}_{3}\right)_{2}$ ( 0.015 g. $0.045 \mathrm{mmol}, 0.05$ equiv) and oxazolidinone (26, $0.077 \mathrm{~g} 0.904 \mathrm{mmol}, 1.0$ equiv) were dissolved in nbutyl vinyl ether $(9 a, 1.0 \mathrm{~mL}, 7.8 \mathrm{mmol}, 8.6$ equiv). The flask was closed with a septum and then opened to the atmosphere by means of a needle $(1.2 \times 40 \mathrm{~mm})$. The yellow suspension was then stirred at $75{ }^{\circ} \mathrm{C}$ for 2 hours. At this time, the mixture cooled down to room temperature. With no further treatment, the crude oil was then submitted directly to

\footnotetext{
${ }^{14}$ Brice, J. L.; Meerdink, J. E.; Stahl, S. S. Org. Lett. 2004, 6, 1845-1848.
} 
column chromatography ( $\mathrm{SiO}_{2}$; Pent:EtOAc $98: 2$ to $\left.8: 2\right)^{15}$ affording 1a as a colorless oil $(0.095$ g, $0.84 \mathrm{mmol}, 92 \%$ yield).

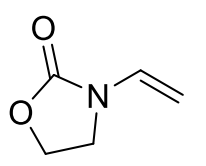

${ }^{1} \mathbf{H}$ NMR (400 MHz, Chloroform-d) $\delta 6.88\left(\mathrm{dd}, J=15.8,9.0 \mathrm{~Hz}, 1 \mathrm{H}, \mathrm{NCH}=\mathrm{CH}_{2}\right), 4.51$ $-4.38\left(\mathrm{~m}, 3 \mathrm{H}\right.$, cyclic $\left.-\mathrm{CH}_{2}+\mathrm{CH}=\mathrm{CH}_{2}\right), 4.29\left(\mathrm{dd}, J=15.8,1.3 \mathrm{~Hz}, 1 \mathrm{H}, \mathrm{NCH}=\mathrm{CH}_{2}\right), 3.79$ - $3.64\left(\mathrm{~m}, 2 \mathrm{H}\right.$, cyclic- $\left.\mathrm{CH}_{2}\right)$. The values of the ${ }^{1} \mathrm{H}$ NMR spectrum are in accordance with reported literature data. ${ }^{14}$

Tert-butyl phenethyl(vinyl)carbamate (1 $\mathbf{b})$

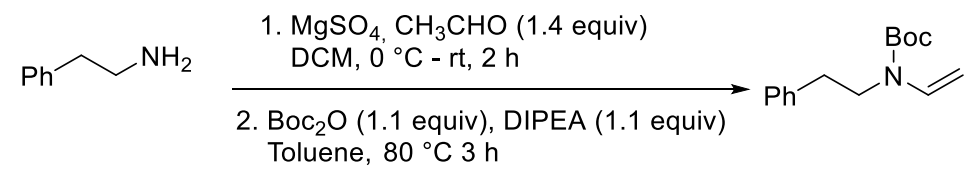

$1 \mathrm{~b}$

A flame-dried, $50 \mathrm{~mL}$ round-bottomed, two-necked flask was charged with anhydrous $\mathrm{MgSO}_{4}$ (stored in the glove box; $4.5 \mathrm{~g}$ ), closed, evacuated, and backfilled with nitrogen. $\mathrm{CH}_{2} \mathrm{Cl}_{2}$ (dry; 10 $\mathrm{mL}$ ) was added followed by 2-phenylethanamine $(\mathbf{2 8}, 1.3 \mathrm{~mL}, 10 \mathrm{mmol}, 1.0$ equiv). The resulting suspension was cooled down to $0{ }^{\circ} \mathrm{C}$ (ice/water bath). Acetaldehyde $(0.80 \mathrm{~mL}, 14 \mathrm{mmol}, 1.4$ equiv) was then added. The mixture was stirred and allowed to warm to room temperature over a period of 1 hour, and then stirred at room temperature for one additional hour. The solids were then removed through rapid filtration. $\mathrm{CH}_{2} \mathrm{Cl}_{2}$ was then distilled off $\left(1 \mathrm{~atm}, 50{ }^{\circ} \mathrm{C}\right)$. To the crude imine was added a solution of di-tert-butyl dicarbonate $(2.40 \mathrm{~g}, 11.0 \mathrm{mmol}, 1.1$ equiv) in toluene (dry; $5.0 \mathrm{~mL}$ ), followed by DIPEA (freshly distilled over $\mathrm{KOH} ; 1.8 \mathrm{~mL}, 11 \mathrm{mmol}$, 1.1 equiv). The resulting yellow solution was stirred at $70{ }^{\circ} \mathrm{C}$ for 3 hours. The reaction was stopped and the volatiles were removed under reduced pressure. The resulting crude yelloworange oil was submitted to column chromatography (Biotage, $40 \mathrm{~g} \mathrm{SiO}_{2}$; EtOAc in pentane, 0 to $8 \%$ ). The desired product was obtained as a mixture with unreacted $\mathrm{Boc}_{2} \mathrm{O}$. The excess $\mathrm{Boc}_{2} \mathrm{O}$ was removed as following: the eluate was dissolved in $\mathrm{EtOH}(5 \mathrm{~mL})$ and imidazole $(300 \mathrm{mg})$ and DMAP (54.0 mg, 0.1 eq compared to imidazole) were added. The resulting mixture was stirred at room temperature for 10 minutes. It was then concentrated under reduced pressure. The crude oil was submitted to column chromatography (Biotage, $24 \mathrm{~g} \mathrm{SiO}_{2}$; EtOAc in pentane, 0 to $10 \%)$ to furnish pure tert-butyl phenethyl(vinyl)carbamate $\mathbf{1 b}$ as a pale yellow oil $(0.607 \mathrm{~g}$, $2.45 \mathrm{mmol}, 25 \%$ yield).

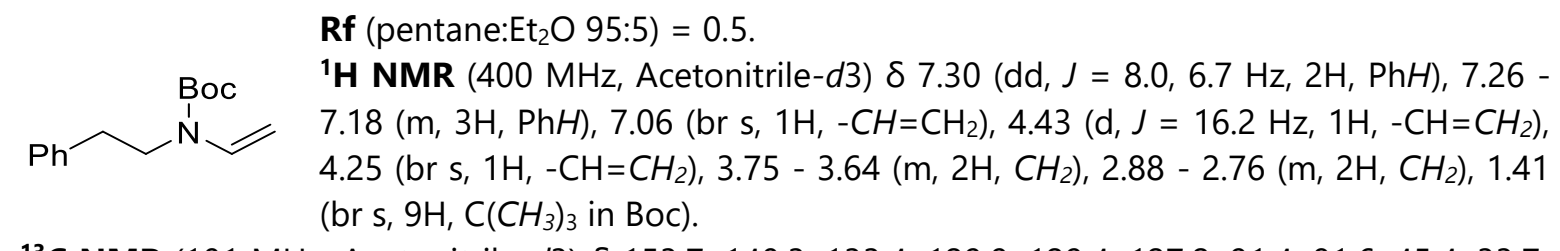

${ }^{13}$ C NMR $(101 \mathrm{MHz}$, Acetonitrile-d3) $\delta 153.7,140.3,133.4,129.9,129.4,127.2,91.4,81.6,45.4,33.7$, 28.2. IR $\left(\nu_{\text {max }} \mathrm{cm}^{-1}\right) 3372(\mathrm{~m}), 2969(\mathrm{~m}), 2924(\mathrm{~m}), 2880(\mathrm{~m}), 1704(\mathrm{w}), 1614(\mathrm{~m}), 1595(\mathrm{~s}), 1557(\mathrm{~m})$, $1493(\mathrm{~m}), 1352(\mathrm{~s}), 1148(\mathrm{~s}), 1231(\mathrm{~m}), 1052(\mathrm{~m}), 880(\mathrm{~m}), 828(\mathrm{~m}), 765(\mathrm{~m}), 745(\mathrm{~s}), 694(\mathrm{~m})$. HRMS (ESI/QTOF) $\mathrm{m} / \mathrm{z}:[\mathrm{M}+\mathrm{Na}]^{+}$Calcd for $\mathrm{C}_{15} \mathrm{H}_{21} \mathrm{NNaO}_{2}{ }^{+} 270.1464$; Found 270.1464.

\footnotetext{
${ }^{15}$ Pentane:EtOAc 95:5 needs to be run for at least 5 column volumes due to remove all the excess butyl vinyl ether.
} 


\section{Benzyl phenethyl(vinyl)carbamate (1c)}

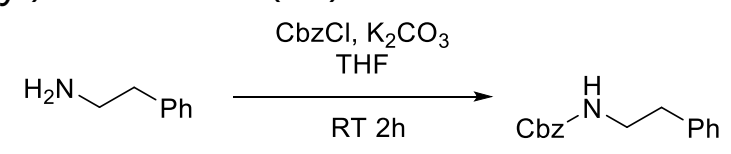

28

29

To a flame dried flask and under argon, 2-phenethylamine $(4.0 \mathrm{~mL}, 32 \mathrm{mmol}, 1$ eq.) and powered $\mathrm{K}_{2} \mathrm{CO}_{3}$ were suspended in anhydrous THF $(125 \mathrm{~mL}, 0.25 \mathrm{M})$. Benzyl chloroformate (5.0 $\mathrm{mL}, 35 \mathrm{mmol}, 1.1$ eq.) was added dropwise to the suspension. The reaction was stirred at room temperature for $2 \mathrm{~h}$. The solution was quenched with sat. aq. $\mathrm{NaHCO}_{3}(40 \mathrm{~mL})$ and the product was extracted with $\mathrm{CH}_{2} \mathrm{Cl}_{2}(3 \times 30 \mathrm{~mL})$. The combined organic layers were washed with sat. aq. $\mathrm{NaHCO}_{3}(2 \times 40 \mathrm{~mL})$, dried over $\mathrm{Na}_{2} \mathrm{SO}_{4}$ and filtered. The solvent was removed under reduced pressure and the crude oil was purified by flash chromatography $\left(\mathrm{SiO}_{2}\right.$, Pentane : EtOAc $\left.1: 4\right)$ affording pure benzyl phenethylcarbamate $(8.0 \mathrm{~g}, 31 \mathrm{mmol}, 99 \%$ yield). The compound was used directly in next step.

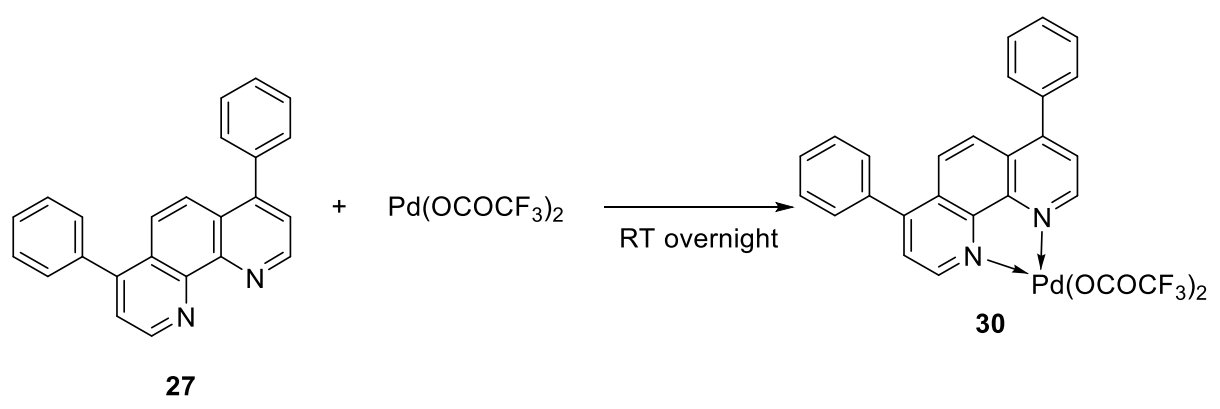

In a $25 \mathrm{~mL}$ flask palladium trifluoroacetate $(0.415 \mathrm{~g}, 1.21 \mathrm{mmol})$ was dissolved in MeCN (29.9 $\mathrm{mL}$ ). The flask was put under nitrogen and stirred at RT. A solution of 4,7-diphenyl-1,10phenanthroline (27, $0.402 \mathrm{~g}, 1.21 \mathrm{mmol}$ ) in $\mathrm{CH}_{2} \mathrm{Cl}_{2}$ (Ratio: 1.000 , Volume: $14.95 \mathrm{~mL}$ ) was added. The dark brown solution was stirred overnight.

$\mathrm{n}$-Hexane was added slowly under vigorous stirring (ca. $40 \mathrm{~mL}$ ). The mixture was left to precipitate slowly over $30 \mathrm{~min}$ at $\mathrm{rt}$. The suspension was cooled to $0{ }^{\circ} \mathrm{C}$ with an ice bath and the reaction was filtered and washed with pentane. $0.100 \mathrm{~g}$ of yellow complex was recovered. The filtrate was concentrated under reduced pressure, redisoved in a minimum of DCM (ca. 5 $\mathrm{mL}$ ) and precipitated out with $\mathrm{n}$-hexane. the suspension was cooled to $0{ }^{\circ} \mathrm{C}$ with an ice bath and was filtered a second time affording $0.563 \mathrm{~g}$ of yellow complex. The two batches were further dried on the high vaccum affording BphenPd $\left(\mathrm{O}_{2} \mathrm{C}_{2} \mathrm{~F}_{3}\right)_{2}(\mathbf{3 0}, 0.595 \mathrm{~g}, 0.895 \mathrm{mmol}, 73.9$ $\%$ yield) ( 0.095 of first batch and $0.500 \mathrm{~g}$ of second batch). This complexation is quite sensitive to scale and the purity of the palladium and phenathroline these compounds were purchased from Acros and were used with no further purification. Yields were variable between different bottles of the same supplier. Hexane proved more efficient than pentane for the precipitation, but in some cases precipitation was not observed and couldn't be induced. 
${ }^{1} \mathbf{H}$ NMR $\left(400 \mathrm{MHz}\right.$, DMSO- $\left.d_{6}\right) \delta 8.48(\mathrm{~s}, 2 \mathrm{H}), 8.27-8.04(\mathrm{~m}, 4 \mathrm{H}), 7.69(\mathrm{~s}, 10 \mathrm{H}) .{ }^{19} \mathbf{F}$ NMR $(376$ $\left.\mathrm{MHz}, \mathrm{DMSO}-d_{6}\right) \delta-73.3$. The ${ }^{1} \mathrm{H}$ NMR data corresponds to the reported literature data. ${ }^{16}$

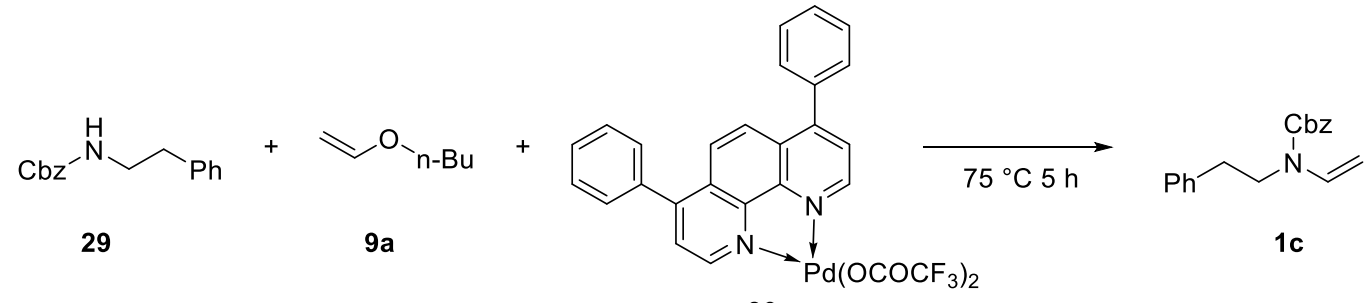

30

A $5 \mathrm{~mL}$ round-bottomed test tube was charged with BphenPd $\left(\mathrm{O}_{2} \mathrm{CCF}_{3}\right)_{2}(\mathbf{3 0}, 39.0 \mathrm{mg}, 0.0590$ mmol, $7.5 \mathrm{~mol} \%)$. $n$ Butyl vinyl ether (9a, $1.2 \mathrm{~mL}, 9.4 \mathrm{mmol}, 12$ equiv) was added, followed by benzyl phenethylcarbamate $(0.200 \mathrm{~g}, 0.783 \mathrm{mmol}, 1.0$ equiv). The vial was sealed with a PTFE septum, which was then pierced with a needle (gauge 18 - "pink needle") in order to ensure exposure to air. The resulting brown-orange suspension was stirred at $80^{\circ} \mathrm{C}$ for 3 hours. After this time, TLC analysis showed complete conversion of the starting material. The reaction mixture was then allowed to cool down to room temperature and was subsequently submitted to column chromatography (Biotage, $25 \mathrm{~g} \mathrm{SiO}_{2}$; EtOAc in pentane, 2 to $20 \%-3 \mathrm{CV}$ used to elute the butyl vinyl ether off). Pure benzyl phenethyl(vinyl)carbamate $1 \mathrm{c}(0.160 \mathrm{~g}, 0.569 \mathrm{mmol}$, $73 \%$ yield) was obtained as a colorless oil.

Rf (pentane :EtOAc $9: 1)$ 0.60. ${ }^{1} \mathbf{H}$ NMR $\left(400 \mathrm{MHz}\right.$, Acetonitrile- $\left.d_{3}\right) \delta 7.43$ -<smiles>C=CN(CCc1ccccc1)C(=O)OCc1ccccc1</smiles$7.31(\mathrm{~m}, 5 \mathrm{H}, \mathrm{PhH}), 7.27(\mathrm{~d}, J=7.1 \mathrm{~Hz}, 3 \mathrm{H}, \mathrm{PhH}), 7.24-7.15(\mathrm{~m}, 2 \mathrm{H}, \mathrm{PhH}), 7.08$ (dd, $\left.J=16.0,9.4 \mathrm{~Hz}, 1 \mathrm{H},-\mathrm{CH}=\mathrm{CH}_{2}\right), 5.09\left(\mathrm{br} \mathrm{s}, 2 \mathrm{H}, \mathrm{PhCH}_{2} \mathrm{O}\right), 4.52(\mathrm{~d}, J=16.1$ $\left.\mathrm{Hz}, 1 \mathrm{H},-\mathrm{CH}=\mathrm{CH}_{2}\right), 4.32\left(\right.$ br s, $\left.1 \mathrm{H},-\mathrm{CH}=\mathrm{CH}_{2}\right), 3.75\left(\mathrm{t}, J=7.7 \mathrm{~Hz}, 2 \mathrm{H}, \mathrm{CH}_{2} \mathrm{CH}_{2}\right)$, $2.84\left(\mathrm{dd}, J=8.8,6.6 \mathrm{~Hz}, 2 \mathrm{H}, \mathrm{CH}_{2} \mathrm{CH}_{2}\right)$.

${ }^{13} \mathrm{C}$ NMR (101 MHz, Acetonitrile- $d_{3,} 2$ carbons are not resolved) $\delta 154.2,140.0,137.6,133.4,129.8$, 129.5, 129.4, 129.1, 128.9, 127.3, 92.7, 68.4, 45.5, 33.9. IR $\left(\mathrm{v}\right.$ max $\left._{1} \mathrm{Cm}^{-1}\right) 3027(\mathrm{w}), 3065(\mathrm{w}), 3090(\mathrm{w}), 2964$ $(\mathrm{w}), 1707(\mathrm{~s}), 1631(\mathrm{~s}), 1389(\mathrm{~s}), 1421(\mathrm{~m}), 1453(\mathrm{~m}), 1345(\mathrm{~m}), 1180(\mathrm{~s}), 1275(\mathrm{~m}), 1104(\mathrm{~m}), 837(\mathrm{~m})$, 748 (s), 698 (s). HRMS (ESI/QTOF) m/z: $[\mathrm{M}+\mathrm{Na}]^{+}$Calcd for $\mathrm{C}_{18} \mathrm{H}_{19} \mathrm{NNaO}_{2}{ }^{+} 304.1308$; Found 304.1313.

Tert-butyl benzyl(vinyl)carbamate (1d)

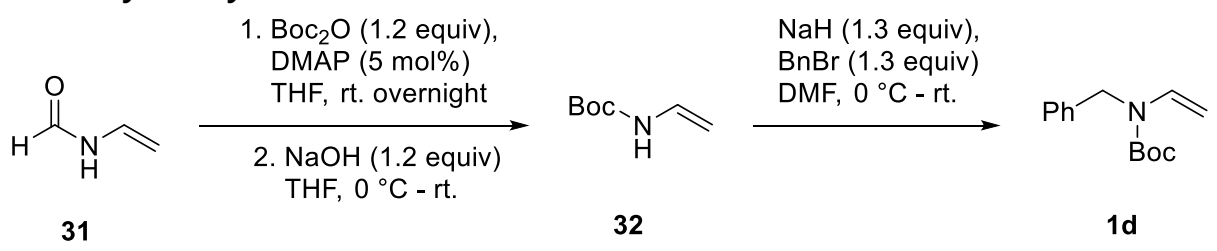

Following a reported procedure, ${ }^{17}$ in a $250 \mathrm{~mL}$, three-necked, round-bottomed flask, $N$ vinylformamide (31, $2.7 \mathrm{~mL}, 38 \mathrm{mmol}, 1.0$ equiv) was dissolved in THF (dry; ca. $130 \mathrm{~mL}$ ). To the resulting pale yellow solution, di-tert-butyl dicarbonate $(10.1 \mathrm{~g}, 46.2 \mathrm{mmol}, 1.2$ equiv) and

\footnotetext{
${ }^{16}$ Milani, B.; Alessio, E.; Mestroni, G.; Sommazzi, A.; Garbassi, F.; Zangrando, E.;Bresciani-Pahor, N.; Randaccio, L. J. Chem. Soc., Dalton Trans., 1994, 1903-1911

${ }_{17}$ Kassir, A. F.; Ragab, S. S.; Nguyen, T. A. M.; Charnay-Pouget, F.; Guillot, R.; Scherrmann, M. C.; Boddaert, T.; Aitken, D. J. J. Org. Chem. 2016, 81, 9983.
} 
DMAP $(0.235 \mathrm{~g}, 1.93 \mathrm{mmol}, 5 \mathrm{~mol} \%)$ were added under nitrogen. The mixture, which rapidly became bright yellow, was then stirred at room temperature overnight. After 16 hours, it was concentrated under reduced pressured. The orange crude oil was then submitted to column chromatography (Biotage, $80 \mathrm{~g} \mathrm{SiO}_{2} ; \mathrm{EtOAc}$ in pentane, 5 to 50\%) to afford tert-butyl formyl(vinyl)carbamate $(4.70 \mathrm{~g}, 27.5 \mathrm{mmol}, 71 \%$ yield) as a yellow oil. The compound was used directly in next step, in a $100 \mathrm{~mL}$ one-necked, round-bottomed flask, tert-butyl formyl(vinyl)carbamate $(4.60 \mathrm{~g}, 26.9 \mathrm{mmol}, 1.0$ equiv) was dissolved in THF (16 mL). The solution was cooled to $0{ }^{\circ} \mathrm{C}$ (ice water bath). Aq. $\mathrm{NaOH}(2.0 \mathrm{M} ; 16 \mathrm{~mL}, 32 \mathrm{mmol}, 1.2$ equiv) was added drop-wise, over a period of 20 minutes (syringe pump). Once the addition was complete, stirring was continued at $0{ }^{\circ} \mathrm{C}$ for another 15 minutes. The suspension was then allowed to warm to room temperature and stirred for additional 3 hours. Water $(30 \mathrm{~mL})$ was then added and the aqueous layer was extracted with MeOtBu $(4 \times 30 \mathrm{~mL})$. The combined organic extracts were washed with water, brine, dried over $\mathrm{Na}_{2} \mathrm{SO}_{4}$, filtered, and concentrated under reduced pressure. The resulting crude solid was dissolved in pentane at room temperature (in order to reduce the volume of pentane, the dissolution was done under ultrasound irradiation). The solution was then allow to stand at $-20{ }^{\circ} \mathrm{C}$ (freezer) overnight. The precipitate was then collected by filtration and washed with a minimal amount of ice-cold pentane. tert-Butyl vinylcarbamate $(32,2.45 \mathrm{~g}, 17.1 \mathrm{mmol}, 64 \%$ yield) was obtained as a crystalline, colorless solid.

${ }^{1} \mathbf{H}$ NMR $\left(400 \mathrm{MHz}\right.$, Acetonitrile- $\left.d_{3}\right) \delta 7.31\left(\mathrm{~s}, 1 \mathrm{H},-\mathrm{CH}=\mathrm{CH}_{2}\right), 6.60(\mathrm{ddd}, J=15.8$,

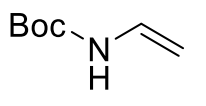
$\left.10.8,8.9 \mathrm{~Hz}, 1 \mathrm{H},-\mathrm{CH}=\mathrm{CH}_{2}\right), 4.47\left(\mathrm{~d}, J=15.8 \mathrm{~Hz}, 1 \mathrm{H},-\mathrm{CH}=\mathrm{CH}_{2}\right), 4.14(\mathrm{~d}, J=8.9 \mathrm{~Hz}$, $1 \mathrm{H}, \mathrm{NH}), 1.43\left(\mathrm{~s}, 9 \mathrm{H}, \mathrm{C}\left(\mathrm{CH}_{3}\right)_{3}\right) .{ }^{3} \mathrm{C}$ NMR $\left(101 \mathrm{MHz}\right.$, Acetonitrile- $\left.d_{3}\right) \delta$ 153.9, 131.4, 92.3, 80.5, 28.4.

Compound was used directly in next step with no further analysis.

Following a reported procedure, ${ }^{18}$ in a $100 \mathrm{~mL}$, two-necked, round-bottomed flask, tert-butyl vinylcarbamate (32, $0.773 \mathrm{~g}, 5.40 \mathrm{mmol}, 1.0$ equiv) was dissolved in DMF (dry; $12.6 \mathrm{~mL})$. The colorless solution was cooled to $0{ }^{\circ} \mathrm{C}$ (ice-water bath) and sodium hydride (60\% dispersion in paraffin; $0.281 \mathrm{~g}, 7.02 \mathrm{mmol}, 1.3$ equiv) was added in single portion. Bubbling was immediately observed. The suspension was stirred at $0{ }^{\circ} \mathrm{C}$ for 30 minutes and at room temperature for another 30 minutes. The mixture looked, at this point, like a yellow-grey turbid solution. Benzyl bromide $(0.84 \mathrm{~mL}, 7.0 \mathrm{mmol}, 1.3$ equiv) was then added drop-wise, followed by a catalytic amount of TBAI (tip of a spatula). The mixture was stirred at room temperature for 3 hours. After this time, full conversion of the starting material was observed based on TLC analysis (pentane:EtOAc 97:3). The reaction was quenched by cautious addition of water $(12 \mathrm{~mL})$, followed by sat. aq. $\mathrm{NH}_{4} \mathrm{Cl}(12 \mathrm{~mL})$. The aqueous layer was then extracted with ether $(4 \times 20$ $\mathrm{mL})$. The combined organic extracts were washed with water $(30 \mathrm{~mL})$, brine $(2 \times 30 \mathrm{~mL})$, dried over $\mathrm{MgSO}_{4}$, filtered, and concentrated under vacuum. The resulting yellow crude oil was submitted to column chromatography (Biotage, $40 \mathrm{~g} \mathrm{SiO}_{2}$; EtOAc in pentane, 0 to 7\%) to provide tert-butyl benzyl(vinyl)carbamate 1d (95\% pure; $0.822 \mathrm{~g}, 3.35 \mathrm{mmol}, 62 \%$ yield) as a yellow oil.

${ }^{18}$ Liu, S.-Y.; Xu, S. WO2015/126400, 2015, A1. 


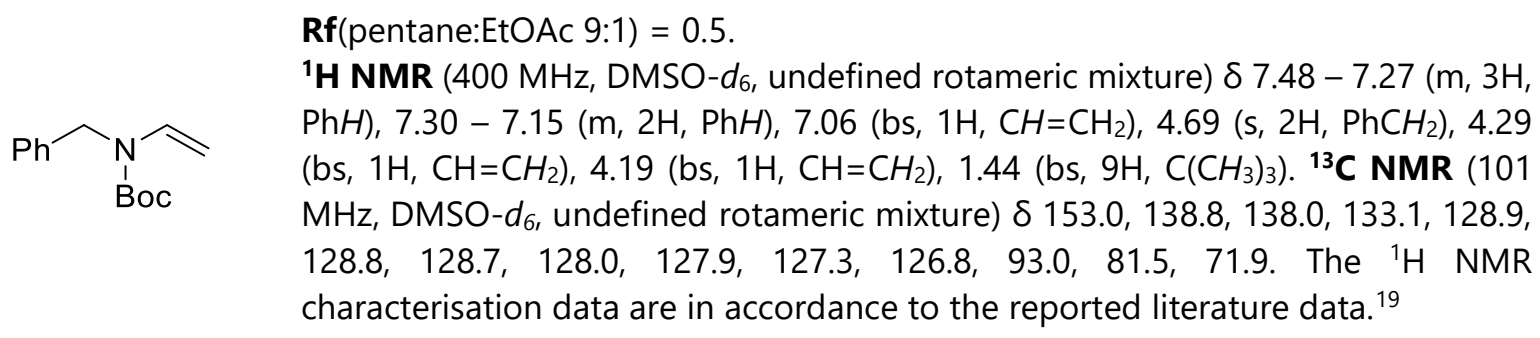

Tert-butyl methyl(vinyl)carbamate (1e)

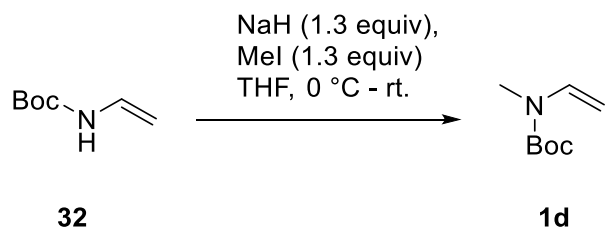

Following a reported procedure, ${ }^{20} \mathrm{~A} 100 \mathrm{~mL}$, two-necked, round-bottomed flask was charged with $\mathrm{NaH}$ (60\% w/w dispersion in mineral oil; $0.192 \mathrm{~g}, 4.80 \mathrm{mmol}, 1.2$ equiv). The flask was evacuated, and backfilled with nitrogen ( 3 times). THF (dry; $30 \mathrm{~mL}$ ) was then added. The resulting suspension was cooled to $0{ }^{\circ} \mathrm{C}$ (ice - water bath) and a solution of $t$-butyl $\mathrm{N}$-vinyl carbamate (32, $0.572 \mathrm{~g}, 4.00 \mathrm{mmol}, 1.0$ equiv) in THF (dry; $10 \mathrm{~mL}$ ) was added slowly, by syringe at the same temperature. Immediately, moderate gas bubbling was observed. The resulting pale yellow mixture was stirred at $0{ }^{\circ} \mathrm{C}$ for 30 minutes. Methyl iodide $(0.39 \mathrm{~mL}, 6.4 \mathrm{mmol}, 1.6$ equiv) was then added. The cooling bath was removed and stirring was continued under $\mathrm{Ar}$ (balloon) overnight. The reaction was then quenched by addition of sat. aq. $\mathrm{NH}_{4} \mathrm{Cl}(30 \mathrm{~mL})$. The aqueous layer was separated and extracted with EtOAc $(3 \times 30 \mathrm{~mL})$. The combined organic layers were washed with brine, dried over $\mathrm{MgSO}_{4}$, filtered, and concentrated under reduced pressure. The resulting crude oil was submitted to column chromatography $\left(\mathrm{SiO}_{2}\right.$; EtOAc:pentane 0:100 to $25 / 75)$ to give tert-butyl $\mathrm{N}$-methyl $\mathrm{N}$-vinyl carbamate $(\mathbf{1 d}, 0.282 \mathrm{~g}$, $1.70 \mathrm{mmol}, 45 \%$ yield) as a colorless oil.

Although this compound is known, ${ }^{21}$ no NMR data has been reported at RT.<smiles>C=CN(C)C(=O)OC(C)(C)C</smiles>
$\mathbf{R f}($ pentane:EtOAc $=9: 1)=0.55$.

${ }^{1} \mathbf{H}$ NMR $\left(400 \mathrm{MHz}\right.$, Acetonitrile-d3) $\delta 7.15\left(\mathrm{~m}, 1 \mathrm{H},-\mathrm{CH}=\mathrm{CH}_{2}\right), 4.27(\mathrm{~d}, J=15.8 \mathrm{~Hz}$, $\left.1 \mathrm{H},-\mathrm{CH}=\mathrm{CH}_{2}\right), 4.18\left(\mathrm{~m}, 1 \mathrm{H},-\mathrm{CH}=\mathrm{CH}_{2}\right), 2.96\left(\mathrm{~s}, 3 \mathrm{H}, \mathrm{CH}_{3}\right), 1.47\left(\mathrm{~s}, 9 \mathrm{H}, \mathrm{C}\left(\mathrm{CH}_{3}\right)_{3}\right) .{ }^{13} \mathrm{C}$

NMR $\left(101 \mathrm{MHz}\right.$, Acetonitrile- $\left.d_{3}\right) \delta 153.3,134.7,90.7,81.2,29.6,28.0$.

IR $\left(v_{\max } \mathrm{cm}^{-1}\right) 3116(\mathrm{w}), 2978(\mathrm{w}), 1708(\mathrm{~s}), 1626(\mathrm{~s}), 1479(\mathrm{~m}), 1459(\mathrm{w}), 1436(\mathrm{~m}), 1410(\mathrm{~m}), 1352(\mathrm{~s})$, $1318(\mathrm{~s}), 1290(\mathrm{~m}), 1254(\mathrm{w}), 1145(\mathrm{~s}), 1060(\mathrm{~m}), 979(\mathrm{w}), 865(\mathrm{~m}), 835(\mathrm{~m}), 768(\mathrm{~m}), 659(\mathrm{w})$. HRMS (APPI/LTQ-Orbitrap) m/z: [M + Na] ${ }^{+}$Calcd for $\mathrm{C}_{8} \mathrm{H}_{15} \mathrm{NNaO}_{2}{ }^{+}$180.0995; Found 180.0998.

Tert-butyl allyl(vinyl)carbamate (1f)

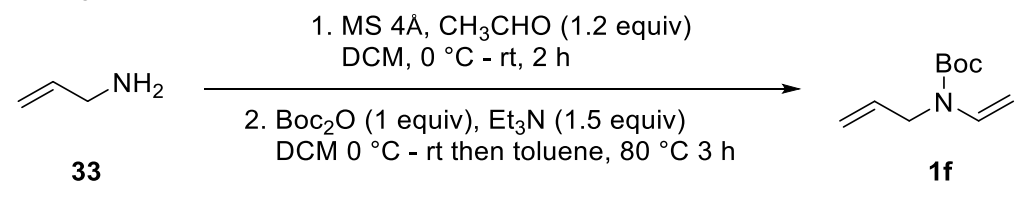

\footnotetext{
19 Bach, T. and Schröder, J. Liebigs Ann./Recl., 1997, 1997, 2226

20 Boyington, A. J.; Seath, C. P.; Zearfoss, A. M.; Xu, Z.; Jui, N. T. J. Am. Chem. Soc. 2019, 141, 4147.

${ }^{21}$ Chu, S.; Münster, N.; Balan, T.; Smith, M. D. Angew. Chem. Int. Ed. 2016, 55,14306.
} 
Following a modified reported procedure, ${ }^{22}$ to a mixture of allylamine $(33,1.5 \mathrm{~mL}, 20.1 \mathrm{mmol}$, 1.0 equiv) and $4 \AA$ mol sieves $(2 \mathrm{~g})$ in $\mathrm{CH}_{2} \mathrm{Cl}_{2}(25 \mathrm{~mL})$ at $0{ }^{\circ} \mathrm{C}$ was added acetaldehyde $(1.4 \mathrm{~mL}$, $24 \mathrm{mmol}, 1.2$ equiv) dropwise. The solution was warmed to rt over $1 \mathrm{~h}$, stirred for an additional $1 \mathrm{~h}$, and decanted. To the resultant solution at $0{ }^{\circ} \mathrm{C}$, triethylamine $(3.90 \mathrm{~mL}, 30.1 \mathrm{mmol}, 1.5$ equiv) and di-tert-butyl dicarbonate $(4.37 \mathrm{~g}, 20.1 \mathrm{mmol}, 1.0$ equiv) were added. The mixture was warmed to rt and stirred for $15 \mathrm{~h}$. The solution was concentrated, and toluene ( $30 \mathrm{~mL})$ was added. The solution was heated at $70{ }^{\circ} \mathrm{C}$ for $3 \mathrm{~h}$ and then concentrated. Purification by silicagel chromatography $\left(\mathrm{SiO}_{2}-\mathrm{Et}_{3} \mathrm{~N}\right.$ deactivated; Pent:Et ${ }_{2} \mathrm{O}$ 98:2) afforded tert-butyl allyl(vinyl)carbamate 1 e $(0.5496 \mathrm{~g}, 3.00 \mathrm{mmol}, 15 \%$ yield $)$ as a colorless oil.

Rf (pentane: $\left.\mathrm{Et}_{2} \mathrm{O} 95: 5\right)=0.4$.

$\begin{array}{ll}\text { Boc } & { }^{1} \mathbf{H} \text { NMR }\left(400 \mathrm{MHz}, \text { Acetonitrile- } d_{3}\right) \delta 7.06\left(\mathrm{dd}, J=15.8,9.4 \mathrm{~Hz}, 1 \mathrm{H}, \mathrm{NCH}=\mathrm{CH}_{2}\right), \\ & 5.78\left(\mathrm{ddt}, J=17.2,10.3,5.0 \mathrm{~Hz}, 1 \mathrm{H}, \mathrm{CH}=\mathrm{CH}_{2}\right), 5.17-4.94\left(\mathrm{~m}, 2 \mathrm{H}, \mathrm{CH}=\mathrm{CH}_{2}\right), 4.30 \\ & \left(\mathrm{~d}, J=16.0 \mathrm{~Hz}, 1 \mathrm{H}, \mathrm{NCH}=\mathrm{CH}_{2}\right), 4.18\left(\mathrm{~d}, 9.6 \mathrm{~Hz}, 1 \mathrm{H}, \mathrm{CH}=\mathrm{CH}_{2}\right), 4.13(\mathrm{~d}, J=5.0 \mathrm{~Hz}, \\ & \left.2 \mathrm{H}, \mathrm{CH}_{2}\right), 1.46\left(\mathrm{~s}, 9 \mathrm{H}, \mathrm{C}\left(\mathrm{CH}_{3}\right)_{3}\right) .\end{array}$

${ }^{13}$ C NMR $\left(101 \mathrm{MHz}\right.$, Acetonitrile- $\left.d_{3}\right) \delta 152.7,133.5,133.3,115.7,91.4,81.4,45.7,27.9$. IR $\left(v_{\max } \mathrm{cm}^{-1}\right)$ 3006 (s), 2985 (s), 2942 (s), 2924 (s), 2909 (s), 2883 (s), 1723 (s), 1703 (s), 1633 (s), 1626 (s), 1618 (s), 1419 (s), 1364 (s), 1239 (s), 1146 (s). HRMS (APPI/LTQ-Orbitrap) m/z: [M + H] ${ }^{+}$Calcd for $\mathrm{C}_{10} \mathrm{H}_{18} \mathrm{NO}_{2}{ }^{+}$ 184.1332; Found 184.1327.

Tert-butyl (2-tert-butyldimethylsilyl)oxy)ethyl)(vinyl)carbamate (1g)

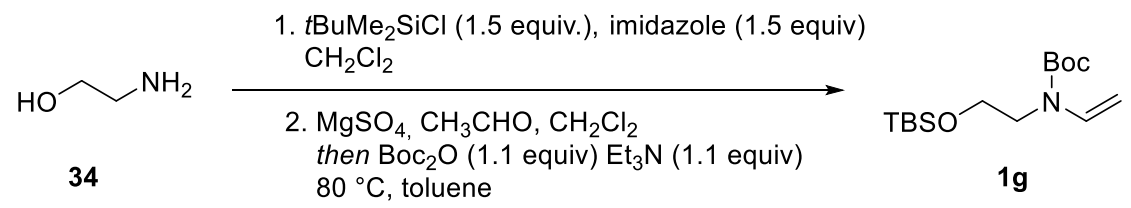

Under standard silylating conditions: in a $50 \mathrm{~mL}$ single-necked, round bottomed flask, a solution of tert-butyldimethylchlorosilane $(2.41,16.0 \mathrm{mmol}, 1.5$ equiv) in dichloromethane $(7.0$ $\mathrm{mL}$ ) was added drop-wise over a period of $3 \mathrm{~min}$ to a stirred solution of ethanolamine (34, $0.80 \mathrm{~mL}, 13 \mathrm{mmol}, 1.0$ equiv) and imidazole (1.36 g, $20.0 \mathrm{mmol}, 1.5$ equiv) in dichloromethane $(14 \mathrm{~mL})$ at room temperature. The resulting mixture initially looked like a milky solution that became clear and colorless after being stirred at room temperature for 1 hour. Water $(20 \mathrm{~mL})$ was then added, and the layers were separated. The aqueous layer was extracted with dichloromethane $(2 \times 20 \mathrm{~mL})$, and the combined organic extracts were dried over $\mathrm{MgSO}_{4}$, filtered and concentrated in vacuo to give 2-((tert-butyldimethylsilyl)oxy)ethanamine (35, 2.05 g, $11.7 \mathrm{mmol}, 88 \%$ yield) as pale yellow oil, which was used directly in next step with no further analysis.

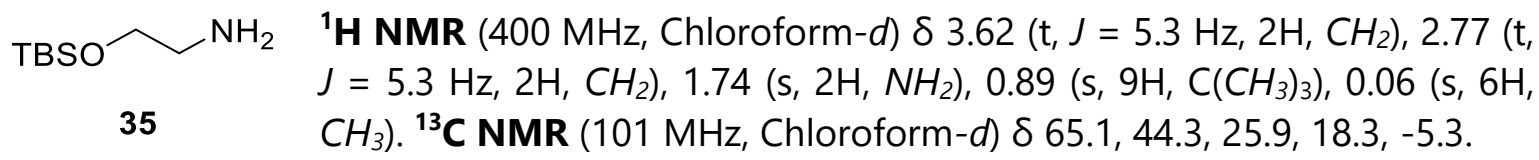

A flame- $d$ ried, $100 \mathrm{~mL}$ round-bottomed, two-necked flask was charged with anhydrous $\mathrm{MgSO}_{4}$ (stored in the glove box; $4.5 \mathrm{~g}$ ), closed, evacuated, and backfilled with nitrogen. $\mathrm{CH}_{2} \mathrm{Cl}_{2}$ (dry; 10 $\mathrm{mL}$ ) was added, followed by 2-((tert-butyldimethylsilyl)oxy)ethanamine $(\mathbf{3 5}, 1.75 \mathrm{~g}, 10.0 \mathrm{mmol}$,

${ }^{22}$ Cossey, K. N.; Funk, R. L. J. Am. Chem. Soc. 2004, 126, 12216-12217. 
1.0 equiv). The resulting suspension was cooled down to $0{ }^{\circ} \mathrm{C}$ (ice/water bath). Acetaldehyde $\left(0.80 \mathrm{~mL}, 14 \mathrm{mmol}, 1.4\right.$ equiv) was then added. The mixture was stirred at $0{ }^{\circ}$ for 45 minutes, and then at room temperature for additional 45 minutes. The solids were then removed through rapid filtration. $\mathrm{CH}_{2} \mathrm{Cl}_{2}$ was then distilled off (rotary evaporator) to give a red crude imine. To the crude imine was added a solution of di-tert-butyl dicarbonate $(2.40 \mathrm{~g}, 11.0 \mathrm{mmol}$, 1.1 equiv) in toluene (dry; $5.0 \mathrm{~mL}$ ), followed by triethylamine $(1.5 \mathrm{~mL}, 11 \mathrm{mmol}, 1.1$ equiv). The resulting orange suspension was stirred at $80^{\circ} \mathrm{C}$ for 5 hours, slowly becoming a dark orange solution. The reaction was stopped and the volatiles were removed under reduced pressure. The resulting crude yellow-orange oil was submitted to column chromatography $\left(\mathrm{SiO}_{2}\right.$; Pentane: $\mathrm{Et}_{2} \mathrm{O} 248: 2$ to $24: 1$ ). The desired product was obtained as a mixture with unreacted $\mathrm{Boc}_{2} \mathrm{O}$. The excess $\mathrm{Boc}_{2} \mathrm{O}$ was removed as following: the eluate was dissolved in $\mathrm{EtOH}(5 \mathrm{~mL})$ and imidazole ( $300 \mathrm{mg}$ ) and DMAP ( $54.0 \mathrm{mg}, 0.1 \mathrm{eq}$ compared to imidazole) were added. The resulting mixture was stirred at room temperature for 10 minutes. It was then concentrated under reduced pressure. The crude oil was submitted to column chromatography (Biotage, 24 g $\mathrm{SiO}_{2} ;$ EtOAc in pentane, 1 to $\left.5 \%\right)$ to furnish pure tert-butyl (2-((tertbutyldimethylsilyl)oxy)ethyl)(vinyl)carbamate $1 \mathbf{g}(0.379 \mathrm{~g}, 1.26 \mathrm{mmol}, 13 \%$ yield) as a colorless oil.

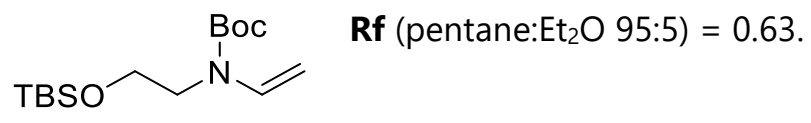

${ }^{1} \mathbf{H}$ NMR $\left(400 \mathrm{MHz}\right.$, Acetonitrile- $\left.d_{3}\right) \delta 7.03\left(\mathrm{~m}, 1 \mathrm{H},-\mathrm{CH}=\mathrm{CH}_{2}\right), 4.40\left(\mathrm{~d}, J=16.0 \mathrm{~Hz}, 1 \mathrm{H},-\mathrm{CH}=\mathrm{CH}_{2}\right), 4.20$ (br s, $\left.1 \mathrm{H},-\mathrm{CH}=\mathrm{CH}_{2}\right), 3.72\left(\mathrm{td}, J=6.1,0.8 \mathrm{~Hz}, 2 \mathrm{H}, \mathrm{CH}_{2}\right), 3.60\left(\mathrm{t}, J=6.2 \mathrm{~Hz}, 2 \mathrm{H}, \mathrm{CH}_{2}\right), 1.46\left(\mathrm{~s}, 9 \mathrm{H}, \mathrm{C}\left(\mathrm{CH}_{3}\right)_{3}\right)$, $0.88\left(\mathrm{~s}, 9 \mathrm{H}, \mathrm{C}\left(\mathrm{CH}_{3}\right)_{3}\right), 0.04\left(\mathrm{~s}, 6 \mathrm{H}, \mathrm{CH}_{3}\right.$ in TBS). ${ }^{13} \mathrm{C} \mathrm{NMR}\left(101 \mathrm{MHz}\right.$, Acetonitrile- $\left.d_{3}\right) \delta 153.8,134.2,91.7$, 81.7, 60.4, 45.9, 28.4, 26.2, 18.9, -5.2. IR $\left(\nu_{\max ,} \mathrm{Cm}^{-1}\right) 2957(\mathrm{~m}), 2862(\mathrm{w}), 1707(\mathrm{~s}), 1631(\mathrm{~m}), 1466(\mathrm{~m})$, 1358 (s), $1250(\mathrm{~m}), 1142$ (s), 1117 (s), 831 (s), 780 (s), 926 (w), 977 (w). HRMS (ESI/QTOF) m/z: [M + $\mathrm{Na}]^{+}$Calcd for $\mathrm{C}_{15} \mathrm{H}_{31} \mathrm{NNaO}_{3} \mathrm{Si}^{+}$324.1965; Found 324.1966.

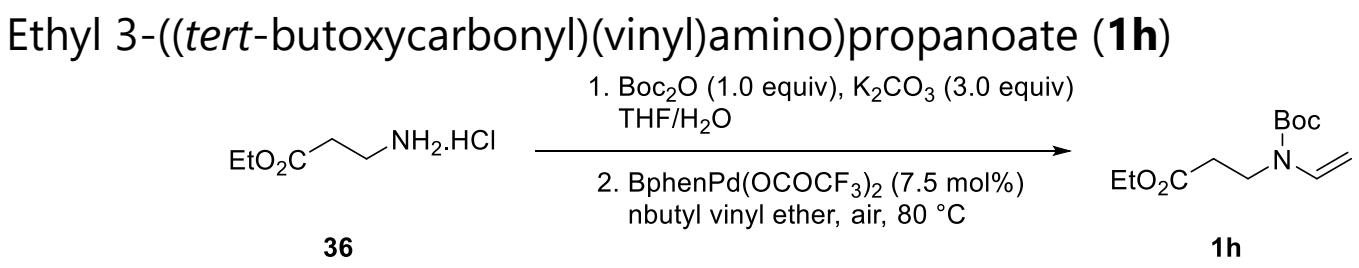

In a $50 \mathrm{~mL}$ single-necked, round-bottomed flask, ethyl 3-aminobutanoate hydrochloride (36, $0.550 \mathrm{~g}, 3.58 \mathrm{mmol}, 1.0$ equiv), $\mathrm{Boc}_{2} \mathrm{O}\left(0.781 \mathrm{~g}, 3.58 \mathrm{mmol}, 1.0\right.$ equiv) and $\mathrm{K}_{2} \mathrm{CO}_{3}(1.485 \mathrm{~g}, 10.74$ mmol) were suspended in a mixture of THF: $\mathrm{H}_{2} \mathrm{O}(10 \mathrm{~mL}, 1: 1)$. The mixture was stirred at room temperature for 4 hours. It was then diluted with water $(20 \mathrm{~mL})$ and extracted with EtOAc (20 $\mathrm{mL} \times 2$ ). The combined organic extracts were washed with brine, dried over $\mathrm{MgSO}_{4}$, filtered, and concentrated in vacuo to give pure ethyl 3-((tert-butoxycarbonyl)amino)propanoate (37, $0.707 \mathrm{~g}, 3.25 \mathrm{mmol}, 91 \%$ yield) as a colorless oil.

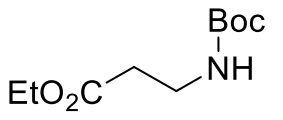

37
${ }^{1} \mathbf{H}$ NMR (400 MHz, Acetonitrile- $\left.d_{3}\right) \delta 5.37(\mathrm{~s}, 1 \mathrm{H}, \mathrm{NH}), 4.09(\mathrm{q}, J=7.1 \mathrm{~Hz}, 2 \mathrm{H}$, $\left.\mathrm{OCH}_{2} \mathrm{CH}_{3}\right), 3.26\left(\mathrm{q}, J=6.5 \mathrm{~Hz}, 2 \mathrm{H}, \mathrm{CH}_{2}\right), 2.43\left(\mathrm{t}, J=6.6 \mathrm{~Hz}, 2 \mathrm{H}, \mathrm{CH}_{2}\right), 1.39(\mathrm{~s}$, $9 \mathrm{H}, \mathrm{C}\left(\mathrm{CH}_{3}\right)_{3}$ in $\left.\mathrm{Boc}\right), 1.21\left(\mathrm{t}, J=7.1 \mathrm{~Hz}, 3 \mathrm{H}, \mathrm{OCH}_{2} \mathrm{CH}_{3}\right) \cdot{ }^{13} \mathbf{C}$ NMR $(101 \mathrm{MHz}$, Acetonitrile- $\left.d_{3}\right) \delta 172.7,156.7,79.3,61.1,37.1,35.4,28.5,14.5$.

The compound was used directly in next step with no further analysis. 


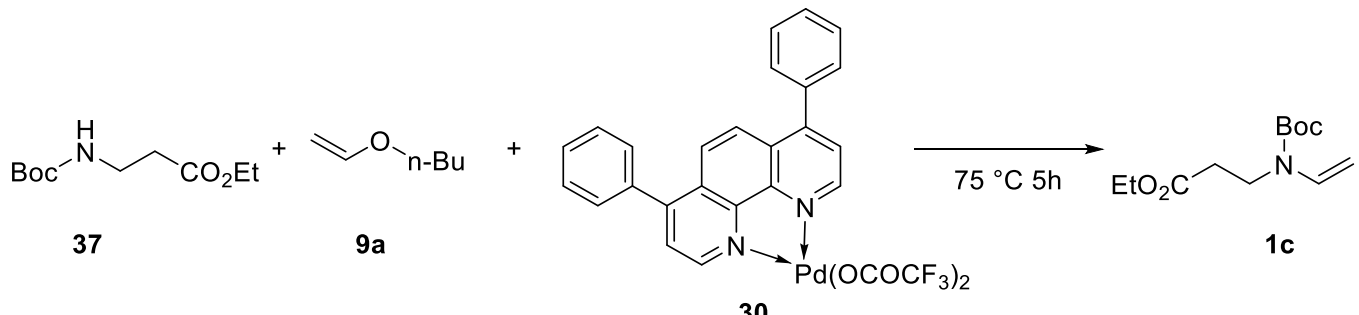

30

Following an adapted reported procedure, ${ }^{23}$ a $5 \mathrm{~mL}$ round-bottomed test tube was charged with (dpp) $\mathrm{Pd}\left(\mathrm{O}_{2} \mathrm{CCF}_{3}\right)_{2}(31.0 \mathrm{mg}, 0.0460 \mathrm{mmol}, 5 \mathrm{~mol} \%)$. Butyl vinyl ether $(1.5 \mathrm{~mL}, 11 \mathrm{mmol}, 12$ equiv) was added, followed by ethyl 3-((tert-butoxycarbonyl)amino)propanoate (0.200 g, 0.921 mmol, 1.0 equiv). The vial was sealed with a PTFE septum, which was then pierced with a needle (gauge 18 - "pink needle") in order to ensure exposure to air. The resulting brown-orange suspension was stirred at $80{ }^{\circ} \mathrm{C}$ for 2 hours. After this time, the mixture looked like a clear orange solution. According to TLC analysis, the starting material was still present after this time, with no further progress upon stirring the mixture at the same temperature for additional 60 minutes. A further amount of catalyst ( $16.0 \mathrm{mg}, 0.0260 \mathrm{mmol}, 2.5 \mathrm{~mol} \%$; overall $7.5 \mathrm{~mol} \%)$ was therefore added and stirring was continued at $80^{\circ} \mathrm{C}$ for 2 hours. The reaction mixture was then allowed to cool down to room temperature and was subsequently submitted to column chromatography (Biotage, $25 \mathrm{~g} \mathrm{SiO}_{2}$; EtOAc in pentane, 2 to 20\%). ${ }^{15}$ Pure ethyl 3-((tertbutoxycarbonyl)(vinyl)amino)propanoate $1 \mathrm{~h}(0.121 \mathrm{~g}, 0.499 \mathrm{mmol}, 54 \%$ yield) was obtained as a colorless oil.

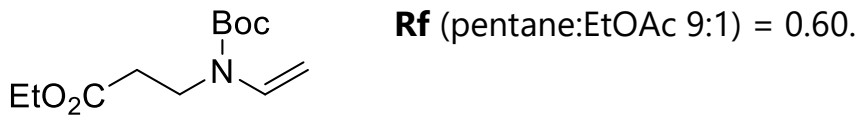

${ }^{1} \mathrm{H}$ NMR $\left(400 \mathrm{MHz}\right.$, Acetonitrile- $\left.d_{3}\right) \delta 7.00\left(\mathrm{dd}, J=16.1,9.6 \mathrm{~Hz}, 1 \mathrm{H},-\mathrm{CH}^{2} \mathrm{CH}_{2}\right), 4.36(\mathrm{~d}, J=16.1 \mathrm{~Hz}$, $\left.1 \mathrm{H},-\mathrm{CH}=\mathrm{CH}_{2}\right), 4.21\left(\mathrm{~d}, J=9.5 \mathrm{~Hz}, 1 \mathrm{H},-\mathrm{CH}=\mathrm{CH}_{2}\right), 4.08\left(\mathrm{q}, J=7.1 \mathrm{~Hz}, 2 \mathrm{H}, \mathrm{OCH}_{2} \mathrm{CH}_{3}\right), 3.81-3.68(\mathrm{~m}, 2 \mathrm{H}$, $\left.\mathrm{CH}_{2}\right), 2.49\left(\mathrm{dd}, J=8.4,6.5 \mathrm{~Hz}, 2 \mathrm{H}, \mathrm{CH}_{2}\right), 1.46\left(\mathrm{~s}, 9 \mathrm{H}, \mathrm{C}\left(\mathrm{CH}_{3}\right)_{3}\right.$ in $\left.\mathrm{Boc}\right), 1.21\left(\mathrm{t}, J=7.1 \mathrm{~Hz}, 3 \mathrm{H}, \mathrm{OCH}_{2} \mathrm{CH}_{3}\right)$.

${ }^{13} \mathrm{C}$ NMR $\left(101 \mathrm{MHz}\right.$, Acetonitrile- $\left.d_{3}\right) \delta 171.8,153.0,132.9,91.0,81.7,60.8,39.3,32.3,27.9,14.1$. IR $\left(v_{\max } \mathrm{cm}^{-1}\right) 3382(\mathrm{w}), 2976(\mathrm{w}), 1732(\mathrm{~m}), 1688(\mathrm{~m}), 1516(\mathrm{~m}), 1370(\mathrm{~m}), 1415(\mathrm{w}), 1447(\mathrm{w}), 1282(\mathrm{~m})$, $1250(\mathrm{~s}), 1167(\mathrm{~s}), 1072(\mathrm{~m}), 1021(\mathrm{~m}), 977(\mathrm{~m}), 856(\mathrm{~m}), 787(\mathrm{~m}), 647(\mathrm{~m})$. HRMS (ESI/QTOF) m/z: [M $+\mathrm{Na}]^{+}$Calcd for $\mathrm{C}_{12} \mathrm{H}_{21} \mathrm{NNaO}_{4}{ }^{+}$266.1363; Found 266.1362.

Tert-butyl cyclohexenyl(vinyl)carbamate (1i)

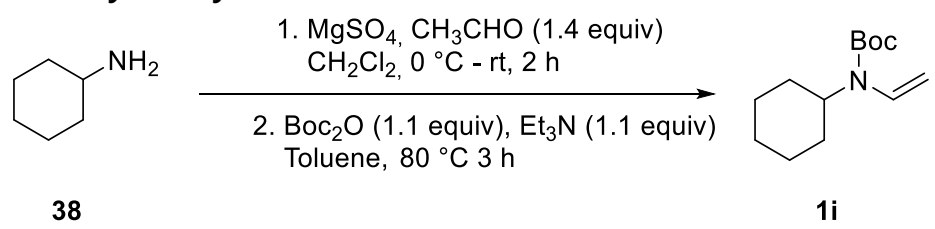

A flame-dried, $100 \mathrm{~mL}$ round-bottomed, two-necked flask was charged with anhydrous $\mathrm{MgSO}_{4}$ (stored in the glove box; $4.5 \mathrm{~g}$ ), closed, evacuated, and backfilled with nitrogen. $\mathrm{CH}_{2} \mathrm{Cl}_{2}$ (dry; 10 $\mathrm{mL}$ ) was added followed by cyclohexanamine (38, $1.2 \mathrm{~mL}, 10 \mathrm{mmol}, 1.0$ eq.). The resulting suspension was cooled down to $0{ }^{\circ} \mathrm{C}$ (ice/water bath). Acetaldehyde $(0.80 \mathrm{~mL}, 14 \mathrm{mmol}, 1.4$ eq.) was then added. The mixture was stirred and allowed to warm to room temperature over

${ }^{23}$ Brice, J. L.; Meerdink, J. E.; Stahl, S. S. Org. Lett. 2004, 6, 1845-1848. 
a period of 1 hours, and then stirred at room temperature for 1 additional hour. The solids were then removed through rapid filtration. $\mathrm{CH}_{2} \mathrm{Cl}_{2}$ was then distilled off (rotary evaporator). The crude imine was used directly in the next step with no further purification. To the crude imine was added a solution of di-tert-butyl dicarbonate $(2.40 \mathrm{~g}, 11.0 \mathrm{mmol}, 1.1 \mathrm{eq}$.) in toluene (dry; $5.0 \mathrm{~mL}$ ), followed by triethylamine $(1.5 \mathrm{~mL}, 11 \mathrm{mmol}, 1.1 \mathrm{eq}$.). The resulting yellow solution was stirred at $80^{\circ} \mathrm{C}$ for 3 hours. The reaction was stopped and the volatiles were removed under reduced pressure. The resulting crude yellow-orange oil was submitted to column chromatography $\left(\mathrm{SiO}_{2} ;\right.$ Pentane/Et ${ }_{2} \mathrm{O} 248 / 2$ to $\left.24 / 1\right)$. The desired product was obtained as a mixture with unreacted $\mathrm{Boc}_{2} \mathrm{O}$. The exceeding $\mathrm{Boc}_{2} \mathrm{O}$ was removed as following: the eluate was dissolved in EtOH ( $5 \mathrm{~mL}$ ) and imidazole $(300 \mathrm{mg}$ ) and DMAP (54.0 mg, 0.1 eq compared to imidazole) were added. The resulting mixture was stirred at room temperature for 10 minutes. It was then concentrated under reduced pressure. The crude oil was submitted to column chromatography (Biotage, $24 \mathrm{~g} \mathrm{SiO}_{2} ; \mathrm{Et}_{2} \mathrm{O}$ in pentane, 1 to $5 \%$ ) to furnish pure tert-butyl cyclohexyl(vinyl)carbamate $1 \mathbf{i}$ as a pale yellow oil $(0.607 \mathrm{~g}, 2.45 \mathrm{mmol}, 25 \%$ yield).

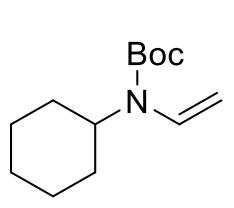

Rf (pentane/Et $\left.{ }_{2} \mathrm{O} 95 / 5\right) 0.5$.

${ }^{1} \mathbf{H}$ NMR $\left(400 \mathrm{MHz}\right.$, Acetonitrile- $\left.d_{3}\right) \delta 6.82\left(\mathrm{dd}, J=16.1,9.6 \mathrm{~Hz}, 1 \mathrm{H},-\mathrm{CH}=\mathrm{CH}_{2}\right)$, $4.59\left(\mathrm{~d}, J=16.1 \mathrm{~Hz}, 1 \mathrm{H},-\mathrm{CH}=\mathrm{CH}_{2}\right), 4.26\left(\mathrm{~d}, J=9.6 \mathrm{~Hz}, 1 \mathrm{H},-\mathrm{CH}=\mathrm{CH}_{2}\right), 3.65(\mathrm{~m}$, $1 \mathrm{H}, \mathrm{NCH}), 2.01(\mathrm{dd}, J=12.6,3.7 \mathrm{~Hz}, 2 \mathrm{H}, \mathrm{Cy}), 1.84-1.74(\mathrm{~m}, 2 \mathrm{H}, \mathrm{Cy}), 1.68-1.57$ $(\mathrm{m}, 3 \mathrm{H}, \mathrm{Cy}), 1.46\left(\mathrm{~s}, 9 \mathrm{H}, \mathrm{C}\left(\mathrm{CH}_{3}\right)_{3}\right), 1.33(\mathrm{qt}, J=12.9,3.7 \mathrm{~Hz}, 2 \mathrm{H}, \mathrm{Cy}), 1.13$ (qt, $J=$ $13.0,3.6 \mathrm{~Hz}, 1 \mathrm{H}, \mathrm{Cy})$.

${ }^{13} \mathrm{C} \mathrm{NMR}\left(101 \mathrm{MHz}\right.$, Acetonitrile- $\left.d_{3}\right) \delta 153.6,134.1,93.2,81.1,55.9,30.2,28.1,26.7,25.9$. IR $\left(v_{\max } \mathrm{cm}^{-}\right.$ 1) $2979(\mathrm{~m}), 2930$ (m), 1704 (s), 1622 (s), 1171 (s), 1146 (s). HRMS (APCI/QTOF) m/z: [M + Na]+ Calcd for $\mathrm{C}_{13} \mathrm{H}_{23} \mathrm{NNaO}_{2}{ }^{+} 248.1621$; Found 248.1621 .

Benzyl phenethyl(propen-2-yl)carbamate (1/k)

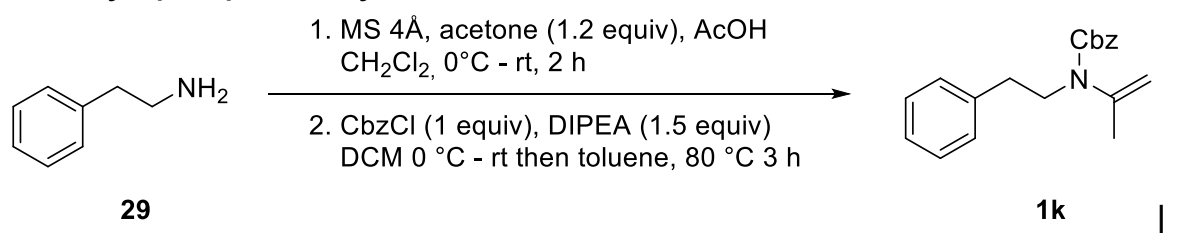

Based on a modified reported procedure, to a solution of 2-phenylethanamine $(29,1.6 \mathrm{ml}, 13$ mmol, 1 equiv), acetic acid ( $0.14 \mathrm{~mL}, 2.5 \mathrm{mmol}, 0.2$ equiv) and $4 \AA$ mol sieves ( $2.8 \mathrm{~g})$ in $\mathrm{CH}_{2} \mathrm{Cl}_{2}$ $(16 \mathrm{~mL})$ at $0{ }^{\circ} \mathrm{C}$ was added propan-2-one $(1.0 \mathrm{~mL}, 14 \mathrm{mmol}, 1.2$ equiv) dropwise. The solution was warmed to RT and stirred for $14 \mathrm{~h}$ and decanted. To the resulting solution at $0{ }^{\circ} \mathrm{C}$ were added $\mathrm{CH}_{2} \mathrm{Cl}_{2}(10 \mathrm{~mL})$, benzyl chloroformate $(1.9 \mathrm{~mL}, 13 \mathrm{mmol}, 1$ equiv) and $N$-ethyl- $N$ isopropylpropan-2-amine $(3.0 \mathrm{~mL}, 18 \mathrm{mmol}, 1.5$ equiv). The reaction mixture was warmed to RT and stirred for $18 \mathrm{~h}$. The solution was concentrated and toluene $(10 \mathrm{~mL})$ was added. The solution was heated to $80{ }^{\circ} \mathrm{C}$ for $36 \mathrm{~h}$ and then concentrated. The crude oil was purified by column chromatography $\left(\mathrm{SiO}_{2}\right.$, pentane:Et ${ }_{2} \mathrm{O}, 100: 0$ to $\left.90: 10\right)$ affording $\mathbf{1 k}$ as a colorless oil ( $0.351 \mathrm{~g}, 1.20 \mathrm{mmol}, 90 \%$ purity, $8 \%$ yield).

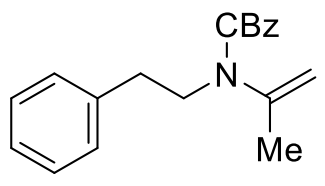

Rf (pentane:EtOAc 9:1) $=0.7$.

${ }^{1} \mathbf{H}$ NMR $\left(400 \mathrm{MHz}\right.$, Acetonitrile- $\left.d_{3}\right) \delta 7.49-7.27(\mathrm{~m}, 7 \mathrm{H}, \mathrm{PhH}), 7.28-7.19(\mathrm{~m}$, $3 \mathrm{H}, \mathrm{PhH}), 5.12\left(\mathrm{~s}, 2 \mathrm{H}, \mathrm{OCH} \mathrm{PH}_{2} \mathrm{Ph}, 4.93\left(\mathrm{q}, J=1.3 \mathrm{~Hz}, 1 \mathrm{H}, \mathrm{C}=\mathrm{CH}_{2}\right), 4.83(\mathrm{~m}, 1 \mathrm{H}\right.$, $\left.\mathrm{C}=\mathrm{CH}_{2}\right), 3.77-3.62\left(\mathrm{~m}, 2 \mathrm{H}, \mathrm{CH}_{2}\right), 3.02-2.86\left(\mathrm{~m}, 2 \mathrm{H}, \mathrm{CH}_{2}\right), 1.88\left(\mathrm{~s}, 3 \mathrm{H}, \mathrm{CH}_{3}\right)$. 
${ }^{13}$ C NMR (101 MHz, Acetonitrile- $d_{3}$, as a not fully resolved mixture of rotamers) $\delta 154.9,145.7,139.8$, 137.7, 129.4, 129.4, 129.2, 129.0, 129.0, 128.8, 128.8, 128.7, 128.5, 128.3, 128.1, 128.1, 127.8, 126.8, 126.8, 110.9, 90.5, 67.2, 67.1, 64.6, 51.1, 46.8, 36.9, 35.2, 27.0, 21.1. IR $\left(v_{\max ,} \mathrm{cm}^{-1}\right) 2987$ (s), $2972(\mathrm{~s})$, 2959 (s), 2900 (s), 1760 (s), 1699 (s), 1685 (s), 1649 (s), 1403 (s), 1304 (s), 1099 (s), 1067 (s). HRMS (APPI/LTQ-Orbitrap) m/z: [M + H] ${ }^{+}$Calcd for $\mathrm{C}_{19} \mathrm{H}_{22} \mathrm{NO}_{2}{ }^{+}$296.1645; Found 296.1636.

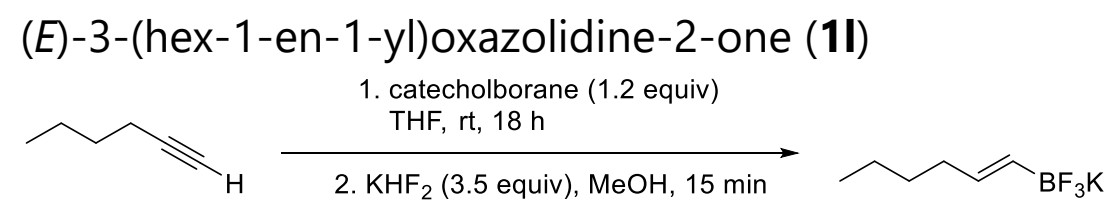

39

40

Following a modified reported procedure, ${ }^{24}$ in sealed $20 \mathrm{~mL}$, round-bottomed vial, 1-hexyne $(39,0.70 \mathrm{~mL}, 5.9 \mathrm{mmol}, 1.0$ equiv) and catecholborane $(0.77 \mathrm{~mL}, 7.1 \mathrm{mmol}, 1.20$ equiv) were dissolved in THF (dry; $19 \mathrm{~mL}$ ) and the mixture was stirred under reflux for 18 hours. After this time, the pale yellow solution was allowed to cool down to room temperature, transfered into a $25 \mathrm{~mL}$, round bottomed flask and concentrated under reduced pressure. Water $(0.8 \mathrm{~mL})$ was added to the residue, with immediate formation of a colorless solid. The suspension was vigorously stirred for 4 hours at room temperature. The solid was collected by filtration and washed with water. (E)-Hex-1-en-1-ylboronic acid $(0.469 \mathrm{~g}, 3.66 \mathrm{mmol}, 62 \%$ yield) was obtained as a colorless solid, which was directly submitted to the following step.

Following a reported procedure, ${ }^{25}$ in a $25 \mathrm{~mL}$, round bottomed flask, $(E)$-hex-1-en-1-ylboronic acid $(0.469 \mathrm{~g}, 3.66 \mathrm{mmol}, 1.0$ equiv) was dissolved in the minimal volume of $\mathrm{MeOH}(1.2 \mathrm{~mL})$. A solution of $\mathrm{KHF}_{2}(1.00 \mathrm{~g}, 12.8 \mathrm{mmol}, 3.5$ equiv) in water $(2.9 \mathrm{~mL} ; 4.5 \mathrm{M})$ was added slowly, causing the rapid precipitation of a colorless solid. The suspension was stirred at room temperature for 15 minutes. The solid (potassium (E)-trifluoro(hex-1-en-1-yl)borate (40, 0.244 $\mathrm{g}, 1.28 \mathrm{mmol}, 35 \%$ yield) was then collected by filtration and dried under vacuum.

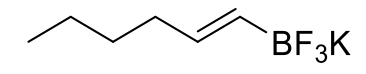

${ }^{1} \mathbf{H}$ NMR $\left(400 \mathrm{MHz}\right.$, Acetonitrile- $\left.d_{3}\right) \delta 5.62(\mathrm{dq}, J=12.6,6.0 \mathrm{~Hz}, 1 \mathrm{H}$, $\mathrm{BCH}=\mathrm{CH}), 5.30(\mathrm{dqd}, J=17.6,3.7,1.8 \mathrm{~Hz}, 1 \mathrm{H}, \mathrm{BCH}=\mathrm{CH}), 1.99-1.94$ $\left(\mathrm{m}, 2 \mathrm{H}, \mathrm{CH}-\mathrm{CH}_{2}\right), 1.37-1.24\left(\mathrm{~m}, 4 \mathrm{H}, \mathrm{CH}_{2} \mathrm{CH}_{2}\right), 0.89\left(\mathrm{~m}, 3 \mathrm{H}, \mathrm{CH}_{3}\right)$. The ${ }^{1} \mathrm{H}$ NMR data corresponds to the reported literature data. ${ }^{25}$
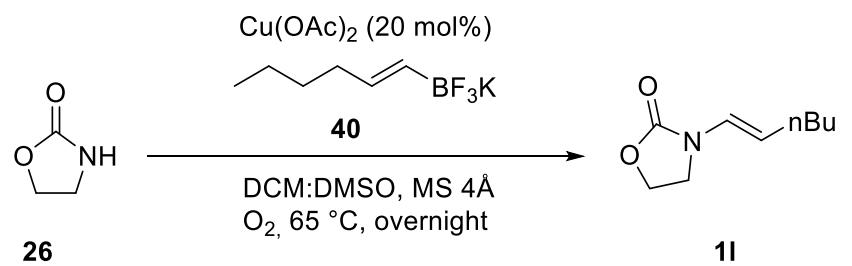

\footnotetext{
24 Perner, R. J.; Lee, C.-H.; Jiang, M., Gu, Y.-G., DiDomenico, S.; Bayburt, E. K.; Alexander, K. M.; Kohlhaas, K. L.; Jarvis, M. F.; Kowaluk, E., L.; Bhagwat, S. S. Bioorg. Med. Chem. Lett. 2005, 15, 2803.

${ }^{25}$ Batey R. A.; Thadani, A. N.; Smil, D. V. Org. Lett. 1999, 1, 1683.
} 
Following a reported procedure ${ }^{26}$ in a sealed $5.0 \mathrm{~mL}$ round bottomed test tube, potassium $(E)$ trifluoro(hex-1-en-1-yl)borate 40 (0.244 g, $1.28 \mathrm{mmol}, 1.7$ equiv), oxazolidin-2-one (0.066 g, $0.76 \mathrm{mmol}, 1.0$ equiv), and copper(II) acetate $(0.027 \mathrm{~g}, 0.15 \mathrm{mmol}, 0.20$ equiv) were dissolved in a mixture of $\mathrm{CH}_{2} \mathrm{Cl}_{2}(\mathrm{dry} ; 1.5 \mathrm{~mL})$ and DMSO (dry; $\left.1.5 \mathrm{~mL}\right)$ in the presence of MS $\left(4 \AA_{;} ; 0.60 \mathrm{~g}\right)$. The resulting blue suspension was stirred overnight at $65^{\circ} \mathrm{C}$ under an atmosphere of oxygen (balloon). After 20 hours, it was allowed to cool down to room temperature and filtered through a plug of celite, which was then washed with several portions of EtOAc. The resulting filtrate was concentrated under reduced pressure and submitted to column chromatography (still retaining DMSO) $\left(\mathrm{SiO}_{2}\right.$; EtOAc in pentane 5 to 20\%). (E)-3-(Hex-1-en-1-yl)oxazolidin-2one (1 ka, $0.081 \mathrm{~g}, 0.48 \mathrm{mmol}, 63 \%$ yield) was obtained as a colorless oil.

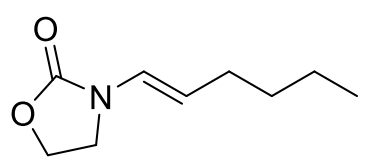
${ }^{1} \mathbf{H}$ NMR $(400 \mathrm{MHz}$, Chloroform-d) $\delta 6.64(\mathrm{~d}, J=14.3 \mathrm{~Hz}, 1 \mathrm{H}$, $\mathrm{NCH}=\mathrm{CH}-), 4.80(\mathrm{dt}, J=14.2,7.1 \mathrm{~Hz}, 1 \mathrm{H}, \mathrm{NCH}=\mathrm{CH}-), 4.42(\mathrm{~m}, 2 \mathrm{H}$, $\mathrm{CH}_{2}$ in the oxazolidinone cycle), $3.72-3.60\left(\mathrm{~m}, 2 \mathrm{H}, \mathrm{CH}_{2}\right.$ in the oxazolidinone cycle), 2.06 (qd, $\left.J=7.1,1.4 \mathrm{~Hz}, 2 \mathrm{H}, \mathrm{CH}=\mathrm{CHCH}_{2}\right), 1.44$ - $1.26\left(\mathrm{~m}, 4 \mathrm{H}, \mathrm{CH}_{2} \mathrm{CH}_{2}\right), 0.90\left(\mathrm{t}, J=7.1 \mathrm{~Hz}, 3 \mathrm{H}, \mathrm{CH}_{3}\right)$.

${ }^{13}$ C NMR (101 MHz, Chloroform-d) $\delta$ 155.4, 123.8, 111.4, 62.1, 42.6, 32.2, 29.4, 22.1, 13.9. The characterisation data corresponds to the reported literature data. ${ }^{26}$

(Z)-3-(hex-1-en-1-yl)oxazolidine-2-one (3I')

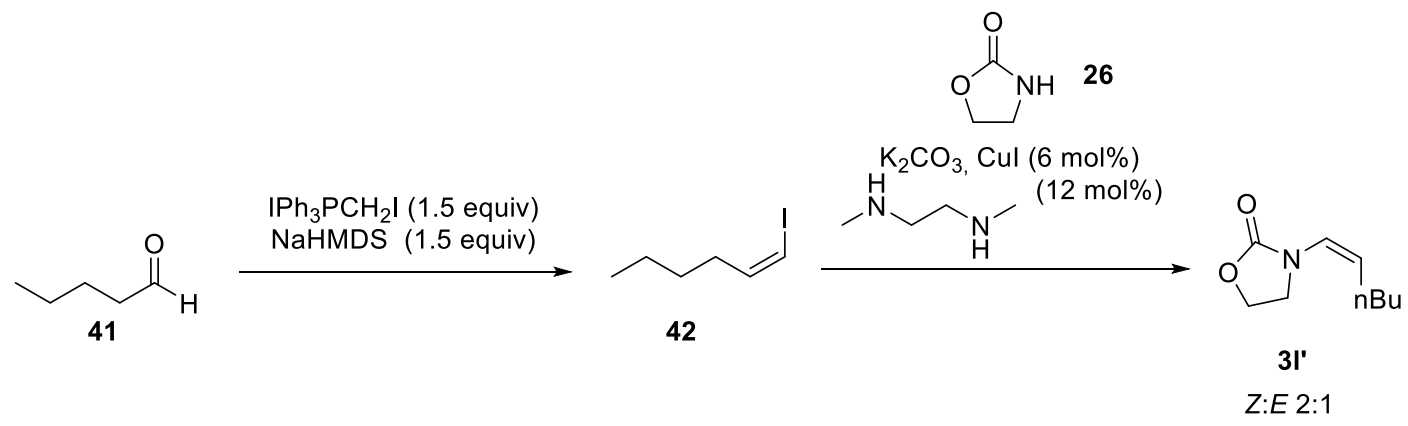

Following a reported procedure, ${ }^{27}$ under nitrogen atmosphere, iodo(iodomethyl)triphenylphosphorane $(5.16 \mathrm{~g}, 9.25 \mathrm{mmol}$ ) was suspended in THF (13 mL). At room temperature, sodium bis(trimethylsilyl)amide ( $2 \mathrm{M}$ in THF, $4.6 \mathrm{~mL}, 9.3 \mathrm{mmol}, 1.5$ equiv) was added dropwise over $5 \mathrm{~min}$. The reaction was stirred for $30 \mathrm{~min}$ then cooled to $-78^{\circ} \mathrm{C}$. A solution of valeraldehyde $(\mathbf{4 1}, 0.658 \mathrm{~mL}, 6.16 \mathrm{mmol}, 1.0$ equiv) in THF (13 mL) was added dropwise over $15 \mathrm{~min}$. The reaction was then stirred at $-78{ }^{\circ} \mathrm{C}$ for $1 \mathrm{~h}$ then quenched with ammonium chloride $(0.561 \mathrm{~g}, 10.5 \mathrm{mmol})$ dissolved in $10 \mathrm{~mL}$ water then warmed to RT. The crude was diluted with $\mathrm{Et}_{2} \mathrm{O}(20 \mathrm{~mL})$ and brine:water $(1: 1,20 \mathrm{~mL})$. The layers were separated, the aqueous layers were extracted with $\mathrm{Et}_{2} \mathrm{O}(5 \times 30 \mathrm{~mL})$. The organic layer was washed with $\mathrm{NaHCO}_{3}$ sat $(2 * 20 \mathrm{~mL})$, then brine $(20 \mathrm{~mL})$. The organic layers were combined and concentrated under reduced pressure. The compound was purified by column chromatography: $\mathrm{SiO}_{2}$ using pentane affording (Z)-1-iodohex-1-ene $(\mathbf{4 2}, 0.830 \mathrm{~g}, 3.95 \mathrm{mmol}, 64 \%$ yield). The later was used directly in the next step. Following a reported literature procedure, an oven-dried pointed 2 $\mathrm{mL}$ microwave vial was charged with oxazolidin-2-one $(\mathbf{2 6}, 0.237 \mathrm{~g}, 2.72 \mathrm{mmol}, 1$ equiv) and

\footnotetext{
26 Bolshan, Y.; Batey, R. Angew. Chem. Int. Ed. 2008, 47, 2109.

27 Selter, L. Harms, K.; Koert, U. Eur. J. Org. Chem. 2017, 1215.
} 
potassium carbonate $(0.414 \mathrm{~g}, 2.99 \mathrm{mmol}, 1.2$ equiv). Under the inert atmosphere of a glove box copper(l) iodide $(0.036 \mathrm{~g}, 0.19 \mathrm{mmol}, 6 \mathrm{~mol} \%)$ was added and the vial was sealed. $N_{,} N^{\prime}-$ dimethylethylenediamine $(0.041 \mathrm{~mL}, 0.38 \mathrm{mmol}, 12 \mathrm{~mol} \%)$ and a solution of (Z)-1-iodohex-1ene $(0.80 \mathrm{~g}, 3.8 \mathrm{mmol}, 1.4$ equiv) in anhydrous toluene $(0.9 \mathrm{~mL})$ were added via syringe. The resulting greenish suspension was stirred at $110-115^{\circ} \mathrm{C}$ for 20 hours. The solution colored a darkish orange. The crude was filtered over a celite pad and washed with $\mathrm{CH}_{2} \mathrm{Cl}_{2}$. The crude oil was submitted to column chromatography ( $\mathrm{SiO}_{2}$; EtOAc in pentane, 24/1 to 80/20) to afford 3-(hex-1-en-1-yl)oxazolidin-2-one as a mixture of $Z$ and $E$ isomers ( $\mathbf{3 l}$ ' and $\mathbf{3 l}, 0.340 \mathbf{g}, 0.200$ mmol, 74\% yield, Z:E ratio 2:1)

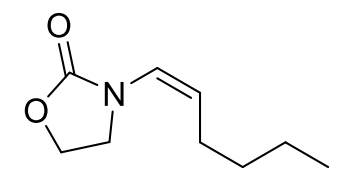

Characterisation of the $\mathrm{Z}: \mathrm{E}$ mixture :

Rf (pentane :EtOAc $6: 4)=0.4$.

${ }^{1} \mathbf{H}$ NMR (400 MHz, Benzene- $d_{6,}, 2: 1$ mixture of $(Z)$ in bold and $(E)$ alkene in italic) $\delta 7.01-6.78(\mathrm{~m}$, $0.5 \mathrm{H}, \mathrm{RCH}=\mathrm{CHR},(E)$-isomer), $6.44(\mathrm{dt}, J=9.7,1.6 \mathrm{~Hz}, 1 \mathrm{H}, \mathrm{RCH}=\mathrm{CHR},(Z)$-isomer), $4.46(\mathrm{dt}, J=9.7,7.6$ $\mathrm{Hz}, 1 \mathrm{H}, \mathrm{RCH}=\mathrm{CHR},(Z)$-isomer), 4.32 (dd, $J=14.3,7.1 \mathrm{~Hz}, 0.5 \mathrm{H}, \mathrm{RCH}=\mathrm{CHR},(E)$-isomer), 3.48 - 3.01 (m, $3 \mathrm{H}$, cyclic- $\mathrm{CH}_{2}(E)$-isomer + (Z)-isomer), $2.85-2.58\left(\mathrm{~m}, 2 \mathrm{H}\right.$, cyclic- $\mathrm{CH}_{2}$ (Z)-isomer $), 2.45-2.28(\mathrm{~m}$, $1 \mathrm{H}$, cyclic- $\mathrm{CH}_{2}(E)$-isomer), 1.87 (tdt, $J=7.1,4.4,1.5 \mathrm{~Hz}, 1 \mathrm{H}$, allylic- $\mathrm{CH}_{2},(E)$-isomer), 1.81 (tdt, $J=7.4$, 5.8, $1.7 \mathrm{~Hz}, 2 \mathrm{H}$, allylic- $\mathrm{CH}_{2}$ (Z)-isomer), $1.30-1.20\left(\mathrm{~m}, 2 \mathrm{H}, \mathrm{CH}_{2}-\mathrm{CH}_{2}-\mathrm{CH}_{3}\right.$ (E)-isomer), $1.19(\mathrm{~m}, 4 \mathrm{H}$, $\mathrm{CH}_{2}-\mathrm{CH}_{2}-\mathrm{CH}_{3}$ (Z)-isomer), $\mathbf{0 . 9 3} \mathbf{- 0 . 8 1}\left(\mathrm{m}, 2+3 \mathrm{H}, \mathrm{CH}_{3},(E)\right.$-isomer + (Z)-isomer). ${ }^{13} \mathbf{C} \mathbf{~ N M R}(101 \mathrm{MHz}$, Benzene- $d_{6}$, the $C=O$ of $(E)$-isomer is not resolved) $\delta 156.9,125.5,123.9,113.3,110.3,61.9,61.8,45.3$, 42.4, 33.4, 33.4, 30.3, 26.8, 23.1, 23.0, 14.7. IR $\left(\nu_{\text {max }} \mathrm{cm}^{-1}\right) 2959(\mathrm{~m}), 2931(\mathrm{~m}), 2871(\mathrm{~m}), 1752(\mathrm{~s}), 1415$ (s), $1243(\mathrm{~m}), 1094(\mathrm{~s}), 1075$ (s), 1040 (m). HRMS (nanochip-ESI/LTQ-Orbitrap) m/z: [M + H] ${ }^{+}$Calcd for $\mathrm{C}_{9} \mathrm{H}_{16} \mathrm{NO}_{2}{ }^{+}$170.1176; Found 170.1177 .

(E)-((hex-1-en-1-yloxy)methyl)benzene

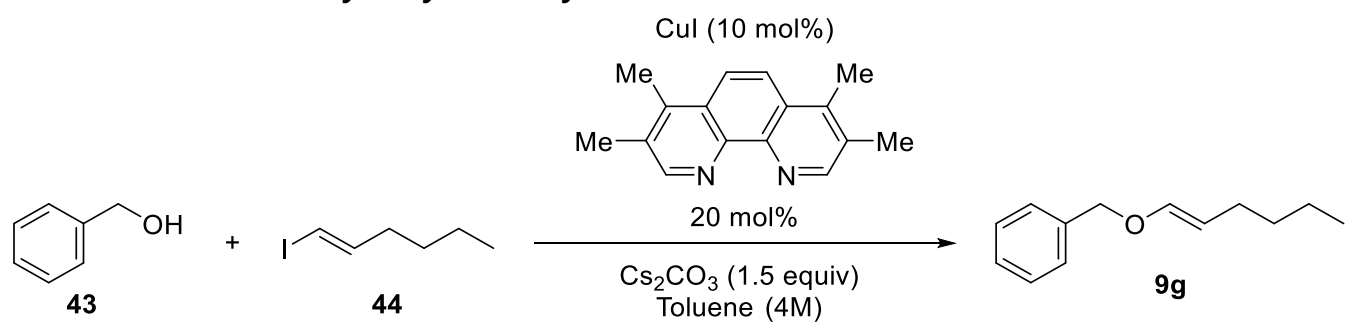

Following a slightly modified reported procedure, ${ }^{28}$ inside a glove box, a $5 \mathrm{~mL}$ test tube was charged with Cul $(0.038 \mathrm{~g}, 0.10 \mathrm{mmol}, 10 \mathrm{~mol} \%)$, 3,4,7,8-tetramethyl-1,10-phenanthroline (0.94.6 mg, $0.200 \mathrm{mmol}, 20 \mathrm{~mol} \%$ ) and $\mathrm{Cs}_{2} \mathrm{CO}_{3}(0.977 \mathrm{~g}, 3.00 \mathrm{mmol}, 1.5$ equiv). The tube was sealed and withdrawn from the glovebox. Toluene (dry, $1.0 \mathrm{~mL}$ ), followed by benzyl alcohol (43, $0.41 \mathrm{~mL}, 2.0 \mathrm{mmol}, 2$ eq.) and $E$-1-iodohexene $(\mathbf{4 4}, 0.210 \mathrm{~g}, 1.00 \mathrm{mmol}, 1$ equiv) were then added via syringe. The reaction mixture was heated to $80^{\circ} \mathrm{C}$ for 8 hours. After this time TLC analysis showed full consumption of the iodo-alkene. The reaction was stopped, the now brown suspension was allowed to cool down to room temperature, and the solids were then filtered off through a short pad of $\mathrm{SiO}_{2}$, which was washed with several portions of $\mathrm{CH}_{2} \mathrm{Cl}_{2}$. The

\footnotetext{
${ }^{28}$ Nordmann, G.; Buchwald, S. L. J. Am. Chem. Soc. 2003, 125, 4978.
} 
resulting brown-orange solution was concentrated under reduced pressure. The so obtained brown crude oil was submitted to column chromatography (Biotage, $12 \mathrm{~g} \mathrm{SiO}_{2} ; \mathrm{CH}_{2} \mathrm{Cl}_{2}$ in pentane, 1 to $10 \%)$ to afford (E)-((hex-1-en-1-yloxy)methyl)benzene $(\mathbf{9 g}, 0.253 \mathrm{~g}, 1.32 \mathrm{mmol}$, $66 \%$ yield) as a colorless oil.

Rf (pentane: $\mathrm{CH}_{2} \mathrm{Cl}_{2}$ 96:4) $=0.6$.

${ }^{1} \mathbf{H}$ NMR (400 MHz, Chloroform-d) $\delta 7.40-7.34(\mathrm{~m}, 4 \mathrm{H}, \mathrm{PhH})$, $7.31(\mathrm{~m}, 1 \mathrm{H}, \mathrm{PhH}), 6.34(\mathrm{dt}, J=12.5,1.4 \mathrm{~Hz}, 1 \mathrm{H}, \mathrm{OCH}=\mathrm{CH}-)$, $4.90(\mathrm{dt}, J=12.5,7.3 \mathrm{~Hz}, 1 \mathrm{H}, \mathrm{OCH}=\mathrm{CH}-), 4.72\left(\mathrm{~s}, 2 \mathrm{H}, \mathrm{PhCH}_{2} \mathrm{O}\right)$, $1.94\left(\mathrm{dtt}, J=8.5,7.2,1.4 \mathrm{~Hz}, 2 \mathrm{H}, \mathrm{CH}=\mathrm{CHCH}_{2}\right), 1.40-1.25(\mathrm{~m}$, $\left.4 \mathrm{H}, \mathrm{CH}_{2} \mathrm{CH}_{2}\right), 0.90\left(\mathrm{~m}, 3 \mathrm{H}, \mathrm{CH}_{3}\right)$.

${ }^{13}$ C NMR (101 MHz, Chloroform-d) $\delta 145.8,137.4,128.5,127.8,127.6,105.3,71.1,32.8,27.4$, 22.1, 13.9. IR $\left(\nu_{\max } \mathrm{cm}^{-1}\right) 3011(\mathrm{~m}), 2998(\mathrm{~m}), 2970(\mathrm{~s}), 2955(\mathrm{~s}), 2923(\mathrm{~s}), 2902(\mathrm{~s}), 2850(\mathrm{~m})$, $1672(\mathrm{~m}), 1455(\mathrm{~m}), 1380(\mathrm{~m}), 1258(\mathrm{~m}), 1213(\mathrm{~s}), 1153(\mathrm{~s}), 1124(\mathrm{~s}), 1075(\mathrm{~s}), 1046(\mathrm{~s}), 1038$ (s). HRMS (APPI/LTQ-Orbitrap) m/z: [M + H] $]^{+}$Calcd for $\mathrm{C}_{13} \mathrm{H}_{19} \mathrm{O}^{+}$191.1430; Found 191.1433. 


\section{Ene-carbamate and enol-ether oxyalkynylation}

Optimisation of the reaction conditions and control reactions:
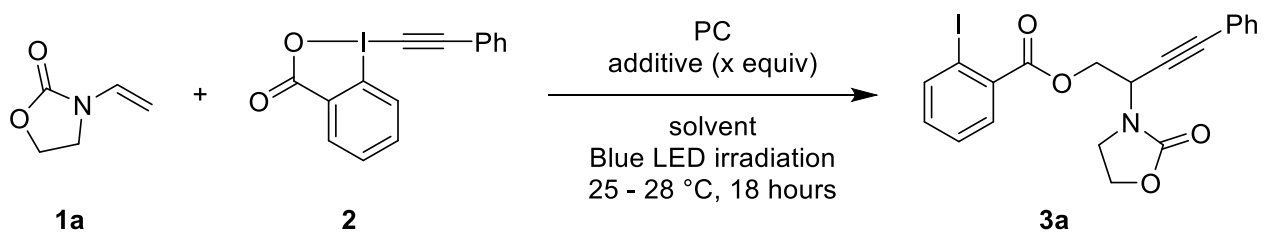

$3 \mathbf{a}$

An oven-dried screw-top vial was charged with PC (5 $\mu$ mol, 5 mol\%), PhEBX (2, 0.10 mmol, 1.0 equiv) and additive (X equiv). After 3 vacuum/ $\mathrm{N}_{2}$ cycles, dry degassed (via freeze-pump-thaw technique) solvent was added (1.1 mL, $0.097 \mathrm{M}$; unless specified) followed by 1a (1.2 equiv). The reaction was sealed under a flow of Argon and the reaction vessel was placed under irradiation (blue leds) and stirred overnight (18 hours). After this time, the conversion of PhEBX could be observed by TLC analysis (Pent:EtOAC, 7:3, p-anisaldehyde stain, blue-green spot). The reaction mixture was concentrated under reduced pressure. $\mathrm{CH}_{2} \mathrm{Br}_{2}(7 \mu \mathrm{L}, 1.0$ equiv) were added as an internal standard and the crude was solubilised immediately in Chloroform- $d$.

$\left[\operatorname{lr}\left(\mathrm{dF}\left(\mathrm{CF}_{3}\right) \mathrm{ppy}\right)_{2}(\mathrm{tbbpy})\right] \mathrm{PF}_{6}: \mathbf{2 6}$

$\left[\mathrm{Ru}(\mathrm{bpy})_{3}\right]\left(\mathrm{PF}_{6}\right)_{2}: \mathbf{2 7}$

Table 1: Optimisation of the reaction conditions

\begin{tabular}{|c|c|c|c|c|c|}
\hline entry & PC & Additive (x eq.) & Solvent (M) & yield (\%) & comments \\
\hline 1 & $4 a$ & None & DCE & 30 & \\
\hline 2 & $4 b$ & None & DCE & 42 & \\
\hline 3 & 5 & None & DCE & 5 & \\
\hline 4 & $4 b$ & None & DCE & $36-65$ & \\
\hline $5^{b}$ & $4 b$ & None & DCE & 34 & Recrystalised Ph-EBX \\
\hline 6 & $4 b$ & $\mathrm{BIOH} 6$ (1.5 eq.) & DCE $(0.1 \mathrm{M})$ & 46 & Recrystalised Ph-EBX \\
\hline 7 & $4 b$ & BIOAc 7 (1.5 eq.) & DCE $(0.1 \mathrm{M})$ & 70 & Recrystalised Ph-EBX \\
\hline 8 & $4 b$ & BIOAc 7 (1.5 eq.) & DCE $(0.1 \mathrm{M})$ & 20 & $\begin{array}{l}\text { With } \\
\text { instead of } \mathbf{2}\end{array}$ \\
\hline 9 & $4 b$ & BIOAc 7 (1.0 eq.) & DCE $(0.1 \mathrm{M})$ & 73 & Recrystalised Ph-EBX \\
\hline 10 & $4 b$ & BIOAc 7 (0.5 eq.) & DCE $(0.1 \mathrm{M})$ & 75 & Recrystalised Ph-EBX \\
\hline 11 & $4 b$ & BIOAc 7 (0.5 eq.) & DMSO (0.1 M) & 75 & Recrystalised Ph-EBX \\
\hline 12 & $4 b$ & BIOAC 7 (0.5 eq.) & $\mathrm{CH}_{2} \mathrm{Cl}_{2}(0.1 \mathrm{M})$ & 80 & Recrystalised Ph-EBX \\
\hline 13 & $4 b$ & BIOAc 7 (0.5 eq.) & $\mathrm{CH}_{2} \mathrm{Cl}_{2}(0.25 \mathrm{M})$ & 80 & Recrystalised Ph-EBX \\
\hline 14 & $4 b$ & BIOAc 7 (0.5 eq.) & $\mathrm{CH}_{2} \mathrm{Cl}_{2}(0.5 \mathrm{M})$ & 80 & Recrystalised Ph-EBX \\
\hline 15 & $4 b$ & BIOAc 7 (0.5 eq.) & $\mathrm{CH}_{2} \mathrm{Cl}_{2}(0.25 \mathrm{M})$ & 80 & $\begin{array}{l}\text { Recrystalised Ph-EBX, } \mathbf{4 b}: 2 \text { mol\% } \mathbf{1} \mathbf{a} \\
\text { (1.5 equiv) }\end{array}$ \\
\hline 16 & $4 b$ & BIOAc 7 (0.5 eq.) & $\mathrm{CH}_{2} \mathrm{Cl}_{2}(0.25 \mathrm{M})$ & 80 & $\begin{array}{l}\text { Recrystalised Ph-EBX, } \mathbf{4 b}: 2 \text { mol\%, } 1 \mathbf{a} \\
\text { (1.5 equiv) }\end{array}$ \\
\hline 17 & 8 & BIOAC 7 (0.5 eq.) & $\mathrm{CH}_{2} \mathrm{Cl}_{2}(0.25 \mathrm{M})$ & 21 & $\begin{array}{l}\text { Recrystalised Ph-EBX, 7: } 2 \text { mol\%1a } \\
\text { (1.5 equiv) }\end{array}$ \\
\hline 18 & 26 & BIOAc 7 (0.5 eq.) & $\mathrm{CH}_{2} \mathrm{Cl}_{2}(0.25 \mathrm{M})$ & 24 & $\begin{array}{l}\text { Recrystalised Ph-EBX, 26: } 2 \text { mol\%1a } \\
\text { (1.5 equiv) }\end{array}$ \\
\hline 19 & $4 b$ & BIOAc 7 (0.05 eq.) & $\mathrm{CH}_{2} \mathrm{Cl}_{2}(0.25 \mathrm{M})$ & 80 & $\begin{array}{l}\text { Recrystalised Ph-EBX, 4b: } 2 \text { mol\%1a } \\
\text { (1.5 equiv) }\end{array}$ \\
\hline
\end{tabular}


Table 2: Control experiments

\begin{tabular}{|c|c|c|c|c|c|}
\hline entry & PC & Additive (x eq.) & $\begin{array}{l}\text { Solvent } \\
\text { (M) }\end{array}$ & yield (\%) & comments \\
\hline 1 & 4b & BIOAC 7 ( 0.5 eq.) & DCE & - & No light \\
\hline 2 & - & BIOAC 7 (0.5 eq.) & DCE & - & Light, no conversion observed \\
\hline 3 & - & BIOAC 7 (0.5 eq.) & DCE & - & No light \\
\hline 4 & 5 & BIOAC 7 (0.5 eq.) & $\mathrm{CH}_{2} \mathrm{Cl}_{2}$ & $10-15$ & $80 \%$ conversion of starting alkene \\
\hline 5 & 27 & BIOAC 7 (0.5 eq.) & $\mathrm{CH}_{2} \mathrm{Cl}_{2}$ & - & $\begin{array}{l}\text { Performed with 1c. No conversion } \\
\text { observed }\end{array}$ \\
\hline
\end{tabular}




\section{Electrochemical experiments}

An Autolab potentiostat with a 3 electrode cell configuration: glassy carbon (working electrode), Pt wire as (control electrode), and $\mathrm{Ag} / \mathrm{AgCl}$ ( $\mathrm{KCl}, 3 \mathrm{M}$ aq.) as (reference electrode) was used for the measures. Tetrabutyl ammonium hexafluorophosphhate (TBAP, 0.1M in $\mathrm{MeCN})$ was used as an electrolyte. The sample $(0.01 \mathrm{mmol})$ was dissolved in a stock solution of TBAP $(0.1 \mathrm{M}, 10 \mathrm{~mL}$ in $\mathrm{MeCN})$ and was degassed by bubbling Argon directly before measure. The redox couple $E\left(\right.$ alkene ${ }^{+}$/alkene) is defined as the potential $E$ measured for $\frac{I_{\max }}{2}$.

\section{Cyclic voltagram of $1 \mathrm{a}$}

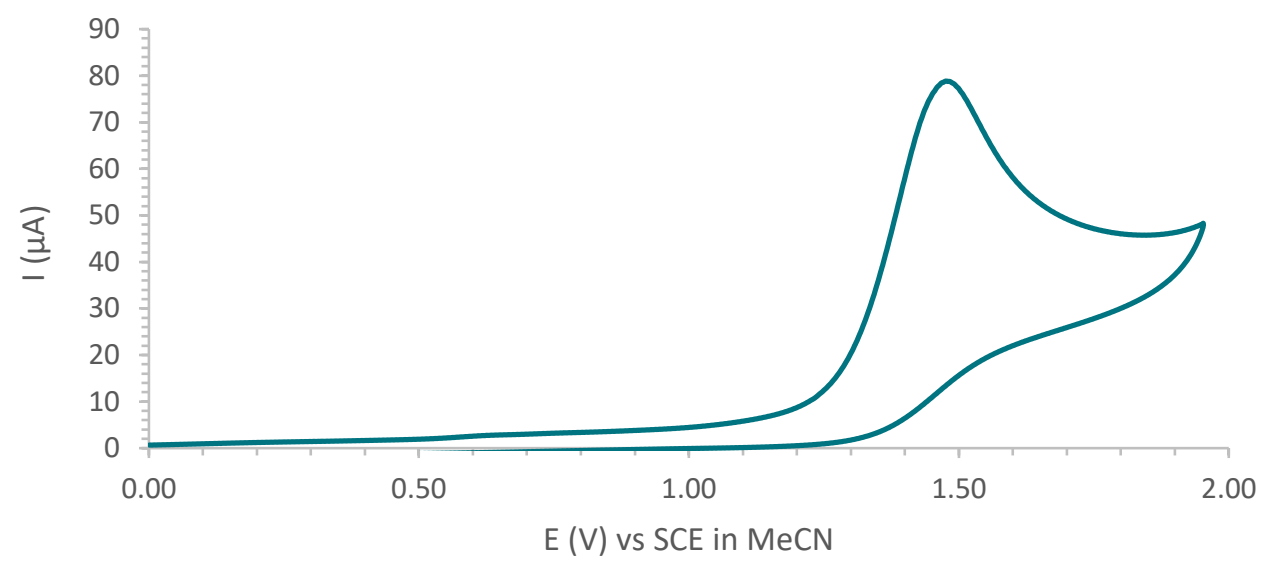

$$
\begin{gathered}
I_{\max }=78 \mu \mathrm{A} ; \frac{I_{\max }}{2}=39 \mu \mathrm{A} ; \mathrm{E}=1.30 \mathrm{~V} \text { so that } \mathrm{I}=39 \mu \mathrm{A} \\
\mathrm{E}\left(\mathbf{1} \mathbf{a}^{+\bullet} / \mathbf{1 a}\right)=+1.30 \mathrm{~V}
\end{gathered}
$$

\section{Cyclic voltagram of $1 \mathbf{c}$}

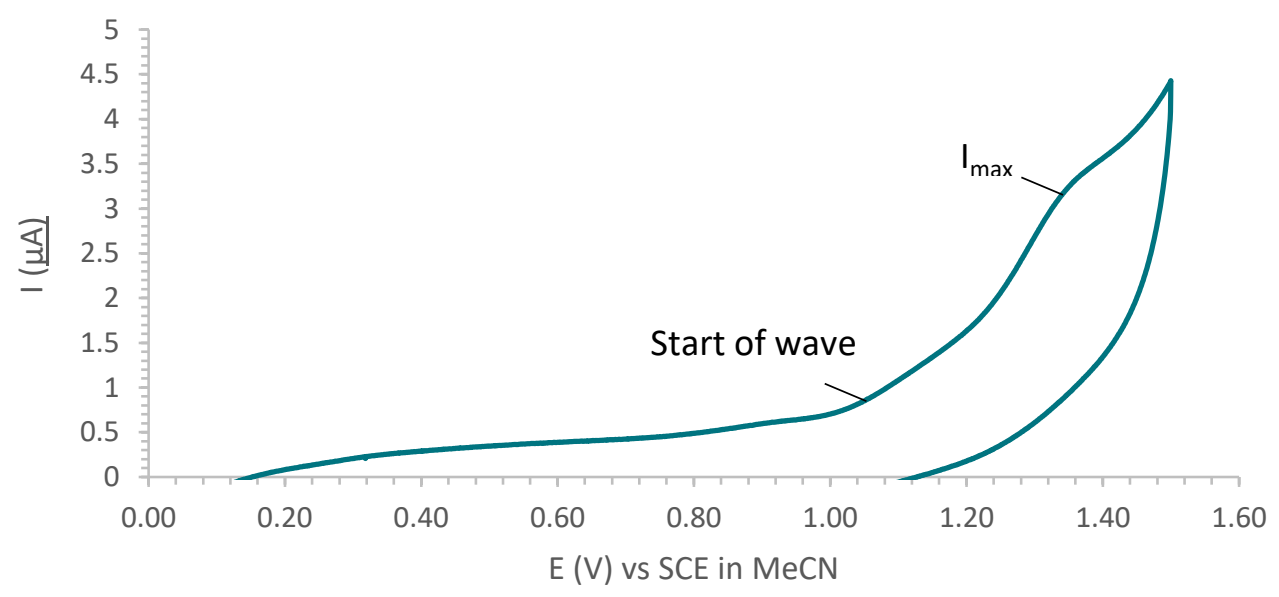

$$
\begin{gathered}
I_{\text {max }}=3.24 \mu A ; I_{\text {start of } \text { wave }}=0.78 \mu A ; \frac{I_{\text {max }}-I_{\text {start of wave }}}{2}=2.46 \mu A ; \\
E=1.28 \mathrm{~V} \text { so that } \mathrm{I}=2.46 \mu \mathrm{A} \\
\mathrm{E}\left(\mathbf{1} \mathbf{c}^{+\bullet} / \mathbf{1} \mathbf{c}\right)=+1.28 \mathrm{~V}
\end{gathered}
$$




\section{Cyclic voltagram of $\mathbf{1 k}$}

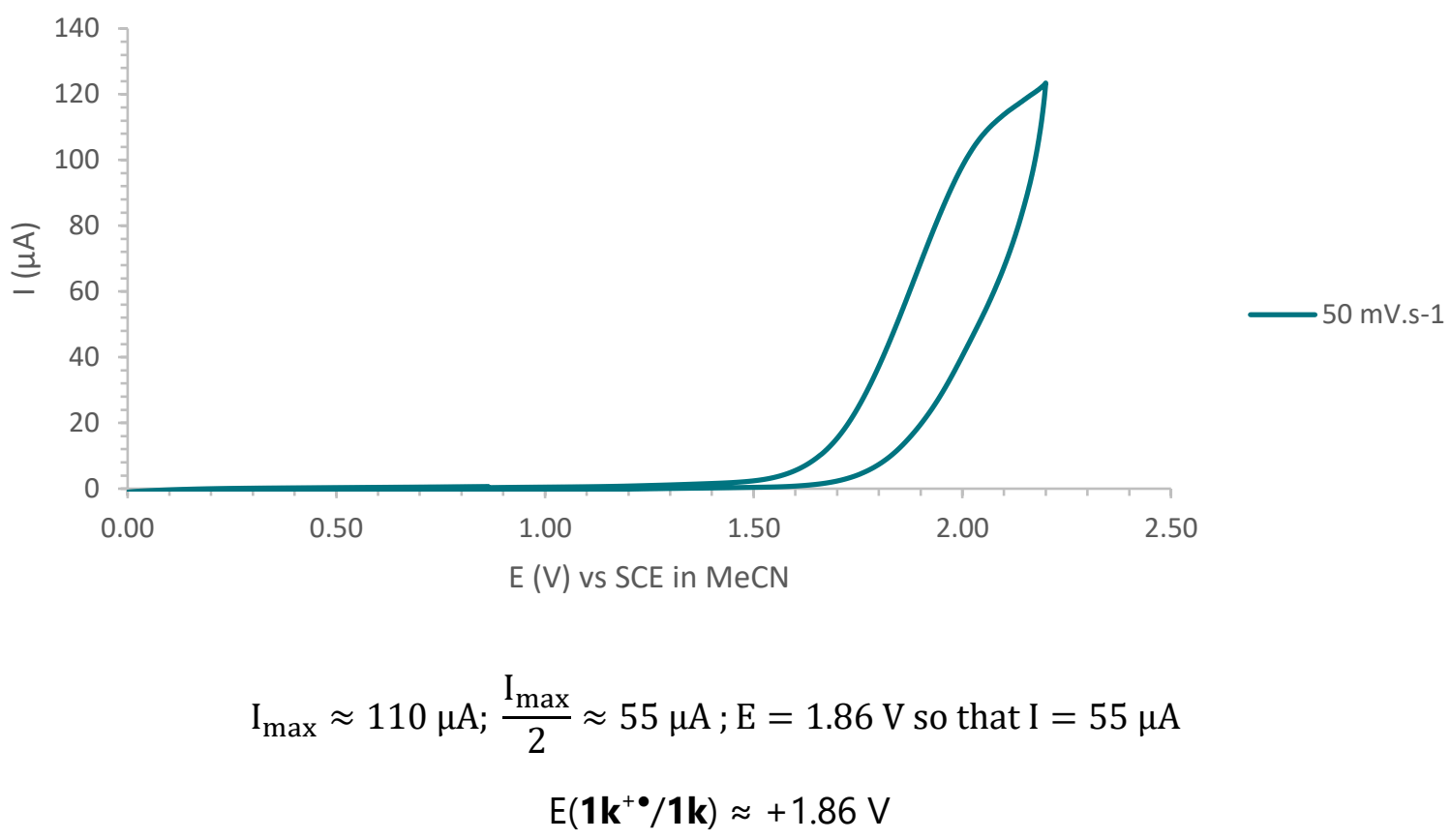


Experimental set-up

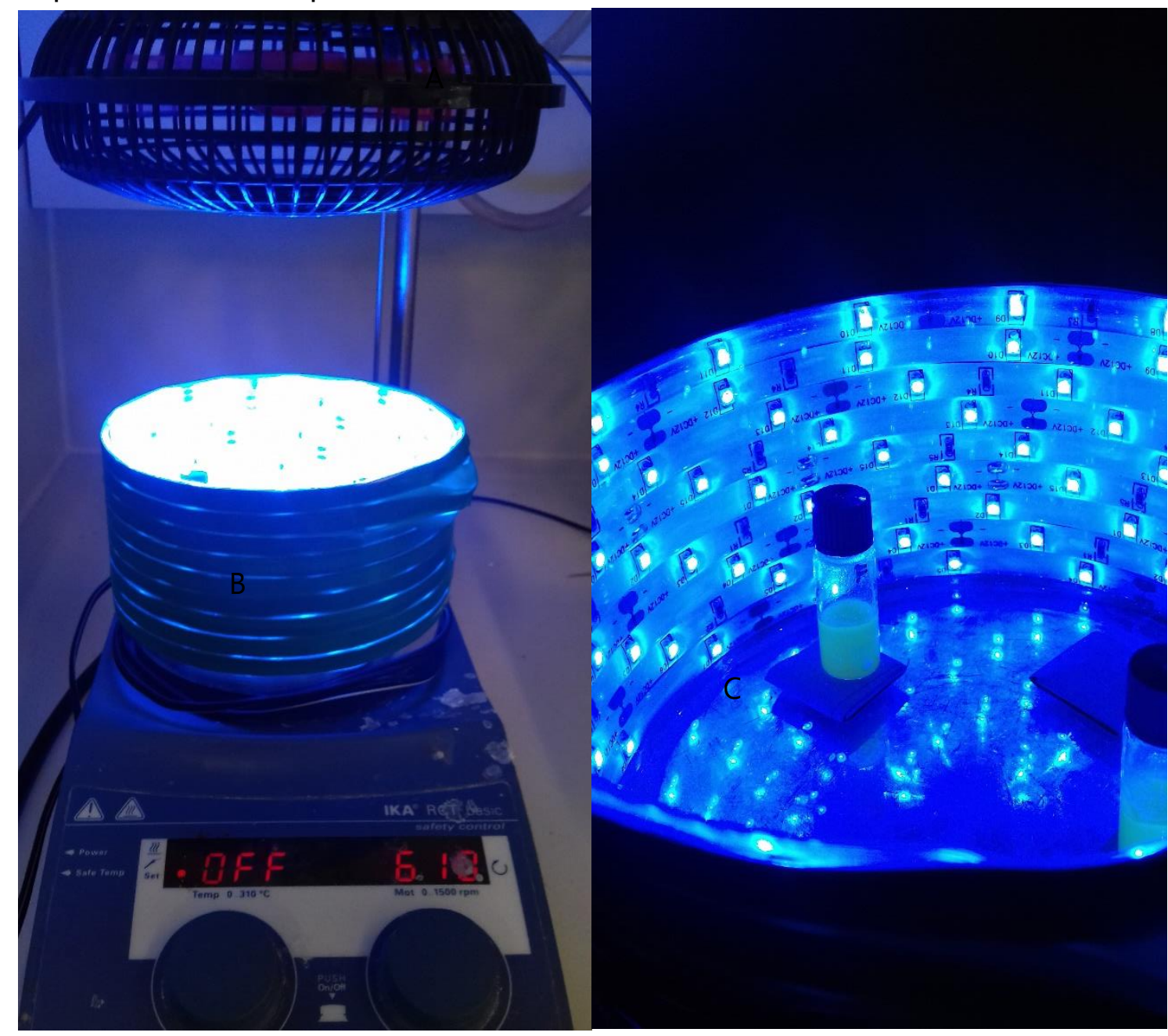

A : Overtop ventilation, B : crystalisation bowl wrapped with LEDs. C flask stuck to bottom of crystalisation bowl ca. $3 \mathrm{~cm}$ away from LEDs. The whole set up is concealed from the external light sources with a reflective shield. 
General procedure for scope scale reactions:

An oven-dried flat-bottomed screw-cap vial equipped with a magnetic stirrer was charged with R-EBX ( $0.25 \mathrm{mmol}, 1.0$ equiv), BIOAC $(0.13 \mathrm{mmol}, 0.5$ equiv) and $4-C I C Z I P N(\mathbf{4 b}, 5 \mathrm{mg}, 5$ $\mu \mathrm{mol}, 2 \mathrm{~mol} \%)$. The reaction vessel was sealed with a rubber septum. Following three vacuum/nitrogen cycles, dry, degassed (via freeze-pump-thaw technique) $\mathrm{CH}_{2} \mathrm{Cl}_{2}(0.25 \mathrm{M}$ based on R-EBX, $1.0 \mathrm{~mL}$ ) was then added. The substrate $(0.38 \mathrm{mmol}, 1.5 \text { equiv })^{29}$ was then added via syringe. The rubber septum was replaced with the corresponding screw-cap under a flux of Argon. The reaction was irradiated overnight (15 h-18 h) with blue LED strips under ventilation $\left(T=25^{\circ} \mathrm{C}\right)$ and stirring. The volatiles were evaporated off. The crude was then dissolved in $\mathrm{CH}_{2} \mathrm{Cl}_{2}$ with $0.2 \mathrm{~mL}$ of $\mathrm{Et}_{3} \mathrm{~N}$. A solid deposit for flash chromatography was prepared with $\mathrm{SiO}_{2}$ (ca. 3g). The crude was then purified though flash chromatography ( $\mathrm{Et}{ }_{3} \mathrm{~N}$ deactivated $\mathrm{SiO}_{2}$ ca. $40 \mathrm{~g}$ or biotage : $\mathrm{SiO}_{2} 25 \mathrm{~g}$, Pentane:Et $\mathrm{t}_{2} \mathrm{O}$ or Pentane:EtOAc) ${ }^{30}$ affording the desired difunctionalised product.

\section{Characterisation data}

2-(2-Oxooxazolidin-3-yl)-4-phenylbut-3-yn-1-yl 2-iodo benzoate (3a)<smiles>O=C(OCC(C#Cc1ccccc1)N1CCOC1=O)c1ccccc1I</smiles>
Performed on $0.2 \mathrm{mmol}$ scale. Obtained from $N$-vinyloxazolidin-2-one $(1 \mathbf{a}, 0.027 \mathrm{~g}, 0.24 \mathrm{mmol}$, 1.5 equiv); $\operatorname{PhEBX}(\mathbf{2}, 0.070 \mathrm{~g}, 0.20 \mathrm{mmol}, 1.0$ equiv); $\operatorname{BIOAc}(\mathbf{7}, 0.031$ g, $0.10 \mathrm{mmol}, 0.5$ equiv) and 4-CICzIPN (4b, 4 mg, 4 Hmol, 2 mol\%); $\mathrm{CH}_{2} \mathrm{Cl}_{2}(0.8 \mathrm{~mL}, 0.25 \mathrm{M})$ after 18 hours.

Column: Pentane:EtOAc, 9:1 to 8:2. Yield $80 \%(0.074 \mathrm{~g}, 0.16 \mathrm{mmol})$. Yellow oil with residual grease.

Rf (Pentane:EtOAc 8:2) $=0.3$.

${ }^{1} \mathbf{H}$ NMR $(400 \mathrm{MHz}$, Chloroform-d) $\delta 8.00(\mathrm{dd}, J=7.9,1.2 \mathrm{~Hz}, 1 \mathrm{H}, \mathrm{ArH}), 7.84(\mathrm{dd}, J=7.8,1.7 \mathrm{~Hz}, 1 \mathrm{H}$, $\mathrm{ArH}), 7.44(\mathrm{dd}, J=7.9,1.8 \mathrm{~Hz}, 2 \mathrm{H}, \mathrm{PhH}), 7.41(\mathrm{dd}, J=7.7,1.2 \mathrm{~Hz}, 1 \mathrm{H}, \mathrm{ArH}), 7.38-7.31(\mathrm{~m}, 3 \mathrm{H}, \mathrm{PhH})$, $7.17(\mathrm{ddd}, J=7.9,7.4,1.7 \mathrm{~Hz}, 1 \mathrm{H}, \mathrm{ArH}), 5.37(\mathrm{dd}, J=9.0,4.4 \mathrm{~Hz}, 1 \mathrm{H}, \mathrm{NCH}), 4.77$ (dd, $J=11.5,9.0 \mathrm{~Hz}$, $\left.1 \mathrm{H}, \mathrm{OCH}_{2}\right), 4.47\left(\mathrm{dd}, J=11.5,4.4 \mathrm{~Hz}, 1 \mathrm{H}, \mathrm{OCH}_{2}\right), 4.44-4.33\left(\mathrm{~m}, 2 \mathrm{H}, \mathrm{CH}_{2}\right), 3.85(\mathrm{dt}, J=9.2,8.1 \mathrm{~Hz}, 1 \mathrm{H}$, $\left.\mathrm{CH}_{2}\right), 3.78\left(\mathrm{td}, J=8.6,5.6 \mathrm{~Hz}, 1 \mathrm{H}, \mathrm{CH}_{2}\right) .{ }^{13} \mathrm{C}$ NMR $(101 \mathrm{MHz}$, Chloroform-d) $\delta 165.9,158.0,141.4,134.2$, 133.1, 131.9, 131.3, 129.2, 128.5, 128.2, 121.5, 94.3, 87.5, 80.9, 63.8, 62.4, 46.2, 41.2. IR $\left(\nu_{\text {max }} \mathrm{Cm}^{-1}\right) 3060$ (w), $2993(w), 2920(w), 2851(w), 2229(w), 1750(s), 1487(m), 1422(m), 1249(s)$. HRMS (ESI) calcd for $\mathrm{C}_{20} \mathrm{H}_{17} \mathrm{NNO}_{4}{ }^{+}[\mathrm{M}+\mathrm{H}]^{+}$462.0197; found 462.0206 .

2-((Tert-butoxycarbonyl)(phenethyl)amino)-4-phenylbut-3-yn-1-yl

2-iodobenzoate (3b)<smiles>O=C(OCC(C#Cc1ccccc1)N(CCc1ccccc1)C(=O)OCc1ccccc1)c1ccccc1I</smiles>

Performed on $0.2 \mathrm{mmol}$ scale. Obtained from tert-butyl phenethyl(vinyl)carbamate $(\mathbf{1} \mathbf{b}, 0.054 \mathrm{~g}$, $0.24 \mathrm{mmol}, 1.2$ equiv); $\operatorname{PhEBX}(\mathbf{2}, 0.070 \mathrm{~g}, 0.20 \mathrm{mmol}, 1.0$ equiv); $\operatorname{BIOAC}(\mathbf{7}, 0.031 \mathrm{~g}, 0.10 \mathrm{mmol}, 0.5$ equiv) and $4-\mathrm{ClCzIPN}$ (4b, $4 \mathrm{mg}$, $4 \mu \mathrm{mol}, 2 \mathrm{~mol} \%), \mathrm{CH}_{2} \mathrm{Cl}_{2}(0.8 \mathrm{~mL}, 0.25 \mathrm{M})$ after 18 hours. Column: Pentane:EtOAc, 1:0 to 9:1. Yield $63 \%(0.074 \mathrm{~g}, 0.12 \mathrm{mmol})$. Pale yellow oil.

\footnotetext{
${ }^{29}$ Some reactions were performed on $0.2 \mathrm{mmol}$ scale of PhEBX with 1.2 equiv of alkene.

${ }^{30}$ Coelution of residual alkene was often observed hence the greater quantities of $\mathrm{SiO}_{2}$. The corresponding dilution can lead to poor detection of the compound by TLC (both UV and panisaldehyde stains should be combined).
} 
Rf (Pent.:EtOAc 9:1) $=0.25$

${ }^{1} \mathbf{H}$ NMR $\left(400 \mathrm{MHz}\right.$, Acetonitrile- $d_{3}, 7: 3$ mixture of rotamers) $\delta 8.06(\mathrm{~d}, J=7.9 \mathrm{~Hz}, 1 \mathrm{H}, \operatorname{ArH}), 7.85(\mathrm{dd}$, $J=7.8,1.7 \mathrm{~Hz}, 1 \mathrm{H}, \mathrm{ArH}), 7.56-7.37(\mathrm{~m}, 6 \mathrm{H}, \mathrm{PhH}+\mathrm{ArH}), 7.33-7.19(\mathrm{~m}, 6 \mathrm{H}, \mathrm{PhH}+\mathrm{ArH}), 5.64(\mathrm{bs}, 0.7 \mathrm{H}$, major, $\mathrm{NCH}$ ), 5.37 (bs, 0.3H, minor, $\mathrm{NCH}), 4.55(\mathrm{~d}, J=6.9 \mathrm{~Hz}, 2 \mathrm{H}, \mathrm{OCH}), 3.66-3.43\left(\mathrm{~m}, 2 \mathrm{H}, \mathrm{CH}_{2}\right), 3.01$ $\left(\mathrm{dq}, J=12.5,7.5,6.9 \mathrm{~Hz}, 2 \mathrm{H}, \mathrm{CH}_{2}\right), 1.46\left(\mathrm{~s}, 9 \mathrm{H}, \mathrm{C}\left(\mathrm{CH}_{3}\right)_{3}\right) .{ }^{13} \mathrm{C}$ NMR $\left(101 \mathrm{MHz}\right.$, Acetonitrile- $d_{3}$, mixture of rotamers, signals not fully resolved) $\delta 172.0,166.2,142.0,135.3,133.7,132.2,131.6,129.6,129.2$, 128.8, 122.5, 94.0, 81.1, 65.0, 60.8, 47.6, 40.9, 35.1, 28.0, 14.1. IR ( $\left.\mathrm{V}_{\max }, \mathrm{cm}^{-1}\right) 2977(\mathrm{~s}), 2952(\mathrm{~m}), 1733$ (s), 1692 (s), 1403 (s), 1366 (s), 1247 (s), 1159 (s). HRMS (ESI/QTOF) m/z: [M + Na] ${ }^{+}$Calcd for $\mathrm{C}_{30} \mathrm{H}_{30} \mathrm{INNaO}_{4}{ }^{+}$618.1112; Found 618.1109.

2-(((Benzyloxy)carbonyl)(phenethyl)amino)-4-phenylbut-3-yn-1-yl 2-iodobenzoate (3c)<smiles>O=C(OCC(C#Cc1ccccc1)N(CCc1ccccc1)C(=O)O)c1ccccc1I</smiles>
Performed on $0.2 \mathrm{mmol}$ scale. Obtained from benzyl phenethyl(vinyl)carbamate $(\mathbf{1 c}, 0.068 \mathrm{~g}, 0.24$ mmol, 1.2 equiv); $\operatorname{PhEBX}(\mathbf{2}, 0.070 \mathrm{~g}, 0.2 \mathrm{mmol}, 1.0$ equiv); $\operatorname{BIOAc}(\mathbf{7}$, $0.031 \mathrm{~g}, 0.1 \mathrm{mmol}, 0.5$ equiv) and $4-\mathrm{CICzIPN}(\mathbf{4 b}, 4 \mathrm{mg}, 4 \mu \mathrm{mol}, 2$ mol\%) after 18 hours.

Column: Pentane:EtOAc, $10: 0$ to 9:1. Yield $86 \%(0.108 \mathrm{~g}, 0.172$ $\mathrm{mmol})$. Pale yellow oil.

Rf (Pent.:EtOAc 9:1) $=0.25$.

${ }^{1} \mathbf{H}$ NMR (400 MHz, Acetonitrile- $d_{3}, 6: 4$ mixture of rotamers) $\delta 8.01$ (dd, $J=8.0,1.2 \mathrm{~Hz}, 1 \mathrm{H}$, $\operatorname{ArH}), 7.75(\mathrm{~d}, J=7.7 \mathrm{~Hz}, 1 \mathrm{H}, \mathrm{ArH}), 7.61-7.07(\mathrm{~m}, 12 \mathrm{H}, \mathrm{PhH}), 5.62$ (bs, 0.6H, major, NCH), 5.48 (bs, 0.4H minor, $\mathrm{NCH}$ )., $5.12\left(\mathrm{~d}, J=3.7 \mathrm{~Hz}, 2 \mathrm{H}, \mathrm{OCH}_{2} \mathrm{Ph}\right), 4.58-4.51\left(\mathrm{~m}, 2 \mathrm{H}, \mathrm{CHCH}_{2} \mathrm{O}\right), 3.72-$ $3.47\left(\mathrm{~m}, 2 \mathrm{H}, \mathrm{CH}_{2} \mathrm{CH}_{2}\right), 3.12-2.90\left(\mathrm{~m}, 2 \mathrm{H}, \mathrm{CH}_{2} \mathrm{CH}_{2}\right) .{ }^{13} \mathrm{C}$ NMR $\left(101 \mathrm{MHz}\right.$, Acetonitrile- $d_{3,}$ mixture of rotamers, signals not fully resolved) $\delta 166.7,156.8,142.2,140.2,137.7,134.0$, 132.6, 131.8, 130.0, 129.7, 129.6, 129.4, 129.3, 128.9, 122.8, 94.3, 86.8, 84.5, 68.2, 65.5, 49.0, 47.4, 36.9, 35.9. IR $\left(v_{\max } \mathrm{cm}^{-1}\right) 3033(\mathrm{~m}), 3071(\mathrm{~m}), 2951(\mathrm{~m}), 2862(\mathrm{~m}), 1732(\mathrm{~s}), 1700(\mathrm{~s}), 1586$ $(\mathrm{m}), 1491(\mathrm{~m}), 1453(\mathrm{~s}), 1409(\mathrm{~s}), 1370(\mathrm{~m}), 1282(\mathrm{~s}), 1250(\mathrm{~s}), 1174(\mathrm{~m}), 1129(\mathrm{~s}), 1104(\mathrm{~s})$, $1047(\mathrm{~m}), 1015(\mathrm{~s}), 977(\mathrm{~m}), 742(\mathrm{~s}), 685$ (m), 691 (s). HRMS (ESI/QTOF) m/z: [M + Na] ${ }^{+}$Calcd for $\mathrm{C}_{33} \mathrm{H}_{28} \mathrm{INNaO}_{4}{ }^{+}$652.0955; Found 652.0961 .

2-(Benzyl(tert-butoxycarbonyl)amino)-4-phenylbut-3-yn-1-yl 2-iodobenzoate (3d)<smiles>O=C(OCC(C#Cc1ccccc1)N(Cc1ccccc1)C(=O)c1ccccc1)c1ccccc1I</smiles>

Performed on $0.2 \mathrm{mmol}$ scale. Obtained from tert-butyl benzyl(vinyl)carbamate (1d, $0.056 \mathrm{~g}, 0.24$ mmol, 1.2 equiv); $\operatorname{PhEBX}(\mathbf{2}, 0.070 \mathrm{~g}, 0.2 \mathrm{mmol}, 1.0$ equiv); $\operatorname{BIOAc}(\mathbf{7}$, $0.031 \mathrm{~g}, 0.1 \mathrm{mmol}, 0.5$ equiv) and 4-CICzIPN (4b, 4 mg, $4 \mu \mathrm{mol}, 2$ mol\%) after 18 hours.

Column: Pentane:EtOAc, 10:0 to 9:1. Yield $73 \%$ (0.085 g, 0.146 mmol). Pale yellow oil.

Rf (Pent.:EtOAc 9:1) $=0.25$.

${ }^{1} \mathbf{H}$ NMR $\left(400 \mathrm{MHz}\right.$, Acetonitrile- $d_{3}, 6: 4$ mixture of rotamers) $\delta 8.06(\mathrm{dd}, J=8.0,1.2 \mathrm{~Hz}, 1 \mathrm{H}, \mathrm{ArH}), 7.83$ $(\mathrm{dd}, J=7.8,1.7 \mathrm{~Hz}, 1 \mathrm{H}, \mathrm{ArH}), 7.49(\mathrm{t}, J=7.6 \mathrm{~Hz}, 1 \mathrm{H}, \mathrm{ArH}), 7.45-7.21(\mathrm{~m}, 11 \mathrm{H}, \mathrm{ArH}+\mathrm{PhH}), 5.78(\mathrm{~m}$, $0.6 \mathrm{H}$, major, $\mathrm{NCH}), 5.45(\mathrm{~m}, 0.4 \mathrm{H}$, minor, $\mathrm{NCH}), 4.71\left(\mathrm{~d}, J=16.3 \mathrm{~Hz}, 1 \mathrm{H}, \mathrm{PhCH}_{2}\right), 4.60(\mathrm{~d}, J=16.3 \mathrm{~Hz}$, $\left.1 \mathrm{H}, \mathrm{PhCH}_{2}\right), 4.52\left(\mathrm{dd}, J=11.2,5.5 \mathrm{~Hz}, 1 \mathrm{H}, \mathrm{OCH}_{2}\right), 4.46(\mathrm{dd}, J=11.2,8.4 \mathrm{~Hz}, 1 \mathrm{H}, \mathrm{OCH})_{2}, 1.62-1.16(\mathrm{~m}$, $\left.9 \mathrm{H}, \mathrm{C}\left(\mathrm{CH}_{3}\right)_{3}\right) .{ }^{13} \mathrm{C}$ NMR $\left(101 \mathrm{MHz}\right.$, Acetonitrile- $d_{3}$, mixture of rotamers, signals not fully resolved) $\delta$ 166.1, 155.7, 141.9, 140.4, 135.1, 133.7, 132.1, 131.6, 129.4, 129.1, 128.9, 128.8, 128.7, 127.5, 127.3, 122.5, 94.1, 86.6, 84.4, 81.0, 65.2, 48.2, 48.1, 28.0. IR $\left(\mathrm{v}_{\left.\max , \mathrm{Cm}^{-1}\right)} 3062(\mathrm{w}), 3029(\mathrm{w}), 2976(\mathrm{~m}), 2930(\mathrm{w})\right.$, 
$1733(\mathrm{~m}), 1704(\mathrm{~s}), 1685(\mathrm{~s}), 1392(\mathrm{~s}), 1366(\mathrm{~m}), 1287(\mathrm{~m}), 1242(\mathrm{~s}), 1162(\mathrm{~s}), 1131(\mathrm{~m}), 1119(\mathrm{~s}), 1101$ (s), 1016 (m). HRMS (ESI/QTOF) m/z: [M + Na] ${ }^{+}$Calcd for $\mathrm{C}_{29} \mathrm{H}_{28} \mathrm{INNaO}{ }_{4}{ }^{+}$604.0955; Found 604.0957.

2-(Methyl(tert-butoxycarbonyl)amino)-4-phenylbut-3-yn-1-yl 2-iodobenzoate (3e)

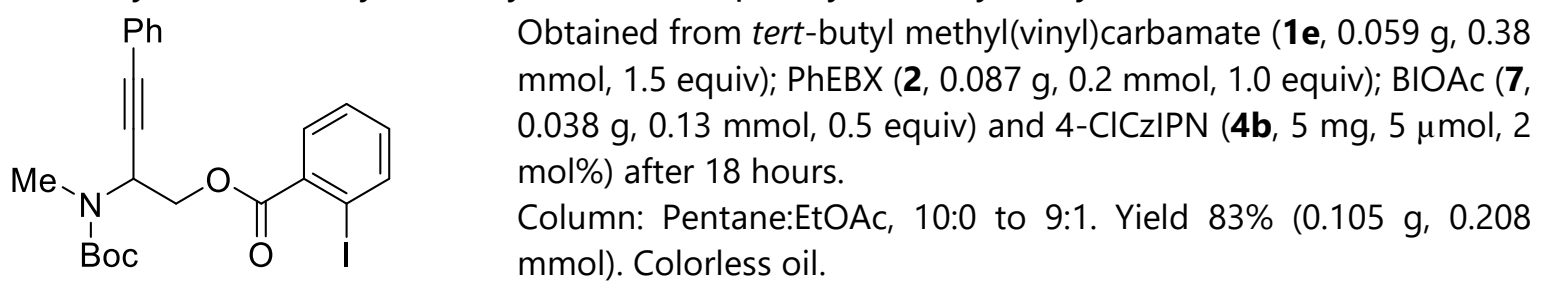

Rf (Pent.:EtOAc 9:1) $=0.25$.

${ }^{1} \mathbf{H}$ NMR $\left(400 \mathrm{MHz}\right.$, Acetonitrile- $d_{3,7} 7: 3$ mixture of rotamers) $\delta 8.06(\mathrm{~d}, J=7.9 \mathrm{~Hz}, 1 \mathrm{H}, \mathrm{ArH}), 7.83(\mathrm{~d}, J$ $=8.1 \mathrm{~Hz}, 1 \mathrm{H}, \mathrm{ArH}), 7.54-7.42(\mathrm{~m}, 3 \mathrm{H}, \mathrm{ArH}+\mathrm{PhH}), 7.46-7.35(\mathrm{~m}, 3 \mathrm{H}, \mathrm{PhH}), 7.26(\mathrm{td}, J=7.7,1.7 \mathrm{~Hz}$, $1 \mathrm{H}, \mathrm{ArH}), 5.70$ (bs, 0.7H, major, $\mathrm{NCH}), 5.54$ (bs, 0.3H, minor, $\mathrm{NCH}), 4.64-4.44(\mathrm{~m}, 2 \mathrm{H}, \mathrm{OCH}), 2.98(\mathrm{~s}$, $\left.3 \mathrm{H}, \mathrm{NCH}_{3}\right), 1.40\left(\mathrm{bs}, J=9.8 \mathrm{~Hz}, 9 \mathrm{H}, \mathrm{C}\left(\mathrm{CH}_{3}\right)_{3}\right) .{ }^{13} \mathrm{C} \mathrm{NMR}\left(101 \mathrm{MHz}\right.$, Acetonitrile- $d_{3}$, mixture of rotamers, signals not fully resolved) $\delta 166.6,156.3,155.3,142.3,135.7,134.1,132.6,132.0,129.9,129.6,129.2$, 122.9, 94.5, 94.4, 86.7, 84.1, 80.9, 64.4, 49.1, 47.9, 30.2, 28.4. IR $\left(\mathrm{V}_{\max } \mathrm{cm}^{-1}\right) 3059(\mathrm{w}), 2976(\mathrm{~m}), 2932$ (w), $2875(\mathrm{w}), 1733(\mathrm{~m}), 1685$ (s), $1388(\mathrm{~s}), 1245$ (s), 1147 (s), 741 (s). HRMS (ESI/QTOF) m/z: [M + $\mathrm{Na}]^{+}$Calcd for $\mathrm{C}_{23} \mathrm{H}_{24} \mathrm{INNaO}_{4}{ }^{+}$528.0642; Found 528.0651.

2-(Allyl(tert-butoxycarbonyl)amino)-4-phenylbut-3-yn-1-yl 2-iodobenzoate (3f)<smiles>C=CCN(C(=O)OCc1ccccc1)C(C#Cc1ccccc1)COC(=O)c1ccccc1I</smiles>
Obtained from tert-butyl allyyl(vinyl)carbamate $(\mathbf{1} f, 0.069 \mathrm{~g}, 0.38$ mmol, 1.5 equiv); $\operatorname{PhEBX}(\mathbf{2}, 0.087 \mathrm{~g}, 0.25 \mathrm{mmol}, 1.0$ equiv); BIOAc $(\mathbf{7}, 0.038 \mathrm{~g}, 0.13 \mathrm{mmol}, 0.5$ equiv) and $4-\mathrm{ClCzIPN}(\mathbf{4 b}, 5 \mathrm{mg}, 5 \mu \mathrm{mol}$, 2 mol\%) after 18 hours.

Column: Pentane:EtOAc, 10:0 to 9:1. Yield 54\% (0.072 g, $0.14 \mathrm{mmol})$. Pale yellow oil.

Rf $\left(\right.$ Pent.:Et ${ }_{2} \mathrm{O}$ 9:1) $=0.2$.

${ }^{1} \mathbf{H}$ NMR $\left(400 \mathrm{MHz}\right.$, Acetonitrile- $d_{3}, 6: 4$ mixture of rotamers) $\delta 8.04(\mathrm{dd}, J=8.0,1.2 \mathrm{~Hz}, 1 \mathrm{H}, \mathrm{ArH}), 7.83$ $(\mathrm{dd}, J=7.8,1.7 \mathrm{~Hz}, 1 \mathrm{H}, \mathrm{ArH}), 7.52-7.43(\mathrm{~m}, 3 \mathrm{H}, \mathrm{ArH}+\mathrm{PhH}), 7.43-7.33(\mathrm{~m}, 3 \mathrm{H}, \mathrm{PhH}), 7.24(\mathrm{td}, J=$ 7.7, $1.7 \mathrm{~Hz}, 1 \mathrm{H}, \mathrm{ArH}), 6.08-5.90\left(\mathrm{~m}, 1 \mathrm{H}, \mathrm{R}-\mathrm{CH}=\mathrm{CH}_{2}\right), 5.63(\mathrm{bs}, 0.6 \mathrm{H}, \mathrm{NCH}), 5.33(\mathrm{bs}, 0.4 \mathrm{H}, \mathrm{NCH}), 5.28-$ $5.19\left(\mathrm{~m}, 1 \mathrm{H}, \mathrm{CH}=\mathrm{CH}_{2}\right), 5.19-5.06\left(\mathrm{~m}, 1 \mathrm{H}, \mathrm{CH}=\mathrm{CH}_{2}\right), 4.49\left(\mathrm{~m}, 2 \mathrm{H}, \mathrm{CH}_{2}\right), 4.09-3.89\left(\mathrm{~m}, 2 \mathrm{H}, \mathrm{CH}_{2}\right), 1.39$ $\left(\mathrm{s}, 9 \mathrm{H}, \mathrm{C}\left(\mathrm{CH}_{3}\right)_{3}\right) .{ }^{13} \mathrm{C}$ NMR $(101 \mathrm{MHz}$, Acetonitrile-d3) $\delta$ 166.2, 155.6, 141.9, 136.3, 136.0, 135.3, 134.2, 133.7, 132.1, 131.6, 130.4, 129.5, 129.2, 128.8, 128.4, 122.6, 116.2, 114.8, 94.0, 80.8, 65.0, 28.2, 28.0. IR $\left(v_{\max }, \mathrm{cm}^{-1}\right) 3377(\mathrm{w}), 3073(\mathrm{w}), 2977(\mathrm{w}), 2933(\mathrm{w}), 1733(\mathrm{~m}), 1691(\mathrm{~s}), 1583(\mathrm{w}), 1449(\mathrm{~m}), 1395(\mathrm{~s})$, $1368(\mathrm{~m}), 1322(\mathrm{~m}), 1284(\mathrm{~m}), 1247(\mathrm{~s}), 1168(\mathrm{~s}), 1139(\mathrm{~s}), 1103(\mathrm{~m}), 1043(\mathrm{w}), 1014(\mathrm{~m}), 989(\mathrm{~m}), 920$ (w), $862(\mathrm{w}), 743(\mathrm{~s}), 692(\mathrm{~m})$. HRMS (ESI/QTOF) m/z: [M + Na] ${ }^{+}$Calcd for $\mathrm{C}_{25} \mathrm{H}_{26} \mathrm{INNaO}_{4}{ }^{+}$554.0799; Found 554.0809 .

2-((Tert-butoxycarbonyl)(2-((tert-butyldimethylsilyl)oxy)ethyl)amino)-4-phenylbut-3yn-1-yl 2-iodobenzoate $(\mathbf{3 g})$<smiles>CC(C)(C)OCCN(C(=O)OCC(C#Cc1ccccc1)(C(=O)O)C(=O)O)C(=O)c1ccccc1I</smiles>

Obtained from tert-butyl (2-((tertbutyldimethylsilyl)oxy)ethyl)(vinyl)carbamate (19,0.072 g, 0.24 mmol, 1.2 equiv); PhEBX (2, $0.070 \mathrm{~g}, 0.2 \mathrm{mmol}, 1.0$ equiv); BIOAc $(\mathbf{7}, 0.031 \mathrm{~g}, 0.1 \mathrm{mmol}, 0.5$ equiv) and $4-\mathrm{ClCZIPN}(\mathbf{4 b}, 4 \mathrm{mg}, 4$ $\mu \mathrm{mol}, 2 \mathrm{~mol} \%)$ after 18 hours.

Column: Pentane:EtOAc, 10:0 to 9:1. Yield 52\% (0.068 g, 0.11 mmol). Pale yellow oil. 
Rf (Pent.:EtOAc 9:1) $=0.4$.

${ }^{1} \mathbf{H}$ NMR $\left(400 \mathrm{MHz}\right.$, Acetonitrile- $d_{3,}, 7: 3$ mixture of rotamers) $\delta 8.05-7.98(\mathrm{~m}, 1 \mathrm{H}, \mathrm{Ar} H), 7.80(\mathrm{dd}, J=$ 7.8, 1.7 Hz, 1H, ArH), $7.48-7.38(\mathrm{~m}, 3 \mathrm{H}, \mathrm{ArH}+\mathrm{PhH}), 7.41-7.29(\mathrm{~m}, 3 \mathrm{H}, \mathrm{PhH}), 7.21(\mathrm{td}, J=7.7,1.8 \mathrm{~Hz}$, $1 \mathrm{H}, \mathrm{ArH}), 5.53(\mathrm{bs}, 0.6 \mathrm{H}$, major, $\mathrm{NCH}), 5.24(\mathrm{~s}, 0.4 \mathrm{H}$, minor, $\mathrm{NCH}), 4.65-4.35\left(\mathrm{~m}, 2 \mathrm{H}, \mathrm{CH}_{2}\right), 3.82-3.74$ $\left(\mathrm{m}, 2 \mathrm{H}, \mathrm{CH}_{2}\right), 3.44\left(\mathrm{~d}, J=6.9 \mathrm{~Hz}, 2 \mathrm{H}, \mathrm{CH}_{2}\right), 1.38\left(\mathrm{~s}, 9 \mathrm{H}, \mathrm{C}\left(\mathrm{CH}_{3}\right)_{3}\right), 0.83\left(\mathrm{~s}, 9 \mathrm{H}, \mathrm{C}\left(\mathrm{CH}_{3}\right)_{3}\right), 0.00\left(\mathrm{~s}, 6 \mathrm{H}, \mathrm{Me}_{2}\right)$. ${ }^{13} \mathrm{C}$ NMR $\left(101 \mathrm{MHz}\right.$, Acetonitrile- $d_{3}$, mixture of rotamers, signals not fully resolved) $\delta 166.7,142.3$, $135.9,134.1,132.6,132.0,129.9,129.6,129.2,94.4,81.3,65.7,62.5,48.7,48.3,47.5,28.5,26.3,26.3$,

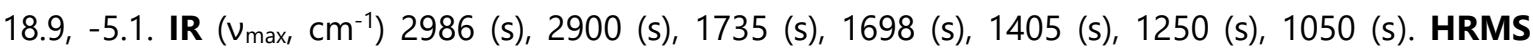
(ESI/QTOF) m/z: $[\mathrm{M}+\mathrm{H}]^{+}$Calcd for $\mathrm{C}_{30} \mathrm{H}_{41} \mathrm{INO}_{5} \mathrm{Si}^{+}$650.1793; Found 650.1791.

2-((Tert-butoxycarbonyl)(3-ethoxy-3-oxopropyl)amino)-4-phenylbut-3-yn-1-yl iodobenzoate (3h)<smiles>CCOC(=O)c1ccccc1</smiles>
Obtained from ethyl 3-((tertbutoxycarbonyl)(vinyl)amino)propanoate $(\mathbf{1 h}, 0.058 \mathrm{~g}, 0.24$ mmol, 1.2 equiv); $\operatorname{PhEBX}(\mathbf{2}, 0.070 \mathrm{~g}, 0.2 \mathrm{mmol}, 1.0$ equiv); BIOAc (7, $0.031 \mathrm{~g}, 0.1 \mathrm{mmol}, 0.5$ equiv) and 4-CICzIPN (4b, 4 mg, 4 $\mu \mathrm{mol}, 2 \mathrm{~mol} \%)$ after 18 hours.

Column: Pentane:EtOAc, 10:0 to 9:1. Yield $69 \%(0.082 \mathrm{~g}, 0.14$ $\mathrm{mmol})$. Pale yellow oil.

Rf (Pent.:EtOAc 9:1) $=0.35$.

${ }^{1} \mathbf{H}$ NMR $\left(400 \mathrm{MHz}\right.$, Acetonitrile- $d_{3}, 7: 3$ mixture of rotamers) $\delta 8.05-7.98(\mathrm{~m}, 1 \mathrm{H}, \mathrm{Ar} H), 7.80(\mathrm{~d}, J=$ $7.8 \mathrm{~Hz}, 1 \mathrm{H}, \mathrm{ArH}), 7.48-7.41(\mathrm{~m}, 3 \mathrm{H}, \mathrm{ArH}$ and $\mathrm{PhH}), 7.41-7.30(\mathrm{~m}, 3 \mathrm{H}, \mathrm{ArH}$ and $\mathrm{PhH}), 7.22(\mathrm{td}, J=7.7$, $1.7 \mathrm{~Hz}, 1 \mathrm{H}, \mathrm{ArH}), 5.53(\mathrm{bs}, 0.7 \mathrm{H}$, major, $\mathrm{NCH}), 5.31$ (bs, $0.3 \mathrm{H}$, minor, $\mathrm{NCH}), 4.50\left(\mathrm{~d}, J=7.0 \mathrm{~Hz}, 2 \mathrm{H}, \mathrm{OCH}_{2^{-}}\right.$ $\mathrm{CHN}), 4.02\left(\mathrm{q}, J=7.1 \mathrm{~Hz}, 2 \mathrm{H}, \mathrm{OCH}_{2} \mathrm{CH}_{3}\right), 3.60\left(\mathrm{~m}, 2 \mathrm{H}, \mathrm{CH}_{2}\right), 2.68\left(\mathrm{~d}, J=8.7 \mathrm{~Hz}, 2 \mathrm{H}, \mathrm{CH}_{2}\right), 1.37(\mathrm{~s}, 9 \mathrm{H}$, $\left.\mathrm{C}\left(\mathrm{CH}_{3}\right)_{3}\right), 1.13\left(\mathrm{t}, J=7.1 \mathrm{~Hz}, 3 \mathrm{H}, \mathrm{OCH}_{2} \mathrm{CH}_{3}\right) .{ }^{13} \mathrm{C}$ NMR $\left(101 \mathrm{MHz}\right.$, Acetonitrile- $d_{3}$, mixture of rotamers, signals not fully resolved) $\delta 172.0,166.2,142.0,135.3,133.7,132.2,131.6,129.6,129.2,128.8,122.5$, 94.0, 81.1, 65.0, 60.8, 47.6, 35.1, 28.0, 14.1. IR $\left(v_{\max ,} \mathrm{cm}^{-1}\right) 3009(\mathrm{~s}), 3004(\mathrm{~s}), 2974(\mathrm{~s}), 2943(\mathrm{~s}), 2928(\mathrm{~s})$, $2883(\mathrm{~s}), 1739(\mathrm{~s}), 1726(\mathrm{~s}), 1716(\mathrm{~s}), 1705(\mathrm{~s}), 1696(\mathrm{~s}), 1685(\mathrm{~s}), 1678(\mathrm{~s}), 1406$ (s), $1248(\mathrm{~s}), 1159$ (s), 1046 (s). HRMS (ESI/QTOF) m/z: $[\mathrm{M}+\mathrm{Na}]^{+}$Calcd for $\mathrm{C}_{27} \mathrm{H}_{30} \mathrm{INNaO}_{6}{ }^{+}$614.1010; Found 614.1011.

2-((Tert-butoxycarbonyl)(cyclohexyl)amino)-4-phenylbut-3-yn-1-yl 2-iodobenzoate (3i)<smiles>O=C(OCC(C#Cc1ccccc1)N(C(=O)OCc1ccccc1)C1CCCCC1)c1ccccc1I</smiles>
Obtained from cyclohexyl(vinyl)carbamate $(\mathbf{1 i}, 0.068 \mathrm{~g}, 0.24 \mathrm{mmol}$, 1.2 equiv); $\operatorname{PhEBX}(\mathbf{2}, 0.070 \mathrm{~g}, 0.2 \mathrm{mmol}, 1.0$ equiv); $\operatorname{BIOAc}(\mathbf{7}, 0.031 \mathrm{~g}$, $0.1 \mathrm{mmol}, 0.5$ equiv) and 4 -CICzIPN (4b, $4 \mathrm{mg}, 4 \mu \mathrm{mol}, 2 \mathrm{~mol} \%)$ after 18 hours.

Column: Pentane:EtOAc, 10:0 to 9:1. Yield 65\% (0.074 g, $0.13 \mathrm{mmol})$. Pale yellow oil.

Rf (Pent.:EtOAc 9:1) $=0.3$.

${ }^{1} \mathbf{H}$ NMR $\left(400 \mathrm{MHz}\right.$, Acetonitrile- $d_{3}, 1: 1$ mixture of rotamers) $\delta 8.04$ (dd, $\left.J=7.9,1.2 \mathrm{~Hz}, 1 \mathrm{H}, \mathrm{ArH}\right), 7.82$ $(\mathrm{dd}, J=7.8,1.7 \mathrm{~Hz}, 1 \mathrm{H}, \mathrm{ArH}), 7.50-7.41(\mathrm{~m}, 3 \mathrm{H}, \mathrm{ArH}$ and $\mathrm{PhH}), 7.41-7.32(\mathrm{~m}, 3 \mathrm{H}, \mathrm{ArH}$ and $\mathrm{PhH}), 7.24$ (td, $J=7.7,1.7 \mathrm{~Hz}, 1 \mathrm{H}, \mathrm{ArH}), 5.49$ (bs, $0.5 \mathrm{H}, \mathrm{N}-\mathrm{CH}$-alkyne), 5.01 (bs, $0.5 \mathrm{H}, \mathrm{NCH}$-alkyne), 4.59 (bs, $1 \mathrm{H}$, $\left.\mathrm{OCH}_{2}\right), 4.50\left(\mathrm{bs}, 1 \mathrm{H}, \mathrm{OCH}_{2}\right) 3.70$ (bs, 0.5H, CyH-N), 3.44 (bs, 0.5H, CyH-N), $1.88-1.69(\mathrm{~m}, 4 \mathrm{H}, \mathrm{Cy}), 1.70$ - $1.53(\mathrm{~m}, 2 \mathrm{H}, \mathrm{Cy}), 1.44\left(\mathrm{~s}, 9 \mathrm{H}, \mathrm{C}\left(\mathrm{CH}_{3}\right)_{3}\right), 1.37-1.22(\mathrm{~m}, 2 \mathrm{H}, \mathrm{Cy}), 1.12(\mathrm{ddt}, J=16.3,12.7,3.4 \mathrm{~Hz}, 2 \mathrm{H}$, Cy). ${ }^{13} \mathrm{C}$ NMR (101 MHz, Acetonitrile- $d_{3}$, mixture of rotamers, signals not fully resolved) $\delta 166.4,141.9$, 135.5, 133.7, 132.0, 131.5, 129.3, 129.2, 128.8, 122.9, 94.0, 80.6, 65.7, 65.4, 56.6, 33.6, 31.5, 28.2, 26.6, 25.9, 25.4. IR ( $\left.v_{\text {max }} \mathrm{cm}^{-1}\right) 2987$ (s), 2972 (s), 2960 (s), 2901 (s), 1733 (s), 1705 (s), 1698 (s), 1686 (s). HRMS (ESI/QTOF) m/z: [M + Na] ${ }^{+}$Calcd for $\mathrm{C}_{28} \mathrm{H}_{32} \mathrm{INNaO}_{4}{ }^{+}$596.1268; Found 596.1270. 
2-(2-oxopyrrolidin-1-yl)-4-phenylbut-3-yn-1-yl 2-iodobenzoate (3j)<smiles>O=C(OCC(C#Cc1ccccc1)N1CCCC1=O)c1ccccc1I</smiles>

Obtained from $N$-vinyl pyrrolidinone $(\mathbf{1} \mathbf{j}, 0.042 \mathrm{~g}, 0.38 \mathrm{mmol}, 1.5$ equiv); $\operatorname{PhEBX}(\mathbf{2}, 0.087 \mathrm{~g}, 0.25 \mathrm{mmol}, 1.0$ equiv); $\operatorname{BIOAc}(\mathbf{7}, 0.031 \mathrm{~g}$, $0.1 \mathrm{mmol}, 0.5$ equiv) and $4-\mathrm{ClCzIPN}(\mathbf{4 b}, 4 \mathrm{mg}, 4 \mu \mathrm{mol}, 2 \mathrm{~mol} \%)$ after 18 hours.

Column: Pentane:EtOAc, 9:1 to 8:2. Yield $85 \%(0.098 \mathrm{~g}, 0.21 \mathrm{mmol})$. Pale yellow oil.

Rf (Pent:.EtOAc 9:1) $=0.25$.

${ }^{1} \mathbf{H}$ NMR $\left(400 \mathrm{MHz}\right.$, Acetonitrile- $\left.d_{3}\right) \delta 8.06(\mathrm{dd}, J=7.9,1.2 \mathrm{~Hz}, 1 \mathrm{H}, \mathrm{ArH}), 7.81(\mathrm{dd}, J=7.8,1.7 \mathrm{~Hz}, 1 \mathrm{H}$, $\mathrm{ArH}), 7.58-7.47(\mathrm{~m}, 3 \mathrm{H}, \mathrm{ArH}$ and $\mathrm{PhH}), 7.47-7.33(\mathrm{~m}, 3 \mathrm{H}, \mathrm{PhH}), 7.27(\mathrm{td}, J=7.7,1.8 \mathrm{~Hz}, 1 \mathrm{H}, \mathrm{ArH})$, $5.53\left(\mathrm{dd}, J=8.6,4.8 \mathrm{~Hz}, 1 \mathrm{H}, \mathrm{NCHCH} \mathrm{O}_{2} \mathrm{O}\right), 4.64\left(\mathrm{dd}, J=11.3,8.6 \mathrm{~Hz}, 1 \mathrm{H}, \mathrm{NCHCH}_{2} \mathrm{O}\right), 4.50(\mathrm{dd}, J=11.2$, $\left.4.8 \mathrm{~Hz}, 1 \mathrm{H}, \mathrm{NCHCH}_{2} \mathrm{O}\right), 3.75-3.52\left(\mathrm{~m}, 2 \mathrm{H}, \mathrm{CH}_{2}\right), 2.39-2.30\left(\mathrm{~m}, 2 \mathrm{H}, \mathrm{CH}_{2}\right), 2.12-2.02\left(\mathrm{~m}, 2 \mathrm{H}, \mathrm{CH}_{2}\right) .{ }^{13} \mathrm{C}$ NMR $\left(101 \mathrm{MHz}\right.$, Acetonitrile- $\left.d_{3}\right) \delta 175.4,166.5,141.8,135.6,133.7,132.3,131.4,129.6,129.2,129.1$, 128.9, 122.4, 93.8, 86.0, 83.1, 64.4, 43.9, 31.1, 18.2. IR $\left(\nu_{\left.\max , \mathrm{cm}^{-1}\right)} 3054(\mathrm{~s}), 2972(\mathrm{~s}), 2894(\mathrm{~s}), 1732(\mathrm{~s})\right.$, 1686 (s), 1417 (s), 1284 (s), 1246 (s), 1132 (s), 1104 (s). HRMS (ESI/QTOF) m/z: [M + H] ${ }^{+}$Calcd for $\mathrm{C}_{21} \mathrm{H}_{19} \mathrm{INO}_{3}{ }^{+}$460.0404; Found 460.0414

3-(2-Oxooxazolidin-3-yl)-1-phenyloct-1-yn-4-yl 2-iodobenzoate (3I)<smiles>CCCCC#CC(C(C#Cc1ccccc1)CCCCCC)N1CCOC1=O</smiles>
Obtained from (E)-3-(Hex-1-en-1-yl)oxazolidin-2-one ((E)-11, 0.064 g, $0.38 \mathrm{mmol}, 1.5$ equiv); $\operatorname{PhEBX}(\mathbf{2}, 0.087 \mathrm{~g}, 0.25 \mathrm{mmol}, 1.0$ equiv); $\operatorname{BIOAC}(\mathbf{7}, 0.038 \mathrm{~g}, 0.13 \mathrm{mmol}, 0.5$ equiv) and 4-CICzIPN (4b, $5 \mathrm{mg}$, $5 \mu \mathrm{mol}, 2 \mathrm{~mol} \%)$ after 18 hours.

Column: Pentane:EtOAc, 19:1 to 8:2. Isolated separately as two diastereoisomers $(0.076 \mathrm{~g}, 60 \%$ and $0.027 \mathrm{~g}, 20 \%$ yield) as 2 colorless oils. Overall yield $80 \%(0.103 \mathrm{~g}, 0.199 \mathrm{mmol}$, dr: $3: 1)$.

Obtained from 2:1 mixture of (Z)-3-(Hex-1-en-1-yl)oxazolidin-2-one and ( $E$-isomer ((Z:E)-1 k, 0.064 g, $0.38 \mathrm{mmol}, 1.5$ equiv); PhEBX (2, $0.087 \mathrm{~g}, 0.25 \mathrm{mmol}, 1.0$ equiv);

$\operatorname{BIOAC}(\mathbf{7}, 0.038 \mathrm{~g}, 0.13 \mathrm{mmol}, 0.5$ equiv) and 4-CICZIPN (4b, $5 \mathrm{mg}, 5$ mol, 2 mol\%) after 18 hours. Column: Pentane:EtOAc, $19: 1$ to 8:2. Isolated seperately as two diastereoisomers $(0.079 \mathrm{~g}, 61 \%$ yield and $0.025 \mathrm{~g}, 19 \%$ yield) as 2 colorless oils.. Overall yield $80 \%(0.104 \mathrm{~g}, 0.201 \mathrm{mmol}$, dr: 3:1).

Major diastereoisomer:

Rf (Pent:EtOAc 7:3) $=0.4$.

${ }^{1}$ H NMR $(400 \mathrm{MHz}$, Chloroform- $d) \delta 7.99(\mathrm{dd}, J=8.0,1.2 \mathrm{~Hz}, 1 \mathrm{H}, \mathrm{ArH}), 7.78(\mathrm{dd}, J=7.8,1.7 \mathrm{~Hz}, 1 \mathrm{H}$, $\operatorname{ArH}), 7.45-7.42(\mathrm{~m}, 2 \mathrm{H}, \mathrm{PhH}), 7.40(\mathrm{dd}, J=7.6,1.3 \mathrm{~Hz}, 1 \mathrm{H}, \mathrm{ArH}), 7.38-7.30(\mathrm{~m}, 3 \mathrm{H}, \mathrm{PhH}), 7.16(\mathrm{td}, J$ $=7.7,1.7 \mathrm{~Hz}, 1 \mathrm{H}, \mathrm{ArH}), 5.43(\mathrm{td}, J=8.7,3.4 \mathrm{~Hz}, 1 \mathrm{H}, \mathrm{OCH}), 5.11(\mathrm{~d}, J=8.5 \mathrm{~Hz}, 1 \mathrm{H}, \mathrm{NCH}), 4.37(\mathrm{td}, J=$ $\left.8.1,6.0 \mathrm{~Hz}, 1 \mathrm{H}, \mathrm{CH}_{2}\right), 4.30\left(\mathrm{q}, J=8.8 \mathrm{~Hz}, 1 \mathrm{H}, \mathrm{CH}_{2}\right), 3.86-3.76\left(\mathrm{~m}, 2 \mathrm{H}, \mathrm{CH}_{2}\right), 2.02\left(\mathrm{~m}, 1 \mathrm{H}, \mathrm{CH}_{2}\right), 1.86$ (dtd, $\left.J=14.4,8.8,5.8 \mathrm{~Hz}, 1 \mathrm{H}, \mathrm{CH}_{2}\right), 1.59-1.27\left(\mathrm{~m}, 4 \mathrm{H} \mathrm{CH}-\mathrm{CH}_{2}-\mathrm{CH}_{3}\right), 0.92\left(\mathrm{t}, J=7.2 \mathrm{~Hz}, 3 \mathrm{H}, \mathrm{CH}_{3}\right) .{ }^{13} \mathbf{C} \mathbf{~ N M R}$ $(101 \mathrm{MHz}$, Chloroform-d) $\delta 166.3,158.3,141.3,134.8,132.9,131.9,130.9,129.1,128.5,128.2,121.6$, 94.1, 87.8, 81.6, 73.8, 62.5, 50.5, 41.6, 31.1, 27.2, 22.4, 13.9. IR $\left(v_{\max ,} \mathrm{cm}^{-1}\right) 2960(\mathrm{w}), 2929(\mathrm{w}), 2862(\mathrm{w})$, $2252(\mathrm{w}), 1742(\mathrm{~m}), 1736(\mathrm{~m}), 1420(\mathrm{~m}), 1286(\mathrm{~m}), 1249(\mathrm{~m}), 907$ (s), 727 (s). HRMS (ESI/QTOF) m/z: $[\mathrm{M}+\mathrm{Na}]^{+}$Calcd for $\mathrm{C}_{24} \mathrm{H}_{24} \mathrm{INNaO}_{4}{ }^{+} 540.0642$; Found 540.0640 .

Minor diastereoisomer:

Rf (Pent:EtOAc 7:3) $=0.35$.

${ }^{1}$ H NMR $(400 \mathrm{MHz}$, Chloroform- $d) \delta 7.99(\mathrm{dd}, J=8.0,1.2 \mathrm{~Hz}, 1 \mathrm{H}, \mathrm{ArH}), 7.78(\mathrm{dd}, J=7.8,1.7 \mathrm{~Hz}, 1 \mathrm{H}$, $\mathrm{ArH}), 7.50-7.30(\mathrm{~m}, 6 \mathrm{H}, \mathrm{PhH}+\mathrm{ArH}), 7.16(\mathrm{td}, J=7.7,1.7 \mathrm{~Hz}, 1 \mathrm{H}, \mathrm{ArH}), 5.43(\mathrm{td}, J=8.7,3.4 \mathrm{~Hz}, 1 \mathrm{H}$ $\mathrm{OCH}), 5.11(\mathrm{~d}, J=8.5 \mathrm{~Hz}, 1 \mathrm{H}, \mathrm{NCH}), 4.52-4.24\left(\mathrm{~m}, 2 \mathrm{H}, \mathrm{CH}_{2}\right), 3.91-3.77\left(\mathrm{~m}, 2 \mathrm{H}, \mathrm{CH}_{2}\right), 2.05(\mathrm{~m}, 1 \mathrm{H}$, $\left.\mathrm{CH}_{2}\right), 1.86\left(\mathrm{~m}, 5.7 \mathrm{~Hz}, 1 \mathrm{H}, \mathrm{CH}_{2}\right), 1.56-1.21\left(\mathrm{~m}, 4 \mathrm{H}, \mathrm{CH}_{2}-\mathrm{CH}_{2}-\mathrm{CH}_{3}\right), 0.90\left(\mathrm{dt}, J=18.0,7.2 \mathrm{~Hz}, 3 \mathrm{H}, \mathrm{CH}_{2}-\right.$ $\left.\mathrm{CH}_{2}-\mathrm{CH}_{3}\right) .{ }^{13} \mathrm{C}$ NMR $(101 \mathrm{MHz}$, Chloroform-d) $\delta$ 165.7, 158.2, 141.7, 134.7, 133.1, 132.0, 131.3, 129.1, $128.5,128.2,122.0,94.5,87.7,81.7,75.8,62.6,50.2,42.7,31.3,27.5,22.6,14.1$. IR $\left(\nu_{\max } \mathrm{cm}^{-1}\right) 2957(\mathrm{~m})$, 
$2925(\mathrm{~m}), 2871(\mathrm{~m}), 1743(\mathrm{~s}), 1727(\mathrm{~s}), 1490(\mathrm{~m}), 1417(\mathrm{~m}), 1246(\mathrm{~s}), 1133(\mathrm{~s}), 759(\mathrm{~s}), 741$ (s). HRMS (ESI/QTOF) m/z: [M + H] $]^{+}$Calcd for $\mathrm{C}_{24} \mathrm{H}_{25} \mathrm{INO}_{4}{ }^{+}$518.0823; Found 518.0830.

\section{2-Butoxy-4-phenylbut-3-yn-1-yl 2-iodobenzoate (10a)}<smiles>CCCCOC(C#Cc1ccccc1)COC(=O)c1ccccc1I</smiles>

Obtained from nbutyl vinyl ether $(\mathbf{9 a}, 0.048 \mathrm{~mL}, 0.38 \mathrm{mmol}, 1.5$ equiv); $\operatorname{PhEBX}(\mathbf{2}, 0.087 \mathrm{~g}, 0.25 \mathrm{mmol}, 1.0$ equiv); $\operatorname{BIOAc}(\mathbf{7}, 0.038 \mathrm{~g}$, $0.1 \mathrm{mmol}, 0.5$ equiv) and $4-\mathrm{ClCZIPN}(\mathbf{4 b}, 5 \mathrm{mg}, 5$ umol, 2 mol\%) after 18 hours.

Column: Pentane:Et $2 \mathrm{O}, 100: 0$ to $95: 5$. Yield $89 \%(0.100 \mathrm{~g}, 0.223$ $\mathrm{mmol})$. Colorless oil.

Rf (Pentane: $\mathrm{Et}_{2} \mathrm{O}$ 95:5) $=0.4$.

${ }^{1} \mathbf{H}$ NMR $(400 \mathrm{MHz}$, Chloroform- $d) \delta 8.00(\mathrm{dd}, J=7.9,1.3 \mathrm{~Hz}, 1 \mathrm{H}, \mathrm{ArH}), 7.88(\mathrm{dd}, J=7.8,1.7 \mathrm{~Hz}, 1 \mathrm{H}$, ArH), $7.48-7.41(\mathrm{~m}, 2 \mathrm{H}, \mathrm{PhH}), 7.39(\mathrm{t}, J=7.6 \mathrm{~Hz}, 1 \mathrm{H}, \mathrm{ArH}), 7.36-7.27(\mathrm{~m}, 3 \mathrm{H}, \mathrm{PhH}), 7.15(\mathrm{td}, J=7.7$, $1.8 \mathrm{~Hz}, 1 \mathrm{H}, \mathrm{ArH}), 4.68(\mathrm{dd}, J=6.8,4.8 \mathrm{~Hz}, 1 \mathrm{H}, \mathrm{OCHCH})_{2}, 4.57\left(\mathrm{~d}, J=5.2 \mathrm{~Hz}, 2 \mathrm{H}, \mathrm{CH}_{2}\right), 3.86(\mathrm{dt}, J=9.1$, $\left.6.6 \mathrm{~Hz}, 1 \mathrm{H}, \mathrm{CH}_{2}\right), 3.55\left(\mathrm{dt}, J=9.1,6.5 \mathrm{~Hz}, 1 \mathrm{H}, \mathrm{CH}_{2}\right), 1.63\left(\mathrm{dq}, J=8.3,6.6 \mathrm{~Hz}, 2 \mathrm{H}, \mathrm{CH}_{2}\right), 1.49-1.35(\mathrm{~m}$, $\left.2 \mathrm{H}, \mathrm{CH}_{2}\right), 0.92\left(\mathrm{t}, J=7.4 \mathrm{~Hz}, 3 \mathrm{H}, \mathrm{CH}_{3}\right) .{ }^{13} \mathrm{C}$ NMR $(101 \mathrm{MHz}$, Chloroform-d) $\delta 166.2,141.5,134.8,132.9$, 132.0, 131.4, 128.8, 128.4, 128.0, 122.4, 94.4, 87.1, 84.9, 69.2, 68.3, 66.8, 31.8, 19.4, 14.0. IR $\left(v_{\max } \mathrm{cm}^{-1}\right)$ $2987(\mathrm{~s}), 2978(\mathrm{~s}), 2934$ (s), $2912(\mathrm{~s}), 2901$ (s), 2855 (s), 1756 (s), 1465 (s), 1428 (s), 1378 (s), 1269 (s), 1103 (s), 1076 (s), 1057 (s), 1027 (s). HRMS (ESI/QTOF) m/z: [M + Na] Calcd for $\mathrm{C}_{21} \mathrm{H}_{21} \mathrm{INaO}_{3}{ }^{+}$471.0428; Found 471.0438 .

\section{2-Benzyloxy-4-phenylbut-1-yn-4-yl 2-iodobenzoate (10b)}<smiles>O=C(OCC(C#Cc1ccccc1)OCc1ccccc1)c1ccccc1I</smiles>
Obtained from ((vinyloxy)methyl)benzene $(\mathbf{9 b}, 50 \mu \mathrm{l}, 0.38 \mathrm{mmol}, 1.5$ equiv); $\operatorname{PhEBX}(\mathbf{2}, 0.087 \mathrm{~g}, 0.2 \mathrm{mmol}, 1.0$ equiv); $\operatorname{BIOAc}(\mathbf{7}, 0.038 \mathrm{~g}$, $0.1 \mathrm{mmol}, 0.5$ equiv) and 4-CICzIPN (4b, 4 mg, 4 mol, 2 mol\%) after 18 hours.

Column: Pentane:EtOAc, 9:1 to 8:2. Yield 58\% (70 mg, $0.15 \mathrm{mmol})$. Yellow oil.

Rf (Pent:EtOAc $=9: 1)=0.4$

${ }^{1} \mathbf{H}$ NMR $\left(400 \mathrm{MHz}\right.$, Acetonitrile- $\left.d_{3}\right) \delta 8.03(\mathrm{dd}, J=8.0,1.2 \mathrm{~Hz}, 1 \mathrm{H}, \mathrm{ArH}), 7.79(\mathrm{dd}, J=7.8,1.7 \mathrm{~Hz}, 1 \mathrm{H}$, $\mathrm{ArH}), 7.58-7.44(\mathrm{~m}, 3 \mathrm{H}, \mathrm{PhH}+\mathrm{ArH}), 7.45-7.26(\mathrm{~m}, 8 \mathrm{H}, \mathrm{PhH}), 7.24(\mathrm{td}, J=7.7,1.7 \mathrm{~Hz}, 1 \mathrm{H}, \mathrm{ArH}), 4.87$ $\left(\mathrm{d}, J=11.7 \mathrm{~Hz}, 1 \mathrm{H}, \mathrm{PhCH}_{2}\right), 4.77(\mathrm{dd}, J=6.6,4.2 \mathrm{~Hz}, 1 \mathrm{H}, \mathrm{OCH}), 4.66\left(\mathrm{~d}, J=11.7 \mathrm{~Hz}, 1 \mathrm{H}, \mathrm{PhCH}_{2}\right), 4.64-$ $4.50\left(\mathrm{~m}, 2 \mathrm{H}, \mathrm{OCH}_{2}\right) .{ }^{13} \mathrm{C}$ NMR $\left(101 \mathrm{MHz}\right.$, Acetonitrile- $\left.d_{3}\right) \delta 166.6,141.8,138.4,135.9,133.6,132.3$, $131.3,129.6,129.2,129.0,128.9,128.7,128.4,122.5,93.8,87.5,85.1,71.2,68.1,66.8 . \mathbf{I R}\left(v_{\left.\max , \mathrm{cm}^{-1}\right)}\right.$ 2987 (s), 2972 (s), 2959 (s), 2920 (s), 2909 (s), 2901 (s), 2884 (s), 1726 (s), 1394 (s), 1375 (s), 1286 (s), 1265 (s), 1243 (s), 1135 (s), 1076 (s), 1038 (s), 1016 (s). HRMS (APPI/LTQ-Orbitrap) m/z: [M + H] ${ }^{+}$Calcd for $\mathrm{C}_{24} \mathrm{H}_{20} \mathrm{OO}_{3}{ }^{+}$483.0452; Found 483.0435 .

\section{2-(Allyloxy)-4-phenylbut-3-yn-1-yl 2-iodobenzoate (10c)}<smiles>C=CCOC(C#CPc1ccccc1)COC(=O)c1ccccc1I</smiles>

Obtained from (allyloxy)ethene $(9 \mathbf{c}, 0.039 \mathrm{~mL}, 0.38 \mathrm{mmol}, 1.5$ equiv); PhEBX (2, $0.087 \mathrm{~g}, 0.25 \mathrm{mmol}, 1.0$ equiv); $\operatorname{BIOAc}(\mathbf{7}, 0.038 \mathrm{~g}$, $0.13 \mathrm{mmol}, 0.5$ equiv) and $4-\mathrm{ClCzIPN}(\mathbf{4 b}, 5 \mathrm{mg}, 5 \mu \mathrm{mol}, 2 \mathrm{~mol} \%)$ after 18 hours.

Column: Pentane:Et ${ }_{2} \mathrm{O}, 95: 5$ to $90: 10$. Some fractions were not pure and were purified by preparative TLC (Pentane:Et $2 \mathrm{O} 93: 7)$. Combined yield 46\% (0.050 g, $0.12 \mathrm{mmol})$. Colorless oil.

Rf (Pent:Et $2 \mathrm{O}=9: 1)=0.5$. 
${ }^{1} \mathbf{H}$ NMR $(400 \mathrm{MHz}$, Acetonitrile-d3) $\delta 8.03(\mathrm{dd}, J=7.9,1.1 \mathrm{~Hz}, 1 \mathrm{H}, \operatorname{ArH}), 7.82(\mathrm{~d}, J=1.7 \mathrm{~Hz}, 1 \mathrm{H}, \mathrm{ArH})$, $7.53-7.43(\mathrm{~m}, 3 \mathrm{H}, \mathrm{PhH}+\mathrm{ArH}), 7.42-7.32(\mathrm{~m}, 3 \mathrm{H}, \mathrm{PhH}), 7.25(\mathrm{ddd}, J=8.0,7.5,1.7 \mathrm{~Hz}, 1 \mathrm{H}, \mathrm{ArH}), 5.97$ (dddd, $\left.J=17.2,10.4,6.0,5.2 \mathrm{~Hz}, 1 \mathrm{H}, \mathrm{CH}=\mathrm{CH}_{2}\right), 5.35\left(\mathrm{dq}, J=17.3,1.7 \mathrm{~Hz}, 1 \mathrm{H}, \mathrm{CH}=\mathrm{CH}_{2}\right), 5.22-5.18(\mathrm{~m}$, $\left.1 \mathrm{H}, \mathrm{CH}=\mathrm{CH}_{2}\right), 4.75(\mathrm{dd}, J=6.3,4.4 \mathrm{~Hz}, 1 \mathrm{H}, \mathrm{OCH}), 4.62-4.47\left(\mathrm{~m}, 2 \mathrm{H}, \mathrm{OCH}_{2}\right), 4.33(\mathrm{ddt}, J=12.7,5.2,1.5$ $\left.\mathrm{Hz}, 1 \mathrm{H}, \mathrm{OCH}_{2}\right), 4.13\left(\mathrm{ddt}, J=12.7,6.0,1.4 \mathrm{~Hz}, 1 \mathrm{H}, \mathrm{OCH}_{2}\right) .{ }^{13} \mathrm{C}$ NMR $\left(101 \mathrm{MHz}\right.$, Acetonitrile- $\left.d_{3}\right) \delta 166.7$, 141.7, 136.0, 135.0, 133.6, 132.2, 131.2, 129.5, 129.2, 128.9, 122.5, 117.4, 93.7, 87.2, 85.2, 70.2, 68.0, 66.8. IR $\left(v_{\text {max }} \mathrm{cm}^{-1}\right) 3078(\mathrm{~m}), 2987(\mathrm{~s}), 2972(\mathrm{~s}), 2900(\mathrm{~s}), 1732(\mathrm{~s}), 1286(\mathrm{~s}), 1243(\mathrm{~s}), 1134(\mathrm{~s}), 1097(\mathrm{~s})$, 1079 (s), 1045 (s), 1016 (s). HRMS (APPI/LTQ-Orbitrap) m/z: [M] ${ }^{+}$Calcd for $\mathrm{C}_{20} \mathrm{H}_{17} \mathrm{IO}_{3}{ }^{+} 432.0217$; Found 432.0210 .

2-(2-Chloroethoxy)-4-phenylbut-3-yn-1-yl 2-iodobenzoate (10d)<smiles>O=C(OCC(C#Cc1ccccc1)OCCCl)c1ccccc1I</smiles>

Obtained from (2-chloroethoxy)ethene $(9 \mathbf{d}, 0.038 \mathrm{~mL}, 0.38 \mathrm{mmol}$, 1.5 equiv); $\operatorname{PhEBX}(\mathbf{2}, 0.087 \mathrm{~g}, 0.25 \mathrm{mmol}, 1.0$ equiv); $\operatorname{BIOAc}(\mathbf{7}, 0.038$ g, $0.13 \mathrm{mmol}, 0.5$ equiv) and $4-\mathrm{ClCZIPN}(\mathbf{4 b}, 5 \mathrm{mg}, 5$ umol, $2 \mathrm{~mol} \%)$ after 18 hours.

Column: Pentane:Et $\mathrm{O}_{2} \mathrm{O}$, 95:5 to 90:10. Some fractions were not pure and were purified by preparative TLC (Pentane:Et ${ }_{2} \mathrm{O}$ 93:7). Combined yield $77 \%$ ( $0.088 \mathrm{~g}, 0.19 \mathrm{mmol},>90 \%$ pure). Pale yellow oil with residual grease.

Rf (Pentane:EtOac 9:1) $=0.7$.

${ }^{1} \mathbf{H}$ NMR $(400 \mathrm{MHz}$, Chloroform- $d) \delta 8.01(\mathrm{dd}, J=8.0,1.2 \mathrm{~Hz}, 1 \mathrm{H}, \mathrm{ArH}), 7.90(\mathrm{dd}, J=7.8,1.7 \mathrm{~Hz}, 1 \mathrm{H}$, $\operatorname{ArH}), 7.48-7.43(\mathrm{~m}, 2 \mathrm{H}, \mathrm{PhH}), 7.43-7.37(\mathrm{~m}, 1 \mathrm{H}, \mathrm{ArH}), 7.36-7.30(\mathrm{~m}, 3 \mathrm{H}, \mathrm{PhH}), 7.17(\mathrm{td}, J=7.7,1.7$ $\mathrm{Hz}, 1 \mathrm{H}, \mathrm{ArH}), 4.79(\mathrm{dd}, J=6.2,5.3 \mathrm{~Hz}, 1 \mathrm{H}, \mathrm{OCH}), 4.69-4.53\left(\mathrm{~m}, 2 \mathrm{H}, \mathrm{OCH}_{2}\right), 4.11(\mathrm{dt}, J=10.5,5.7 \mathrm{~Hz}$, $\left.1 \mathrm{H}, \mathrm{OCH}_{2}\right), 3.85\left(\mathrm{ddd}, J=10.5,6.5,5.6 \mathrm{~Hz}, 1 \mathrm{H}, \mathrm{OCH}_{2}\right), 3.78-3.66\left(\mathrm{~m}, 2 \mathrm{H}, \mathrm{CH}_{2} \mathrm{Cl}\right) .{ }^{13} \mathrm{C} \mathbf{N M R}(101 \mathrm{MHz}$, Chloroform-d) $\delta 166.0,141.4,134.5,132.9,131.9,131.4,128.9,128.4,128.0,121.9,94.3,87.9,83.6$,

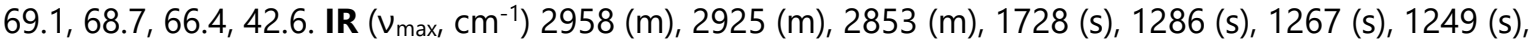
1120 (s), 1102 (s), 1015 (s). HRMS (ESI/QTOF) m/z: [M + Na] ${ }^{+}$Calcd for $\mathrm{C}_{19} \mathrm{H}_{16} \mathrm{ClINaO}_{3}{ }^{+}$476.9725; Found 476.9733.

\section{2-Cyclohexyloxy-4-phenylbut-1-yn-4-yl 2-iodobenzoate (10e)}

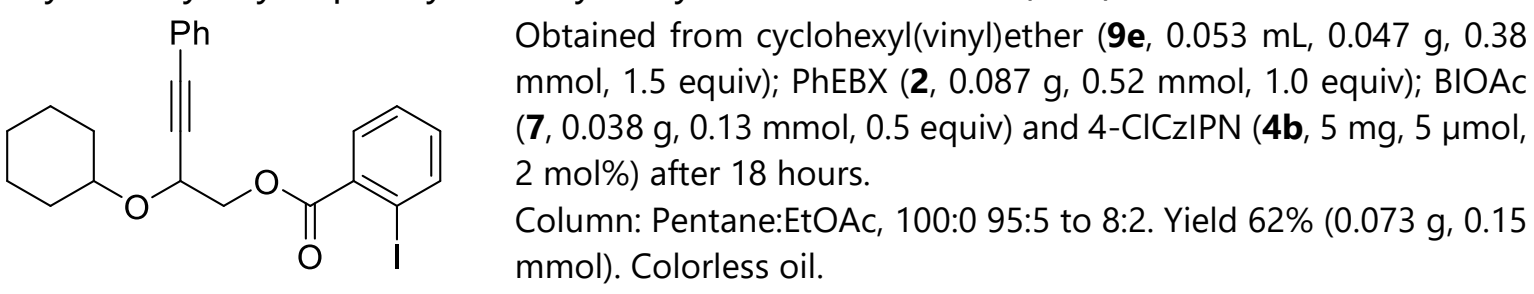

Rf (Pentane:EtOac 9:1) $=0.7$.

${ }^{1} \mathbf{H}$ NMR $(400 \mathrm{MHz}$, Chloroform- $d) \delta 8.00(\mathrm{dd}, J=7.9,1.2 \mathrm{~Hz}, 1 \mathrm{H}, \mathrm{ArH}), 7.89(\mathrm{dd}, J=7.8,1.7 \mathrm{~Hz}, 1 \mathrm{H}$, ArH) $, 7.47-7.43(\mathrm{~m}, 2 \mathrm{H}, \mathrm{PhH}), 7.42-7.36(\mathrm{~m}, 1 \mathrm{H}, \mathrm{ArH}), 7.36-7.28(\mathrm{~m}, 3 \mathrm{H}, \mathrm{PhH}), 7.16(\mathrm{ddd}, J=7.9$, $7.4,1.7 \mathrm{~Hz}, 1 \mathrm{H}, \mathrm{ArH}), 4.80(\mathrm{dd}, J=7.4,4.5 \mathrm{~Hz}, 1 \mathrm{H}, \mathrm{OCH}), 4.61-4.46\left(\mathrm{~m}, 2 \mathrm{H}, \mathrm{OCH}_{2}\right), 3.70(\mathrm{tt}, J=9.3,3.8$ $\mathrm{Hz}, 1 \mathrm{H}, \mathrm{CyH}), 2.06-1.84(\mathrm{~m}, 2 \mathrm{H}, \mathrm{CyH}), 1.84-1.65(\mathrm{~m}, 2 \mathrm{H}, \mathrm{CyH}), 1.62-1.40(\mathrm{~m}, 2 \mathrm{H}, \mathrm{CyH}), 1.40-1.17$ $(\mathrm{m}, 4 \mathrm{H}, \mathrm{CyH}) .{ }^{13} \mathrm{C}$ NMR $(101 \mathrm{MHz}$, Chloroform-d) $\delta 166.1,141.4,134.7,132.8,131.8,131.3,128.6$, 128.3, 127.9, 122.4, 94.4, 86.2, 85.6, 67.2, 65.4, 33.2, 31.5, 25.7, 24.0. IR $\left(\mathrm{v}_{\max } \mathrm{cm}^{-1}\right) 2997$ (s), 2987 (s), 2971 (s), 2933 (s), 2901 (s), 1725 (s), 1287 (s), 1243 (s), 1133 (s), 1098 (s), 1075 (s), 1038 (s), 1016 (s). HRMS (ESI/QTOF) m/z: [M + Na] ${ }^{+}$Calcd for $\mathrm{C}_{23} \mathrm{H}_{23} \mathrm{INaO}_{3}{ }^{+}$497.0584; Found 497.0592. 
2-Ethoxy-2-methyl-4-phenylbut-1-yn-4-yl 2-iodobenzoate (10f)<smiles>CCOC(C)(C#Cc1ccccc1)COC(=O)c1ccccc1I</smiles>

Obtained from 2-ethoxypro-1-ene ( 9 ff, $42 \mu \mathrm{L}, 0.37 \mathrm{mmol}, 1.5$ equiv); $\operatorname{PhEBX}(\mathbf{2}, 0.087 \mathrm{~g}, 0.25 \mathrm{mmol}, 1.0$ equiv); $\operatorname{BIOAc}(\mathbf{7}, 0.038 \mathrm{~g}, 0.15$ mmol, 0.5 equiv) and 4-ClCzIPN (4b, 5 mg, 5 Hmol, 2 mol\%) after 18 hours.

Column: Pentane:EtOAc, 9:1 to 7:3. Yield $82 \%(0.089 \mathrm{~g}, 0.21 \mathrm{mmol})$. Colorless oil.

Rf (Pentane:EtOAc 9:1) $=0.2$

${ }^{1} \mathbf{H}$ NMR $(400 \mathrm{MHz}$, Chloroform- $d) \delta 7.91(\mathrm{dd}, J=8.0,1.2 \mathrm{~Hz}, 1 \mathrm{H}, \mathrm{ArH}), 7.82(\mathrm{dd}, J=7.8,1.7 \mathrm{~Hz}, 1 \mathrm{H}$, $\mathrm{ArH}), 7.38-7.26(\mathrm{~m}, 3 \mathrm{H}, \mathrm{ArH}+\mathrm{PhH}), 7.26-7.19(\mathrm{~m}, 3 \mathrm{H}, \mathrm{PhH}), 7.06(\mathrm{ddd}, J=8.0,7.4,1.7 \mathrm{~Hz}, 1 \mathrm{H}, \mathrm{ArH})$, $4.51(\mathrm{~d}, J=11.2 \mathrm{~Hz}, 1 \mathrm{H}, \mathrm{OCH}), 4.35\left(\mathrm{~d}, J=11.2 \mathrm{~Hz}, 1 \mathrm{H}, \mathrm{OCH}_{2}\right), 3.74-3.64\left(\mathrm{q}, J=7.0 \mathrm{~Hz}, 2 \mathrm{H}, \mathrm{OCH}_{2} \mathrm{CH}_{3}\right)$, $1.57(\mathrm{~s}, 3 \mathrm{H}, \mathrm{Me}), 1.17\left(\mathrm{t}, J=7.0 \mathrm{~Hz}, 3 \mathrm{H}, \mathrm{OCH}_{2} \mathrm{CH}_{3}\right) .{ }^{13} \mathrm{C}$ NMR (101 MHz, Chloroform-d) $\delta 166.0,141.4$, $134.8,132.8,131.8,131.3,128.6,128.3,127.9,122.3,94.4,87.7,86.6,72.3,69.0,60.2,24.8,15.8$. IR $\left(v_{\max }, \mathrm{cm}^{-1}\right) 3004(\mathrm{~s}), 2987(\mathrm{~s}), 2972(\mathrm{~s}), 2911(\mathrm{~s}), 2901(\mathrm{~s}), 2883(\mathrm{~s}), 1732(\mathrm{~s}), 1379(\mathrm{~s}), 1288(\mathrm{~s}), 1243(\mathrm{~s})$, 1125 (s), 1099 (s), 1066 (s), 1046 (s), 1016 (s). HRMS (ESI/QTOF) m/z: [M + Na] ${ }^{+}$Calcd for $\mathrm{C}_{20} \mathrm{H}_{19} \mathrm{INaO}_{3}+457.0271 ;$ Found 457.0272 .

1-(Benzyloxy)-2-(phenylethynyl)hexyl 2-iodobenzoate (10ga) and 3-(benzyloxy)-1phenyloct-1-yn-4-yl 2-iodobenzoate (10gb)

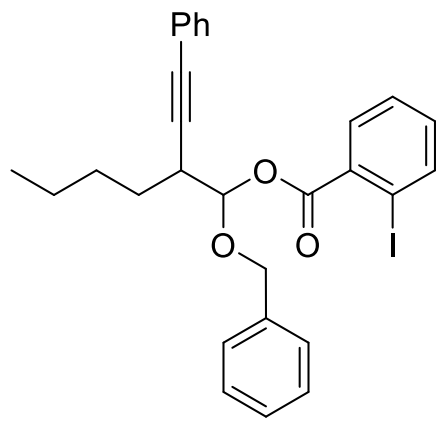

Obtained from (E)-((hex-1-en-1-yloxy)methyl)benzene $(0.071 \mathrm{~g}$, $0.38 \mathrm{mmol}, 1.5$ equiv); $\operatorname{PhEBX}(\mathbf{2}, 0.087 \mathrm{~g}, 0.25 \mathrm{mmol}, 1.0$ equiv); $\operatorname{BIOAC}(\mathbf{7}, 0.038 \mathrm{~g}, 0.13 \mathrm{mmol}, 0.5$ equiv) and $4-\mathrm{CICZIPN}(\mathbf{4 b}, 4 \mathrm{mg}$, $4 \mu \mathrm{mol}, 2 \mathrm{~mol} \%)$ after 18 hours.

First column: Pentane:EtOAc, 100:0 to 90:10, then second column: Pentane:EtOAc 98:2 to 92:8. Fraction 1: 10ga (0.015 g, 0.028 mmol, $11 \%$ yield). Pale yellow oil. Fraction 2 (based on $1 \mathrm{H} \mathrm{NMR}$ analysis): $\mathbf{1 0 g b}$ (85 mol\% and wt\%) 10ga (15 mol\% and wt\%) overall mass $0.014 \mathrm{~g}, 0.026 \mathrm{mmol}$. Pale yellow oil.

Overall yields:

10ga: $0.015 \mathrm{~g}+0.002 \mathrm{~g}=0.017 \mathrm{~g}, 0.032 \mathrm{mmol}, 13 \%$ yield

10gb: $0.015 \mathrm{~g}-0.002 \mathrm{~g}=0.013 \mathrm{~g}, 0.024 \mathrm{mmol}, 10 \%$ yield

Major product $10 \mathrm{ga}$ as a 1:1 mixture of diastereoisomers based on $\mathrm{OCH}_{2} \mathrm{Ph}$ signals: $4.72 \mathrm{ppm}$ and 4.69 ppm:

${ }^{1} \mathbf{H}$ NMR $(400 \mathrm{MHz}$, Chloroform- $d, 1: 1$ mixture of diastereoisomers) $\delta 7.94$ (ddd, $J=7.8,6.5,1.3 \mathrm{~Hz}$, $1 \mathrm{H}, \mathrm{ArH}), 7.79(\mathrm{ddd}, J=7.9,6.8,1.8 \mathrm{~Hz}, 1 \mathrm{H}, \mathrm{ArH}), 7.37-7.16(\mathrm{~m}, 11 \mathrm{H}, \mathrm{PhH}+\mathrm{ArH}), 7.09(\mathrm{tdd}, J=7.9$, $6.2,1.8 \mathrm{~Hz}, 1 \mathrm{H}, \mathrm{ArH}), 6.18\left(\mathrm{~m}, 1 \mathrm{H}, \mathrm{O}_{2} \mathrm{CH}\right), 4.86\left(\mathrm{~d}, J=6.7 \mathrm{~Hz}, 0.5 \mathrm{H}, \mathrm{OCH}_{2} \mathrm{Ph}\right), 4.83(\mathrm{~d}, J=6.6 \mathrm{~Hz}, 0.5 \mathrm{H}$, $\left.\mathrm{OCH}_{2} \mathrm{Ph}\right), 4.72\left(\mathrm{~d}, J=7.2 \mathrm{~Hz}, 0.5 \mathrm{H}, \mathrm{OCH}_{2} \mathrm{Ph}\right), 4.69\left(\mathrm{~d}, J=7.1 \mathrm{~Hz}, 0.5 \mathrm{H}, \mathrm{OCH}_{2} \mathrm{Ph}\right), 3.04\left(\mathrm{dt}_{\mathrm{app}} J=9.9,5.0\right.$ $\mathrm{Hz}, 1 \mathrm{H}, \mathrm{CHR}$-alkyne), $1.77-1.45\left(\mathrm{~m}, 2 \mathrm{H}, \mathrm{CH}_{2}-\mathrm{CH}_{2}-\mathrm{CH}_{2}-\mathrm{CH}_{3}\right), 1.43-1.13\left(\mathrm{~m}, 4 \mathrm{H}, \mathrm{CH}_{2}-\mathrm{CH}_{2}-\mathrm{CH}_{2}-\mathrm{CH}_{3}\right)$, $0.84\left(\mathrm{t}, J=7.2 \mathrm{~Hz}, 3 \mathrm{H}, \mathrm{CH}_{2}-\mathrm{CH}_{2}-\mathrm{CH}_{2}-\mathrm{CH}_{3}\right) .{ }^{13} \mathrm{C}$ NMR $(101 \mathrm{MHz}$, Chloroform-d, mixture of diasteroisomers, not all carbons are resolved) $\delta 166.2,166.1,141.5,141.3,137.1,137.0,134.8,134.6$, $132.9,132.8,131.8,131.7,131.2,131.2,128.5,128.4,128.2,128.1,128.0,128.0,127.9,127.9,123.5$, $123.4,98.9,98.6,88.0,87.9,83.5,72.0,72.0,38.3,38.1,29.7,29.4,29.4,29.1,22.5,22.5,14.0$. IR $\left(v_{\max }\right.$ $\left.\mathrm{cm}^{-1}\right) 3076(\mathrm{w}), 2986(\mathrm{~s}), 2972(\mathrm{~s}), 2931(\mathrm{~m}), 2917(\mathrm{~s}), 2893(\mathrm{~m}), 1728(\mathrm{~m}), 1454(\mathrm{~m}), 1402(\mathrm{~m}), 1271(\mathrm{~m})$, $1242(\mathrm{~m}), 1090$ (s), 1064 (s), 1050 (s). HRMS (ESI/QTOF) m/z: [M + K] ${ }^{+}$Calcd for $\mathrm{C}_{28} \mathrm{H}_{27} \mathrm{IKO}_{3}{ }^{+} 577.0636$; Found 577.0647. 
<smiles>CCCCC(OC(=O)c1ccccc1I)C(C#Cc1ccccc1)OCc1ccccc1</smiles>

Minor product $\mathbf{1 0 g} \mathbf{g}$ as a 1:1 mixture of diastereoisomers based on peak at $4.90 \mathrm{ppm}$, isolated with $15 \%$ of $\mathbf{1 0 g a}$.

For ease of interpretation: the ${ }^{1} \mathrm{H}$ NMR data is reported without the signals corresponding to $\mathbf{1 0 g a}$; the ${ }^{13} \mathrm{C}$ NMR data is reported as measured.

${ }^{1}$ H NMR $(400 \mathrm{MHz}$, Chloroform-d) $\delta 7.99$ (dd, $J=8.0,1.3 \mathrm{~Hz}, 1 \mathrm{H}, \mathrm{ArH}), 7.83$ (ddd, $J=9.7,7.8,1.8 \mathrm{~Hz}$, $1 \mathrm{H}, \mathrm{ArH}), 7.47-7.43(\mathrm{~m}, 2 \mathrm{H}, \mathrm{PhH}), 7.40-7.24(\mathrm{~m}, 9 \mathrm{H}, \mathrm{PhH}+\mathrm{ArH}), 7.14(\mathrm{tt}, J=7.5,1.5 \mathrm{~Hz}, 1 \mathrm{H}, \mathrm{ArH})$, $5.43(\mathrm{tdd}, J=8.5,6.0,4.3 \mathrm{~Hz}, 1 \mathrm{H}, \mathrm{OCH}), 4.90\left(\mathrm{~d}, 0.5 \mathrm{H}, 1\right.$ diastereoisomer, $\left.\mathrm{OCH}_{2} \mathrm{Ph}\right), 4.90(\mathrm{~d}, 0.5 \mathrm{H}, 1$ diastereoisomer, $\left.\mathrm{OCH}_{2} \mathrm{Ph}\right), 4.65\left(\mathrm{~d}, J=12.0 \mathrm{~Hz}, 1 \mathrm{H}, \mathrm{OCH}_{2} \mathrm{Ph}\right), 4.59-4.53(\mathrm{~m}, 1 \mathrm{H}, \mathrm{OCH}), 2.04-1.86(\mathrm{~m}$, $\left.1 \mathrm{H}, \mathrm{CH}_{2}-\mathrm{CH}_{2}-\mathrm{CH}_{2}-\mathrm{CH}_{3}\right), 1.47-1.30\left(\mathrm{~m}, 3 \mathrm{H}, \mathrm{CH}_{2}-\mathrm{CH}_{2}-\mathrm{CH}_{2}-\mathrm{CH}_{3}\right), 0.95-0.82\left(\mathrm{~m}, 5 \mathrm{H}, \mathrm{CH}_{2}-\mathrm{CH}_{2}-\mathrm{CH}_{2}-\mathrm{CH}_{3}\right)$. ${ }^{13} \mathrm{C}$ NMR $(101 \mathrm{MHz}$, Chloroform-d) $\delta 166.1,166.0,141.5,141.3,137.6,135.4,135.2,134.6,132.9,132.6$, $132.5,131.9,131.8,131.2,131.1,131.1,128.7,128.6,128.4,128.4,128.4,128.3,128.3,128.2,128.1$, 128.0, 128.0, 127.9, 127.9, 127.8, 125.5, 122.4, 122.4, 98.6, 94.2, 94.2, 87.7, 87.5, 84.8, 76.0, 75.6, 72.0, $70.9,70.7,70.5,66.7,38.8,38.1,34.5,31.9,30.4,30.3,29.9,29.7,29.6,29.6,29.5,29.4,29.2,28.9,27.7$, 27.5, 25.1, 23.8, 23.0, 22.7, 22.6, 22.5, 14.1, 14.1, 14.0, 11.0. IR $\left(\nu_{\left.\max , \mathrm{cm}^{-1}\right)} 3009(\mathrm{~m}), 2996(\mathrm{~m}), 2931\right.$ $(\mathrm{m}), 2916(\mathrm{~s}), 2908(\mathrm{~m}), 2892(\mathrm{~m}), 1732(\mathrm{~m}), 1394(\mathrm{~m}), 1089(\mathrm{~m}), 1076(\mathrm{~s}), 1062(\mathrm{~s}), 1024(\mathrm{~m})$. HRMS (ESI/QTOF) m/z: $[\mathrm{M}+\mathrm{K}]^{+}$Calcd for $\mathrm{C}_{28} \mathrm{H}_{27} \mathrm{KO}_{3}{ }^{+}$577.0636; Found 577.0646 .

\section{2-(Phenylethynyl)tetrahydro-2H-pyran-3-yl 2-iodobenzoate (10ha) 3-} (phenylethynyl)tetrahydro-2H-pyran-2-yl 2-iodobenzoate (10hb); 4:1 regioisomeric mixture<smiles>O=C(OC1CCCOC1C#Cc1ccccc1)c1ccccc1I</smiles>

$58 \%$<smiles>O=C(OC1OCCCC1C#Cc1ccccc1)c1ccccc1I</smiles>

$15 \%$

Obtained from 2,3-dihydropyran (9h, $34 \mu \mathrm{L}$, 0.38 mmol, 1.5 equiv); $\operatorname{PhEBX}(\mathbf{2}, 0.087 \mathrm{~g}, 0.25$ mmol, 1.0 equiv); $\operatorname{BIOAc}(\mathbf{7}, 0.114 \mathrm{~g}, 0.1 \mathrm{mmol}$,

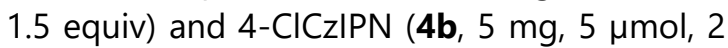
mol\%) after 18 hours.

Column: Pentane:EtOAc, 9:1 to 8:2. Yield $73 \%$ $(0.076 \mathrm{~g}, 0.17 \mathrm{mmol})$. Yellow oil.

Rf (pentane:EtOAc 9:1) $=0.3$

${ }^{1} \mathbf{H}$ NMR (400 MHz, Chloroform-d, 8:2 mixture of regioisomers major in bold, minor in italic those corresponding to both are both bold and italic) $\delta 8.02(\mathrm{dd}, J=7.6,1.2 \mathrm{~Hz}, 0.2 \mathrm{H}$, minor, $\operatorname{ArH}), 8.00$ $(\mathrm{dd}, J=7.9,1.2 \mathrm{~Hz}, 0.8 \mathrm{H}$, major, $\operatorname{Ar} H), 7.91(\mathrm{dd}, J=7.8,1.7 \mathrm{~Hz}, 0.2 \mathrm{H}$, minor, $\operatorname{ArH}), \mathbf{7 . 8 6}(\mathrm{dd}, J=7.8,1.7$ $\mathrm{Hz}, 0.8 \mathrm{H}$, major, $\mathrm{ArH}), \mathbf{7 . 4 8}$ - $7.36(\mathrm{~m}, 3 \mathrm{H}, \mathrm{PhH}), 7.37$ - $7.26(\mathrm{~m}, 3 \mathrm{H}, \mathrm{PhH}+\mathrm{ArH}), \mathbf{7 . 2 0}-\mathbf{7 . 1 2}(\mathrm{m}, 1 \mathrm{H}$, $\mathrm{ArH}), 6.19\left(\mathrm{~d}, J=4.4 \mathrm{~Hz}, 0.2 \mathrm{H}\right.$, minor, $\left.\mathrm{ArCO}_{2}-\mathrm{CHR}-\mathrm{OR}\right), \mathbf{5 . 2 4}-\mathbf{5 . 1 4}(\mathrm{m}, 0.8 \mathrm{H}$, major, alkynyl-CHR-OR), $4.74\left(\mathrm{~d}, J=5.3 \mathrm{~Hz}, 0.8 \mathrm{H}\right.$, major, $\left.\mathrm{ArCO}_{2}-\mathrm{CHR}_{2}\right), 4.11$ (ddd, $\left.J=11.6,7.7,3.5 \mathrm{~Hz}, 1 \mathrm{H}, \mathrm{RO}-\mathrm{CH}_{2} \mathrm{R}\right), 3.70$ (ddd, $\left.J=11.1,6.3,3.7 \mathrm{~Hz}, 1 \mathrm{H}, \mathrm{RO}-\mathrm{CH}_{2} \mathrm{R}\right), 3.06(\mathrm{dt}, J=6.5,4.5 \mathrm{~Hz}, 0.2 \mathrm{H}$, alkynyl-CHR2, minor), 2.36 (ddd, $J=$ 13.1, 8.8, 4.2 Hz, $\left.1 \mathrm{H}, \mathrm{CH}_{2}\right), 2.06-1.85\left(\mathrm{~m}, 2 \mathrm{H}, \mathrm{CH}_{2}\right), \mathbf{1 . 6 9}\left(\mathrm{dtt}, J=13.3,6.9,3.8 \mathrm{~Hz}, 1 \mathrm{H}, \mathrm{CH}_{2}\right) .{ }^{13} \mathbf{C} \mathbf{~ N M R}$ (101 MHz, Chloroform- $d$, mixture of regioisomers some carbons are not resolved) $\delta 165.7,141.5$, $141.3,135.0,133.0,132.8,131.9,131.8,131.4,131.1,128.7,128.3,128.2,128.1,128.0,122.2,95.3,94.2$, 87.8, 87.6, 84.6, 72.0, 69.0, 64.9, 64.4, 32.4, 29.7, 26.2, 25.8, 22.5, 22.3. IR $\left(\nu_{\max ,} \mathrm{cm}^{-1}\right) 3060(\mathrm{~m}), 2987(\mathrm{~s})$, $2901(\mathrm{~s}), 1725(\mathrm{~m}), 1428(\mathrm{~m}), 1379(\mathrm{~m}), 1249(\mathrm{~s}), 1078(\mathrm{~s}), 1044$ (s). HRMS (ESI/QTOF) m/z: [M + $\mathrm{Na}]^{+}$Calcd for $\mathrm{C}_{20} \mathrm{H}_{17} \mathrm{INaO}_{3}{ }^{+}$455.0115; Found 455.0122 . 
2-(((Benzyloxy)carbonyl)(phenethyl)amino)-4-(4-(trifluoromethyl)phenyl)but-3-yn-1yl 2-iodobenzoate (12a)<smiles>CC(=O)N(CCc1ccccc1)C(C#Cc1ccc(C(F)(F)F)cc1)COC(=O)c1ccccc1I</smiles>

Rf (Pent.:EtOAc 9:1) $=0.25$.

${ }^{1} \mathbf{H}$ NMR (400 MHz, Acetonitrile- $d_{3}, 6: 4$ mixture of rotamers) $\delta 8.02(\mathrm{dd}, J=8.0,1.1 \mathrm{~Hz}, 1 \mathrm{H}, \mathrm{ArH}), 7.88$ - $7.72(\mathrm{~m}, 1 \mathrm{H}, \mathrm{ArH}), 7.72-7.56(\mathrm{~m}, 5 \mathrm{H}, \mathrm{PhH}+\mathrm{ArH}), 7.50-7.06(\mathrm{~m}, 11 \mathrm{H}, \mathrm{PhH}+\mathrm{ArH}), 5.65(\mathrm{bs}, 0.6 \mathrm{H}$, major, $\mathrm{NCH}), 5.50$ (bs, 0.4H, minor, $\mathrm{NCH}), 5.13\left(\mathrm{~m}, 2 \mathrm{H}, \mathrm{PhCH} \mathrm{H}_{2} \mathrm{O}\right), 4.72-4.41\left(\mathrm{~m}, 2 \mathrm{H}, \mathrm{OCH}_{2}\right), 3.62(\mathrm{t}, J=$ $\left.8.1 \mathrm{~Hz}, 2 \mathrm{H}, \mathrm{CH}_{2}\right), 3.17-2.85\left(\mathrm{~m}, 2 \mathrm{H}, \mathrm{CH}_{2}\right) .{ }^{13} \mathrm{C}$ NMR $\left(101 \mathrm{MHz}\right.$, Acetonitrile- $d_{3}$, mixture of rotamers, 2 carbons not resolved) $\delta 166.4,156.4,141.9,139.7,137.3,135.5,133.7,132.8,131.4,130.41(q, J=32.6$ $\mathrm{Hz}), 129.3,129.1,129.0,128.9,128.76-128.28(\mathrm{~m}), 126.9,126.6,(q, J=4.0 \mathrm{~Hz}), 123.3,93.9,86.9,85.0$, 67.8, 65.0, 48.7, 47.2, 36.5. ${ }^{19}$ F NMR (376 MHz, Acetonitrile-d $\left.d_{3}\right) \delta$-63.4. IR $\left(v_{\max } \mathrm{cm}^{-1}\right) 2986(\mathrm{~s}), 2970$ (s), 2961 (s), 2934 (s), 2901 (s), 1733 (s), 1715 (s), 1705 (s), 1699 (s), 1685 (s), 1410 (s), 1322 (s), 1247 (s). HRMS (ESI/QTOF) m/z: [M + H] ${ }^{+}$Calcd for $\mathrm{C}_{34} \mathrm{H}_{28} \mathrm{~F}_{3} \mathrm{INO}_{4}{ }^{+}$698.1010; Found 698.1006.

2-(((Benzyloxy)carbonyl)(phenethyl)amino)-4-(4-bromophenyl)but-3-yn-1-yl iodobenzoate (12b)<smiles>O=C(OCC(C#Cc1ccc(Br)cc1)N(CCc1ccccc1)Cc1ccccc1)c1ccccc1I</smiles>

Obtained from benzyl phenethyl(vinyl)carbamate (1c, $0.106 \mathrm{~g}$, $0.375 \mathrm{mmol}, 1.2$ equiv); $p$ BrPhEBX (11 b, $0.107 \mathrm{~g}, 0.250 \mathrm{mmol}, 1.0$ equiv); $\mathrm{BIOAC}(\mathbf{7}, 0.038 \mathrm{~g}, 0.13 \mathrm{mmol}, 0.5$ equiv) and $4-\mathrm{CICzIPN}(\mathbf{4 b}$, $4 \mathrm{mg}, 5 \mu \mathrm{mol}, 2 \mathrm{~mol} \%)$ after 18 hours.

Column: Pentane:EtOAc, 10:0 to 9:1. Yield 76\% (0.191 g, 0.135 mmol). Pale yellow oil.

Rf (Pent::EtOAc 9:1) $=0.25$.

${ }^{1} \mathbf{H}$ NMR $\left(400 \mathrm{MHz}\right.$, Acetonitrile- $\left.d_{3}\right) \delta 8.05(\mathrm{~d}, J=7.9 \mathrm{~Hz}, 1 \mathrm{H}), 7.77(\mathrm{~d}, J=7.8 \mathrm{~Hz}, 1 \mathrm{H}), 7.57(\mathrm{~d}, J=8.2$ $\mathrm{Hz}, 2 \mathrm{H}), 7.52-7.07(\mathrm{~m}, 13 \mathrm{H}), 5.61(\mathrm{~s}, 1 \mathrm{H}), 5.22-5.03(\mathrm{~m}, 2 \mathrm{H}), 4.66-4.47(\mathrm{~m}, 2 \mathrm{H}), 3.63(\mathrm{dq}, J=15.1$, $7.6 \mathrm{~Hz}, 2 \mathrm{H}), 3.36(\mathrm{q}, J=6.8 \mathrm{~Hz}, 0 \mathrm{H}), 3.03(\mathrm{dq}, J=16.5,8.6,7.3 \mathrm{~Hz}, 2 \mathrm{H}), 2.80(\mathrm{t}, J=7.2 \mathrm{~Hz}, 0 \mathrm{H})$.

${ }^{1} \mathbf{H}$ NMR $\left(400 \mathrm{MHz}\right.$, Acetonitrile- $d_{3,}$ 9:1 mixture of rotamers) ${ }^{31} \delta 8.05(\mathrm{dd}, J=8.0,1.1 \mathrm{~Hz}, 1 \mathrm{H}, \mathrm{ArH}), 7.80$ - $7.73(\mathrm{~m}, 1 \mathrm{H}, \mathrm{ArH}), 7.61-7.53(\mathrm{~m}, 2 \mathrm{H}, \mathrm{ArH}$ or PhH), $7.47(\mathrm{td}, J=7.6,1.2 \mathrm{~Hz}, 1 \mathrm{H}, \mathrm{ArH}), 7.43-7.25(\mathrm{~m}$, $7 \mathrm{H}, \mathrm{PhH}+\mathrm{ArH}), 7.29-7.16(\mathrm{~m}, 5 \mathrm{H}, \mathrm{ArH}), 7.16-7.11(\mathrm{~m}, 1 \mathrm{H}, \mathrm{ArH}), 5.61-\left(\mathrm{bs},{ }^{\circ} 0.7 \mathrm{H}^{\prime}\right.$, major, $\left.\mathrm{NCH}\right), 5.48$ (bs, "0.3H", minor, $\mathrm{NCH}), 5.15\left(\mathrm{~m}, 2 \mathrm{H}, \mathrm{PhCH}_{2} \mathrm{O}\right), 4.56\left(\mathrm{q}, J=5.4,4.3 \mathrm{~Hz}, 2 \mathrm{H}, \mathrm{OCH}_{2}\right), 3.64(\mathrm{dq}, J=17.8$, 7.6, $7.2 \mathrm{~Hz}, 1.8 \mathrm{H}$, major, $\left.\mathrm{CH}_{2}\right), 3.36\left(\mathrm{q}, J=6.8 \mathrm{~Hz}, 0.2 \mathrm{H}\right.$, minor, $\left.\mathrm{CH}_{2}\right), 3.00(\mathrm{t}, J=8.6 \mathrm{~Hz}, 1.8 \mathrm{H}$, major, $\left.\mathrm{CH}_{2}\right), 2.80\left(\mathrm{t}, J=7.2 \mathrm{~Hz}, 0.2 \mathrm{H}\right.$, minor, $\left.\mathrm{CH}_{2}\right) .{ }^{13} \mathrm{C}$ NMR $\left(101 \mathrm{MHz}\right.$, Acetonitrile- $d_{3}$, mixture of rotamers,

\footnotetext{
${ }^{31}$ The rotamer ratio was based on the signals at 3.00 and $2.80 \mathrm{ppm}$ as they are better defined; the proton signals associated to the $\mathrm{NCH}$ (5.61 and $5.48 \mathrm{ppm}$ ) are broad signals therefore precise integration cannot be guaranteed.
} 
not all peaks are resolved) $\delta 166.4,156.4,141.9,139.8,137.4,135.5,133.9,133.7,132.4,132.1,131.4$, 129.3, 129.1, 129.0, 128.9, 128.9, 128.6, 126.9, 123.3, 121.7, 93.9, 85.5, 85.3, 67.8, 65.1, 48.7, 47.1, 36.5 . IR $\left(v_{\max } \mathrm{cm}^{-1}\right) 2987(\mathrm{~s}), 2972(\mathrm{~s}), 2901(\mathrm{~s}), 1749(\mathrm{~s}), 1470(\mathrm{~s}), 1419(\mathrm{~s}), 1376(\mathrm{~s}), 1286(\mathrm{~s}), 1242(\mathrm{~s}), 1133$ (s), 1076 (s), 1048 (s), 1017 (s). HRMS (ESI/QTOF) m/z: [M + Na $]^{+}$Calcd for $\mathrm{C}_{20} \mathrm{H}_{15}{ }^{79} \mathrm{BrINNaO}_{4}{ }^{+}$ 561.9121; Found 561.9118.

4-(2-Bromophenyl)-2-(2-oxooxazolidin-3-yl)but-3-yn-1-yl 2-iodobenzoate (12c)<smiles>O=C(OCC(C#Cc1ccccc1Br)N1CCOC1=O)c1ccccc1I</smiles>
Obtained from $N$-vinyloxazolidin-2-one $(1 \mathbf{a}, 0.042 \mathrm{~g}, 0.37 \mathrm{mmol}$, 1.5 equiv); oBrPhEBX (11c, $0.107 \mathrm{~g}, 0.250 \mathrm{mmol}, 1.0$ equiv); BIOAc $(\mathbf{7}, 0.038 \mathrm{~g}, 0.15 \mathrm{mmol}, 0.5$ equiv) and $4-\mathrm{ClCzIPN}(\mathbf{4 b}, 5 \mathrm{mg}, 5$ mol, 2 mol\%) after 18 hours.

Column: Pentane:EtOAc, 8:2 to 5:5. Yield 56\% (0.080 g, $0.14 \mathrm{mmol})$. Yellow oil.

Rf (Pent:EtOAc 8:2) $=0.25$

${ }^{1}$ H NMR $(400 \mathrm{MHz}$, Chloroform- $d) \delta 8.00(\mathrm{dd}, J=7.9,1.2 \mathrm{~Hz}, 1 \mathrm{H}, \operatorname{ArH}), 7.86(\mathrm{dd}, J=7.8,1.7 \mathrm{~Hz}, 1 \mathrm{H}$, $\operatorname{ArH}), 7.60(\mathrm{dd}, J=8.0,1.3 \mathrm{~Hz}, 1 \mathrm{H}, \operatorname{ArH}), 7.47(\mathrm{dd}, J=7.7,1.8 \mathrm{~Hz}, 1 \mathrm{H}, \operatorname{ArH}), 7.42(\mathrm{td}, J=7.6,1.2 \mathrm{~Hz}, 1 \mathrm{H}$, $\operatorname{ArH}), 7.29(\mathrm{td}, J=7.6,1.3 \mathrm{~Hz}, 1 \mathrm{H}, \mathrm{ArH}), 7.20(\mathrm{dtd}, J=20.1,7.8,1.8 \mathrm{~Hz}, 2 \mathrm{H}, \operatorname{ArH}), 5.41(\mathrm{dd}, J=8.8,4.3$ $\mathrm{Hz}, 1 \mathrm{H}, \mathrm{NCH}), 4.80\left(\mathrm{dd}, J=11.5,8.8 \mathrm{~Hz}, 1 \mathrm{H}, \mathrm{CH}_{2}\right), 4.51\left(\mathrm{dd}, J=11.5,4.3 \mathrm{~Hz}, 1 \mathrm{H}, \mathrm{CH}_{2}\right), 4.48-4.33(\mathrm{~m}$, $\left.2 \mathrm{H}, \mathrm{CH}_{2}\right), 3.96\left(\mathrm{dt}, J=9.4,8.1 \mathrm{~Hz}, 1 \mathrm{H}, \mathrm{CH}_{2}\right), 3.81\left(\mathrm{td}, J=8.6,5.6 \mathrm{~Hz}, 1 \mathrm{H}, \mathrm{CH}_{2}\right) .{ }^{13} \mathrm{C} \mathbf{N M R}(101 \mathrm{MHz}$, Acetonitrile- $\left.d_{3}\right) \delta 166.4,158.5,141.9,135.5,134.3,133.7,133.1,131.5,131.2,128.9,128.2,125.6,124.2$, 93.9, 87.1, 85.4, 64.5, 63.2, 46.4, 42.0. IR ( $\left.\nu_{\max } \mathrm{cm}^{-1}\right) 2987$ (s), 2972 (s), 2901 (s), $1749(\mathrm{~s}), 1470$ (s), 1419 (s), $1376(\mathrm{~s}), 1286(\mathrm{~s}), 1242(\mathrm{~s}), 1133$ (s), 1076 (s), 1048 (s), 1017 (s). HRMS (ESI/QTOF) m/z: [M + $\mathrm{Na}]^{+}$Calcd for $\mathrm{C}_{20} \mathrm{H}_{15}{ }^{79} \mathrm{BrINNaO}_{4}{ }^{+} 561.9121$; Found 561.9118 .

4-(3-Fluorophenyl)-2-(2-oxooxazolidin-3-yl)but-3-yn-1-yl 2-iodobenzoate (12d)<smiles>O=C(OCC(C#Cc1cccc(F)c1)N1CCOC1=O)c1ccccc1I</smiles>

Obtained from $N$-vinyloxazolidin-2-one $(\mathbf{1} \mathbf{a}, 0.042 \mathrm{~g}, 0.37 \mathrm{mmol}$, 1.5 equiv); $m$ FPhEBX (11d, $0.092 \mathrm{~g}, 0.25 \mathrm{mmol}, 1.0$ equiv); $B \operatorname{BIOAc}(\mathbf{7}$, $0.038 \mathrm{~g}, 0.15 \mathrm{mmol}, 0.5$ equiv) and $4-\mathrm{ClC} z \mathrm{IPN}(\mathbf{4 b}, 5 \mathrm{mg}, 5 \mu \mathrm{mol}, 2$ mol\%) after 18 hours.

Column: Pentane:EtOAc, 8:2 to 5:5. Yield 32\% (0.038 g, 0,079 mmol). Yellow oil.

Rf (Pent:EtOAc 8:2) $=0.3$.

${ }^{1} \mathbf{H}$ NMR $(400 \mathrm{MHz}$, Chloroform- $d) \delta 7.92(\mathrm{dd}, J=7.9,1.2 \mathrm{~Hz}, 1 \mathrm{H}, \operatorname{Ar} H), 7.76(\mathrm{dd}, J=7.8,1.7 \mathrm{~Hz}, 1 \mathrm{H}$, $\operatorname{ArH}), 7.34(\mathrm{td}, J=7.6,1.2 \mathrm{~Hz}, 1 \mathrm{H}, \mathrm{ArH}), 7.28-7.18(\mathrm{~m}, 1 \mathrm{H}, \mathrm{ArH}), 7.15(\mathrm{dt}, J=7.7,1.2 \mathrm{~Hz}, 1 \mathrm{H}, \mathrm{ArH}), 7.14$ - $7.02(\mathrm{~m}, 2 \mathrm{H}, \mathrm{ArH}), 7.00$ (tdd, J = 8.4, 2.6, $1.1 \mathrm{~Hz}, 1 \mathrm{H}, \mathrm{ArH}), 5.30(\mathrm{dd}, J=8.9,4.4 \mathrm{~Hz}, 1 \mathrm{H}, \mathrm{NCH}), 4.69$ $\left(\mathrm{dd}, J=11.5,8.9 \mathrm{~Hz}, 1 \mathrm{H}, \mathrm{CH}_{2}\right), 4.44-4.25\left(\mathrm{~m}, 3 \mathrm{H}, \mathrm{CH}_{2}\right), 3.81-3.71\left(\mathrm{~m}, 1 \mathrm{H}, \mathrm{CH}_{2}\right), 3.75-3.66(\mathrm{~m}, 1 \mathrm{H}$, $\left.\mathrm{CH}_{2}\right) .{ }^{13} \mathrm{C}$ NMR $(101 \mathrm{MHz}$, Chloroform- $d) \delta 165.9,162.3(\mathrm{~d}, J=247.3 \mathrm{~Hz}), 157.9,141.5,134.1,133.1$, 131.3, $130.2(\mathrm{~d}, J=8.5 \mathrm{~Hz}), 128.2,127.9(\mathrm{~d}, J=3.1 \mathrm{~Hz}), 123.3(\mathrm{~d}, J=9.3 \mathrm{~Hz}), 118.8(\mathrm{~d}, J=23.0 \mathrm{~Hz})$, $116.6(\mathrm{~d}, J=21.0 \mathrm{~Hz}), 94.3,86.1(\mathrm{~d}, J=3.3 \mathrm{~Hz}), 81.9,63.6,62.4,46.1,41.3 .{ }^{19} \mathbf{F}$ NMR $(377 \mathrm{MHz}$, Chloroform-d) $\delta$-112.3. IR ( $\left.\nu_{\max } \mathrm{cm}^{-1}\right) 2973(\mathrm{~s}), 2932(\mathrm{~m}), 2889(\mathrm{~m}), 1734(\mathrm{~s}), 1581(\mathrm{~s}), 1485(\mathrm{~s}), 1419$ (s), $1376(\mathrm{~s}), 1286(\mathrm{~s}), 1246$ (s), 1226 (s), $1172(\mathrm{~s}), 1152(\mathrm{~s}), 1133$ (s), 1093 (s), 1045 (s), 1016 (s). HRMS (ESI/QTOF) $\mathrm{m} / \mathrm{z}:[\mathrm{M}+\mathrm{H}]^{+}$Calcd for $\mathrm{C}_{20} \mathrm{H}_{16} \mathrm{FINO}_{4}{ }^{+}$480.0103; Found 480.0098 . 
<smiles>Cc1ccc(C#CC(COC(=O)c2ccccc2I)N2CCOC2=O)cc1</smiles>

Rf (Pent:EtOAc 8:2) $=0.3$.

${ }^{1} \mathrm{H}$ NMR $\left(400 \mathrm{MHz}\right.$, Acetonitrile- $\left.d_{3}\right) \delta 8.04(\mathrm{dd}, J=8.0,1.2 \mathrm{~Hz}, 1 \mathrm{H}, \operatorname{ArH}), 7.80(\mathrm{dd}, J=7.8,1.7 \mathrm{~Hz}, 1 \mathrm{H}$, $\operatorname{ArH}), 7.49(\mathrm{td}, J=7.6,1.2 \mathrm{~Hz}, 1 \mathrm{H}, \mathrm{ArH}), 7.41-7.33(\mathrm{~m}, 2 \mathrm{H}, \mathrm{ArH}), 7.25$ (ddd, $J=8.0,7.4,1.7 \mathrm{~Hz}, 1 \mathrm{H}$, $\mathrm{ArH}), 7.22-7.16(\mathrm{~m}, 2 \mathrm{H}, \mathrm{ArH}), 5.23(\mathrm{dd}, J=8.6,4.6 \mathrm{~Hz}, 1 \mathrm{H}, \mathrm{NCH}), 4.65\left(\mathrm{dd}, J=11.4,8.6 \mathrm{~Hz}, 1 \mathrm{H}, \mathrm{CH}_{2}\right)$, $4.49\left(\mathrm{dd}, J=11.4,4.6 \mathrm{~Hz}, 1 \mathrm{H}, \mathrm{CH}_{2}\right), 4.41-4.27\left(\mathrm{~m}, 2 \mathrm{H}, \mathrm{CH}_{2}\right), 3.86-3.70\left(\mathrm{~m}, 2 \mathrm{H}, \mathrm{CH}_{2}\right), 2.34(\mathrm{~s}, 3 \mathrm{H}, \mathrm{Me})$. ${ }^{13} \mathrm{C}$ NMR $\left(101 \mathrm{MHz}\right.$, Acetonitrile- $\left.d_{3}\right) \delta 166.5,158.5,141.8,140.2,135.6,133.7,132.2,131.4,129.8$, 128.9, 119.2, 93.8, 87.2, 81.4, 64.5, 63.2, 46.3, 41.7, 21.1. IR $\left(v_{\text {max }} \mathrm{cm}^{-1}\right) 2998(\mathrm{~s}), 2972$ (s), 2943 (s), 2901 (s), $1748(\mathrm{~s}), 1481(\mathrm{~s}), 1408(\mathrm{~s}), 1377(\mathrm{~s}), 1286(\mathrm{~s}), 1248(\mathrm{~s}), 1075(\mathrm{~s}), 1066$ (s), 1038 (s), 1016 (s). HRMS (ESI/QTOF) $\mathrm{m} / \mathrm{z}:[\mathrm{M}+\mathrm{Na}]^{+}$Calcd for $\mathrm{C}_{21} \mathrm{H}_{18} \mathrm{INNaO}_{4}{ }^{+}$498.0173; Found 498.0182.

2-(((Benzyloxy)carbonyl)(phenethyl)amino)-4-(triisopropylsilyl)but-3-yn-1-yl iodobenzoate (12f)<smiles>O=C(OCC(C#C[SiH2]C(F)(F)F)N(CCc1ccccc1)C(=O)OCc1ccccc1)c1ccccc1I</smiles>

Obtained from benzyl phenethyl(vinyl)carbamate (1c, $0.106 \mathrm{~g}$, $0.375 \mathrm{mmol}, 1.5$ equiv); $11 \mathrm{f}(0.107 \mathrm{~g}, 0.25 \mathrm{mmol}, 1.0$ equiv); BIOAc (7, $0.038 \mathrm{~g}, 0.15 \mathrm{mmol}, 0.5$ equiv) and $4-\mathrm{ClCzIPN}(\mathbf{4 b}, 5 \mathrm{mg}, 5$ rmol, 2 mol\%) after 18 hours.

Column: Pentane:EtOAc, 93:7 to 9:1. Yield $9 \%(0.007 \mathrm{~g}, 0.03 \mathrm{mmol})$. Colorless oil.

$\mathbf{R f}$ (pentane:EtOAc 8:2) $=0.15$.

${ }^{1} \mathbf{H}$ NMR $\left(400 \mathrm{MHz}\right.$, Acetonitrile- $d_{3,} 6: 3$ mixture of rotamers) $\delta 8.02$ (dd, $\left.J=7.9,1.2 \mathrm{~Hz}, 1 \mathrm{H}, \mathrm{ArH}\right), 7.75$ $(\mathrm{d}, J=7.7 \mathrm{~Hz}, 1 \mathrm{H}, \operatorname{ArH}), 7.43(\mathrm{dd}, J=8.4,7.2 \mathrm{~Hz}, 1 \mathrm{H}, \operatorname{ArH}), 7.34(\mathrm{~d}, J=11.1 \mathrm{~Hz}, 6 \mathrm{H}, \mathrm{PhH}+\operatorname{ArH}), 7.29-$ $7.14(\mathrm{~m}, 4 \mathrm{H}, \mathrm{PhH}), 7.13-7.09(\mathrm{~m}, 1 \mathrm{H}, \mathrm{ArH}), 5.45(\mathrm{~s}, 0.6 \mathrm{H}, \mathrm{NCH}), 5.35(\mathrm{~s}, 0.3 \mathrm{H}, \mathrm{NCH}), 5.14(\mathrm{~d}, J=12.4$ $\left.\mathrm{Hz}, 1 \mathrm{H}, \mathrm{PhCH}_{2}\right), 5.09\left(\mathrm{~s}, 1 \mathrm{H}, \mathrm{PhCH}_{2}\right), 4.44\left(\mathrm{dd}, J=6.2,3.6 \mathrm{~Hz}, 2 \mathrm{H}, \mathrm{OCH}_{2}\right), 3.59(\mathrm{dd}, J=10.2,6.8 \mathrm{~Hz}, 2 \mathrm{H}$, $\mathrm{PhCH}_{2}-\mathrm{CH}_{2}$ ), 3.01 (ddd, J = 13.0, 9.5, $\left.6.3 \mathrm{~Hz}, 1 \mathrm{H}, \mathrm{NCH}_{2}\right), 2.93\left(\mathrm{~s}, 1 \mathrm{H}, \mathrm{NCH}_{2}\right), 1.05(\mathrm{~d}, J=2.3 \mathrm{~Hz}, 18 \mathrm{H}$, SiiPr $\left.{ }_{3}\right) .{ }^{13} \mathrm{C}$ NMR $\left(101 \mathrm{MHz}\right.$, Acetonitrile- $\left.d_{3}\right) \delta 166.2,156.2,141.9,139.8,137.4,135.3,133.7,131.5$, $129.4,129.2,129.1,129.0,128.8,128.8,128.6,127.0,126.9,102.4,94.1,88.4,68.9,67.8,65.5,48.8,46.9$, $42.4,36.4,34.5,32.2,29.9,23.0,18.5,18.4,18.3,18.2,17.9,14.0,12.8,11.9,11.5,11.2$. HRMS (ESI/QTOF) m/z: [M + Na] ${ }^{+}$Calcd for $\mathrm{C}_{36} \mathrm{H}_{44} \mathrm{INNaO}_{4} \mathrm{Si}^{+}$732.1977; Found 732.1976.

Unfortunately, insufficient quantities of compound $\mathbf{1 2 f}$ was obtained to allow interpretable IR analysis. 

iodobenzoate $(\mathbf{1 2 g})$<smiles>O=C(OCCCBr)c1ccc(C#CC(COC(=O)c2ccccc2I)N2CCOC2=O)cc1</smiles>

Obtained from $N$-vinyloxazolidin-2-one $(1 \mathbf{a}, 0.042 \mathrm{~g}, 0.37 \mathrm{mmol}$, 1.5 equiv); $11 \mathrm{f}(0.124 \mathrm{~g}, 0.250 \mathrm{mmol}, 1.0$ equiv); $\operatorname{BIOAc}(\mathbf{7}, 0.038 \mathrm{~g}$, $0.15 \mathrm{mmol}, 0.5$ equiv) and $4-\mathrm{ClCZIPN}(\mathbf{4 b}, 5 \mathrm{mg}, 5 \mu \mathrm{mol}, 2 \mathrm{~mol} \%)$ after 18 hours.

Column: Pentane:EtOAc, 8:2 to 5:5. Yield $51 \%(0.077 \mathrm{~g}, 0.12 \mathrm{mmol})$. Yellow oil.

Rf (pentane:EtOAc 8:2) $=0.15$.

${ }^{1} \mathbf{H}$ NMR (400 MHz, Chloroform-d) $\delta 8.04-7.96(\mathrm{~m}, 3, \mathrm{ArH}), 7.83(\mathrm{dd}, J=7.8,1.7 \mathrm{~Hz}, 1 \mathrm{H}, \mathrm{ArH}), 7.55-$ $7.47(\mathrm{~m}, 2 \mathrm{H}, \mathrm{ArH}), 7.42(\mathrm{td}, J=7.6,1.2 \mathrm{~Hz}, 1 \mathrm{H}, \mathrm{ArH}), 7.18(\mathrm{ddd}, J=8.0,7.4,1.7 \mathrm{~Hz}, 1 \mathrm{H}, \mathrm{ArH}), 5.40(\mathrm{dd}$, $J=8.8,4.4 \mathrm{~Hz}, 1 \mathrm{H}, \mathrm{NCH}), 4.78\left(\mathrm{dd}, J=11.5,8.9 \mathrm{~Hz}, 1 \mathrm{H}, \mathrm{OCH}_{2}\right), 4.54-4.34\left(\mathrm{~m}, 5 \mathrm{H}, \mathrm{CH}_{2}+\mathrm{CO}_{2} \mathrm{CH}_{2}\right), 3.92$ - $3.74\left(\mathrm{~m}, 2 \mathrm{H}, \mathrm{CH}_{2}\right), 3.55\left(\mathrm{t}, J=6.5 \mathrm{~Hz}, 2 \mathrm{H}, \mathrm{CH}_{2} \mathrm{Br}\right), 2.33$ (papp, J=6.3 Hz, 2H, CH $\left.\mathrm{CH}_{2}-\mathrm{CH}_{2} \mathrm{Br}\right) .{ }^{13} \mathrm{C}$ NMR (101 $\mathrm{MHz}$, Chloroform-d) $\delta$ 165.9, 165.6, 157.9, 141.5, 134.1, 133.2, 131.9, 131.3, 130.3, 129.6, 128.2, 126.3, 94.3, 86.5, 84.0, 63.6, 63.0, 62.4, 46.2, 41.3, 31.7, 29.3. IR $\left(\nu_{\max ,} \mathrm{cm}^{-1}\right) 2987$ (s), 2972 (s), 2920 (s), 2900 (s), 1749 (s), 1715 (s), 1480 (s), 1407 (s), 1382 (s), 1268 (s), 1249 (s), 1104 (s), 1045 (s), 1017 (s). HRMS (nanochip-ESI/LTQ-Orbitrap) m/z: [M + Na] ${ }^{+}$Calcd for $\mathrm{C}_{24} \mathrm{H}_{21}{ }^{79} \mathrm{BrINNaO}_{6}{ }^{+}$647.9489; Found 647.9478.

4-(4-((Allyloxy)carbonyl)phenyl)-2-(2-oxooxazolidin-3-yl)but-3-yn-1-yl iodobenzoate (12h)<smiles>C=CCOC(=O)c1cccc(C#CC(COC(=O)c2ccccc2I)N2CCOC2=O)c1</smiles>

Obtained from $N$-vinyloxazolidin-2-one $(\mathbf{1 a}, 0.042 \mathrm{~g}, 0.37 \mathrm{mmol}$, 1.5 equiv); $11 \mathrm{~g}$ ( $0.108 \mathrm{~g}, 0.250 \mathrm{mmol}, 1.0$ equiv); $\operatorname{BIOAc}(\mathbf{7}, 0.038 \mathrm{~g}$, $0.15 \mathrm{mmol}, 0.5$ equiv) and $4-\mathrm{ClCZIPN}(\mathbf{4 b}, 5 \mathrm{mg}, 5 \mu \mathrm{mol}, 2 \mathrm{~mol} \%)$ after 18 hours.

Column: Pentane:EtOAc, 8:2 to 5:5. Yield $37 \%(0.047 \mathrm{~g}, 0.093 \mathrm{mmol})$. Clear oil.

Rf (pentane:EtOAc 8:2) $=0.15$.

${ }^{1} \mathbf{H}$ NMR $(400 \mathrm{MHz}$, Chloroform-d) $\delta 8.13(\mathrm{td}, J=1.7,0.6 \mathrm{~Hz}, 1 \mathrm{H}, \operatorname{Ar} H), 8.09-8.03(\mathrm{~m}, 1 \mathrm{H}, \operatorname{Ar} H), 8.00$ $(\mathrm{dd}, J=7.9,1.2 \mathrm{~Hz}, 1 \mathrm{H}, \mathrm{ArH}), 7.84(\mathrm{dd}, J=7.8,1.7 \mathrm{~Hz}, 1 \mathrm{H}, \mathrm{ArH}), 7.63(\mathrm{dt}, J=7.7,1.4 \mathrm{~Hz}, 1 \mathrm{H}, \operatorname{ArH}), 7.43$ $(\operatorname{tdd}, J=7.7,2.7,0.9 \mathrm{~Hz}, 2 \mathrm{H}, \mathrm{ArH}), 7.18(\mathrm{ddd}, J=8.0,7.4,1.7 \mathrm{~Hz}, 1 \mathrm{H}, \mathrm{ArH}), 6.05(\mathrm{ddt}, J=17.2,10.4,5.7$ $\left.\mathrm{Hz}, 1 \mathrm{H}, \mathrm{CH}=\mathrm{CH}_{2}\right), 5.45(\mathrm{q}, J=1.5 \mathrm{~Hz}, 1 \mathrm{H}, \mathrm{NCH}), 5.38\left(\mathrm{~d}, J=4.4 \mathrm{~Hz}, 1 \mathrm{H}, \mathrm{CH}=\mathrm{CH}_{2}\right), 5.33(\mathrm{q}, J=1.3 \mathrm{~Hz}$, $\left.1 \mathrm{H}, \mathrm{CH}_{2}-\mathrm{CH}=\mathrm{CH}_{2}\right), 4.84\left(\mathrm{dt}, J=5.7,1.4 \mathrm{~Hz}, 2 \mathrm{H}, \mathrm{CH}=\mathrm{CH}_{2}\right), 4.78\left(\mathrm{dd}, J=11.5,8.9 \mathrm{~Hz}, 1 \mathrm{H}, \mathrm{CH}_{2}\right), 4.53-$ $4.33\left(\mathrm{~m}, 3 \mathrm{H}, \mathrm{CH}_{2}\right), 3.91-3.74\left(\mathrm{~m}, 2 \mathrm{H}, \mathrm{CH}_{2}\right) .{ }^{13} \mathrm{C}$ NMR $(101 \mathrm{MHz}$, Chloroform-d) $\delta 165.9,165.3,157.9$, $141.4,136.1,134.1,133.1,133.1,131.9,131.3,130.6,130.2,128.7,128.2,122.0,118.7,94.3,86.3,81.9$, 66.0, 63.7, 62.4, 46.2, 41.3. IR $\left(v_{\max } \mathrm{cm}^{-1}\right) 3004$ (s), 2986 (s), 2972 (s), 2911 (s), 2900 (s), 2883 (s), 1732 (s), $1487(\mathrm{~s}), 1419(\mathrm{~s}), 1376(\mathrm{~s}), 1285(\mathrm{~s}), 1242(\mathrm{~s}), 1226(\mathrm{~s}), 1133(\mathrm{~s}), 1101(\mathrm{~s}), 1080(\mathrm{~s}), 1038(\mathrm{~s}), 1028$ (s). HRMS (nanochip-ESI/LTQ-Orbitrap) $\mathrm{m} / \mathrm{z}$ : $[\mathrm{M}+\mathrm{Na}]^{+}$Calcd for $\mathrm{C}_{24} \mathrm{H}_{20} \mathrm{INNaO}{ }_{6}{ }^{+} 568.0228$; Found 568.0211. 
<smiles>CCCCOC(C#Cc1ccc(C(F)(F)F)cc1)COC(=O)c1ccccc1I</smiles>

Rf (pentane:EtOAc 9:1) $=0.55$

'H NMR $(400 \mathrm{MHz}$, Chloroform- $d$ ) $\delta 8.01(\mathrm{dd}, J=8.0,1.2 \mathrm{~Hz}, 1 \mathrm{H}, \mathrm{Ar} H), 7.88(\mathrm{dd}, J=7.8,1.7 \mathrm{~Hz}, 1 \mathrm{H}$, $\operatorname{ArH}), 7.67-7.47(\mathrm{~m}, 4 \mathrm{H}, \mathrm{ArH}), 7.40(\mathrm{td}, J=7.6,1.2 \mathrm{~Hz}, 1 \mathrm{H}, \mathrm{ArH}), 7.16(\mathrm{td}, J=7.7,1.7 \mathrm{~Hz}, 1 \mathrm{H}, \mathrm{ArH}), 4.69$ $(\mathrm{dd}, J=6.8,4.8 \mathrm{~Hz}, 1 \mathrm{H}, \mathrm{OCH}), 4.63-4.49(\mathrm{~m}, 2 \mathrm{H}, \mathrm{OCH}), 3.85\left(\mathrm{dt}, J=9.2,6.6 \mathrm{~Hz}, 1 \mathrm{H}, \mathrm{OCH}_{2}\right), 3.56(\mathrm{dt}$, $J=9.2,6.5 \mathrm{~Hz}, 1 \mathrm{H}, \mathrm{OCH})_{2}, 1.70-1.58\left(\mathrm{~m}, 2 \mathrm{H}, \mathrm{CH}_{2}-\mathrm{CH}_{2}-\mathrm{CH}_{3}\right), 1.55-1.33\left(\mathrm{~m}, 2 \mathrm{H}, \mathrm{CH}_{2}-\mathrm{CH}_{2}-\mathrm{CH}_{3}\right), 0.93$ $\left(\mathrm{t}, J=7.4 \mathrm{~Hz}, 3 \mathrm{H}, \mathrm{CH}_{2}-\mathrm{CH}_{2}-\mathrm{CH}_{3}\right) .{ }^{13} \mathrm{C}$ NMR $(101 \mathrm{MHz}$, Chloroform- $d) \delta$ 166.0, 141.5, 134.6, 132.9, 132.1, $131.3,130.4(q, J=33.0 \mathrm{~Hz}), 127.9,126.0,125.3(q, J=3.8 \mathrm{~Hz}), 123.8(\mathrm{q}, J=272.3 \mathrm{~Hz}), 94.3,87.4,85.5$, 69.4, 68.2, 66.5, 31.6, 19.3, 13.9. ${ }^{19}$ F NMR $\left(376 \mathrm{MHz}\right.$, Chloroform-d) $\delta$-62.9. IR $\left(\nu_{\max }, \mathrm{cm}^{-1}\right) 1732(\mathrm{~s})$, $1321(\mathrm{~s}), 1286(\mathrm{~s}), 1243(\mathrm{~s}), 1167$ (s), 1125 (s), $1104(\mathrm{~s}), 1092(\mathrm{~s}), 1086$ (s), 1066 (s), $1044(\mathrm{~s}), 1016$ (s). HRMS (ESI/QTOF) m/z: [M + Na] ${ }^{+}$Calcd for $\mathrm{C}_{22} \mathrm{H}_{20} \mathrm{~F}_{3} \mathrm{INaO}_{3}{ }^{+}$539.0301; Found 539.0306.

4-(4-((3-Bromopropoxy)carbonyl)phenyl)-2-butoxybut-3-yn-1-yl 2-iodobenzoate $(\mathbf{1 2 j})$<smiles>CCCCOC(C#Cc1ccc(C(=O)OCCCBr)cc1)COC(=O)c1ccccc1I</smiles>

Obtained from nbutyl vinyl ether $(9 \mathbf{a}, 0.048 \mathrm{~mL}, 0.38 \mathrm{mmol}, 1.5$ equiv); $11 \mathrm{f}(0.124 \mathrm{~g}, 0.250 \mathrm{mmol}, 1.0$ equiv); $\operatorname{BIOAc}(\mathbf{7}, 0.038 \mathrm{~g}, 0.15$ mmol, 0.5 equiv) and 4-ClCzIPN (4b, 5 mg, 5 umol, 2 mol\%) after 18 hours.

Column: Pentane:EtOAc, 98:2 to 90:10. Yield 52\% (0.079 g, 0.13 mmol). Yellow oil.

Rf (pentane:EtOAc 9:1) $=0.5$

${ }^{1}$ H NMR $(400 \mathrm{MHz}$, Chloroform-d $) \delta 7.96-7.87(\mathrm{~m}, 3 \mathrm{H}, \mathrm{ArH}), 7.80(\mathrm{dd}, J=7.8,1.7 \mathrm{~Hz}, 1 \mathrm{H}, \mathrm{ArH}), 7.49$ $-7.40(\mathrm{~m}, 2 \mathrm{H}, \mathrm{ArH}), 7.33(\mathrm{td}, J=7.6,1.2 \mathrm{~Hz}, 1 \mathrm{H}, \mathrm{ArH}), 7.09(\mathrm{td}, J=7.7,1.7 \mathrm{~Hz}, 1 \mathrm{H}, \operatorname{ArH}), 4.62(\mathrm{dd}, J=$ $6.7,4.8 \mathrm{~Hz}, 1 \mathrm{H}, \mathrm{OCH}), 4.57-4.47\left(\mathrm{~m}, 2 \mathrm{H}, \mathrm{CH}_{2}\right), 4.40\left(\mathrm{t}, J=6.0 \mathrm{~Hz}, 2 \mathrm{H}, \mathrm{CH}_{2}\right), 3.78(\mathrm{dt}, J=9.2,6.6 \mathrm{~Hz}, 1 \mathrm{H}$, $\left.\mathrm{CH}_{2}\right), 3.48\left(\mathrm{dt}, J=9.8,6.5 \mathrm{~Hz}, 3 \mathrm{H}, \mathrm{CH}_{2}\right), 2.25\left(\mathrm{p}_{\mathrm{app},} J=6.3 \mathrm{~Hz}, 2 \mathrm{H}, \mathrm{CH}_{2}-\mathrm{CH}_{2} \mathrm{Br}\right), 1.65-1.49\left(\mathrm{~m}, 2 \mathrm{H}, \mathrm{CH}_{2^{-}}\right.$ $\left.\mathrm{CH}_{2}-\mathrm{CH}_{3}\right), 1.49-1.28\left(\mathrm{~m}, 2 \mathrm{H}, \mathrm{CH}_{2}-\mathrm{CH}_{2}-\mathrm{CH}_{3}\right), 0.85\left(\mathrm{t}, J=7.4 \mathrm{~Hz}, 2 \mathrm{H}, \mathrm{CH}_{2}-\mathrm{CH}_{2}-\mathrm{CH}_{3}\right) .{ }^{13} \mathrm{C} \mathrm{NMR}(101 \mathrm{MHz}$, Chloroform-d) $\delta$ 166.0, 165.7, 141.4, 134.6, 132.9, 131.8, 131.3, 129.8, 129.5, 129.4, 127.9, 127.1, 94.3, 88.0, 86.1, 69.4, 68.2, 66.5, 62.9, 31.8, 31.6, 29.4, 19.3, 13.9. IR $\left(v_{\left.\max , \mathrm{cm}^{-1}\right)} 2997\right.$ (s), 2987 (s), 2977 (s), $2971(\mathrm{~s}), 2901(\mathrm{~s}), 2892(\mathrm{~s}), 1732(\mathrm{~m}), 1394(\mathrm{~m}), 1266(\mathrm{~s}), 1242(\mathrm{~s}), 1088(\mathrm{~s}), 1066$ (s), 1040 (s). HRMS (ESI/QTOF) $\mathrm{m} / \mathrm{z}:[\mathrm{M}+\mathrm{Na}]^{+}$Calcd for $\mathrm{C}_{25} \mathrm{H}_{26} \mathrm{BrINaO}_{5}{ }^{+}$634.9901; Found 634.9907 


\section{Gram scale synthesis and product modification}

Sunlight experiment

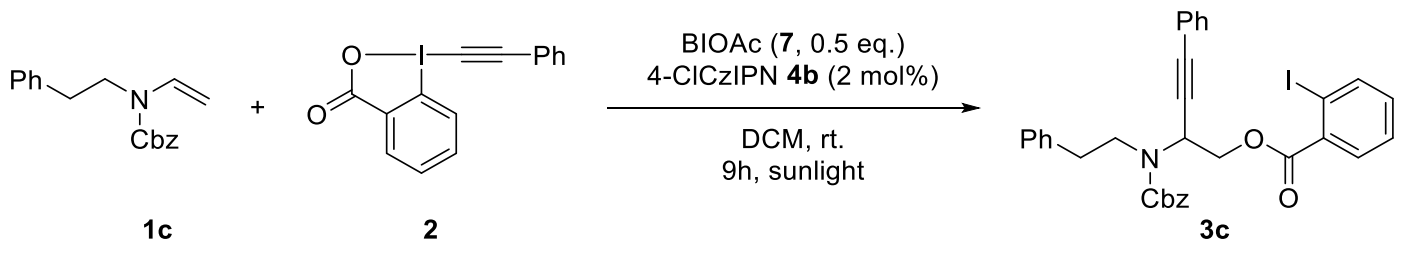

An oven-dried flat-bottomed $2 \mathrm{~mL}$ screw-cap vial equipped with a magnetic stirrer was charged with Ph-EBX (2, $0.087 \mathrm{~g}, 0.25 \mathrm{mmol}, 1.0$ equiv), $\operatorname{BIOAC}(\mathbf{7}, 0.038 \mathrm{~g}, 0.13 \mathrm{mmol}, 0.5$ equiv) and 4-CICzIPN (4b, $5 \mathrm{mg}, 5 \mu \mathrm{mol}, 2 \mathrm{~mol} \%$ ). The reaction vessel was sealed with a rubber septum. Following three vacuum/nitrogen cycles, the vial was refilled with argon. Then, dry, degassed (via freeze-pump-thaw technique) $\mathrm{CH}_{2} \mathrm{Cl}_{2}(10.0 \mathrm{~mL}, 0.29 \mathrm{M})$ was added. Benzyl phenethyl(vinyl) carbamate (1c, $0.106 \mathrm{~g}, 0.375 \mathrm{mmol}, 1.5$ equiv) was then added via syringe. The reaction was placed in direct sunlight for $5 \mathrm{~h}$ under stirring then $4 \mathrm{~h}$ without stirring. $\mathrm{A}$ deactivated solid deposit for flash chromatography was prepared: a slurry of $\mathrm{SiO}_{2}$ (ca. $3 \mathrm{~g}$ ) and ca. $0.2 \mathrm{~mL}$ of $\mathrm{Et}_{3} \mathrm{~N}$ was prepared and then combined with the crude reaction mixture before concentration. The crude was then purified though flash chromatography (biotage: $\mathrm{SiO}_{2} 25 \mathrm{~g}$, Pentane:EtOAc $0 \%$ to $15 \%)$ affording $3 \mathrm{c}(0.107 \mathrm{~g}, 0.170 \mathrm{mmol}, 68 \%$ yield $)$.

Weather report: ${ }^{32}$ sunny with partial clouds temperature from $23-30{ }^{\circ} \mathrm{C}$.

Gram scale<smiles>C=CN1CCCC1=O</smiles>

$1 \mathrm{i}$<smiles>O=C1OI(C#Cc2ccccc2)c2ccccc21</smiles>

2

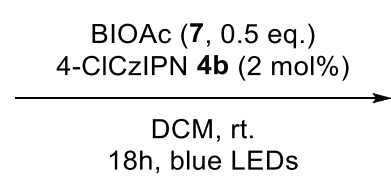

$18 \mathrm{~h}$, blue LEDs

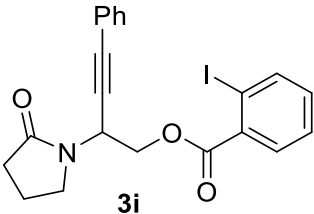

$3 \mathbf{i}$

An oven-dried flat-bottomed $10 \mathrm{~mL}$ snap-cap vial equipped with a magnetic stirrer was charged with Ph-EBX (2, $1.00 \mathrm{~g}, 2.87 \mathrm{mmol}, 1.0$ equiv), BIOAc (7, $0.440 \mathrm{~g}, 2.87 \mathrm{mmol}, 0.5$ equiv) and 4-CICzIPN (4b, $61 \mathrm{mg}, 57 \mu \mathrm{mol}, 2$ mol\%). The reaction vessel was sealed with a rubber septum. Following three vacuum/nitrogen cycles, the vial was refilled with argon. Then, dry, degassed (via freeze-pump-thaw technique) $\mathrm{CH}_{2} \mathrm{Cl}_{2}(10.0 \mathrm{~mL}, 0.29 \mathrm{M})$ was added. $N$-vinyl pyrrolidinone (1ii, $0.46 \mathrm{~mL}, 4.3 \mathrm{mmol}, 1.5$ equiv) was then added via syringe. The reaction was irradiated overnight ( $18 \mathrm{~h}$ ) with blue LED strips under ventilation $\left(\mathrm{T}=\mathrm{ca} .25^{\circ} \mathrm{C}\right)$ and stirring. $\mathrm{A}$ deactivated solid deposit for flash chromatography was prepared: a slurry of $\mathrm{SiO}_{2}$ (ca. $20 \mathrm{~g}$ ) and ca. $1 \mathrm{~mL}$ of $\mathrm{Et}_{3} \mathrm{~N}$ was prepared and then combined with the crude reaction mixture before concentration. The crude was then purified though flash chromatography (biotage : $\mathrm{SiO}_{2} 120$ g, Pentane:EtOAc 20\% to 50\%) affording 3i (0.998 g, $1.83 \mathrm{mmol}, 64 \%$ yield).

${ }^{32}$ https://www.historique-meteo.net/europe/suisse/lausanne/2019/07/24/ consulted on the 02.06.2020 
1-(1-Hydroxy-4-phenylbut-3-yn-2-yl)pyrrolidin-2-one (13)<smiles>O=C(OCC(C#Cc1ccccc1)N1CCCC1=O)c1ccccc1I</smiles>

$3 \mathbf{i}$<smiles>O=C1CCCN1C(C#CPc1ccccc1)CO</smiles>

13

Following a modified reported procedure, ${ }^{33}$ a flame dried $5 \mathrm{~mL}$ microwave vial with a rubber septum and magnetic stirring bar was charged with $\mathbf{3 i}$ (100.0 mg, $217.0 \mu \mathrm{mol}, 1.00$ equiv), potassium;carbonate $(0.045 \mathrm{mg}, 0.32 \mathrm{mmol}, 1.50$ equiv) and ethanol $(2 \mathrm{~mL})$. The vial was sealed and stirred at reflux for $2 \mathrm{~h}$. At this time TLC showed full conversion of the starting material. The solvent was evaporated on top a silica plug then submitted to flash chromatography (Biotage $\mathrm{SiO}_{2} 12$ g: $\mathrm{CH}_{2} \mathrm{Cl}_{2}: \mathrm{AcOEt}: \mathrm{MeOH}$ 80:20:0, 60:40:0, 80:0:20) to afford 1-(1-hydroxy-4phenylbut-3-yn-2-yl)pyrrolidin-2-one $(\mathbf{1 3}, 0.048 \mathrm{~g}, 0.21 \mathrm{mmol}, 96 \%$ yield) as a yellowish oil.

Rf $\left(\mathrm{CH}_{2} \mathrm{Cl}_{2}: \mathrm{MeOH} 8: 2\right)=0.3$.

${ }^{1} \mathbf{H}$ NMR (400 MHz, Chloroform-d) $\delta 7.45(\mathrm{dd}, J=7.4,2.1 \mathrm{~Hz}, 2 \mathrm{H}, \operatorname{ArH}), 7.34(\mathrm{td}, J=4.8,2.3 \mathrm{~Hz}$, $3 \mathrm{H}, \mathrm{ArH}), 5.27(\mathrm{dd}, J=8.1,4.8 \mathrm{~Hz}, 1 \mathrm{H}, \mathrm{N}-\mathrm{CHR} 2), 3.92\left(\mathrm{dd}, J=11.4,4.7 \mathrm{~Hz}, 1 \mathrm{H}, \mathrm{O}-\mathrm{CH}_{2} \mathrm{R}\right), 3.82$ $\left(\mathrm{dd}, J=11.4,8.1 \mathrm{~Hz}, 1 \mathrm{H}, \mathrm{O}-\mathrm{CH}_{2} \mathrm{R}\right), 3.74-3.65\left(\mathrm{~m}, 1 \mathrm{H}\right.$, cyclic- $\left.\mathrm{CH}_{2}-\mathrm{N}\right), 3.60(\mathrm{dt}, J=9.5,7.0 \mathrm{~Hz}$, $1 \mathrm{H}$, cyclic- $\left.\mathrm{CH}_{2}-\mathrm{N}\right), 3.05$ (bs, 1H, OH), $2.54-2.44(\mathrm{~m}, 2 \mathrm{H}$, cyclic-CO-CH $), 2.17-2.05(\mathrm{~m}, 2 \mathrm{H}$, cyclic- $\left.\mathrm{CH}_{2}\right) .{ }^{13} \mathrm{C}$ NMR $(101 \mathrm{MHz}$, Chloroform-d) $\delta 175.8,131.9,128.7,128.4,122.1,86.0,83.0$, 63.7, 47.0, 44.4, 31.3, 17.9. IR $\left(v_{\max } \mathrm{cm}^{-1}\right) 3373(\mathrm{w}), 2938(\mathrm{w}), 2879(\mathrm{w}), 1662(\mathrm{~s}), 1420(\mathrm{~m}), 1287$ (m), 1069 (m). HRMS (ESI/QTOF) m/z: [M + Na] ${ }^{+}$Calcd for $\mathrm{C}_{14} \mathrm{H}_{15} \mathrm{NNaO}_{2}{ }^{+} 252.0995$; Found 252.1001.

2-Butoxy-4-phenylbut-3-yn-1-ol (14)
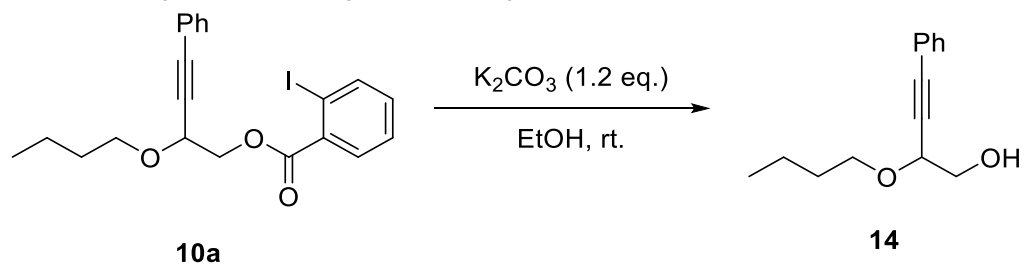

Following a slightly modified reported procedure, ${ }^{33}$ a flame dried $5 \mathrm{~mL}$ microwave vial with a rubber septum and magnetic stirring bar was charged with 10a $(26.0 \mathrm{mg}, 58.0 \mu \mathrm{mol}, 1.00$ equiv), potassium;carbonate (9.62 mg, $69.6 \mu \mathrm{mol}, 1.20$ equiv) and ethanol $(600 \mu \mathrm{L})$. The mixture was stirred at room temperature for $60 \mathrm{~h}$, then the solvent was evaporated and submitted to flash chromatography $\left(\mathrm{SiO}_{2}, \mathrm{CH}_{2} \mathrm{Cl}_{2}\right.$ : EtOAc) to afford (14, $11.5 \mathrm{mg}, 52.7 \mathrm{mmol}, 91 \%$ yield).

$\boldsymbol{R f}\left(\mathrm{CH}_{2} \mathrm{Cl}_{2}\right)=0.3$.

${ }^{1} \mathbf{H}$ NMR (400 MHz, Chloroform-d) $\delta 7.48-7.41(\mathrm{~m}, 2 \mathrm{H}, \mathrm{PhH}), 7.36-7.27(\mathrm{~m}, 3 \mathrm{H}, \mathrm{PhH}), 4.36$ $(\mathrm{dd}, J=6.2,5.5 \mathrm{~Hz}, 1 \mathrm{H}, \mathrm{OCH}), 3.87(\mathrm{dt}, J=9.3,6.6 \mathrm{~Hz}, 1 \mathrm{H}, \mathrm{OCH}), 3.80\left(\mathrm{t}, J=5.1 \mathrm{~Hz}, 2 \mathrm{H}, \mathrm{OCH}_{2}\right)$, $3.51(\mathrm{dt}, J=9.2,6.6 \mathrm{~Hz}, 1 \mathrm{H}, \mathrm{OCH})_{2}, 2.26(\mathrm{~d}, J=18.6 \mathrm{~Hz}, 1 \mathrm{H}, \mathrm{OH}), 1.70-1.58\left(\mathrm{~m}, 2 \mathrm{H}, \mathrm{CH}_{2}-\mathrm{CH}_{2}-\right.$

\footnotetext{
${ }^{33}$ Hari, D. P. and Waser, J. J. Am. Chem. Soc. 2016, 138, 2190
} 
$\left.\mathrm{CH}_{3}\right), 1.49-1.35\left(\mathrm{~m}, 2 \mathrm{H}, \mathrm{CH}_{2}-\mathrm{CH}_{2}-\mathrm{CH}_{3}\right), 0.95\left(\mathrm{t}, J=7.4 \mathrm{~Hz}, 3 \mathrm{H}, \mathrm{CH}_{2}-\mathrm{CH}_{2}-\mathrm{CH}_{3}\right) .{ }^{13} \mathrm{C}$ NMR (101 $\mathrm{MHz}$, Chloroform-d) $\delta 131.8,128.6,128.3,122.3,86.8,85.2,70.9,69.3,65.4,31.7,19.3,13.9$. IR $\left(v_{\max } \mathrm{cm}^{-1}\right) 3426(\mathrm{~m}), 3006(\mathrm{~s}), 2987(\mathrm{~s}), 2958(\mathrm{~s}), 2892(\mathrm{~s}), 2867(\mathrm{~s}), 1382(\mathrm{~m}), 1103(\mathrm{~s}), 1066(\mathrm{~s})$, 1047 (s). HRMS (ESI/QTOF) m/z: [M + Na] ${ }^{+}$Calcd for $\mathrm{C}_{14} \mathrm{H}_{18} \mathrm{NaO}_{2}{ }^{+} 241.1199 ;$ Found 241.1195.

2-(Phenethylamino)-4-phenylbut-3-yn-1-yl 2-iodobenzoate (15)<smiles>O=C(OCC(C#Cc1ccccc1)N(CCc1ccccc1)C(=O)OCc1ccccc1)c1ccccc1I</smiles>

$3 b$

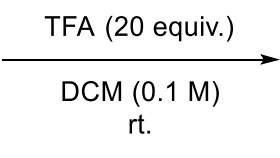<smiles>O=C(OCC(C#Cc1ccccc1)NCCc1ccccc1)c1ccccc1I</smiles>

15

To a $5 \mathrm{~mL}$ vial equipped with a magnetic stirrer, $3 \mathbf{b}(0.047 \mathrm{~g}, 0.078 \mathrm{mmol}$, 1 equiv) were dissolved in $\mathrm{CH}_{2} \mathrm{Cl}_{2}(0.8 \mathrm{~mL})$, trifluoroacetic acid $(130 \mu \mathrm{L}, 1.90 \mathrm{mmol}, 25$ equiv) was added dropwise at room temperature. The reaction was stirred for $1 \mathrm{~h} 30 \mathrm{~min}$. At this time, TLC showed full conversion of $\mathbf{3} \mathbf{b}$. TFA and $\mathrm{CH}_{2} \mathrm{Cl}_{2}$ were evaporated off. The crude was diluted with $\mathrm{Et}_{2} \mathrm{O}$ (1 $\mathrm{mL}$ ) and basified with $\mathrm{Na}_{2} \mathrm{CO}_{3}$ aq. sat. $(0.5 \mathrm{~mL})$ until $\mathrm{ph}>11$. The aqueous layer was extracted a second time with $\mathrm{Et}_{2} \mathrm{O}(1.5 \mathrm{~mL})$. The combined organic layers were combined, dried over $\mathrm{MgSO}_{4}$, then passed through a short plug of deactivated silica. The plug was then washed through with EtOAc. Upon concentration pure 15 was obtained as a colorless oil $(0.029 \mathrm{~g}$, $0.059,74 \%$ yield).

Rf $\left(\mathrm{CH}_{2} \mathrm{Cl}_{2}\right)=0.15$.

${ }^{1} \mathbf{H}$ NMR $\left(400 \mathrm{MHz}\right.$, Acetonitrile- $\left.d_{3}\right) \delta 8.02(\mathrm{dd}, J=8.0,1.1 \mathrm{~Hz}, 1 \mathrm{H}, \operatorname{ArH}), 7.74(\mathrm{dd}, J=7.7,1.7$ $\mathrm{Hz}, 1 \mathrm{H}, \mathrm{ArH}), 7.47(\mathrm{td}, J=7.6,1.2 \mathrm{~Hz}, 1 \mathrm{H}, \mathrm{ArH}), 7.43-7.36(\mathrm{~m}, 2 \mathrm{H}, \mathrm{PhH}), 7.39-7.30(\mathrm{~m}, 3 \mathrm{H}$, $\mathrm{PhH}), 7.30-7.21(\mathrm{~m}, 5 \mathrm{H}, \mathrm{PhH}), 7.24-7.10(\mathrm{~m}, 1 \mathrm{H}, \mathrm{ArH}), 4.68-4.31\left(\mathrm{~m}, 2 \mathrm{H}, \mathrm{O}-\mathrm{CH}_{2}\right), 4.16-3.99$ (m, 1H, N-CHR), $3.17\left(\mathrm{dt}, J=11.2,7.2 \mathrm{~Hz}, 1 \mathrm{H}, \mathrm{N}-\mathrm{CH}_{2} \mathrm{R}\right), 2.96$ (ddd $J=11.3,7.6,6.1 \mathrm{~Hz}, 1 \mathrm{H}, \mathrm{N}-$ $\left.\mathrm{CH}_{2} \mathrm{R}\right), 2.91-2.67\left(\mathrm{~m}, 2 \mathrm{H}, \mathrm{Ph}-\mathrm{CH}_{2} \mathrm{R}\right), 2.26-2.00(\mathrm{~m}, 1 \mathrm{H}, \mathrm{R} 2 \mathrm{NH}) .{ }^{13} \mathrm{C}$ NMR $(101 \mathrm{MHz}$, Acetonitrile$\left.d_{3}\right) \delta 166.8,141.7,141.0,136.2,133.5,132.1,131.4,129.3,129.1,129.0,128.9,128.9,126.6$, 123.3, 93.7, 88.3, 84.7, 67.4, 50.0, 48.9, 36.5. IR $\left(v_{\max } \mathrm{cm}^{-1}\right) 3312(\mathrm{w}), 3060(\mathrm{w}), 3025$ (w), 2955 $(\mathrm{m}), 2899(\mathrm{~m}), 2847(\mathrm{w}), 1949(\mathrm{w}), 1730(\mathrm{~s}), 1583(\mathrm{~m}), 1490(\mathrm{~m}), 1442(\mathrm{~m}), 1285(\mathrm{~s}), 1247(\mathrm{~s})$, 1132 (s), 1099 (s), 1015 (s). HRMS (ESI/QTOF) m/z: $[\mathrm{M}+\mathrm{H}]^{+}$Calcd for $\mathrm{C}_{25} \mathrm{H}_{23} \mathrm{INO}_{2}{ }^{+} 496.0768$; Found 496.0769 . 
NMR spectra for synthesised alkenes and new compounds

Starting materials

1-[(4-(3-bromoprop-1-yl-benzoate)ethynyl]-1,2-benziodoxol-3(1H)-one (11 g)

${ }^{1} \mathrm{H}$ NMR $(400 \mathrm{MHz}$, Chloroform- $d$ )

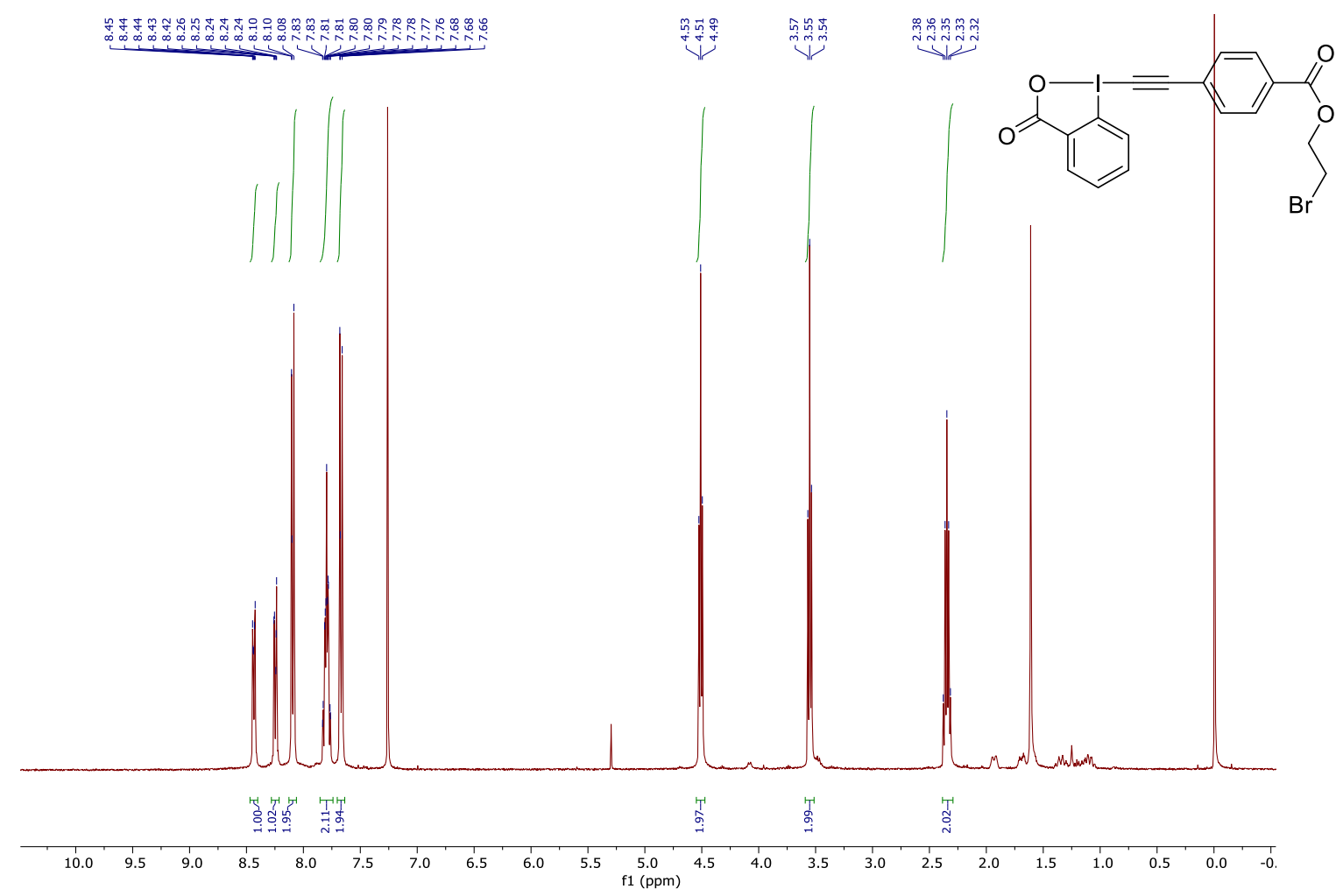

${ }^{13} \mathrm{C}$ NMR $(101 \mathrm{MHz}$, Chloroform- $d$ )

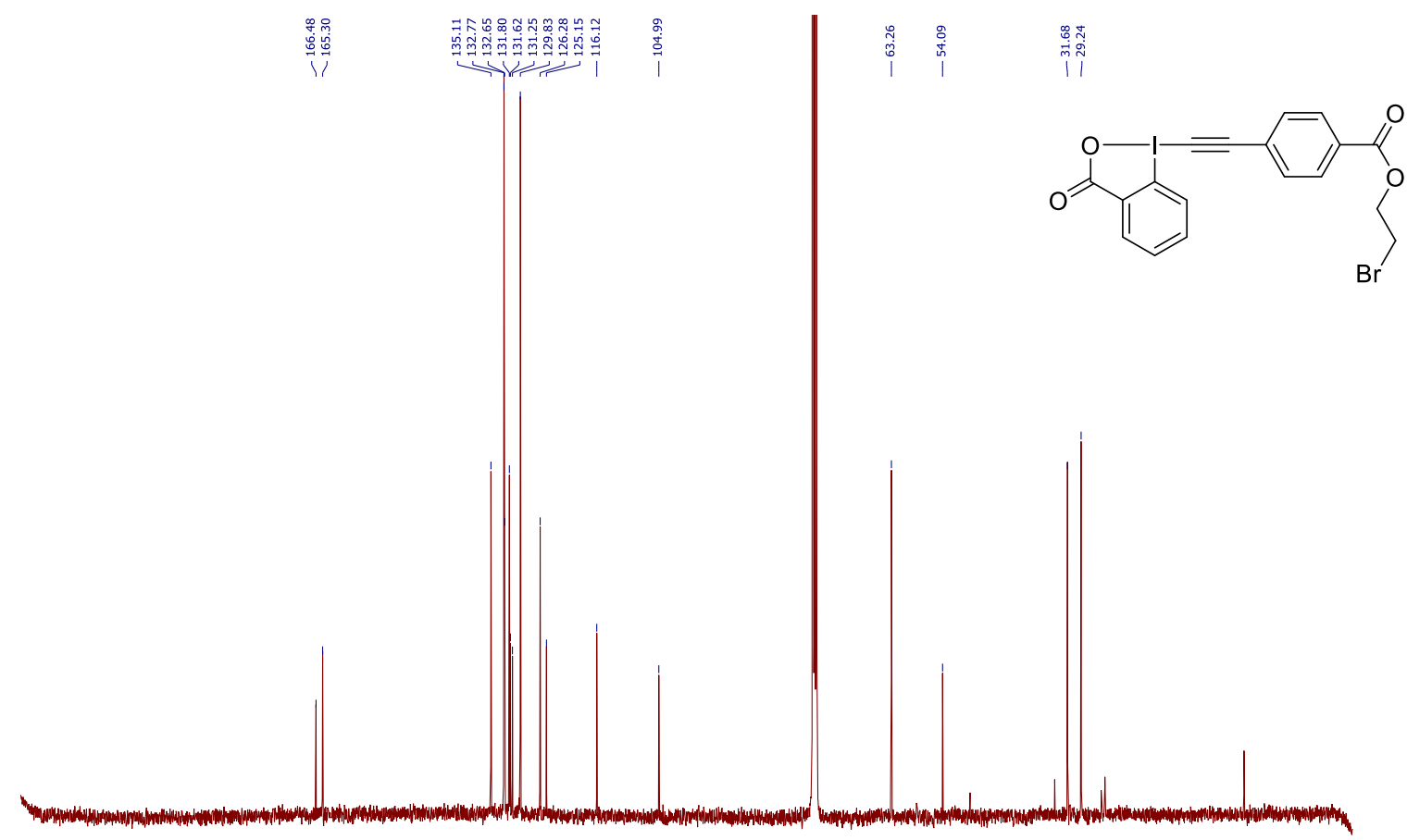

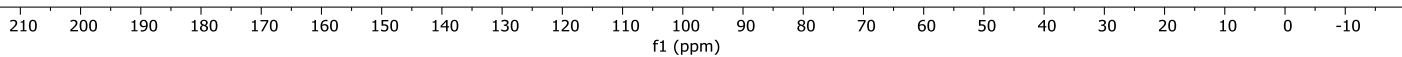


1-[(3-(prop-2-en-1-yl-benzoate)ethynyl]-1,2-benziodoxol-3(1H)-one (11 h) ${ }^{1} \mathrm{H}$ NMR $(400 \mathrm{MHz}$, Chloroform- $d$ )

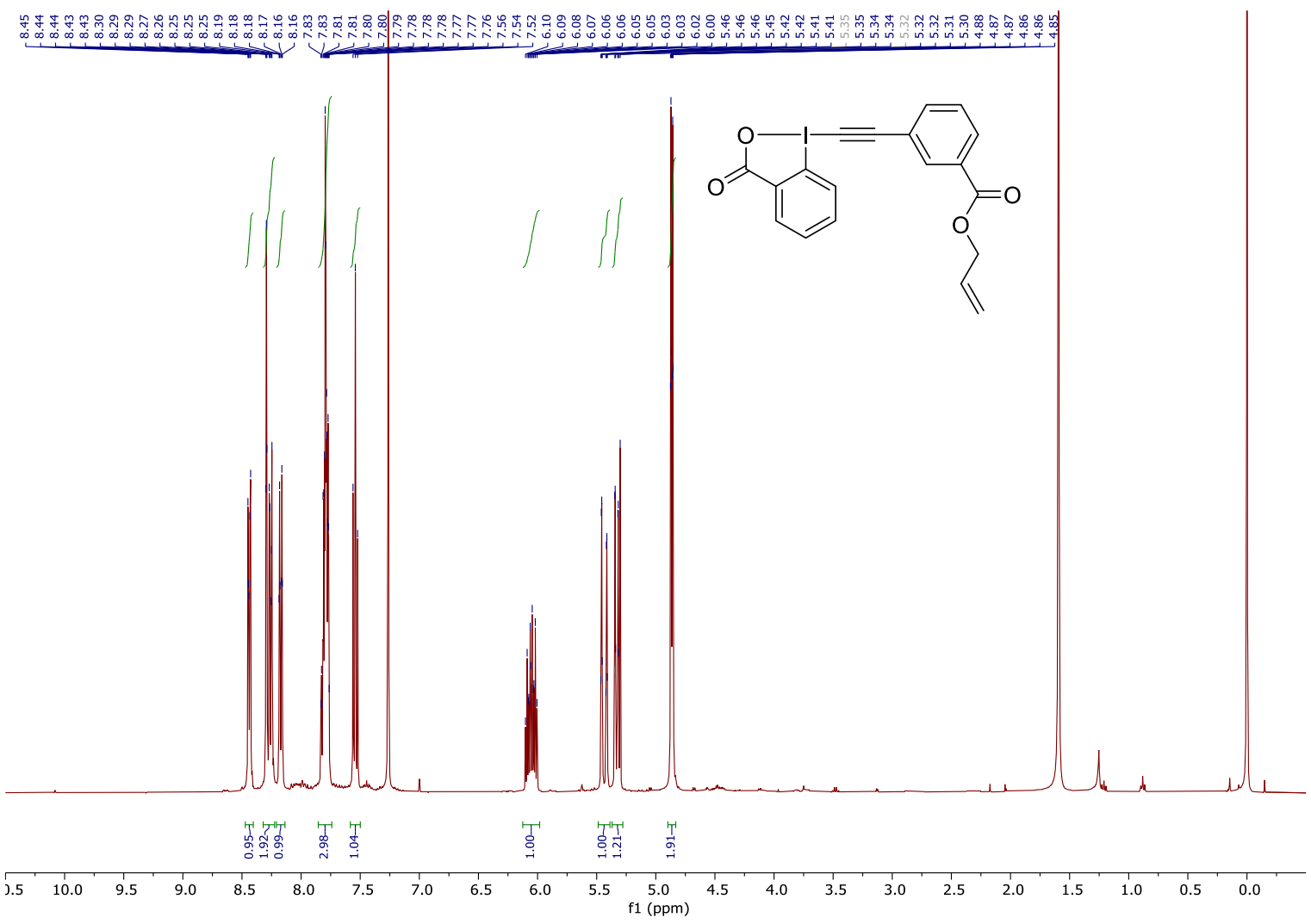

${ }^{13} \mathrm{C}$ NMR (101 MHz, Chloroform-d)

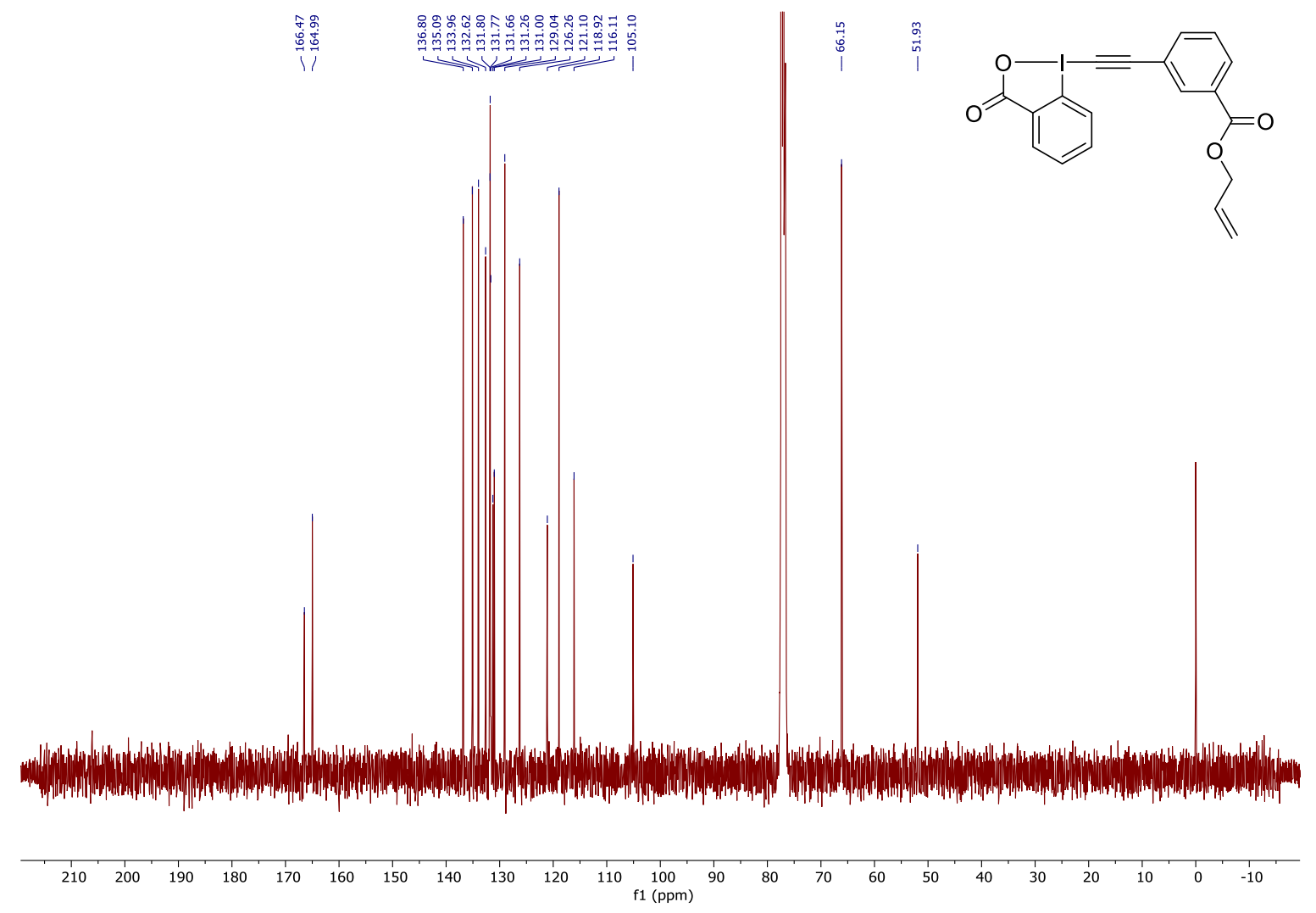


$\mathrm{N}$-vinyloxazolidin-2-one (1a)

${ }^{1} \mathrm{H}$ NMR (400 MHz, Chloroform-d)

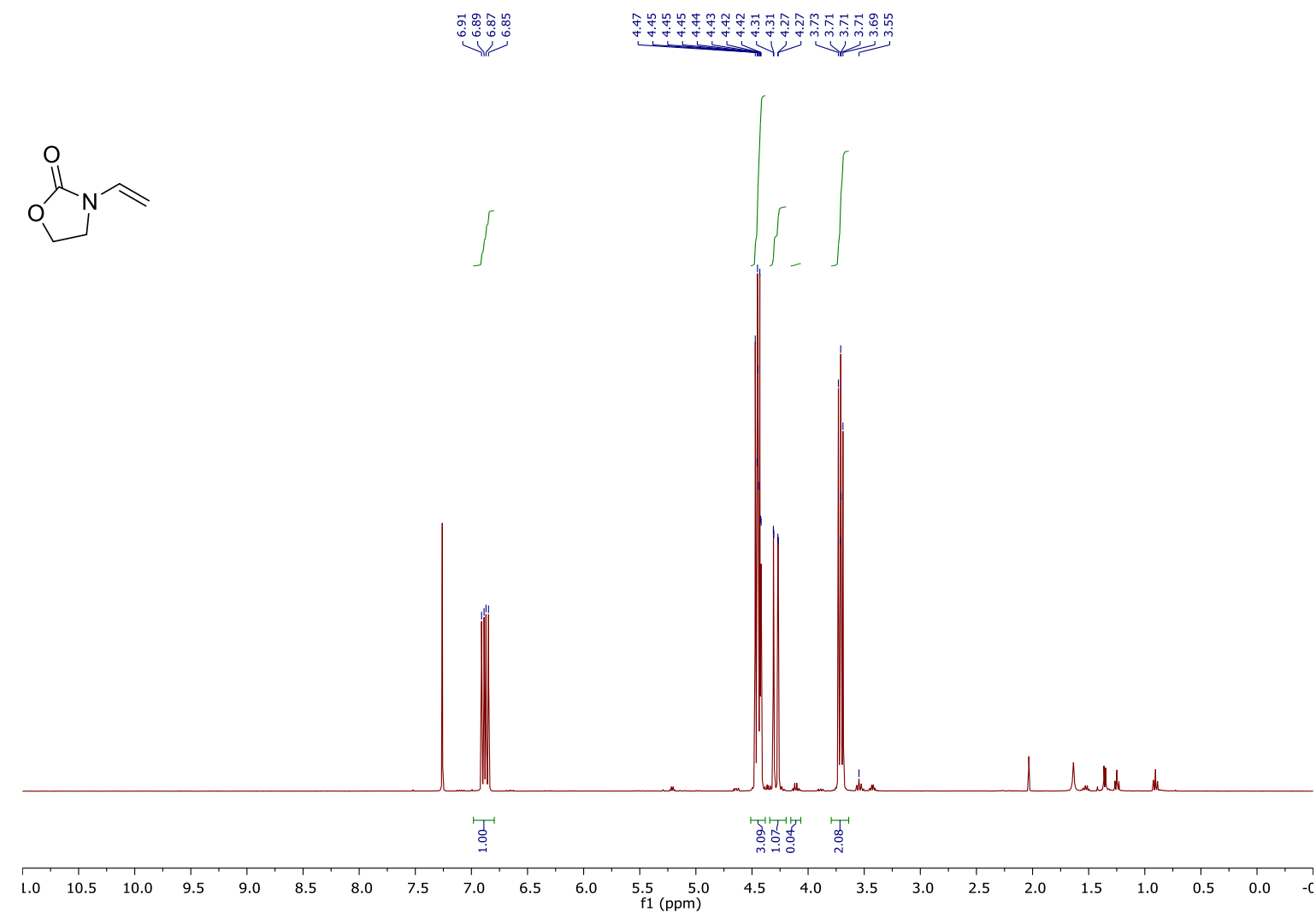


tert-butyl phenethyl(vinyl)carbamate (1 b)

${ }^{1} \mathrm{H}$ NMR (400 MHz, Chloroform-d)

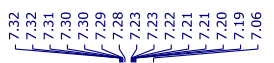

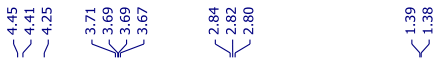

$\overbrace{\substack{1 \\ \text { Boc }}}^{\text {Ph }}$

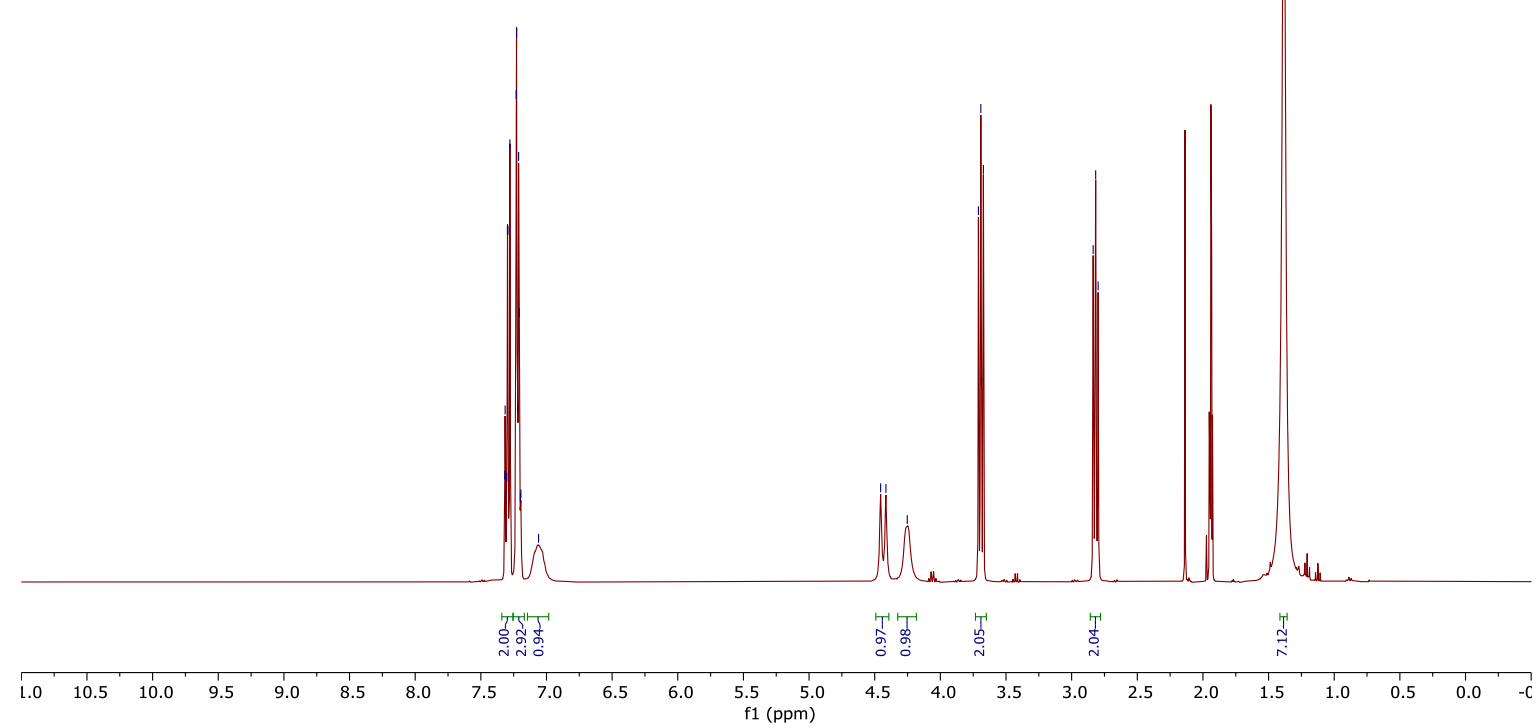

${ }^{13} \mathrm{C}$ NMR (101 MHz, Chloroform-d)
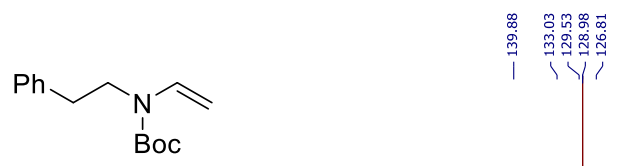

ণั

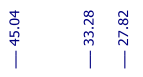

Boc

$20 \quad 210 \quad 200 \quad 190 \quad 180$

$170 \quad 160$

$150 \quad 140$

$\begin{array}{lllll}130 & 120 & 110 & 100 \\ & & & 100\end{array}$ 
Benzyl phenethyl(vinyl)carbamate (1c)

${ }^{1} \mathrm{H}$ NMR (400 MHz, Acetonitrile- $d_{3}$ )

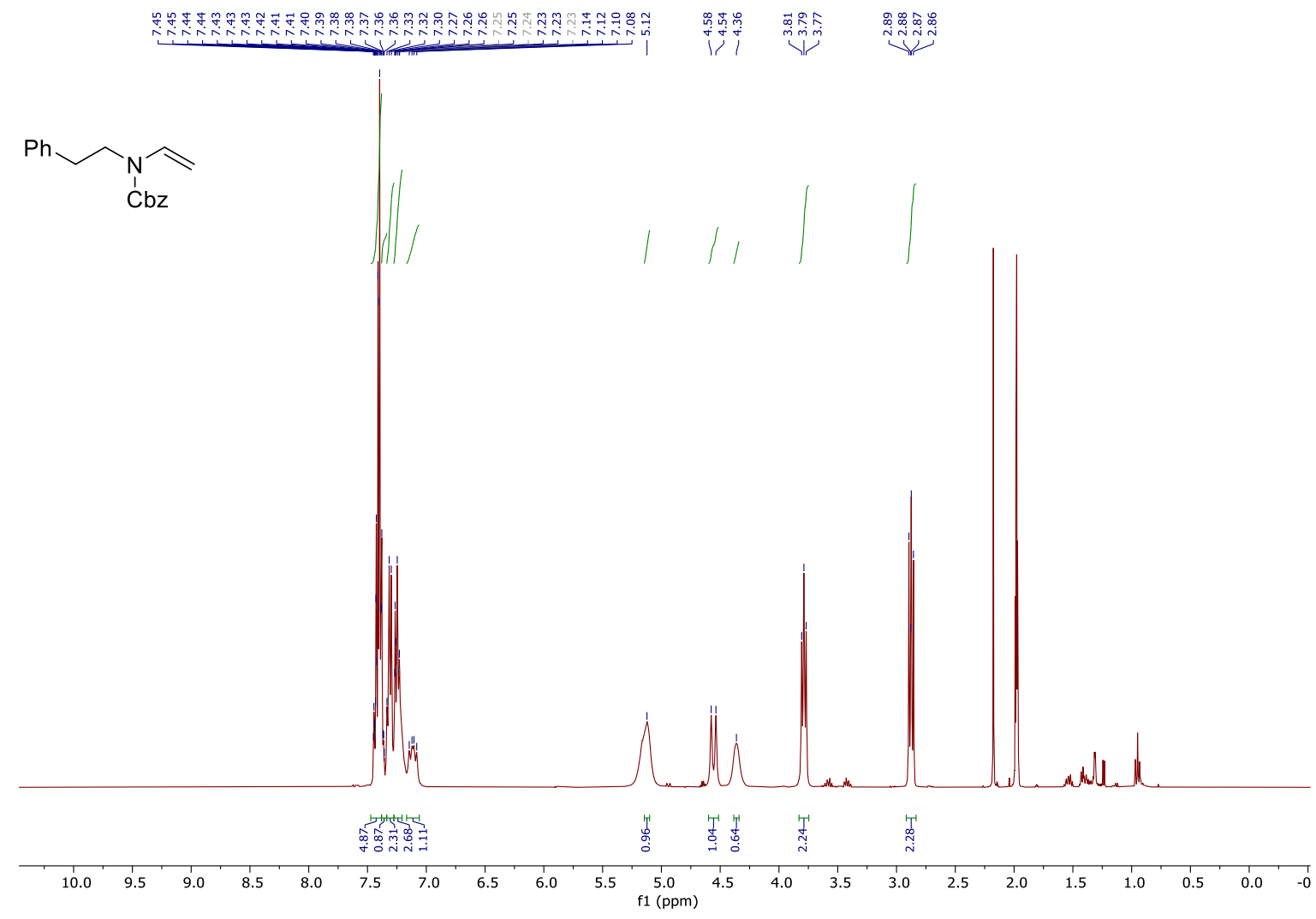

${ }^{13} \mathrm{C}$ NMR (101 MHz, Acetonitrile- $\left.d_{3}\right)$

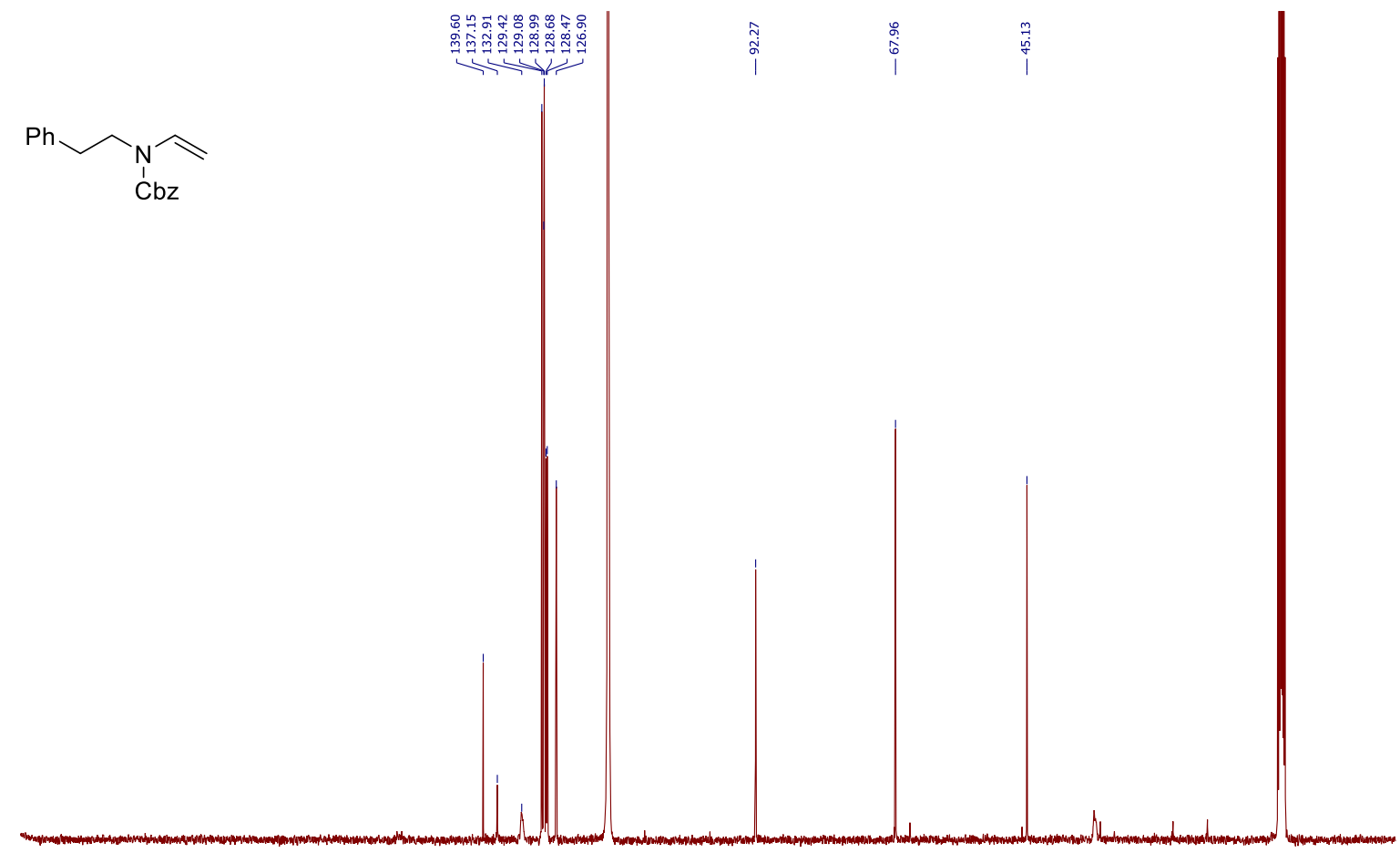

$\begin{array}{llllllllllllllllllllllllll}1 & 20 & 210 & 200 & 190 & 180 & 170 & 160 & 150 & 140 & 130 & 120 & 110 & 100 & 90 & 80 & 70 & 60 & 50 & 40 & 30 & 20 & 10 & 0 & -10\end{array}$ 
tert-butyl benzyl(vinyl)carbamate (1d)

${ }^{1} \mathrm{H}$ NMR $\left(400 \mathrm{MHz}\right.$, DMSO- $\left.d_{6}\right)$

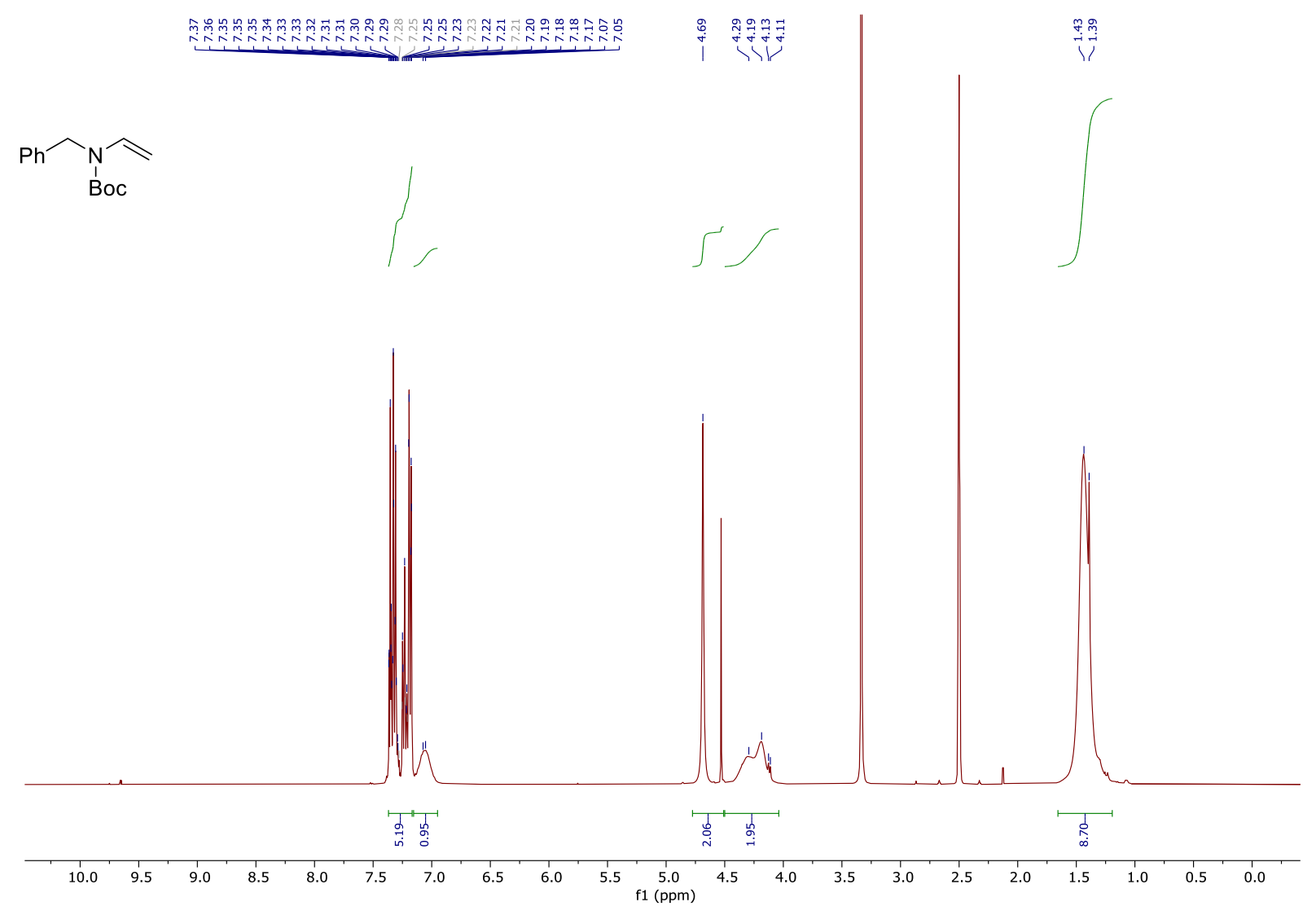


tert-butyl methyl(vinyl)carbamate (1e) $1 \mathrm{H}$ NMR (400 MHz, Acetonitrile- $\left.d_{3}\right)$
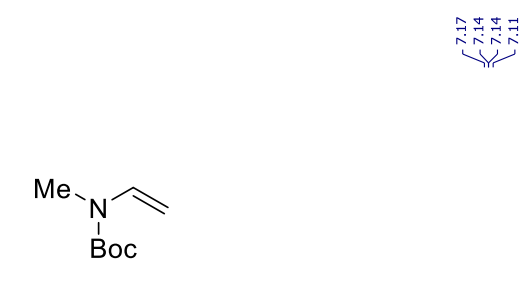

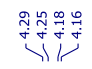

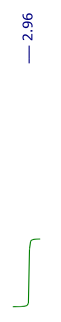

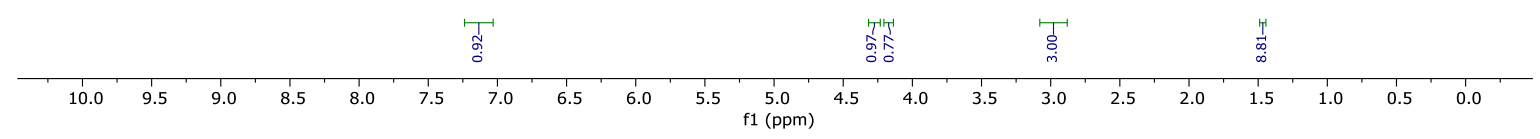

${ }^{13} \mathrm{C}$ NMR (101 MHz, Acetonitrile- $\left.d_{3}\right)$
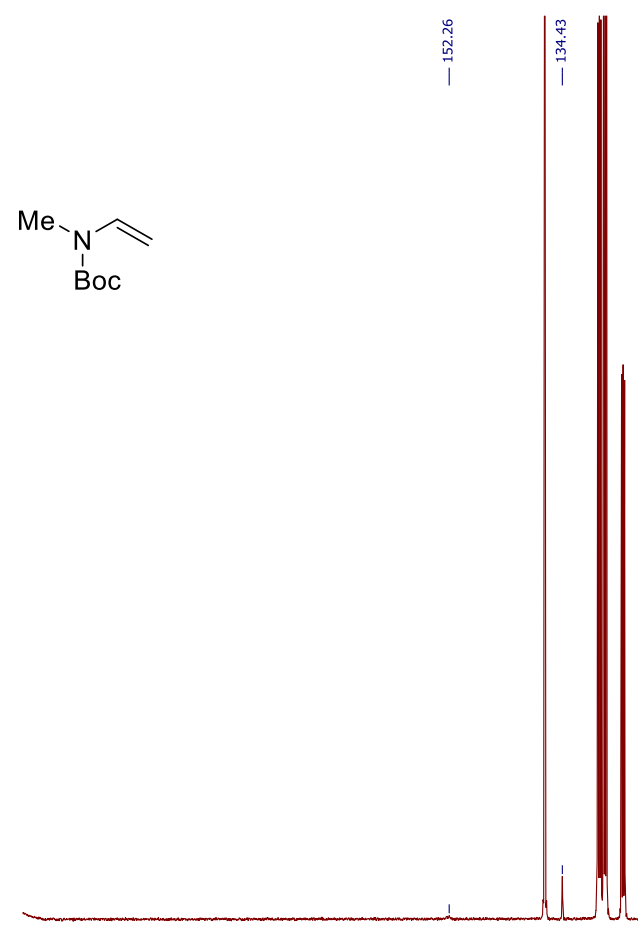

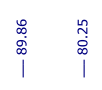

רัำ
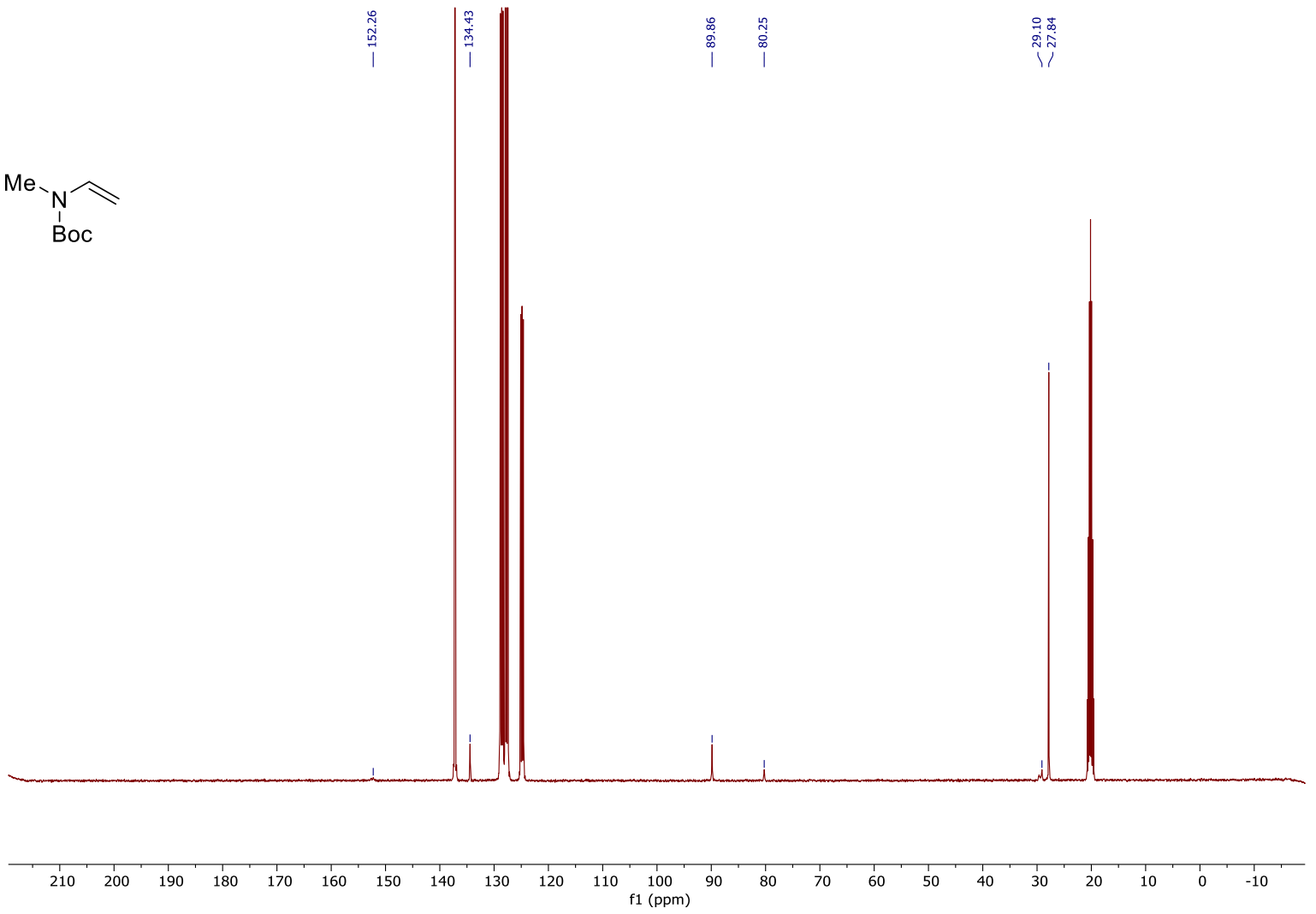

S56 
tert-Butyl allyl(vinyl)carbamate (1f)

${ }^{1} \mathrm{H}$ NMR (400 MHz, Chloroform-d)

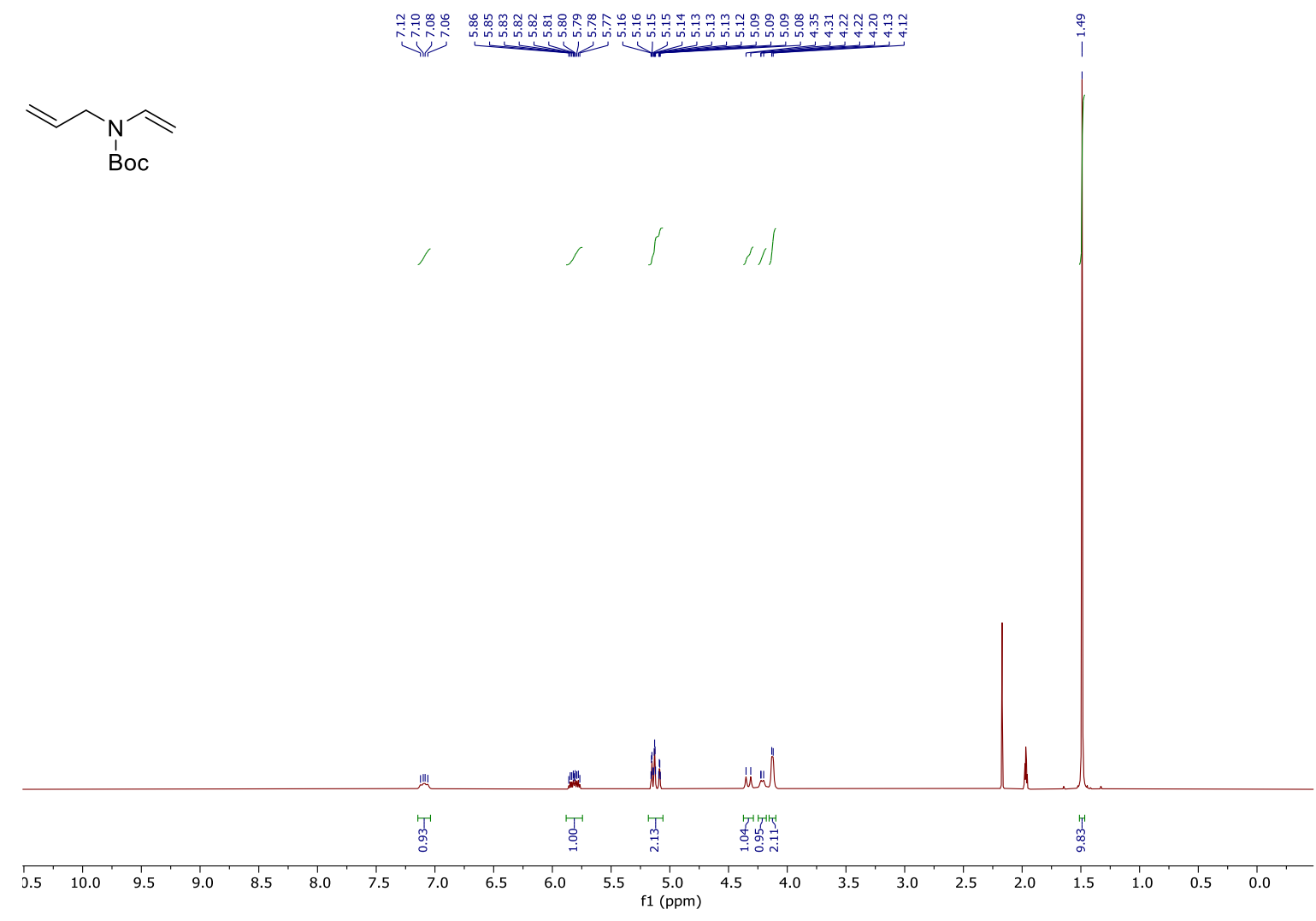

${ }^{13} \mathrm{C}$ NMR $(101 \mathrm{MHz}$, Chloroform-d)

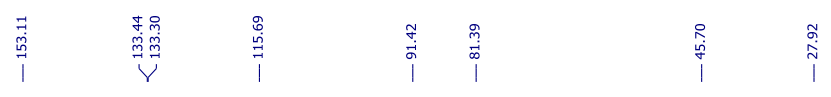
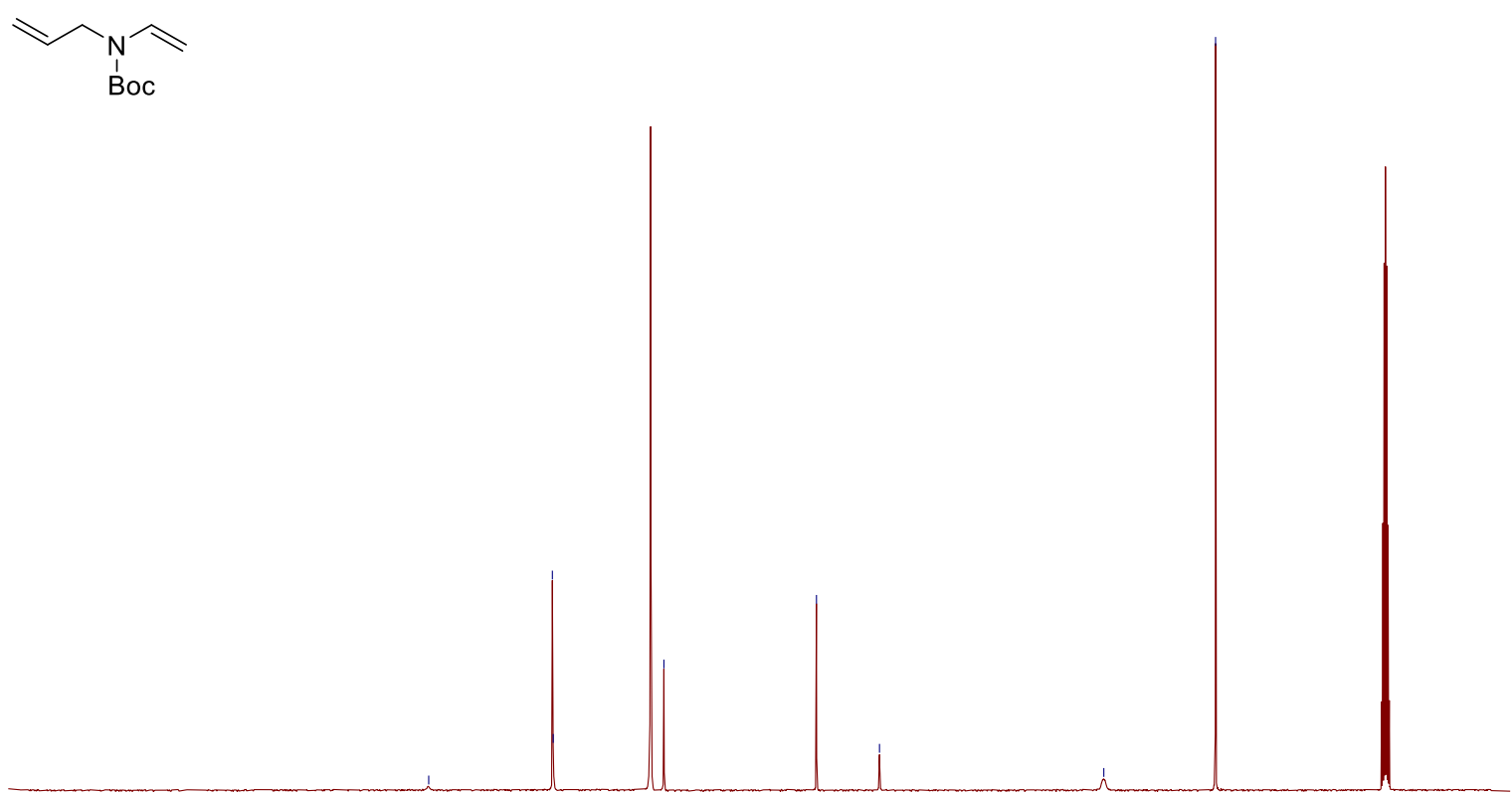

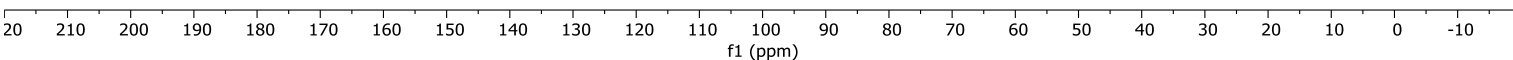


tert-Butyl (2-tert-butyldimethylsilyl)oxy)ethyl)(vinyl)carbamate (19)

${ }^{1} \mathrm{H}$ NMR $(400 \mathrm{MHz}$, Chloroform-d)

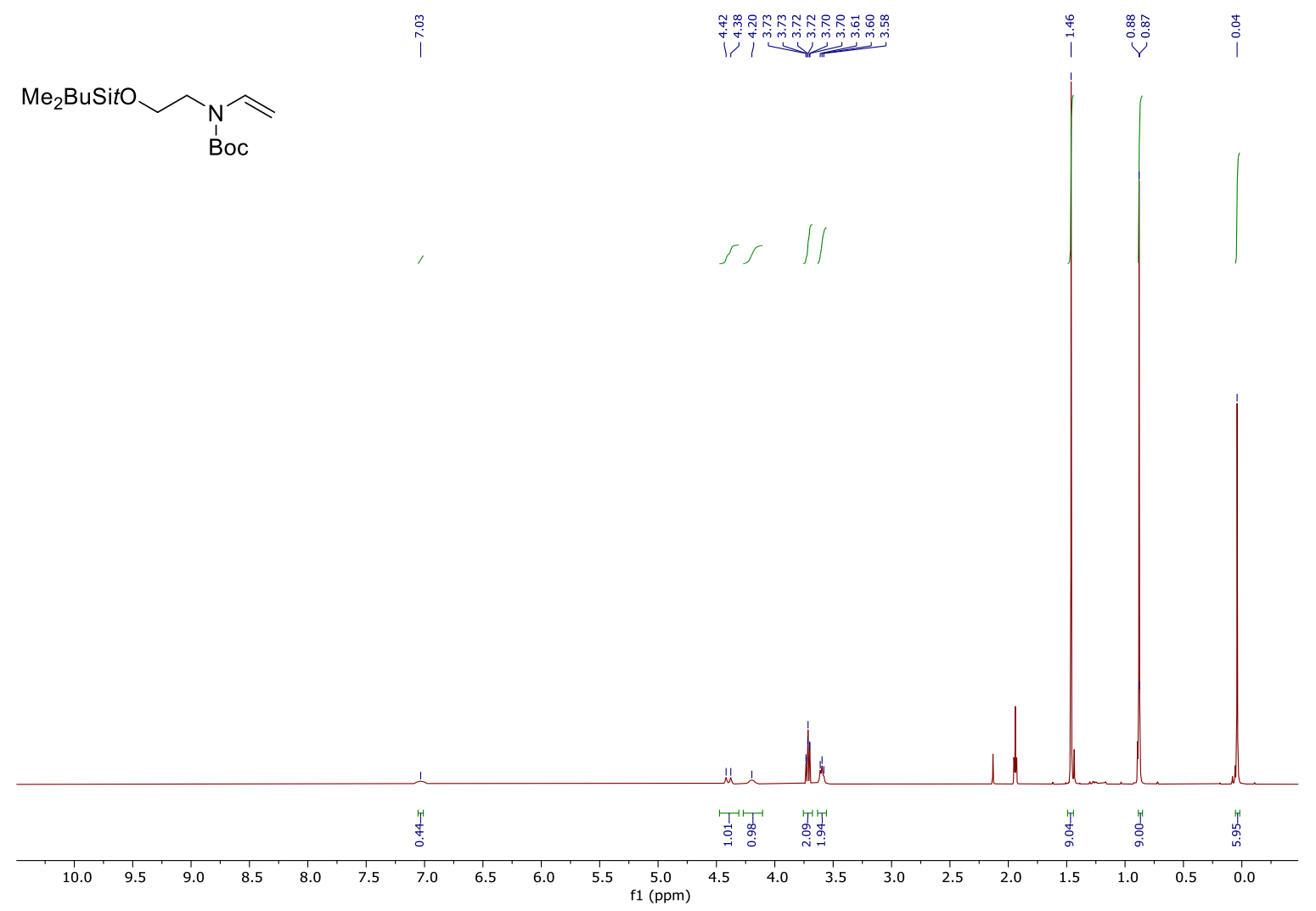

${ }^{13} \mathrm{C}$ NMR (101 MHz, Chloroform-d)

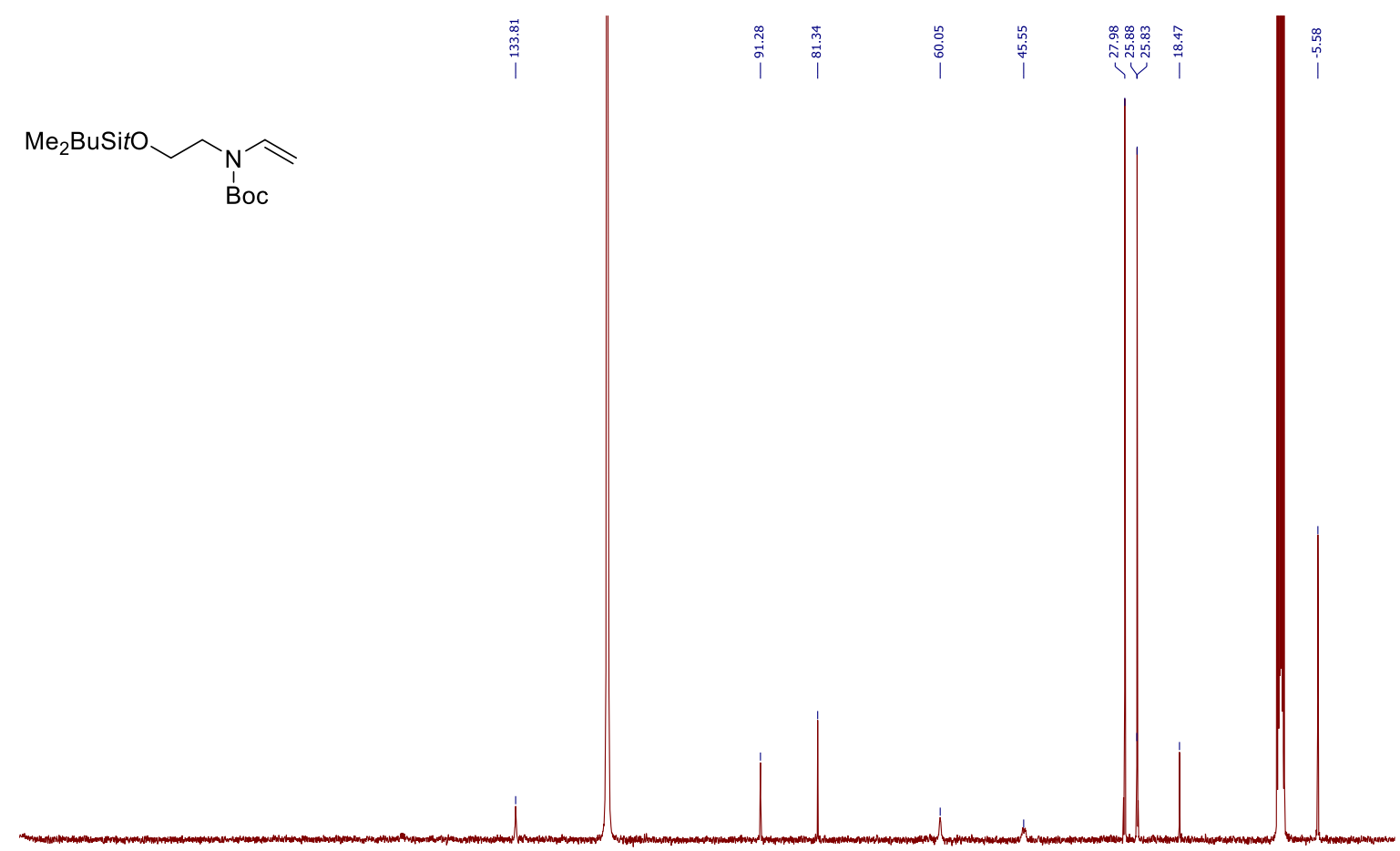

\begin{tabular}{lllllllllllllllllllllllll}
\hline & 210 & 200 & 190 & 180 & 170 & 160 & 150 & 140 & 130 & 120 & 110 & 100 & 90 & 80 & 70 & 60 & 50 & 40 & 30 & 20 & 10 & 0 & -10
\end{tabular} 
Ethyl 3-((tert-butoxycarbonyl)(vinyl)amino)propanoate (1 h) ${ }^{1} \mathrm{H}$ NMR $(400 \mathrm{MHz}$, Chloroform- $d$ )

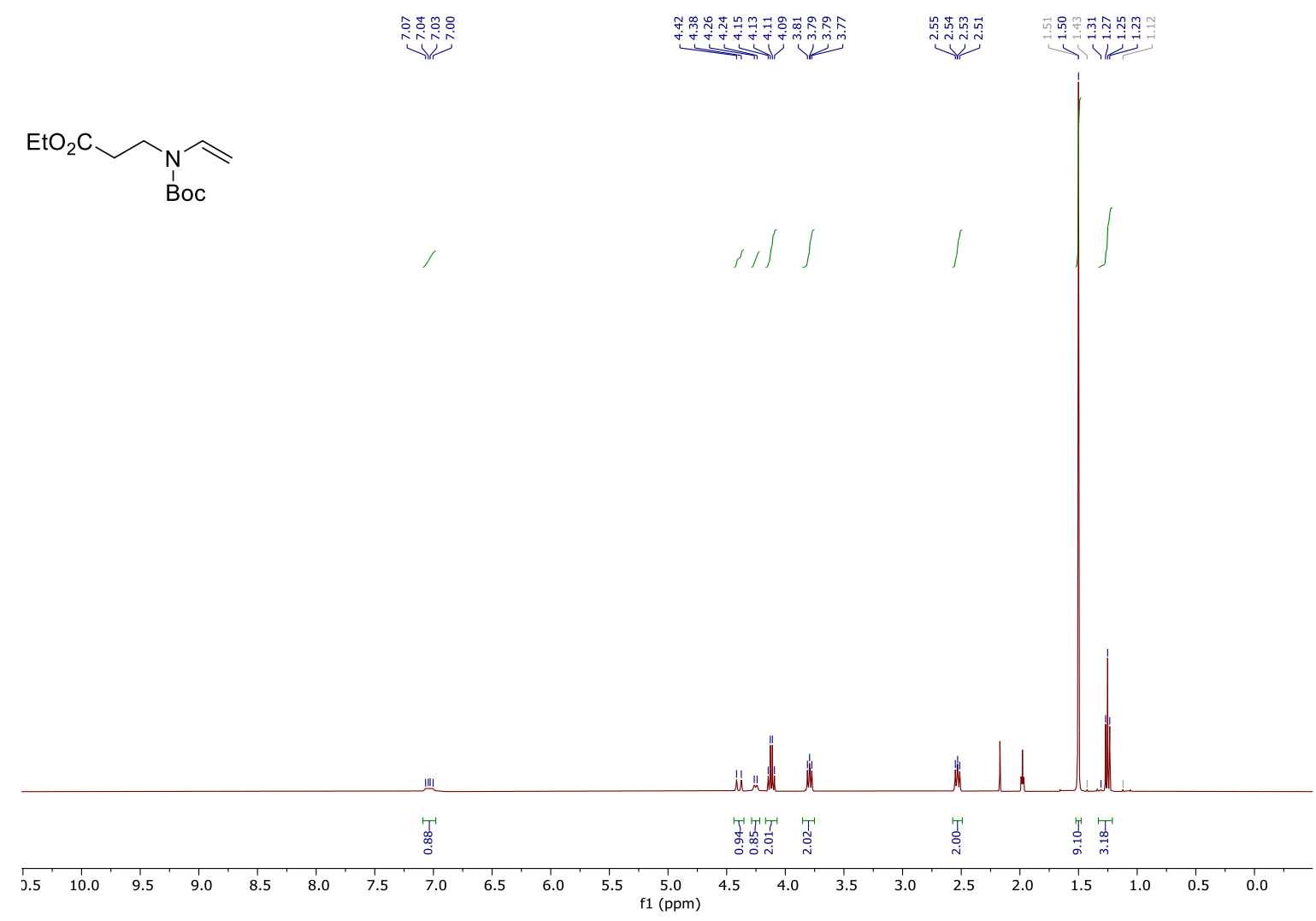

${ }^{13} \mathrm{C}$ NMR (101 MHz, Chloroform-d)

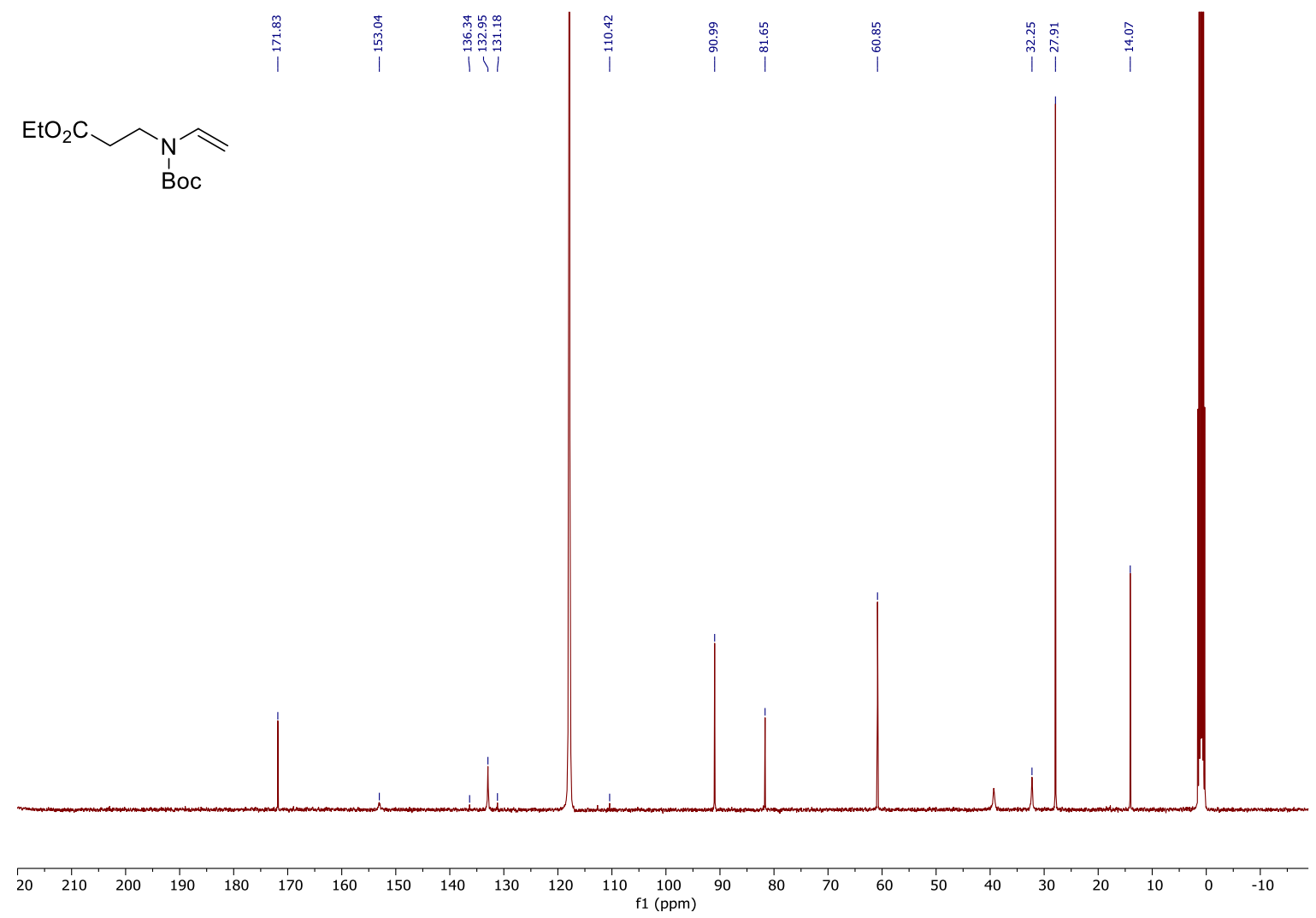


tert-Butyl cyclohexyl(vinyl)carbamate (1i)

${ }^{1} \mathrm{H}$ NMR (400 MHz, Chloroform-d)

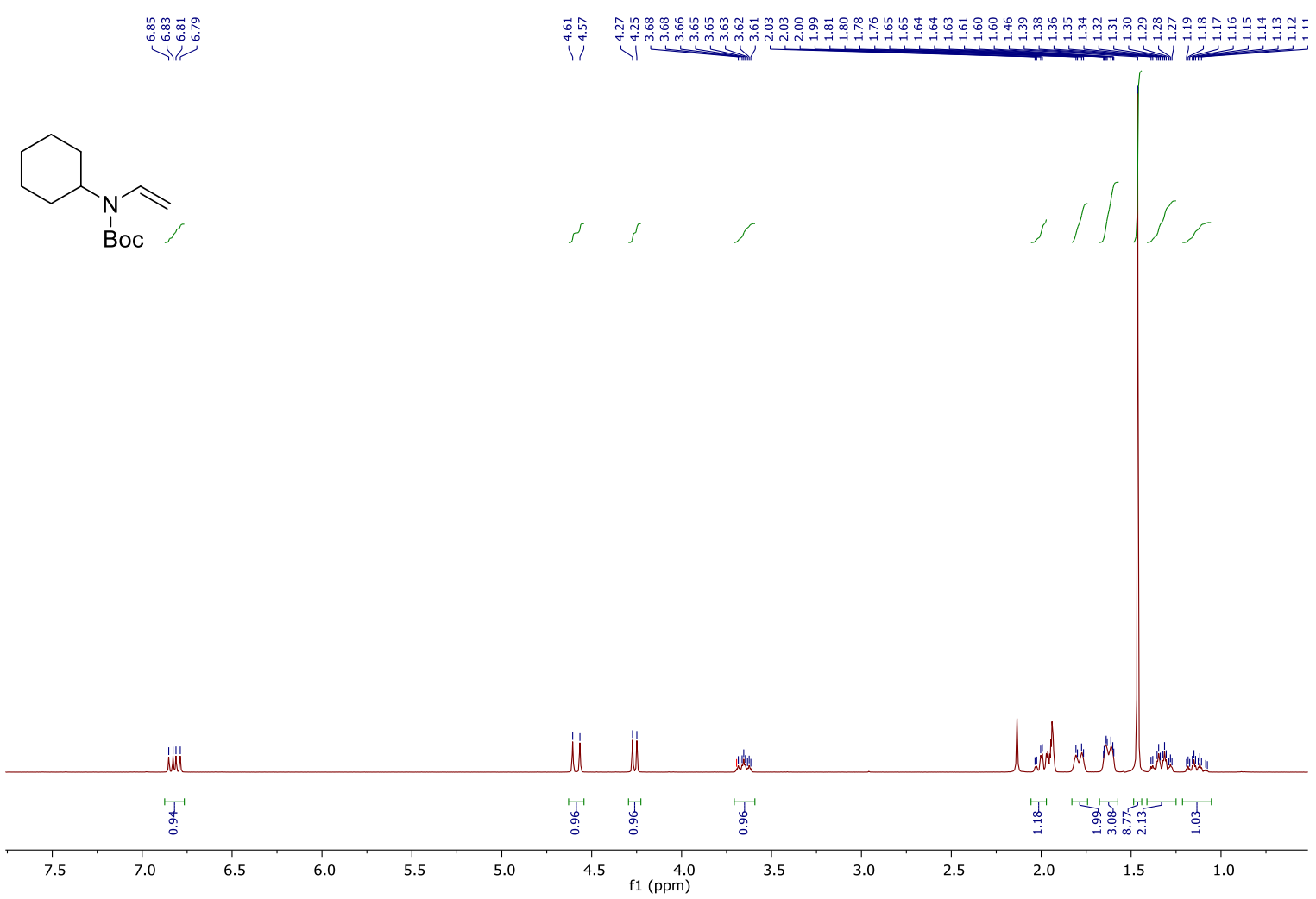

${ }^{13} \mathrm{C}$ NMR (101 MHz, Chloroform-d)

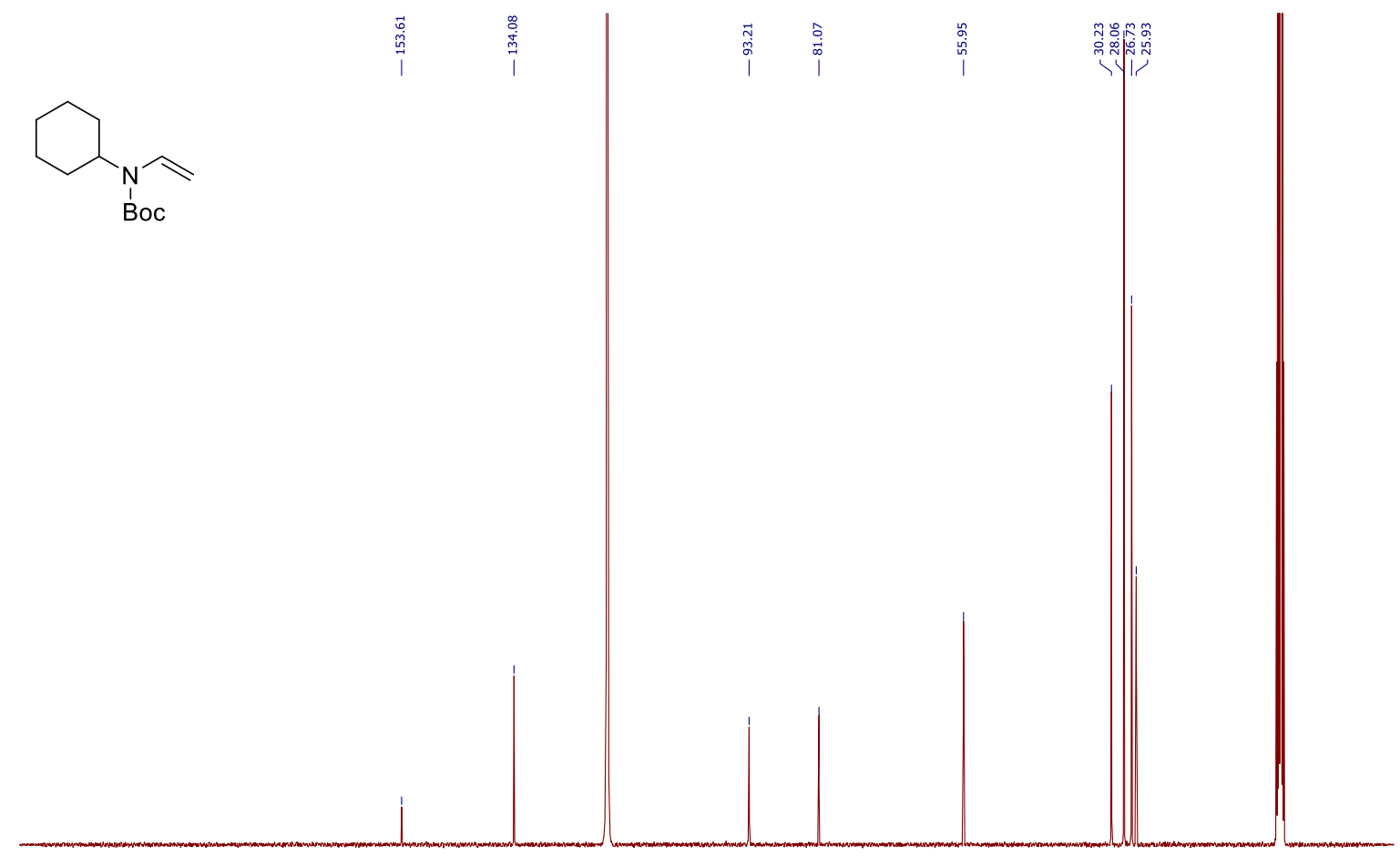

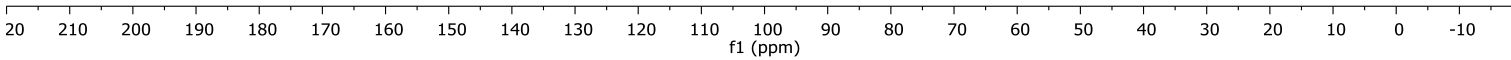


Benzyl phenethyl(propen-2-yl)carbamate (1/k)

${ }^{1} \mathrm{H}$ NMR (400 MHz, Chloroform-d)

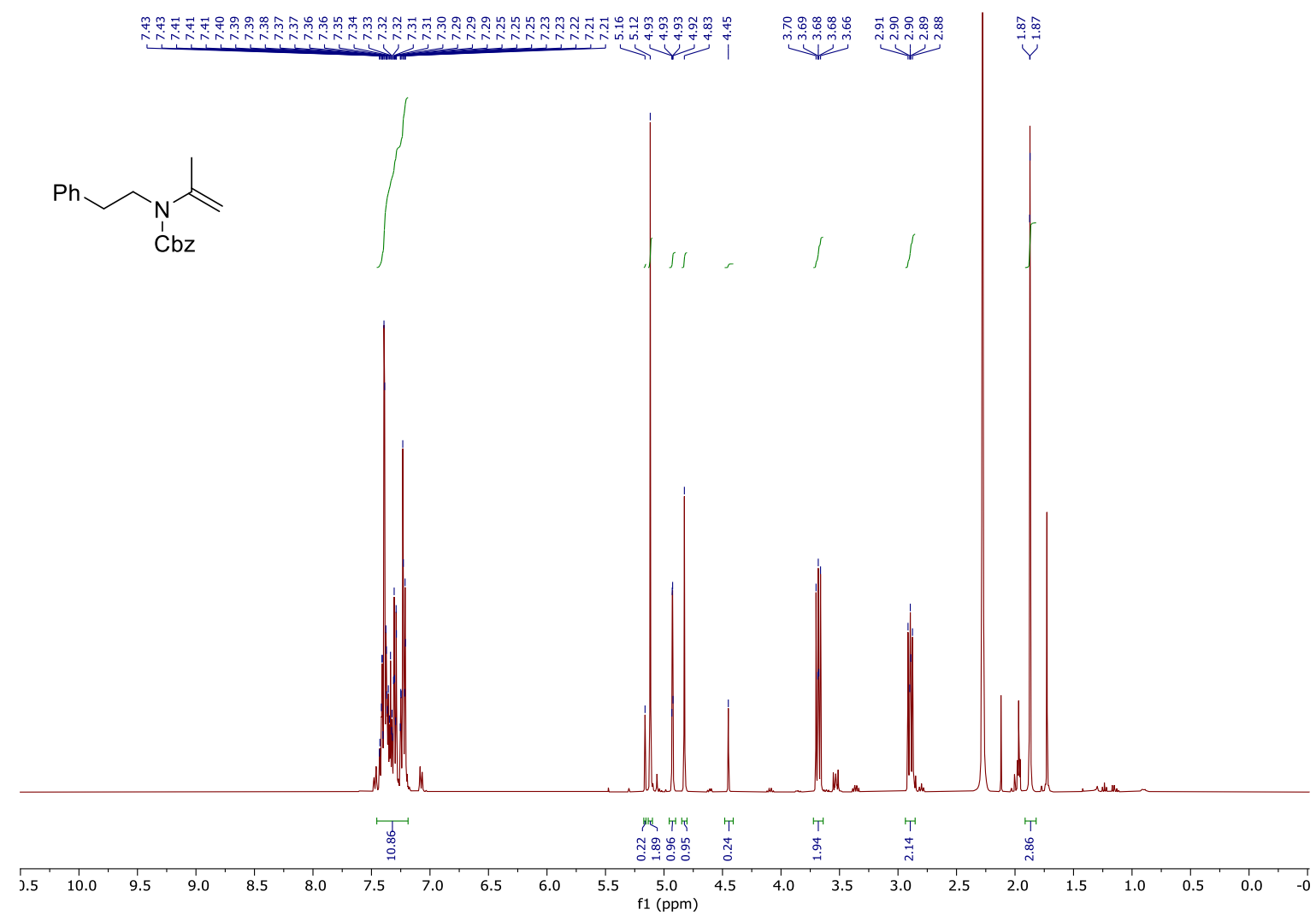

${ }^{13} \mathrm{C}$ NMR (101 MHz, Chloroform-d)

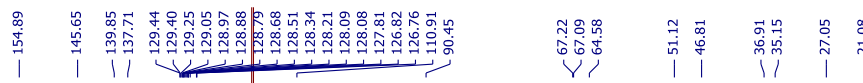<smiles>C=C(C)N(CCCC)CCc1ccccc1</smiles>

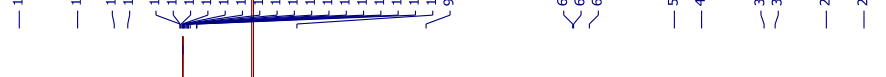

$\begin{array}{llllllllllllllllllllllllllll}1 & 210 & 200 & 190 & 180 & 170 & 160 & 150 & 140 & 130 & 120 & 110 & 100 & 90 & 80 & 70 & 60 & 50 & 40 & 30 & 20 & 10 & 0 & -10 & 10\end{array}$ 
(E)-3-(hex-1-en-1-yl)oxazolidine-2-one (1I) ${ }^{1} \mathrm{H}$ NMR (Chloroform- $d$ )

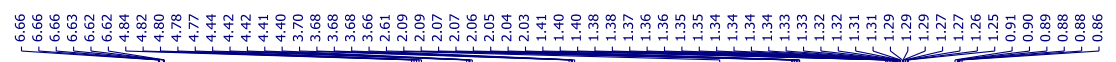

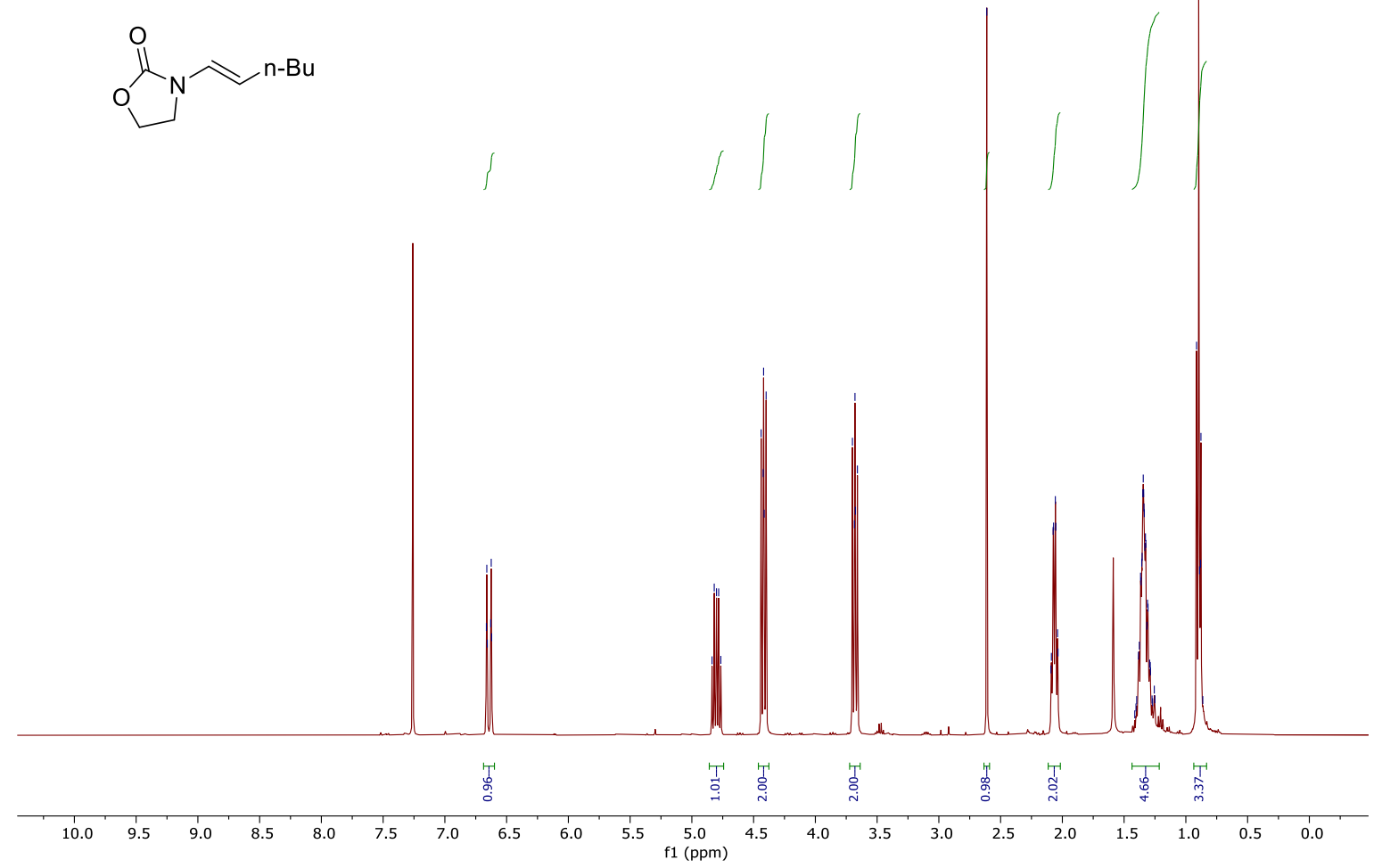


3-(hex-1-en-1-yl)oxazolidine-2-one (Z:E 2:1 1I + 1I')

${ }^{1} \mathrm{H}$ NMR (400 MHz, Benzene- $\left.d_{6}\right)$

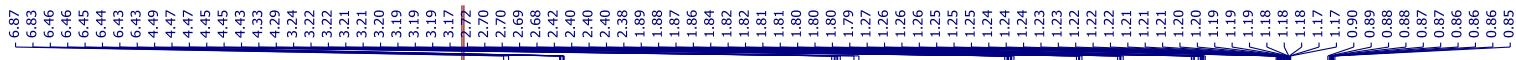<smiles>CCCCN1CCOC1=O</smiles>

Z:E 2:1

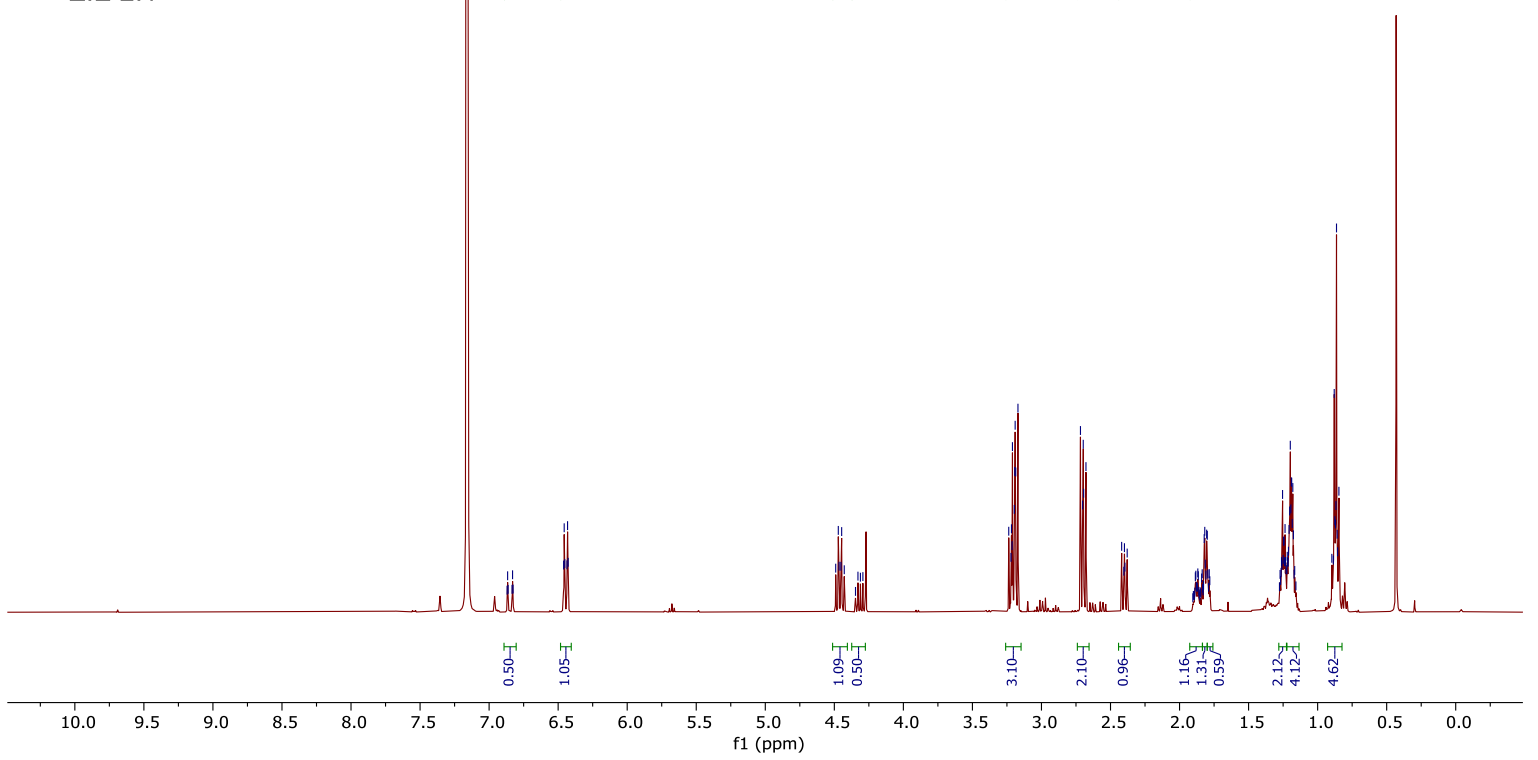

${ }^{13} \mathrm{C}$ NMR (101 MHz, Benzene- $\left.d_{6}\right)$<smiles>CCCCN1CCOC1=O</smiles>

Ylo

Z:E 2:1
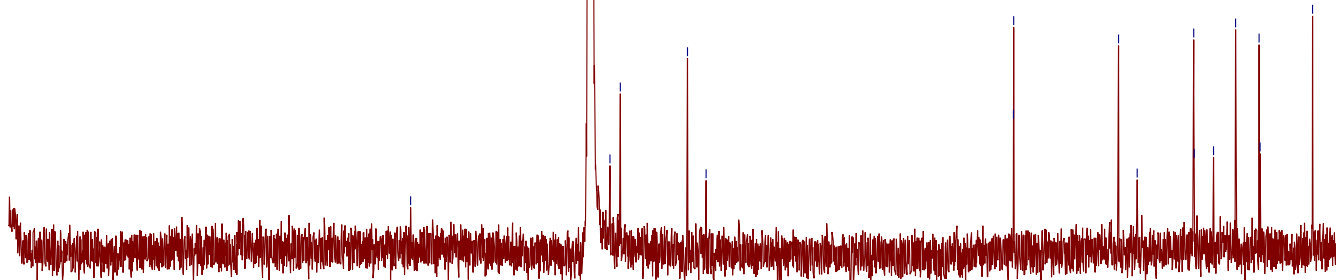

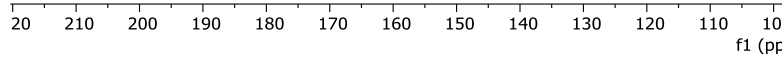

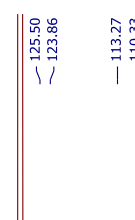


(E)-((hex-1-en-1-yloxy)methyl)benzene $(\mathbf{9 g})$

${ }^{1} \mathrm{H}$ NMR (400 MHz, Chloroform-d)

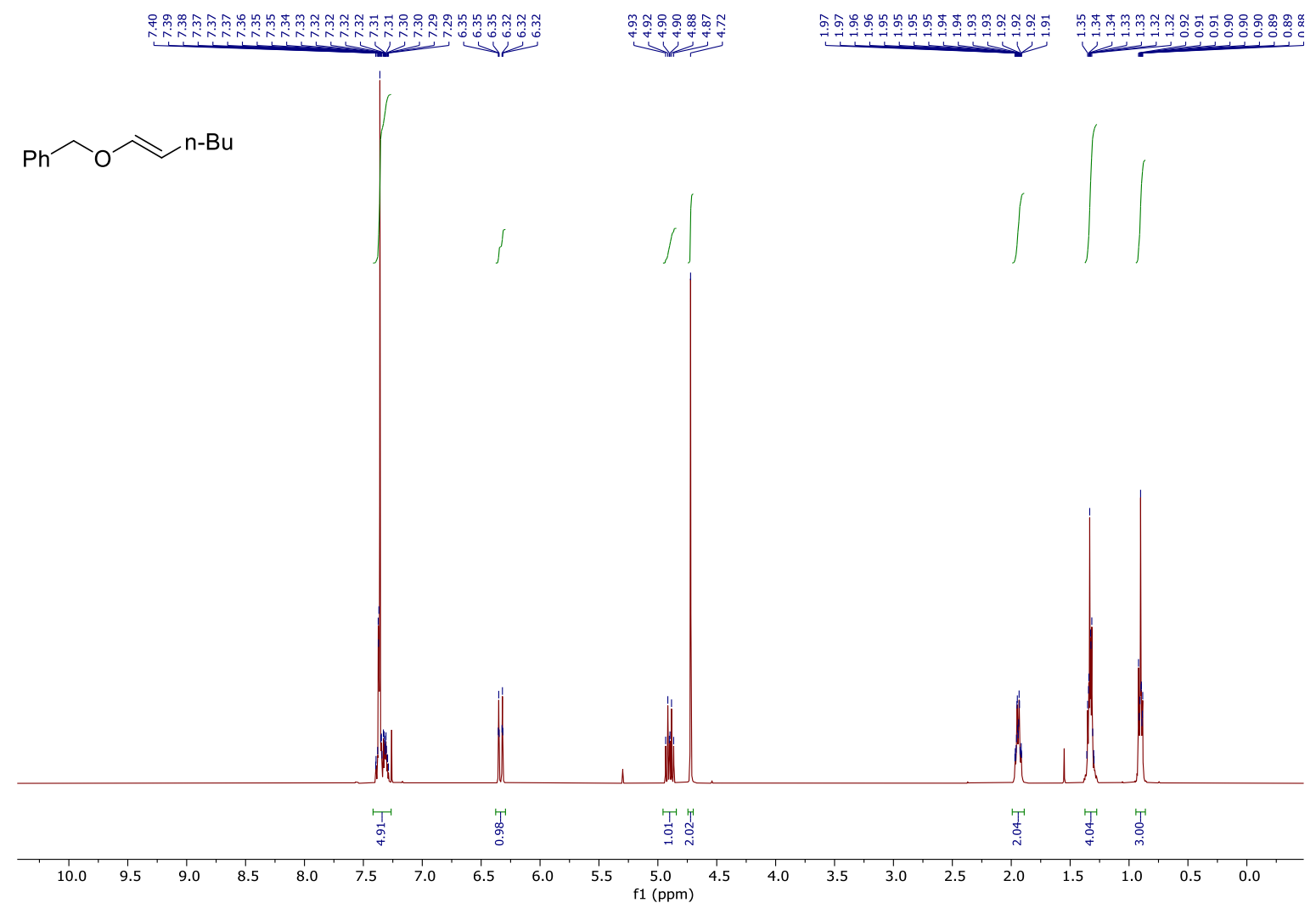

${ }^{13} \mathrm{C}$ NMR (101 MHz, Chloroform-d)

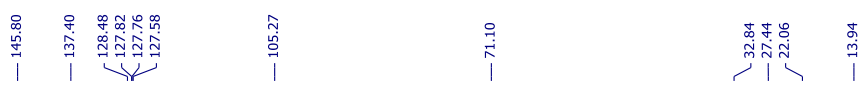

$\mathrm{Ph}_{\mathrm{O}} \curvearrowright \mathrm{n}-\mathrm{Bu}$

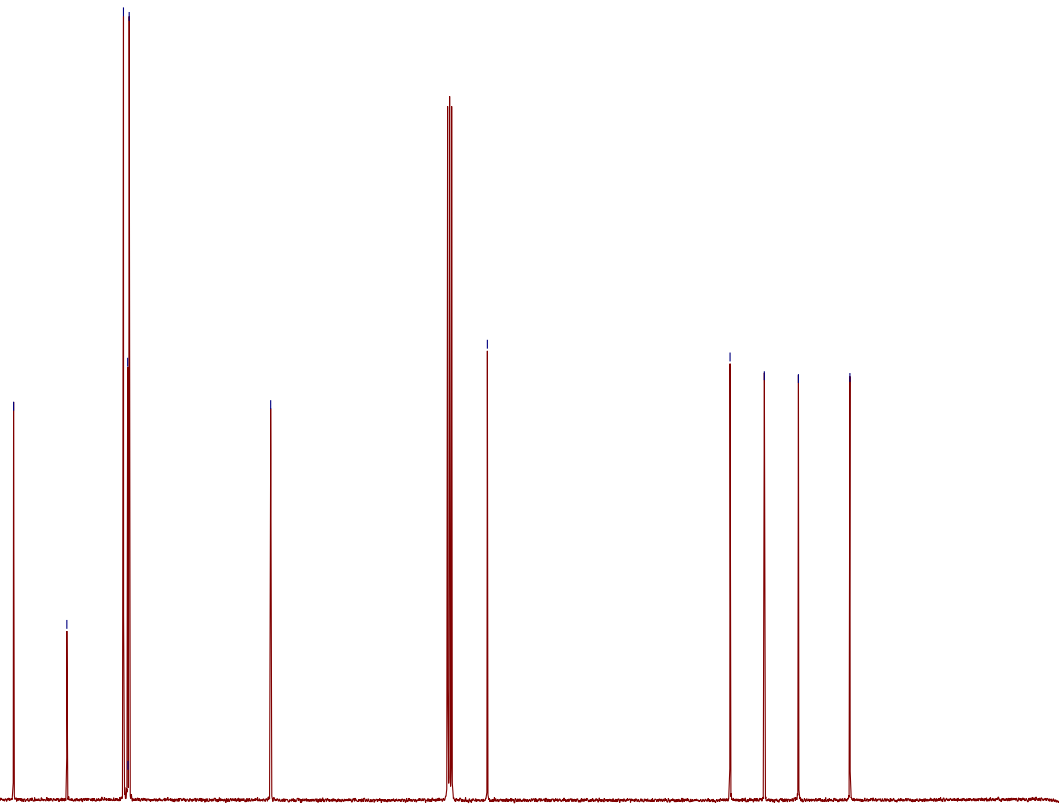

\begin{tabular}{lllllllllllllllllllllllllll}
\hline 10 & 200 & 190 & 180 & 170 & 160 & 150 & 140 & 130 & 120 & 110 & 100 & 90 & 80 & 70 & 60 & 50 & 40 & 30 & 20 & 10 & 0 & -10
\end{tabular} 


\section{Products}

2-(2-oxooxazolidin-3-yl)-4-phenylbut-3-yn-1-yl 2-iodo benzoate (3a) (traces of ethyl acetate)

${ }^{1} \mathrm{H}$ NMR $(400 \mathrm{MHz}$, Chloroform- $d$ )

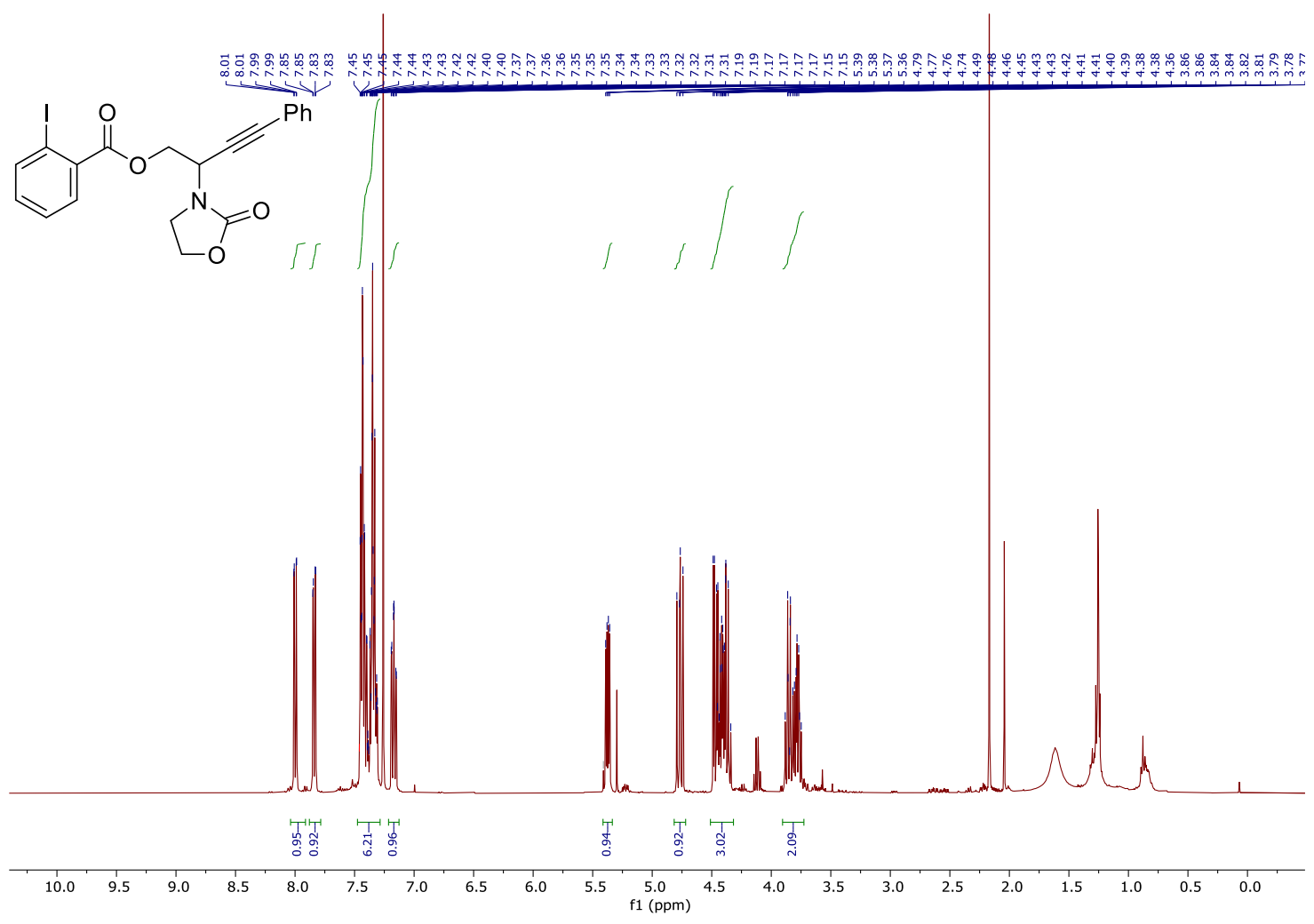

${ }^{13} \mathrm{C}$ NMR $(101 \mathrm{MHz}$, Chloroform- $d)$

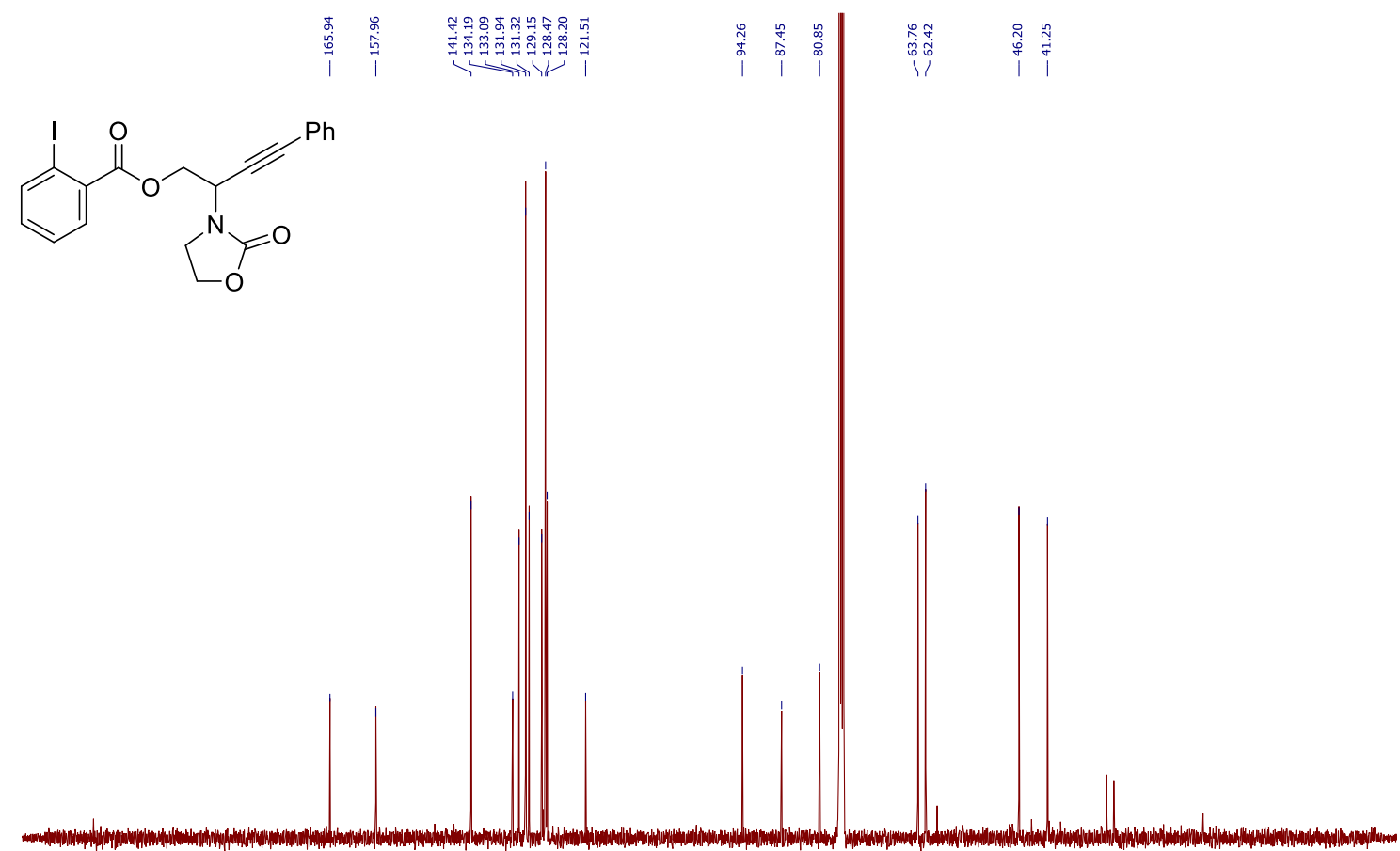

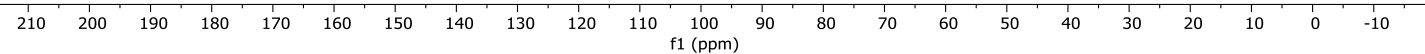


2-((tert-butoxycarbonyl)(phenethyl)amino)-4-phenylbut-3-yn-1-yl (3b)

${ }^{1} \mathrm{H}$ NMR (400 MHz, Acetonitrile- $d_{3}$ )

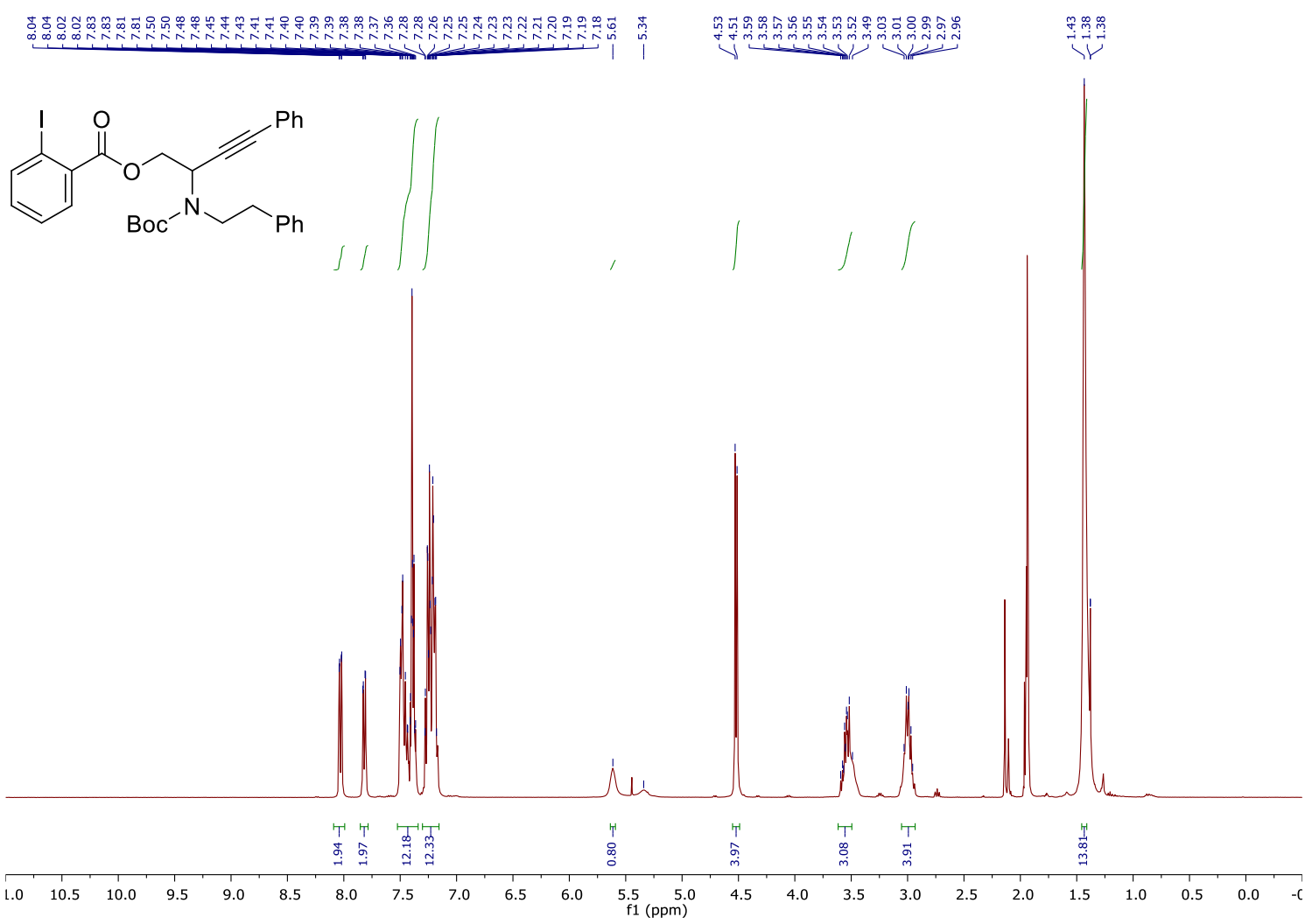

${ }^{13} \mathrm{C}$ NMR $\left(101 \mathrm{MHz}\right.$, Acetonitrile- $\left.d_{3}\right)$

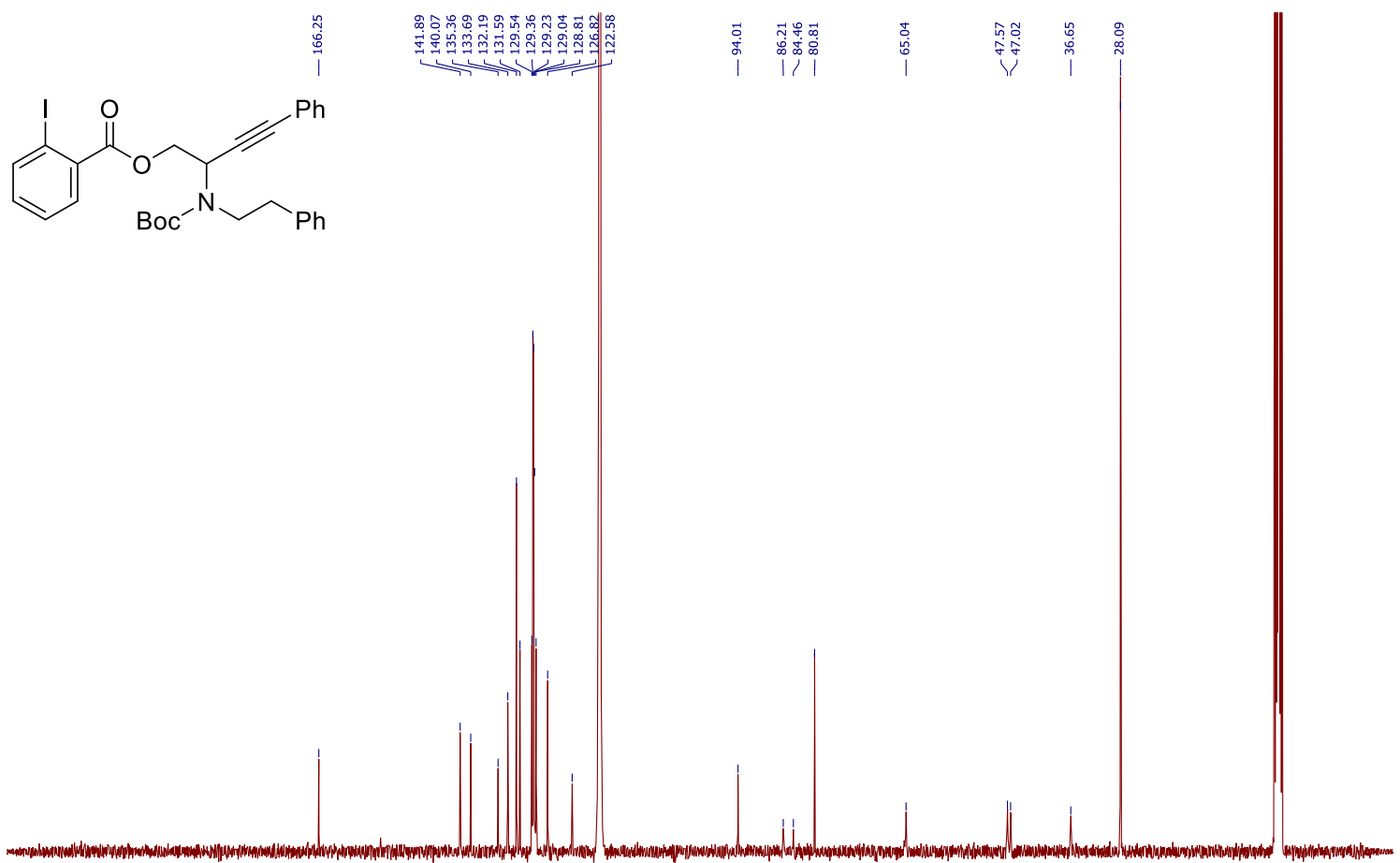

\begin{tabular}{lllllllllllllllllllllllllll}
\hline 20 & 210 & 200 & 190 & 180 & 170 & 160 & 150 & 140 & 130 & 120 & 110 & $\begin{array}{c}100 \\
\mathrm{f} 1(\mathrm{ppm})\end{array}$ & 90 & 80 & 70 & 60 & 50 & 40 & 30 & 20 & 10 & 0 & -10
\end{tabular} 
2-(((benzyloxy)carbonyl)(phenethyl)amino)-4-phenylbut-3-yn-1-yl 2-iodobenzoate (3c)

${ }^{1} \mathrm{H}$ NMR (400 MHz, Acetonitrile- $\left.d_{3}\right)$

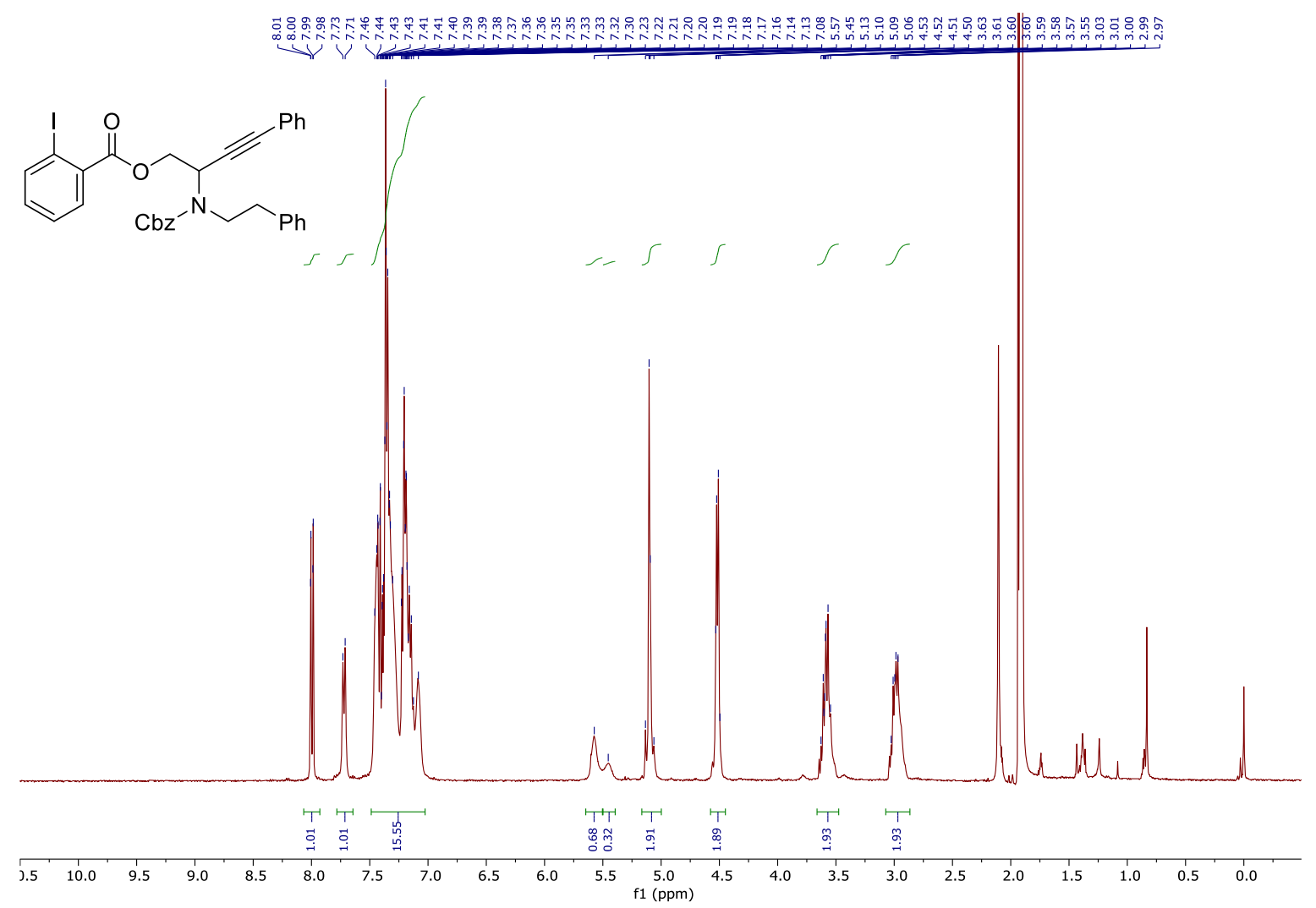

${ }^{13} \mathrm{C}$ NMR (101 MHz, Acetonitrile- $\left.d_{3}\right)$

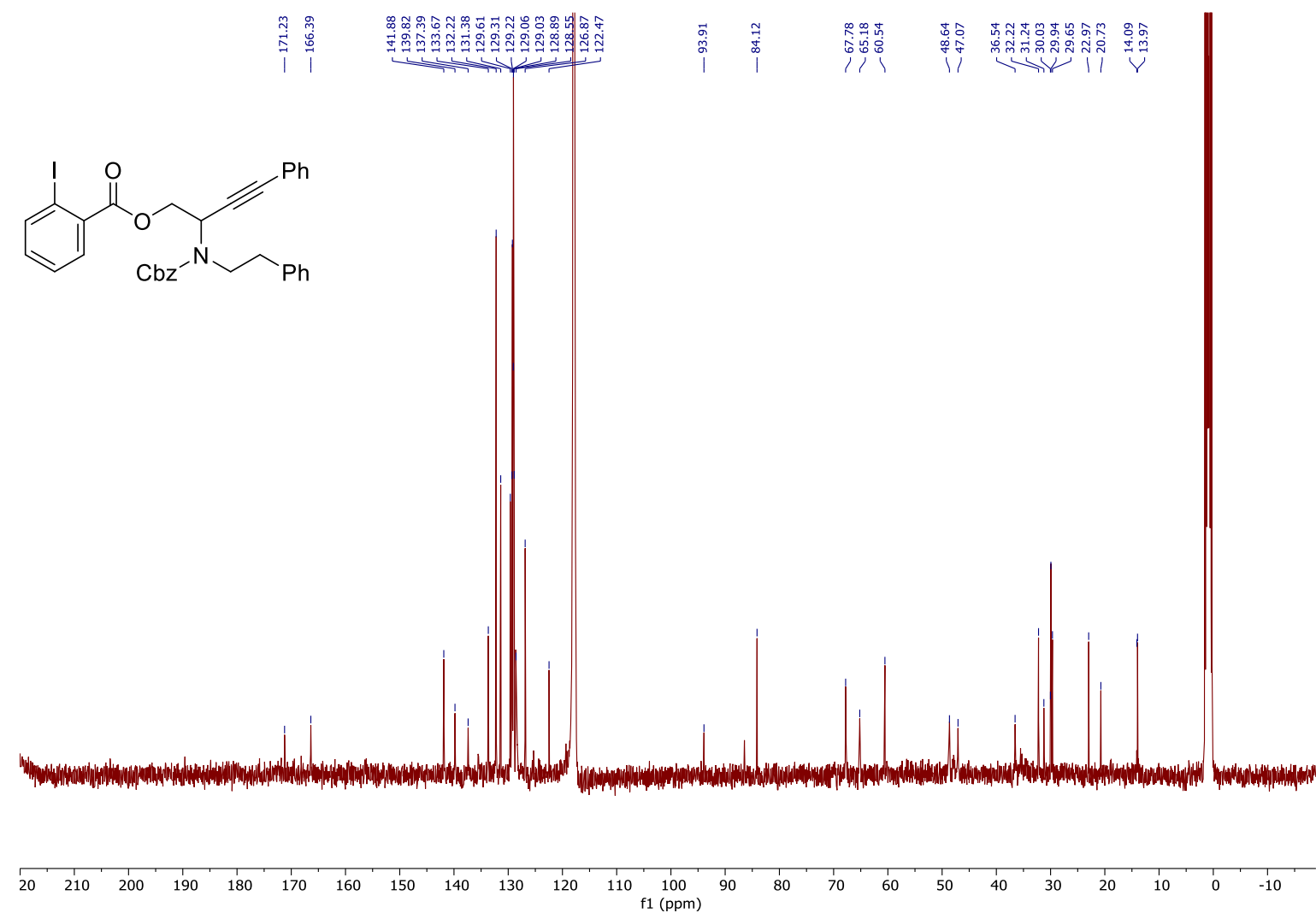


2-(benzyl(tert-butoxycarbonyl)amino)-4-phenylbut-3-yn-1-yl 2-iodobenzoate (3d) ${ }^{1} \mathrm{H}$ NMR $\left(400 \mathrm{MHz}\right.$, Acetonitrile- $\left.d_{3}\right)$

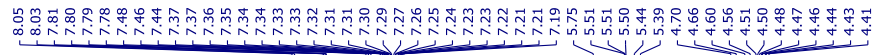<smiles>CC(C)(C)OC(=O)N(Cc1ccccc1)C(C#Cc1ccccc1)COC(=O)c1ccccc1I</smiles>
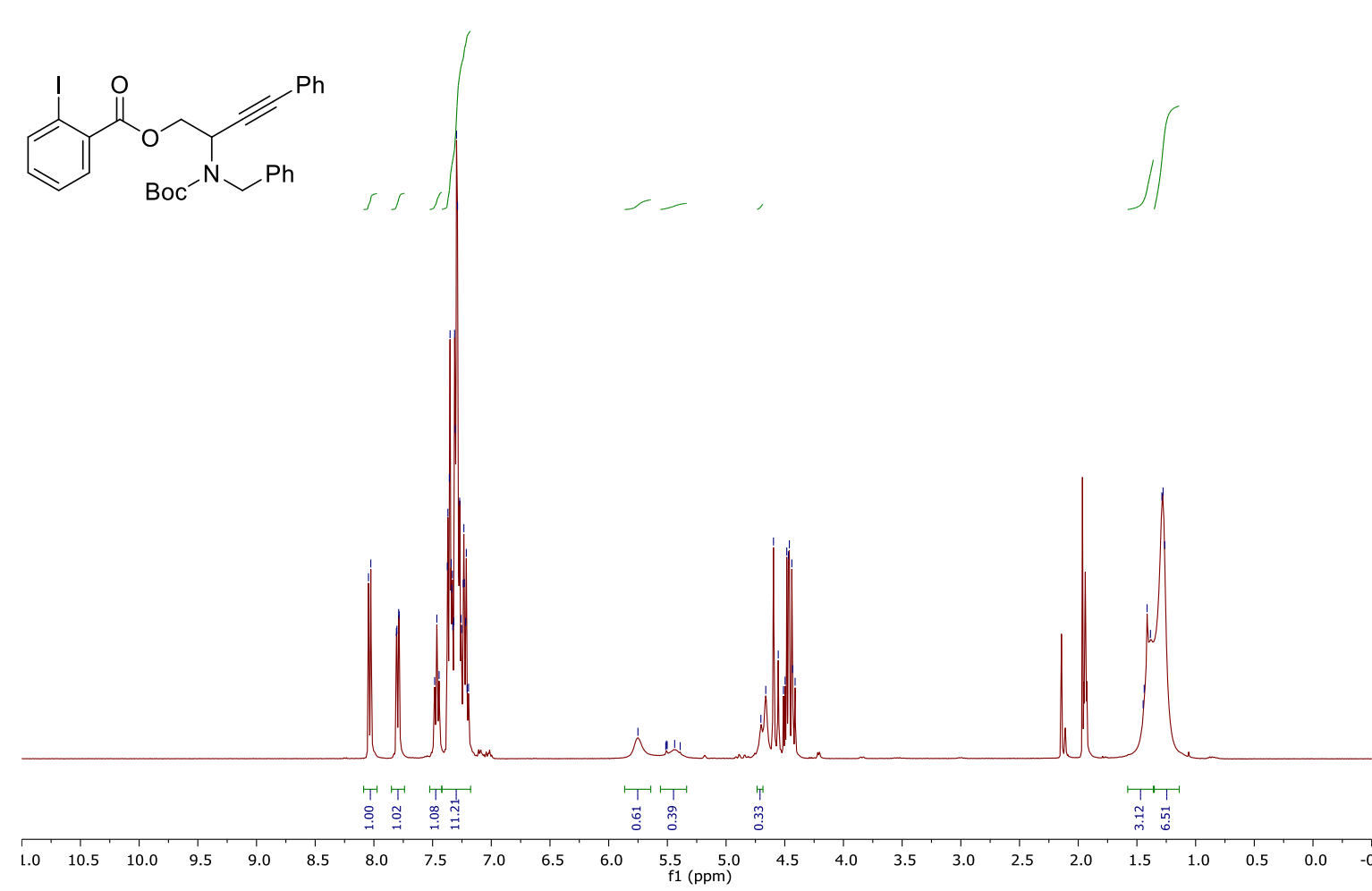

${ }^{13} \mathrm{C}$ NMR (101 MHz, Acetonitrile- $\left.d_{3}\right)$

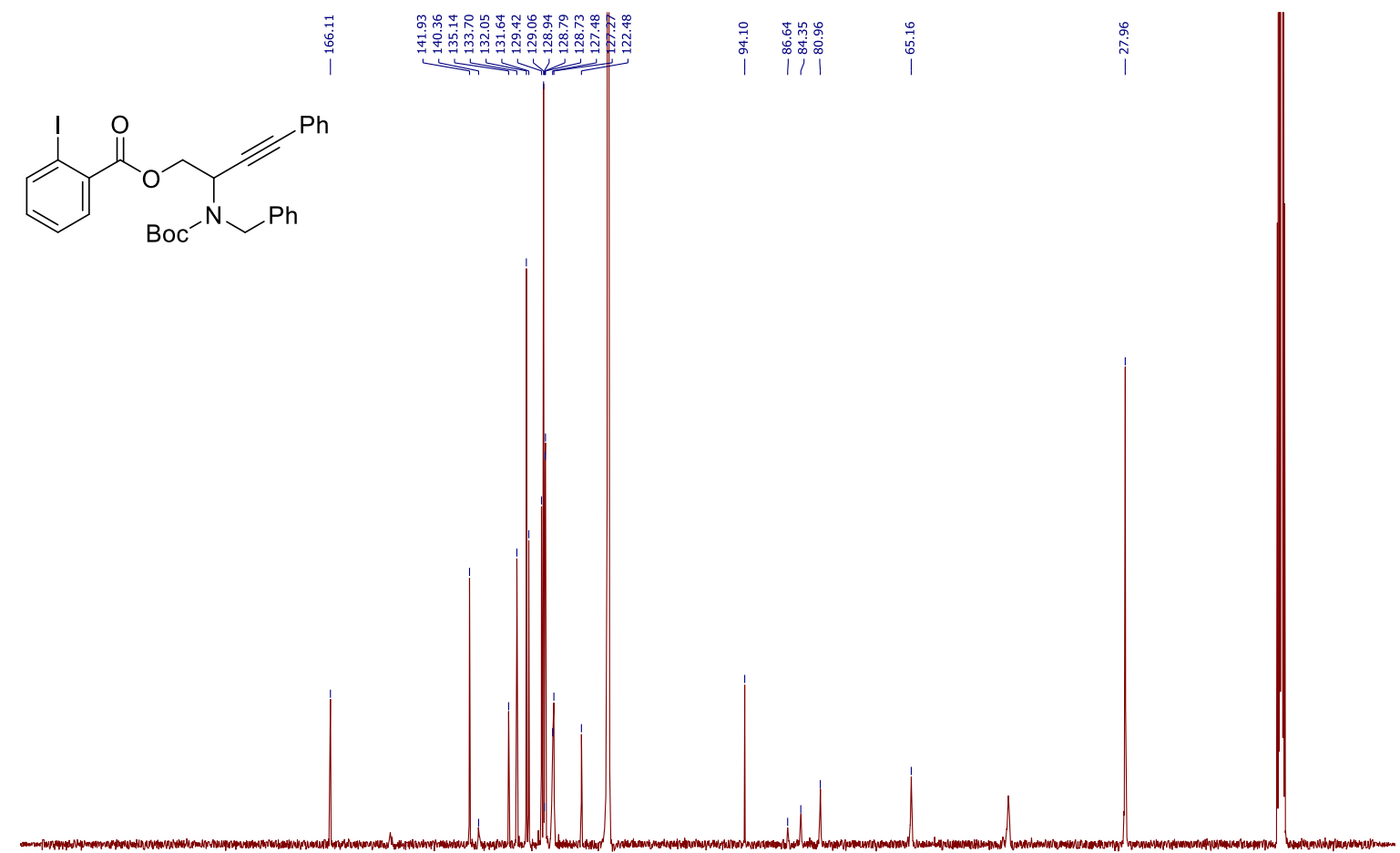

$\begin{array}{llllllllllllllllllllllll}20 & 210 & 200 & 190 & 180 & 170 & 160 & 150 & 140 & 130 & 120 & 110 & 100 & 90 & 80 & 70 & 60 & 50 & 40 & 30 & 20 & 10 & 0 & -10\end{array}$ 
2-(methyl(tert-butoxycarbonyl)amino)-4-phenylbut-3-yn-1-yl 2-iodobenzoate (3e) ${ }^{1} \mathrm{H}$ NMR $\left(400 \mathrm{MHz}\right.$, Acetonitrile- $d_{3}$ )

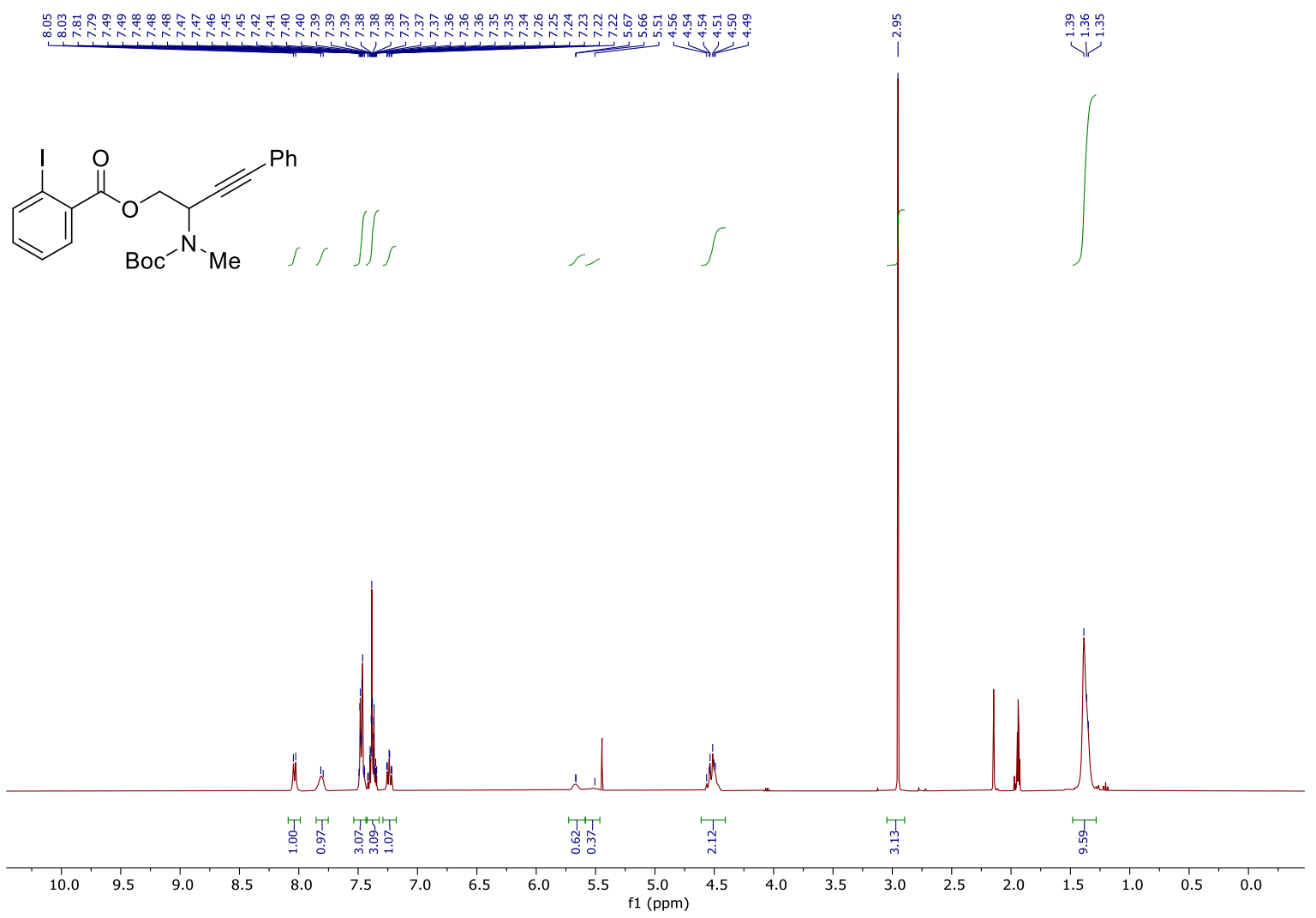

${ }^{13} \mathrm{C}$ NMR (101 MHz, Acetonitrile- $d_{3}$ )

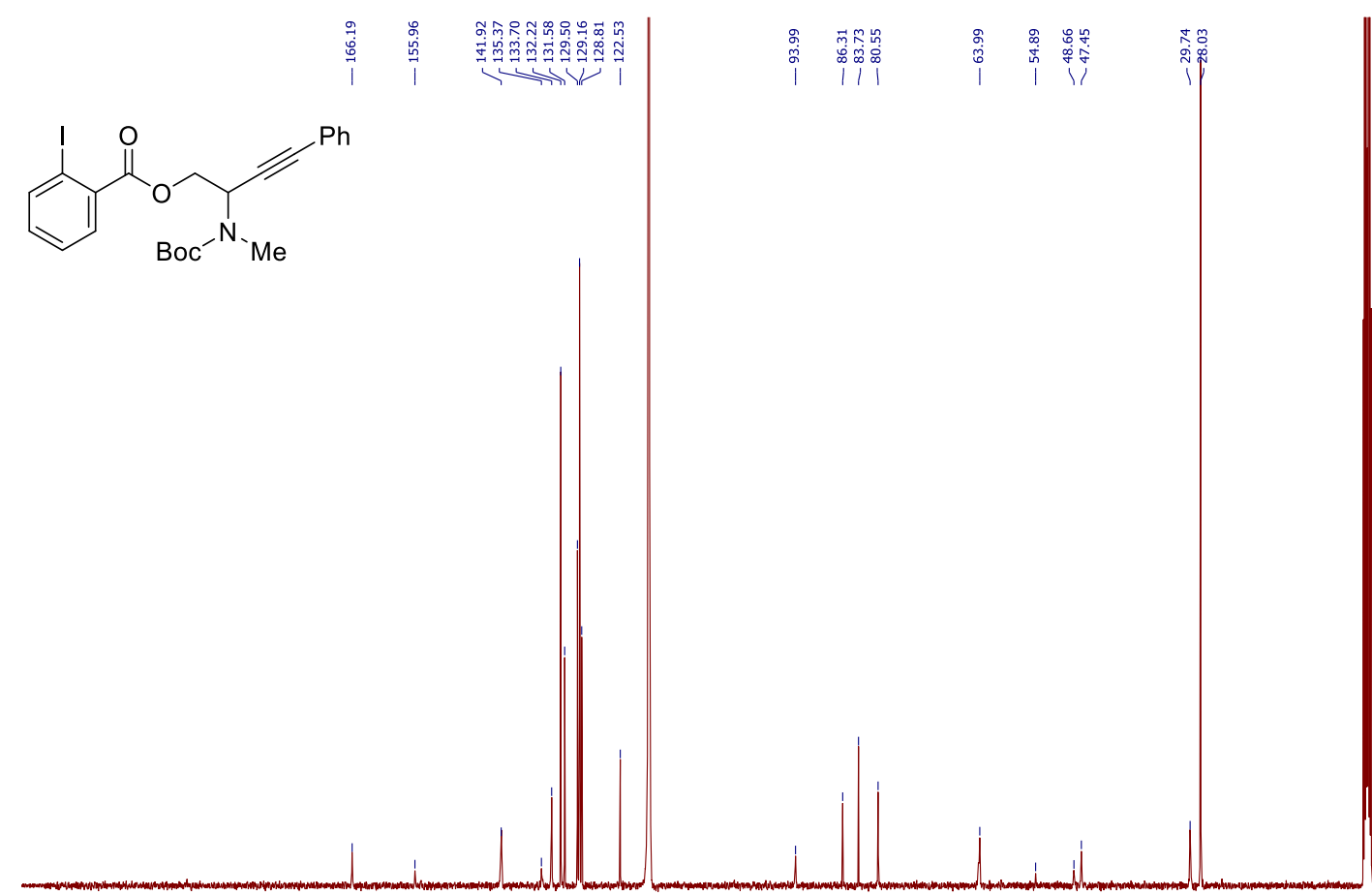

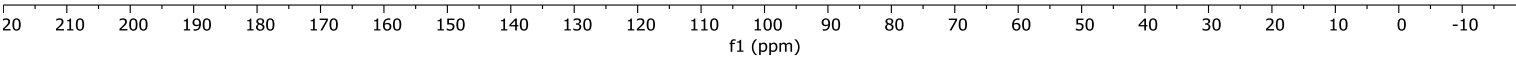


2-(allyl(tert-butoxycarbonyl)amino)-4-phenylbut-3-yn-1-yl 2-iodobenzoate (3f) ${ }^{1} \mathrm{H}$ NMR $\left(400 \mathrm{MHz}\right.$, Acetonitrile- $\left.d_{3}\right)$

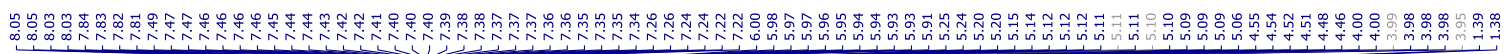<smiles>C=CCN(CC#CC(=O)OCc1ccccc1)C(C#CP)C(=O)OCc1ccccc1</smiles>
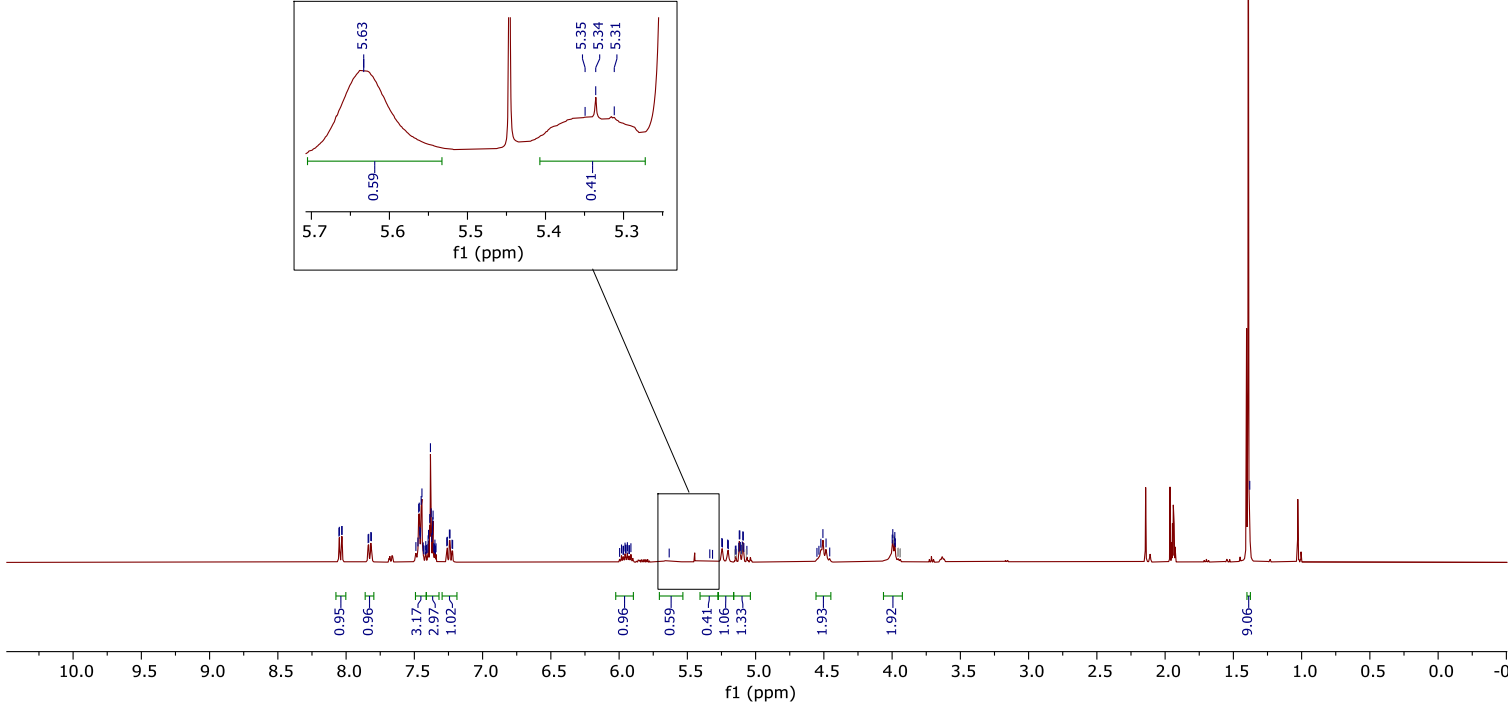

${ }^{13} \mathrm{C}\left(101 \mathrm{MHz}\right.$, Acetonitrile- $\left.d_{3}\right)$

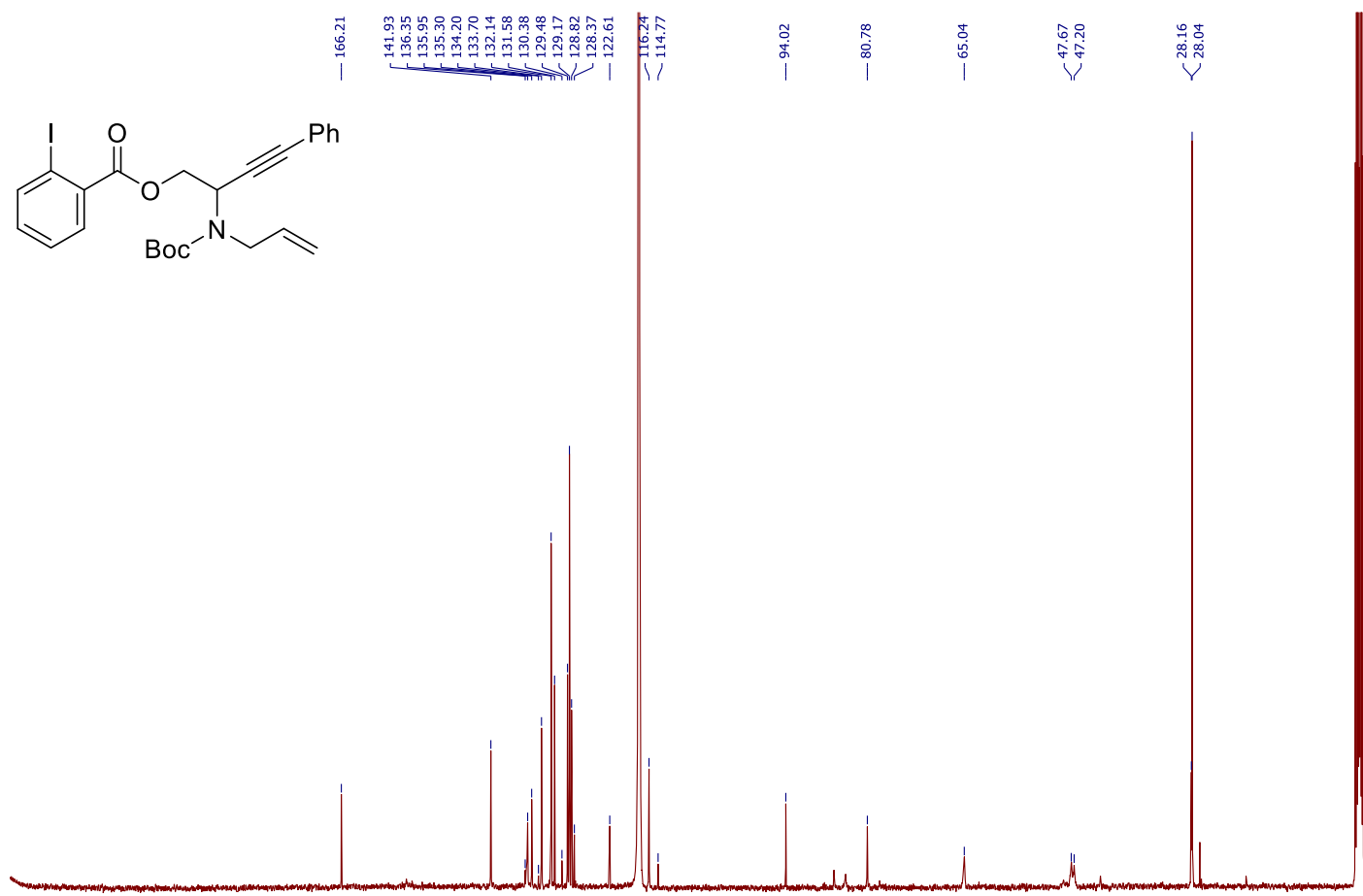

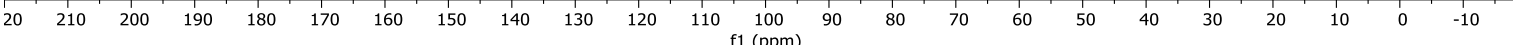


2-((tert-butoxycarbonyl)(2-((tert-butyldimethylsilyl)oxy)ethyl)amino)-4-phenylbut-3yn-1-yl 2-iodobenzoate (3g)

${ }^{1} \mathrm{H}$ NMR (400 MHz, Acetonitrile- $\left.d_{3}\right)$

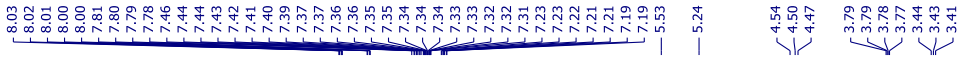<smiles>CCOCCN(C(=O)OCC)C(C#Cc1ccccc1)COC(=O)c1ccccc1I</smiles>
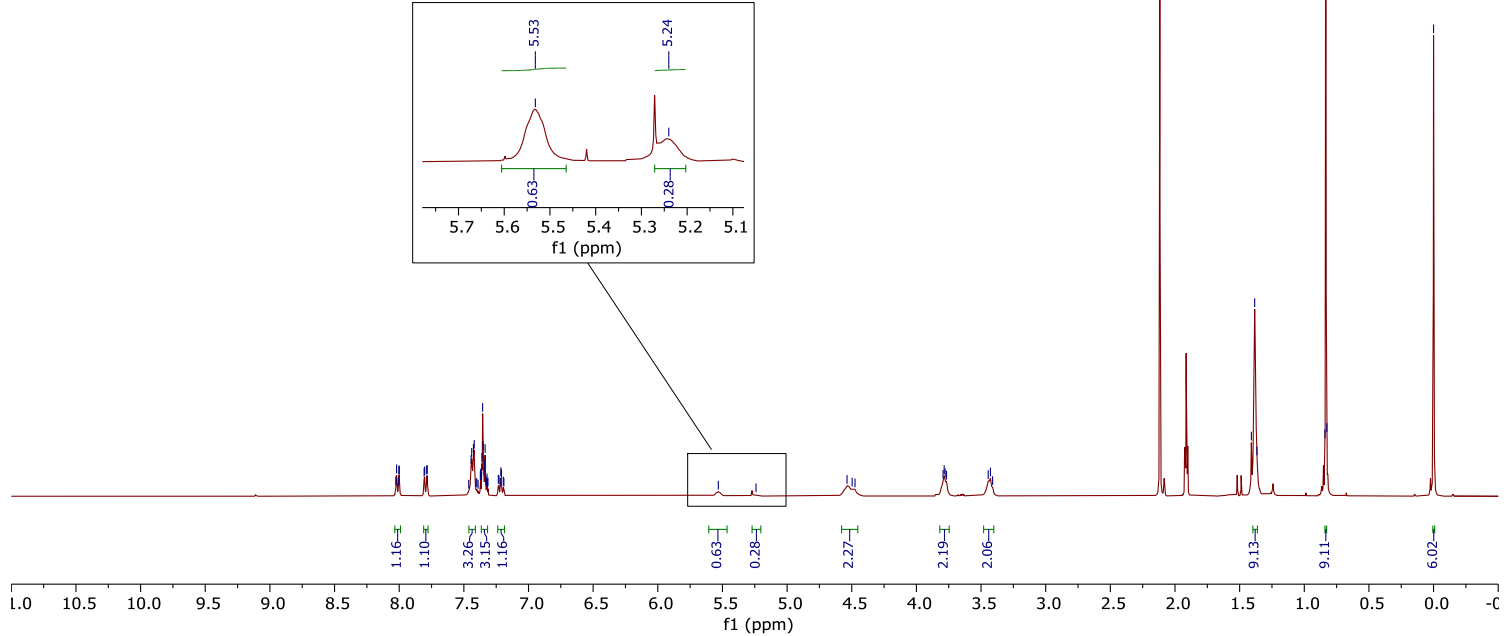

${ }^{13} \mathrm{C}$ NMR $\left(101 \mathrm{MHz}\right.$, Acetonitrile- $\left.d_{3}\right)$

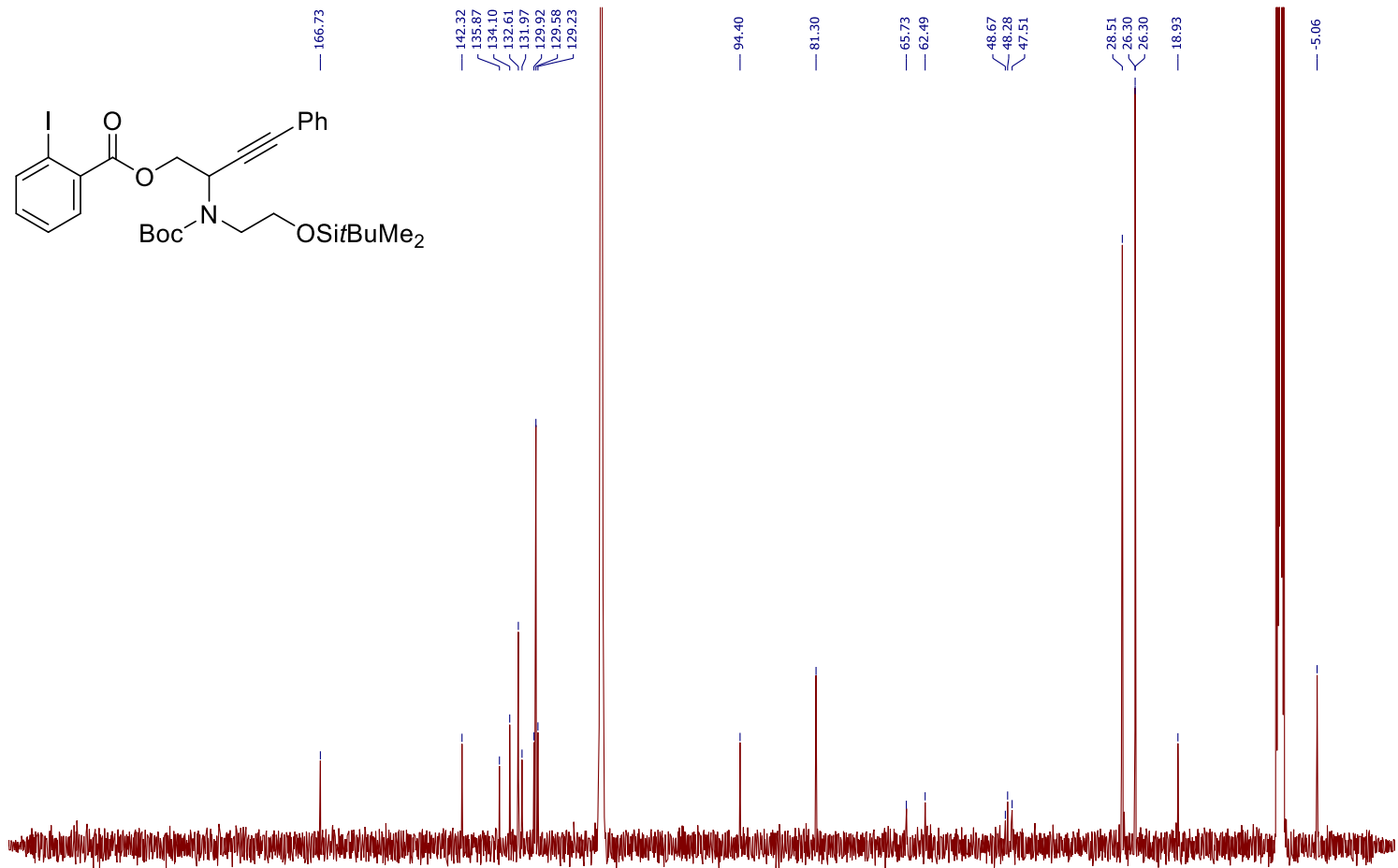

$\begin{array}{llllllllllllllllllllllllllll} & 20 & 210 & 200 & 190 & 180 & 170 & 160 & 150 & 140 & 130 & 120 & 110 & 100 & 90 & 80 & 70 & 60 & 50 & 40 & 30 & 20 & 10 & 0 & -10\end{array}$ 
2-((tert-butoxycarbonyl)(3-ethoxy-3-oxopropyl)amino)-4-phenylbut-3-yn-1-yl iodobenzoate (3h)

${ }^{1} \mathrm{H}$ NMR (400 MHz, Acetonitrile- $\left.d_{3}\right)$

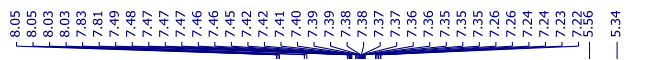

$\overbrace{\mathrm{Boc}^{-} \mathrm{Et}, \mathrm{N}}^{\mathrm{Nh}}$
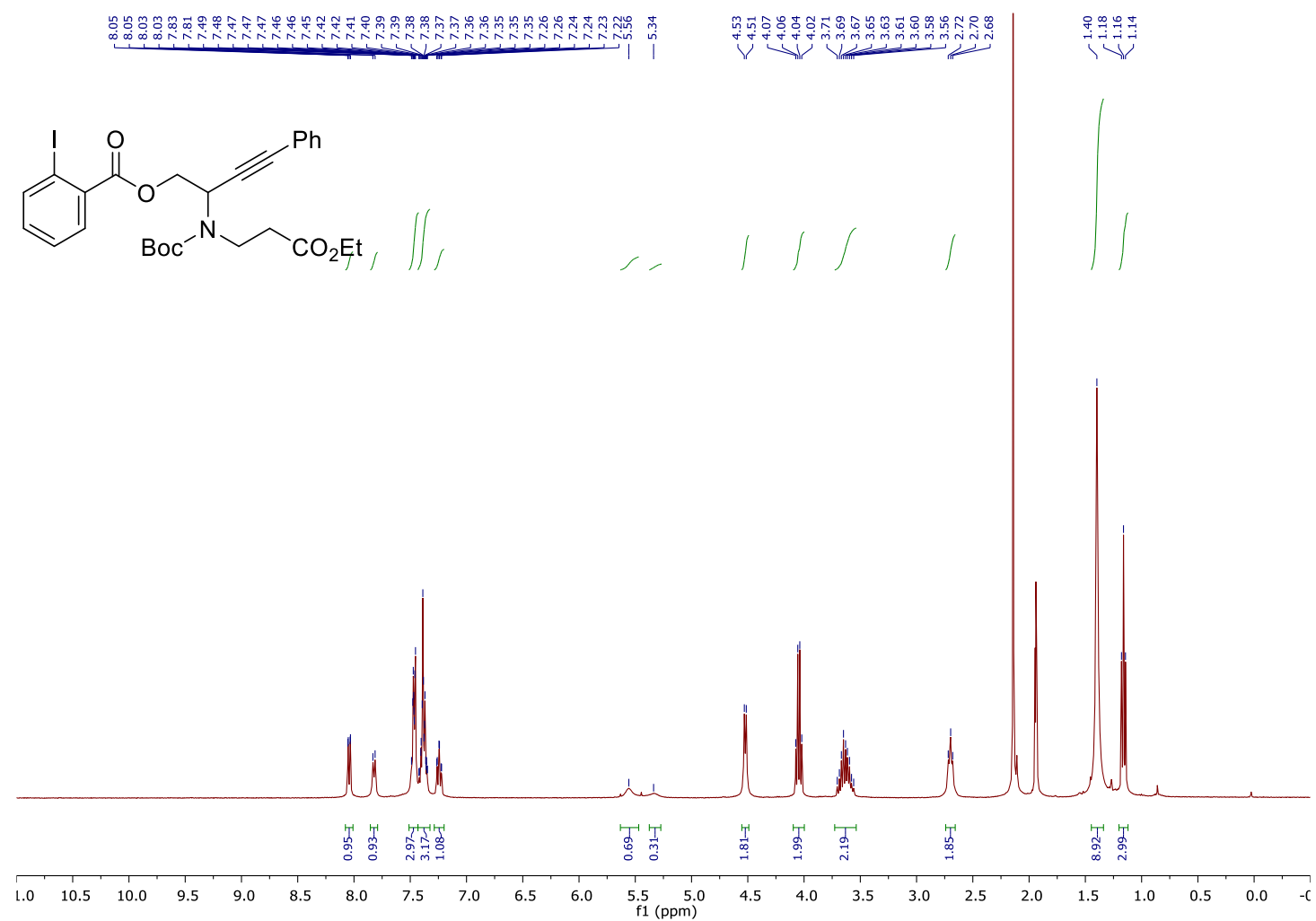

${ }^{13} \mathrm{C}$ NMR $\left(101 \mathrm{MHz}\right.$, Acetonitrile- $\left.d_{3}\right)$

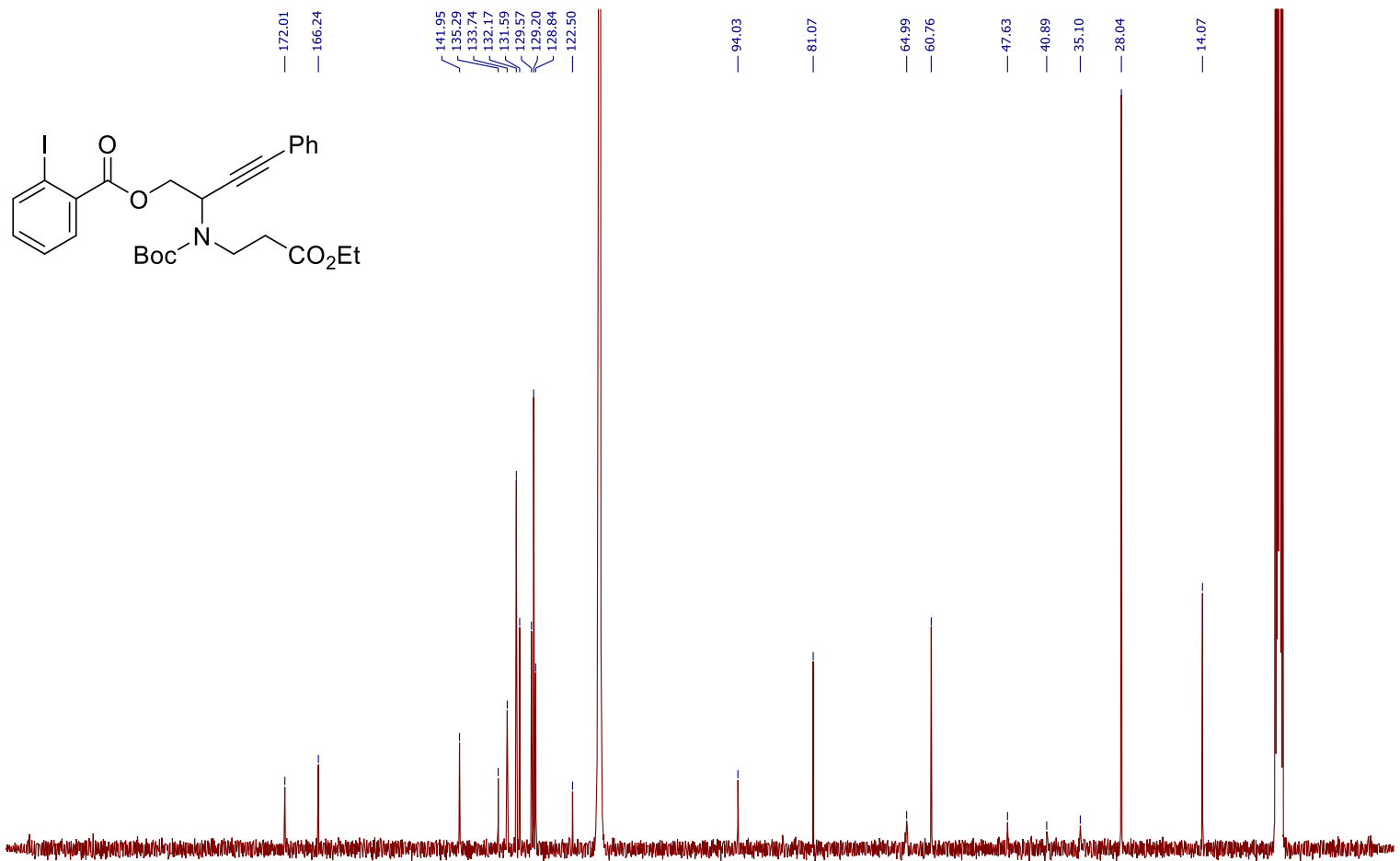

$\begin{array}{lllllllllllllllllllllllllllll}1 & 210 & 200 & 190 & 180 & 170 & 160 & 150 & 140 & 130 & 120 & 110 & 100 & 90 & 80 & 70 & 60 & 50 & 40 & 30 & 20 & 10 & 0 & -10\end{array}$ 
(3i)

${ }^{1} \mathrm{H}$ NMR (400 MHz, Acetonitrile- $\left.d_{3}\right)$

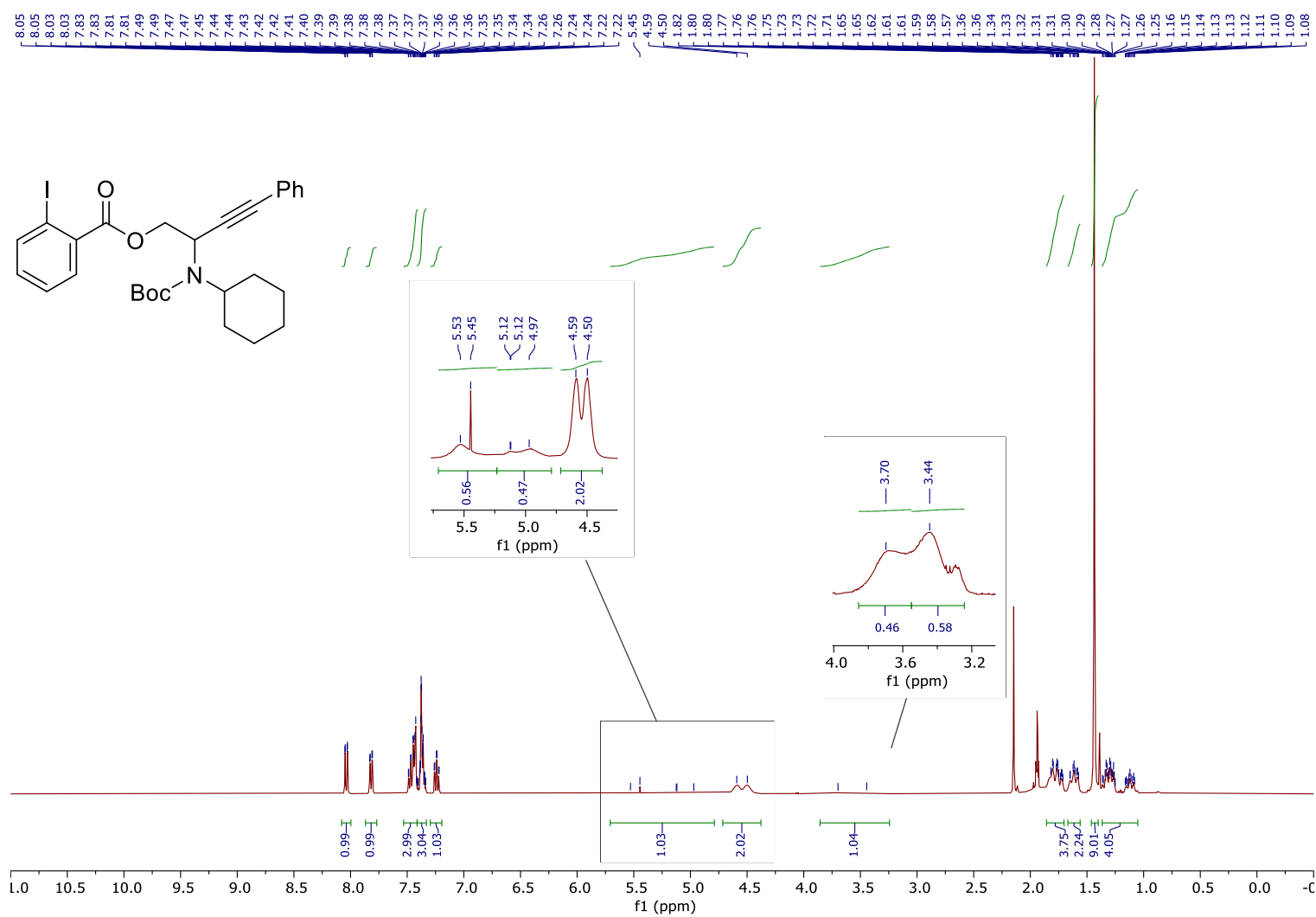

${ }^{13} \mathrm{C}$ NMR (101 MHz, Acetonitrile-d)

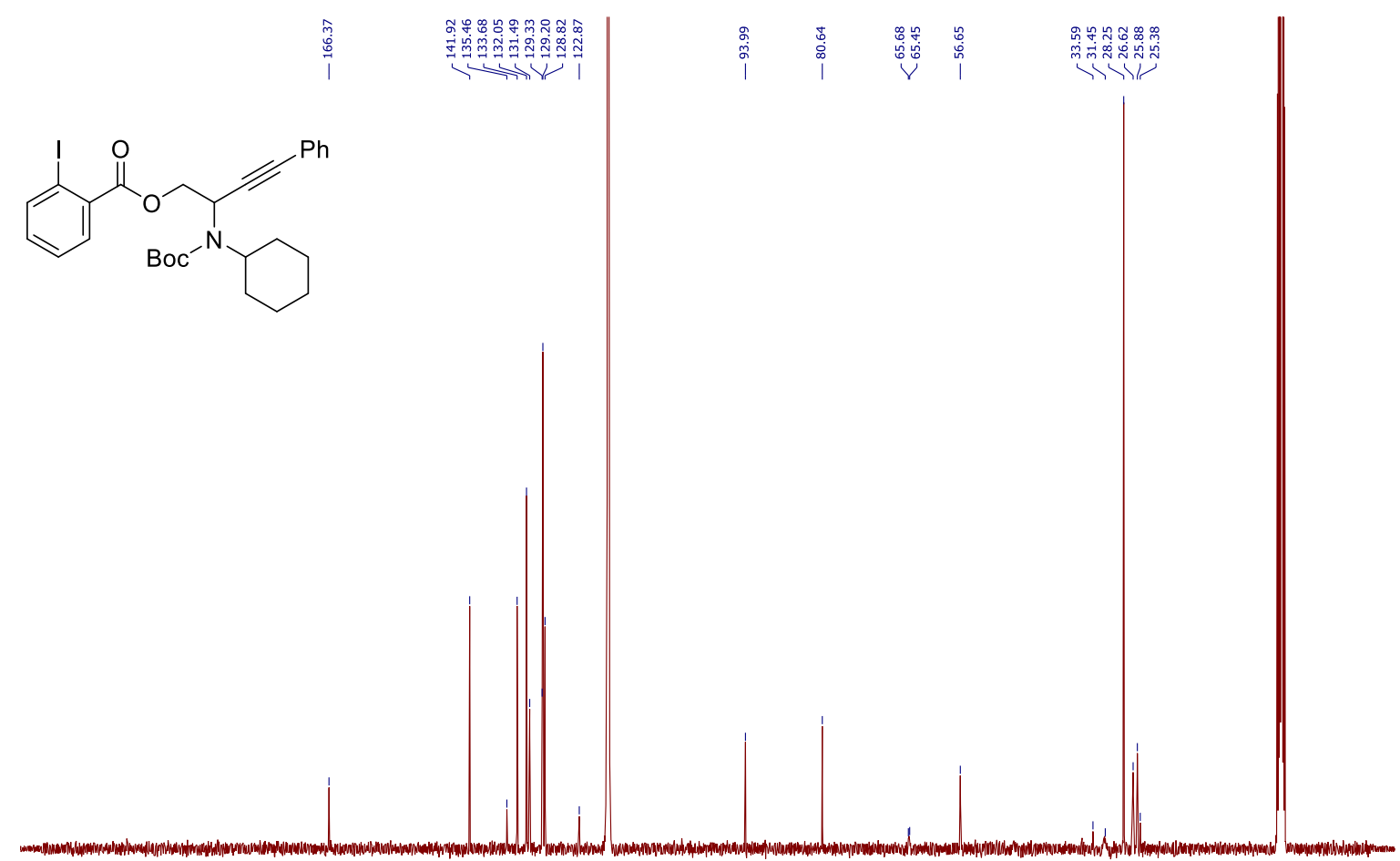

$\begin{array}{llllllllllllllllllllllllllllll}20 & 210 & 200 & 190 & 180 & 170 & 160 & 150 & 140 & 130 & 120 & 110 & 100 & 90 & 80 & 70 & 60 & 50 & 40 & 30 & 20 & 10 & 0 & -10 & \end{array}$ 
2-(2-oxopyrrolidin-1-yl)-4-phenylbut-3-yn-1-yl 2-iodobenzoate (3j) ${ }^{1} \mathrm{H} \mathrm{NMR}\left(400 \mathrm{MHz}\right.$, Acetonitrile- $\left.d_{3}\right)$

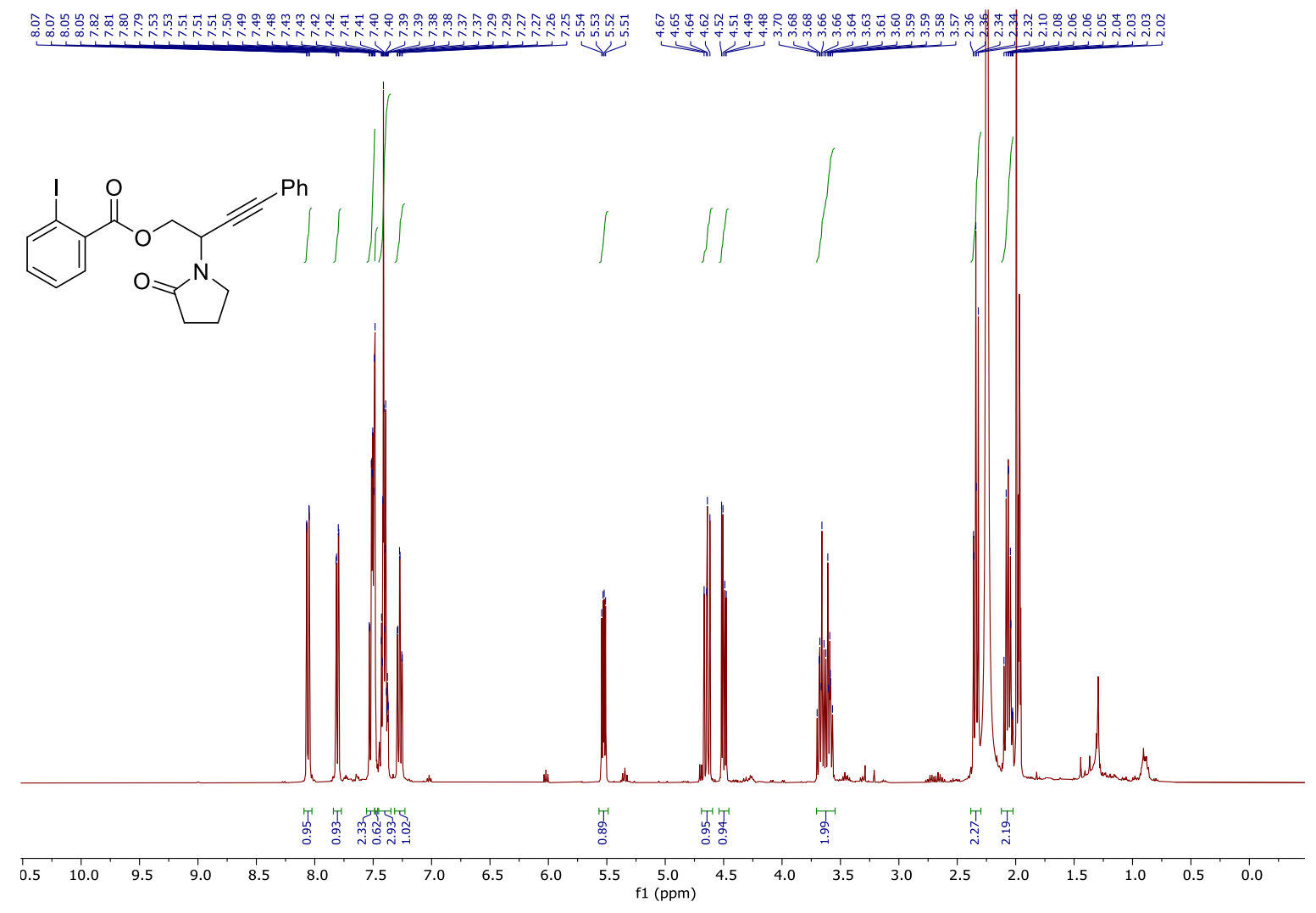

${ }^{13} \mathrm{C}$ NMR $\left(101 \mathrm{MHz}\right.$, Acetonitrile- $\left.d_{3}\right)$

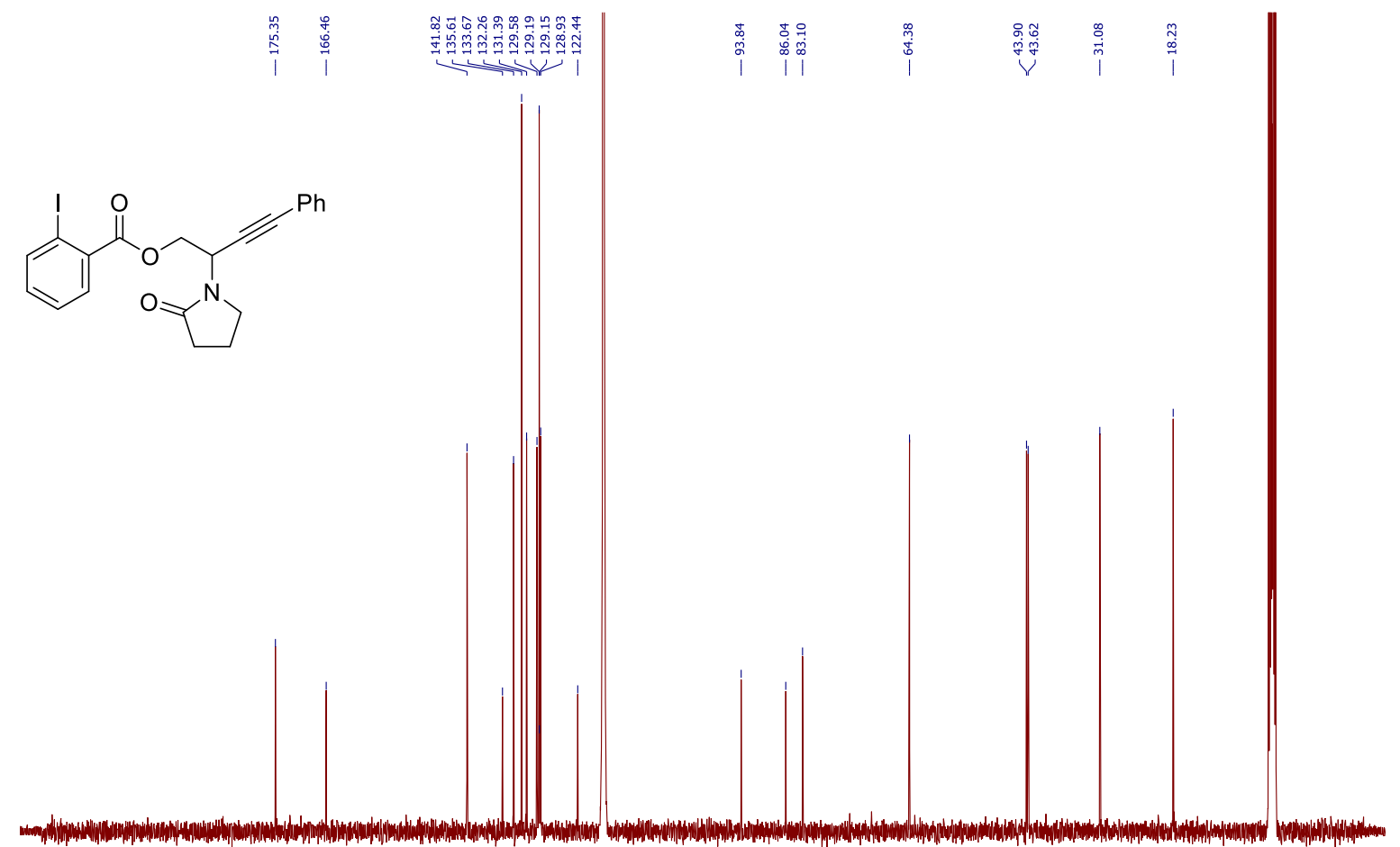

$\begin{array}{llllllllllllllllllllllllllll}1 & 210 & 200 & 190 & 180 & 170 & 160 & 150 & 140 & 130 & 120 & 110 & 100 & 90 & 80 & 70 & 60 & 50 & 40 & 30 & 20 & 10 & 0 & -10\end{array}$ 
3-(2-oxooxazolidin-3-yl)-1-phenyloct-1-yn-4-yl

${ }^{1} \mathrm{H}$ NMR (400 MHz, Chloroform-d)

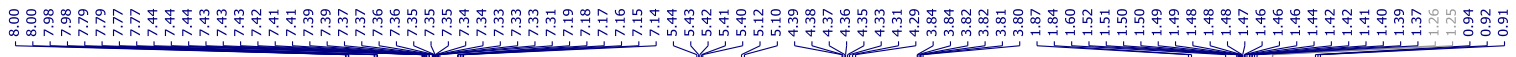<smiles>CCCCC(OC(=O)c1ccccc1I)C(C#Cc1ccccc1)N1CCOC1=O</smiles>
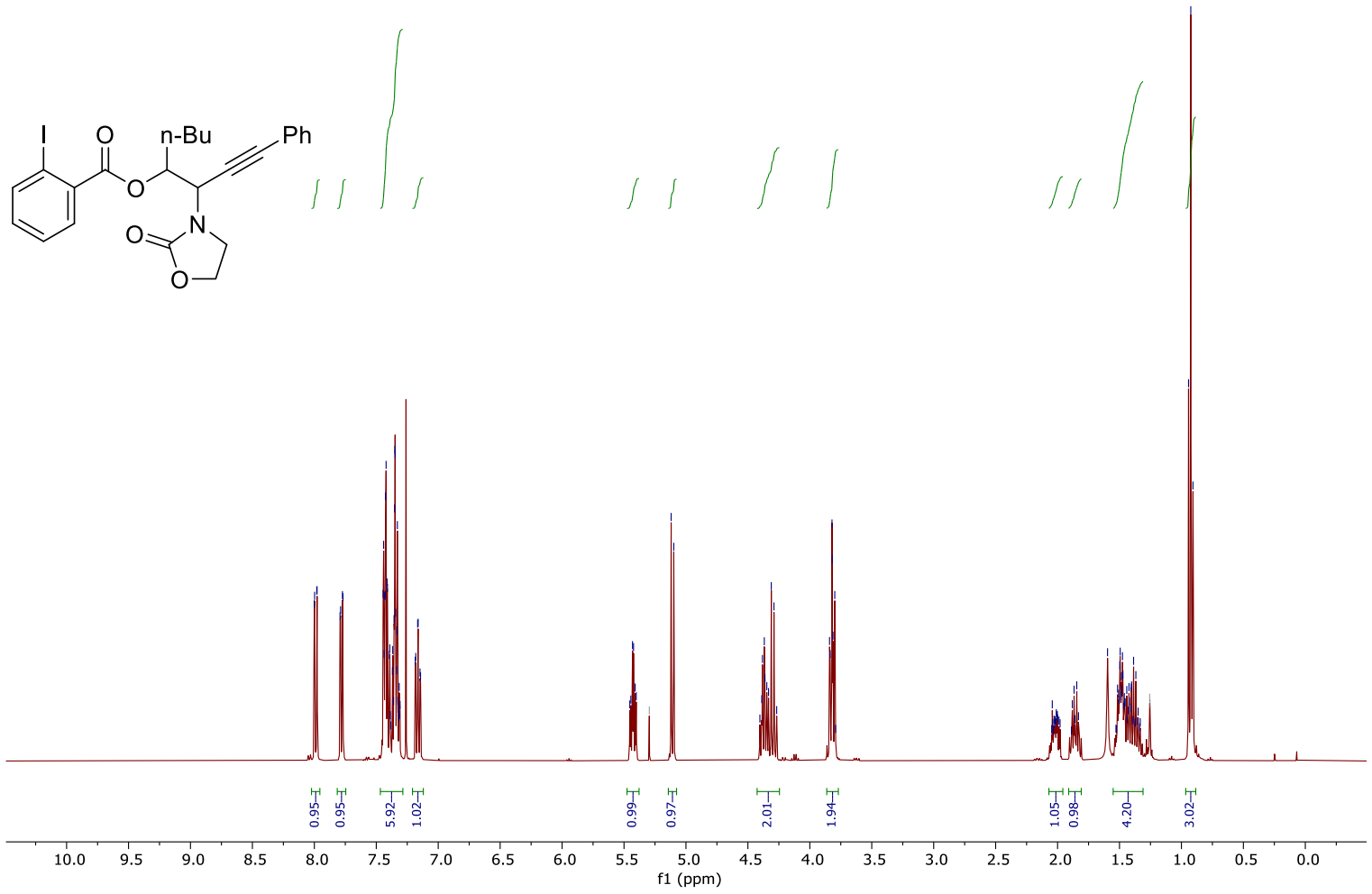

${ }^{13} \mathrm{C}$ NMR $(101 \mathrm{MHz}$, Chloroform- $d)$

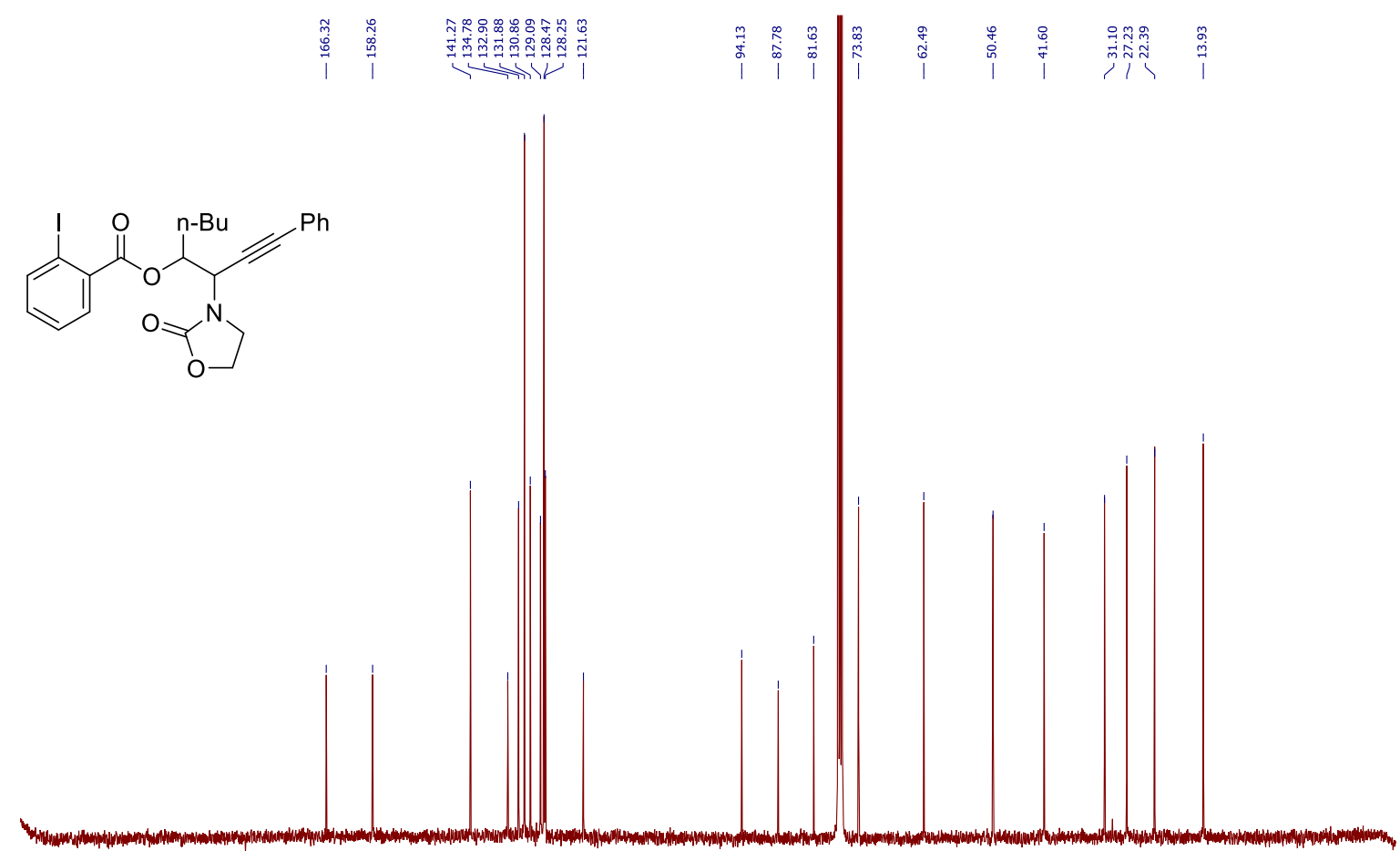

$\begin{array}{lllllllllllllllllllllll}210 & 200 & 190 & 180 & 170 & 160 & 150 & 140 & 130 & 120 & 110 & 100 & 90 & 80 & 70 & 60 & 50 & 40 & 30 & 20 & 10 & 0 & -10\end{array}$ 
3-(2-oxooxazolidin-3-yl)-1-phenyloct-1-yn-4-yl diastereoisomer) (traces of DCM)

${ }^{1} \mathrm{H}$ NMR (400 MHz, Chloroform-d)

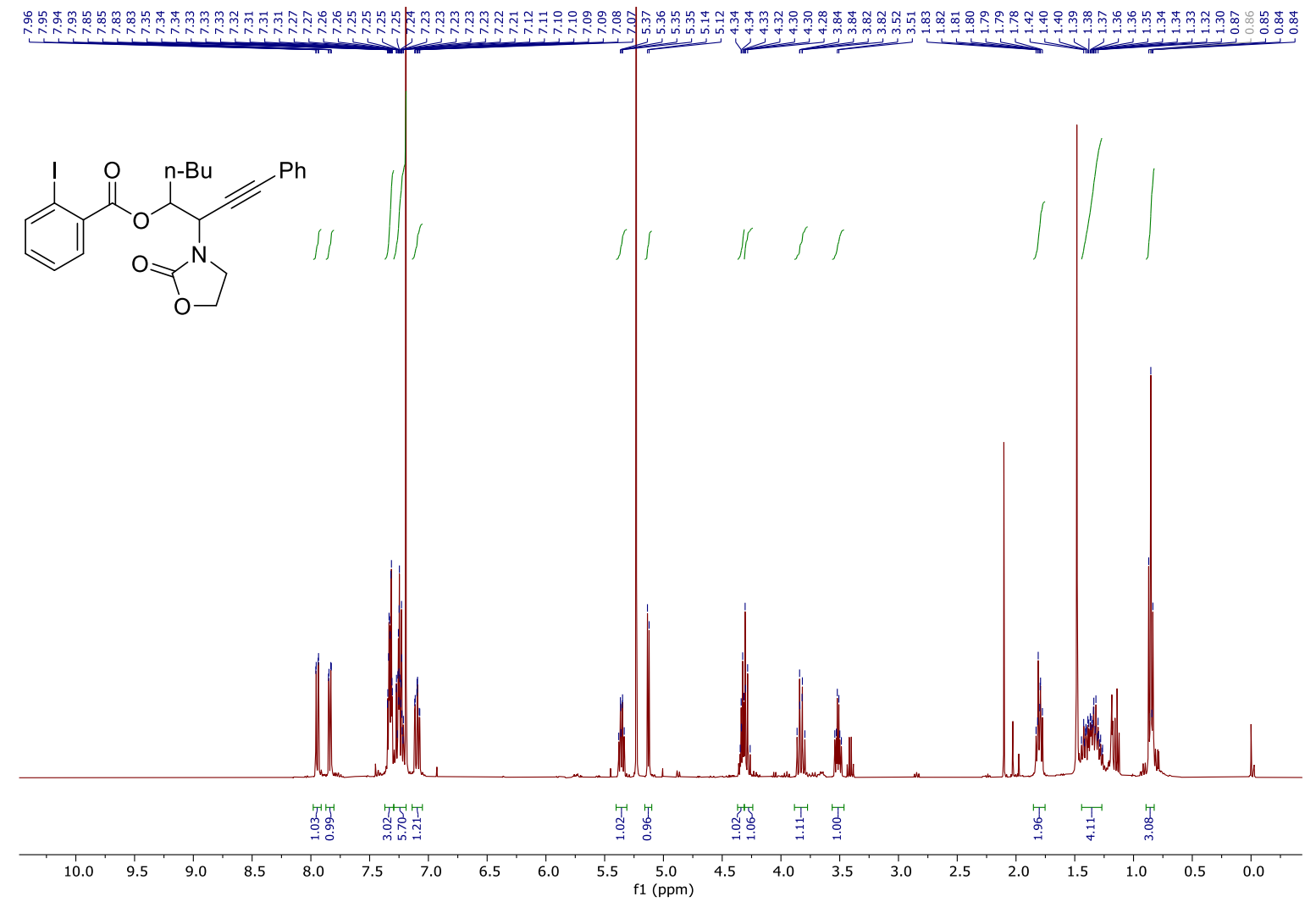

${ }^{13} \mathrm{C}$ NMR (101 MHz, Chloroform-d)

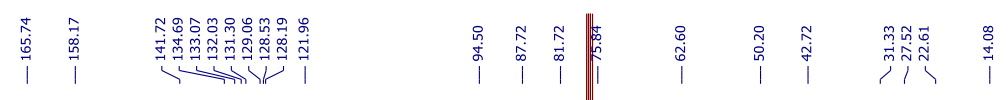<smiles></smiles>
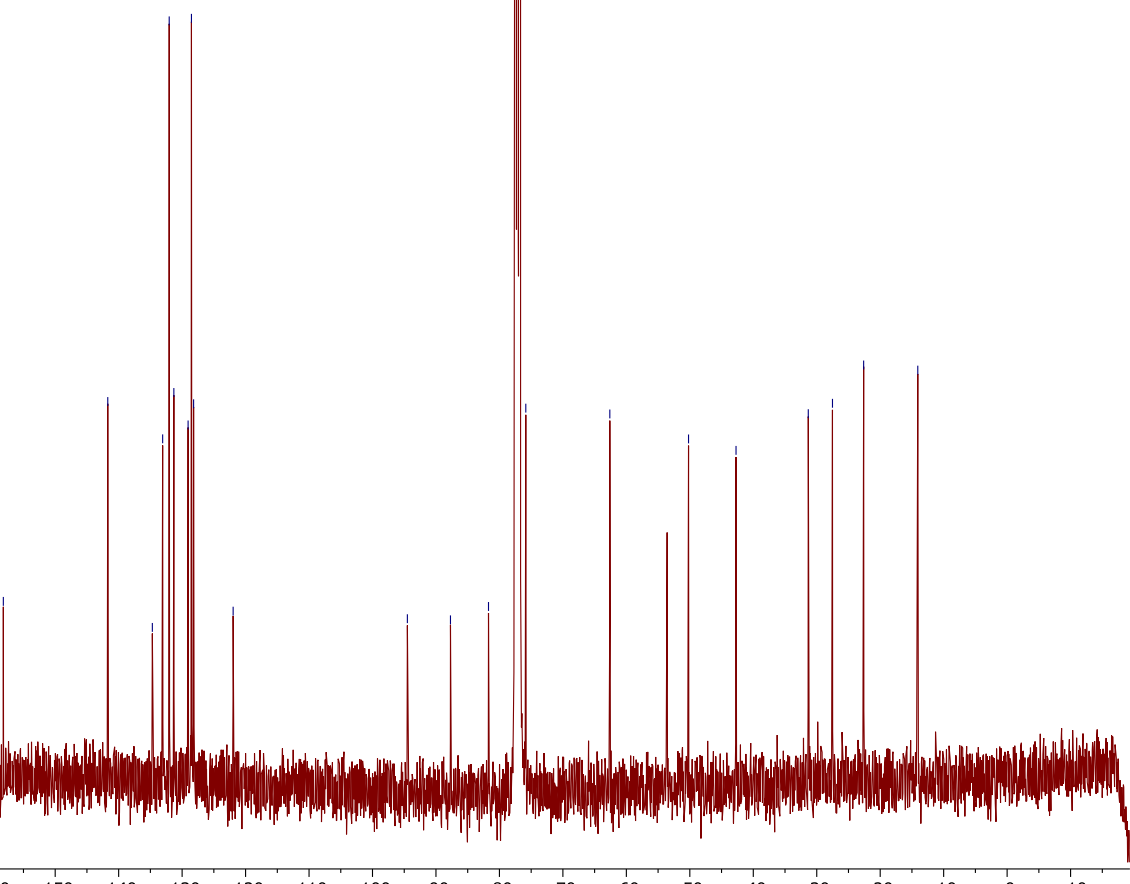

$\begin{array}{lllllllllll}210 & 200 & 190 & 180 & 170 & 160 & 150 & 140 & 130 & 120 & 110 \begin{array}{c}100 \\ \mathrm{f} 1(\mathrm{ppm})\end{array}\end{array}$ 
2-butoxy-4-phenylbut-3-yn-1-yl 2-iodobenzoate (10a) ${ }^{1} \mathrm{H}$ NMR (400 MHz, chloroform-d)

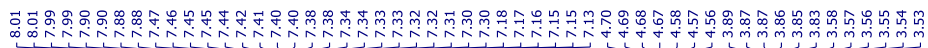<smiles>C#CC#CC</smiles>
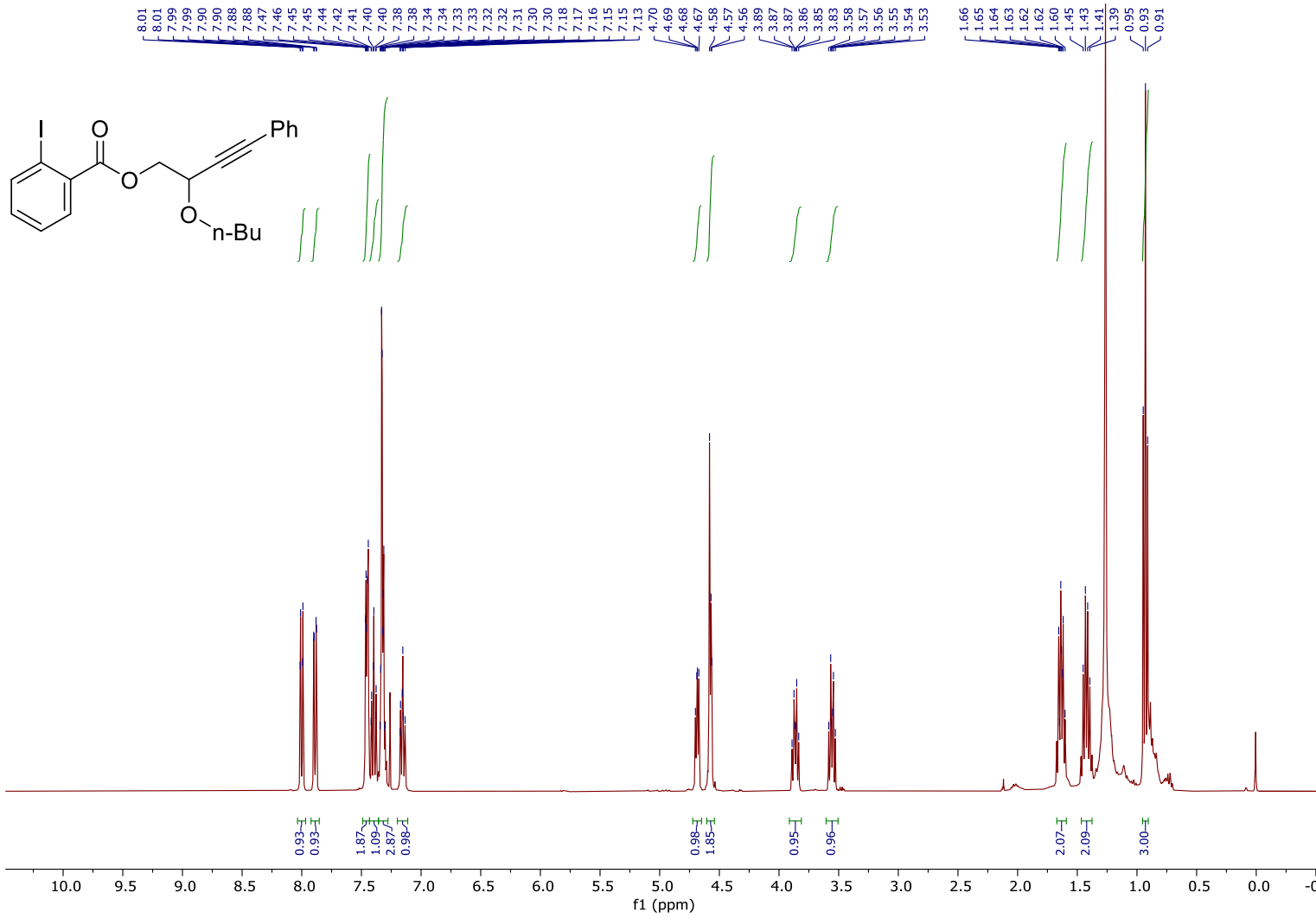

${ }^{13} \mathrm{C}$ NMR (400 MHz, chloroform-d)
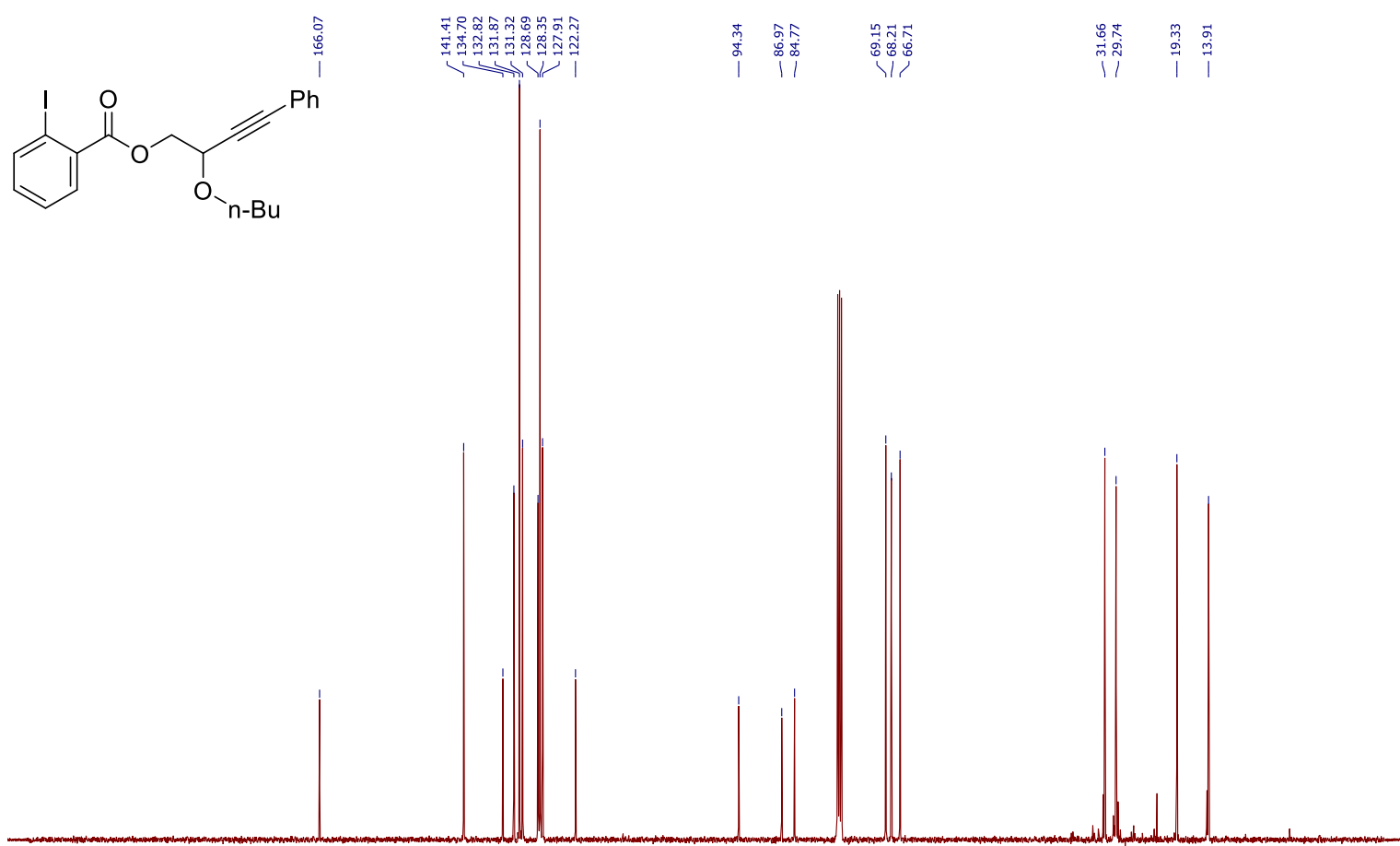

$\begin{array}{llllllllllll}210 & 200 & 190 & 180 & 170 & 160 & 150 & 140 & 130 & 120 & 110 & 100\end{array}$ 
2-benzyloxy-4-phenylbut-1-yn-4-yl 2-iodobenzoate (10b) ${ }^{1} \mathrm{H}$ NMR (400 MHz, Acetonitrile- $\left.d_{3}\right)$

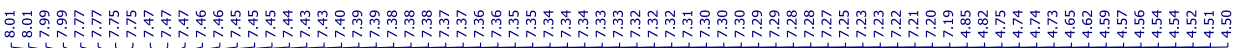<smiles>O=C(OCC(C#Cc1ccccc1)OCc1ccccc1)c1ccccc1I</smiles>

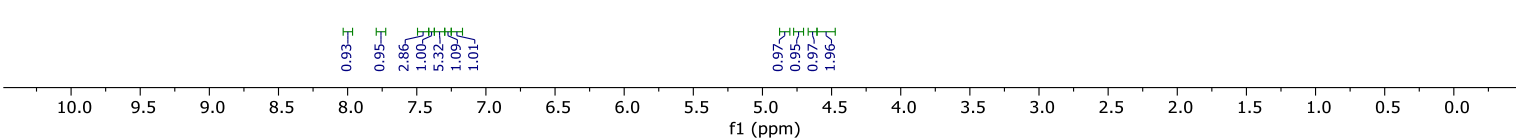

${ }^{13} \mathrm{C}$ NMR (400 MHz, Acetonitrile- $\left.d_{3}\right)$

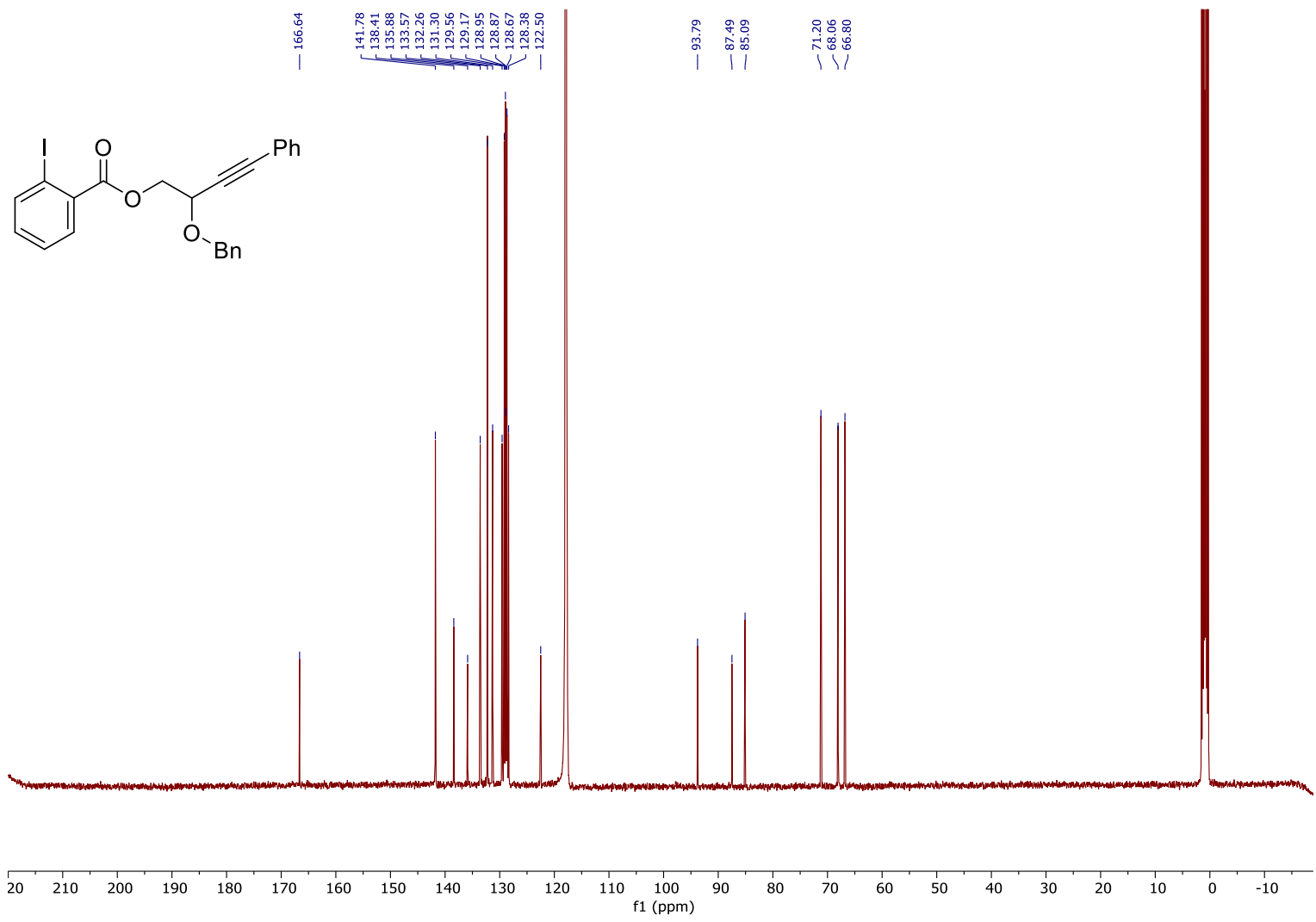


2-(allyloxy)-4-phenylbut-3-yn-1-yl 2-iodobenzoate (10c) ${ }^{1} \mathrm{H}$ NMR $\left(400 \mathrm{MHz}\right.$, Acetonitrile- $\left.d_{3}\right)$

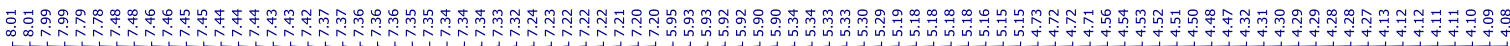

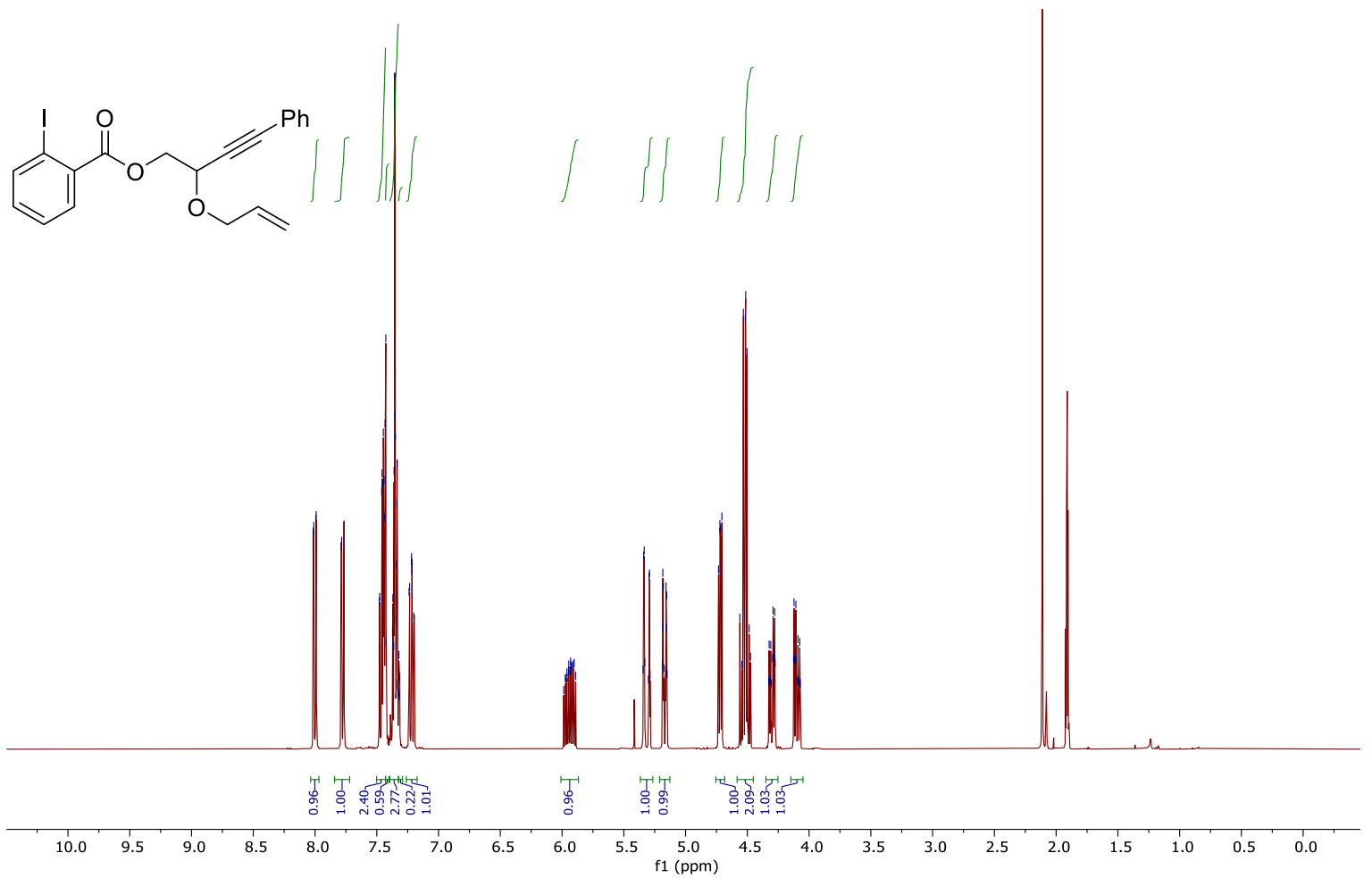

${ }^{13} \mathrm{C}$ NMR (400 MHz, Acetonitrile- $\left.d_{3}\right)$

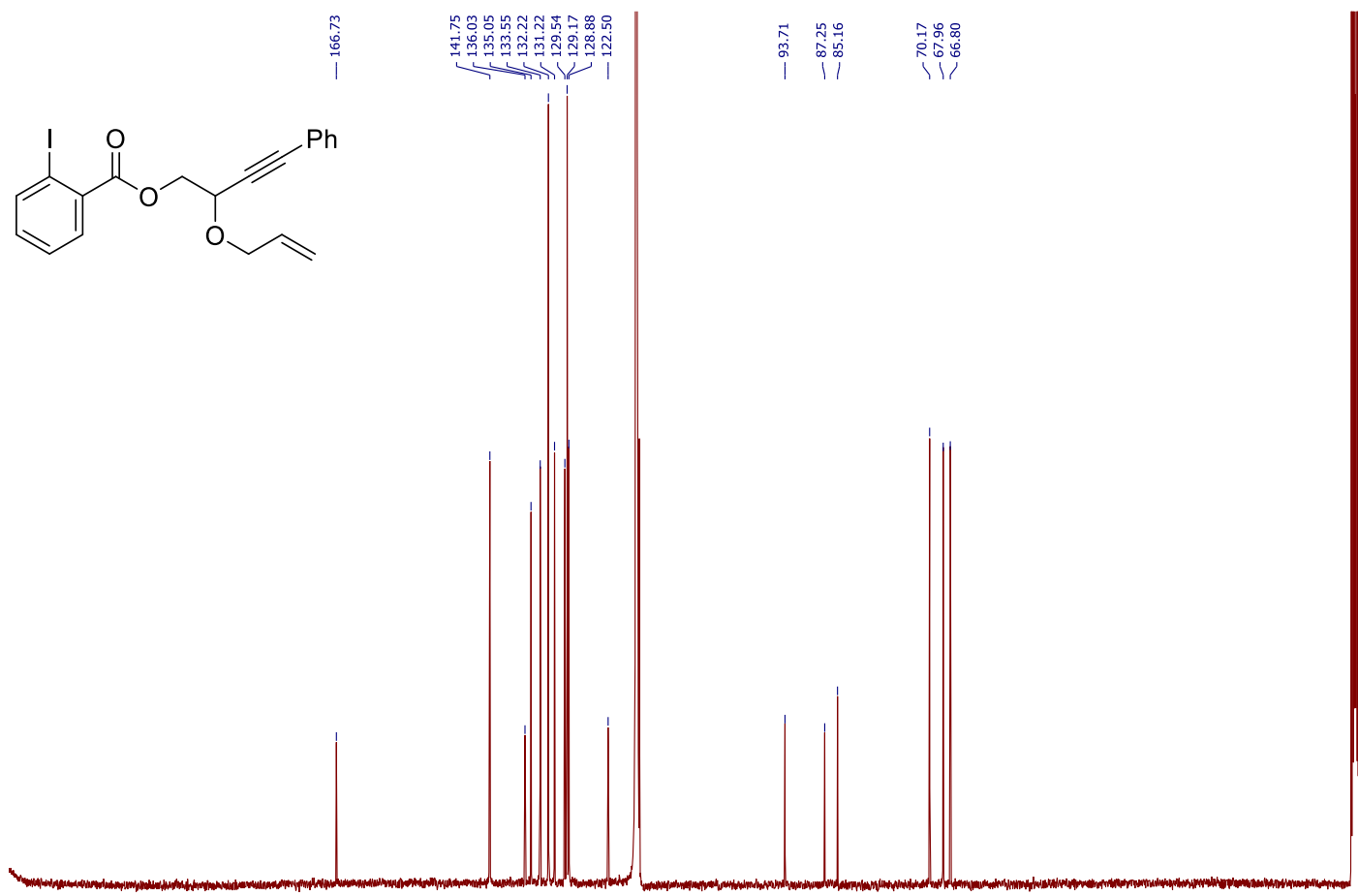

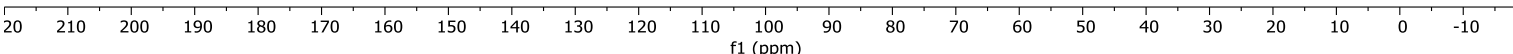


2-(2-chloroethoxy)-4-phenylbut-3-yn-1-yl 2-iodobenzoate (10d) ${ }^{1} \mathrm{H}$ NMR (400 MHz, chloroform-d)

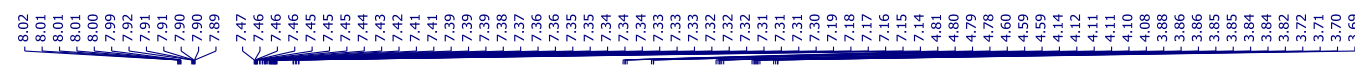<smiles>O=C(OCC(C#Cc1ccccc1)OCCCl)c1ccccc1I</smiles>
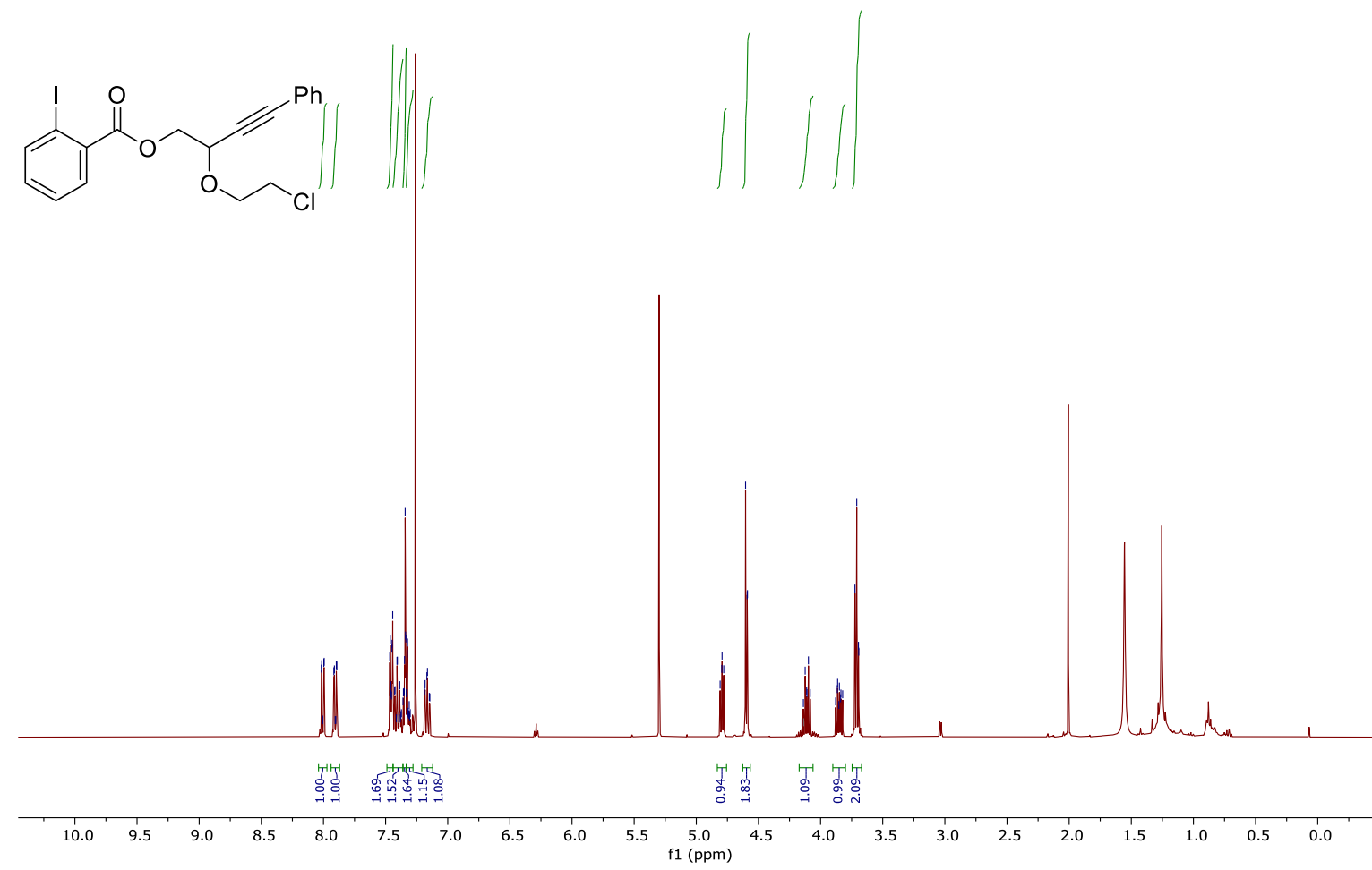

${ }^{13} \mathrm{C}$ NMR (400 MHz, chloroform- $d$ )<smiles>O=C(OCC(C#Cc1ccccc1)OCCCl)c1ccccc1I</smiles>

t)

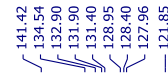

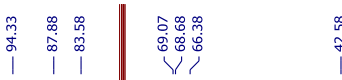
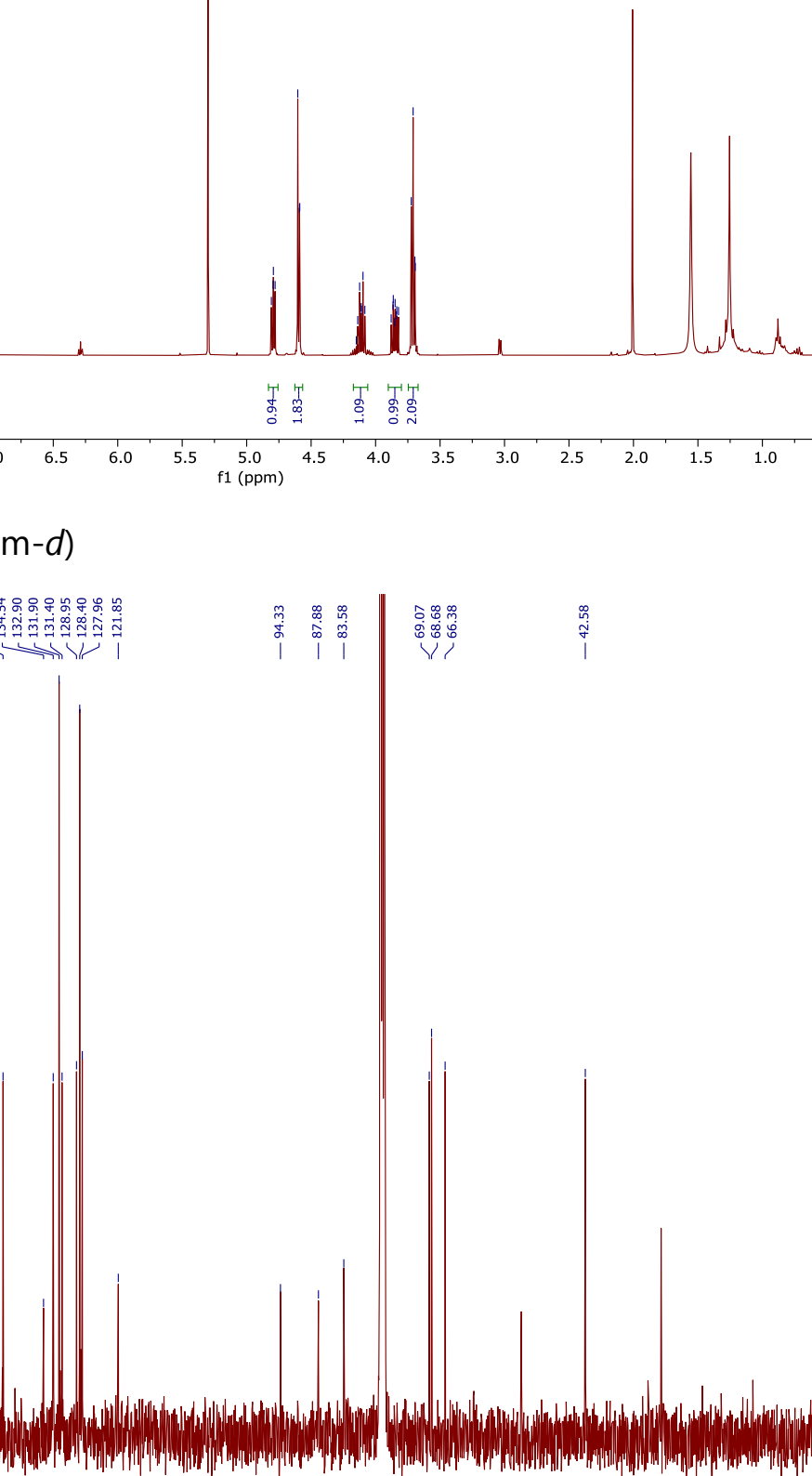
2-cyclohexyloxy-4-phenylbut-1-yn-4-yl 2-iodobenzoate (10e) ${ }^{1} \mathrm{H}$ NMR (400 MHz, chloroform-d)

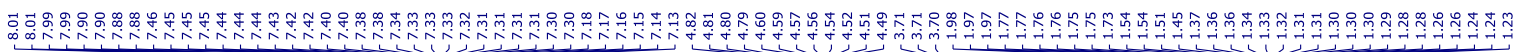

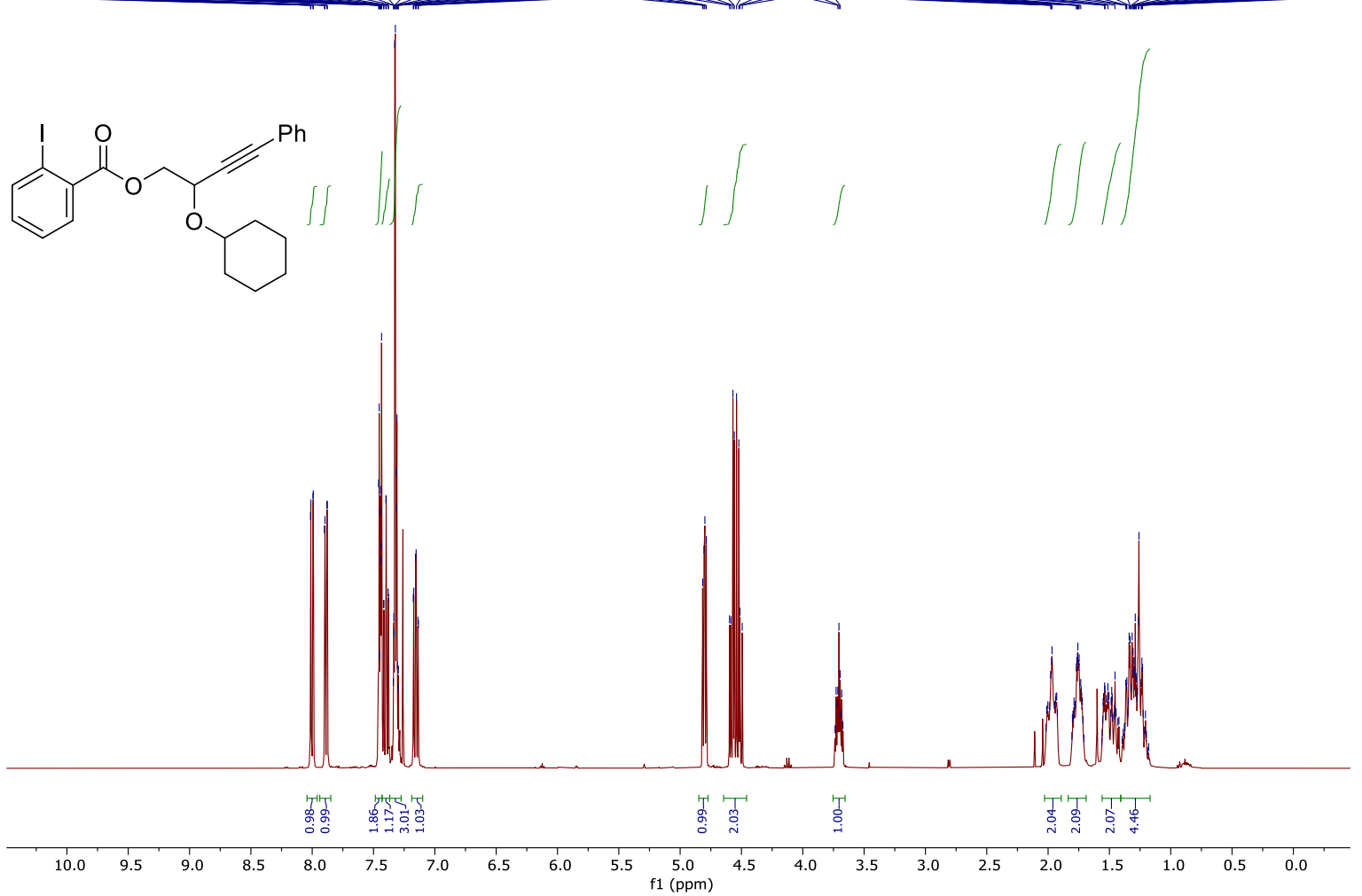

${ }^{13} \mathrm{C}$ NMR $(400 \mathrm{MHz}$, chloroform- $d$ )

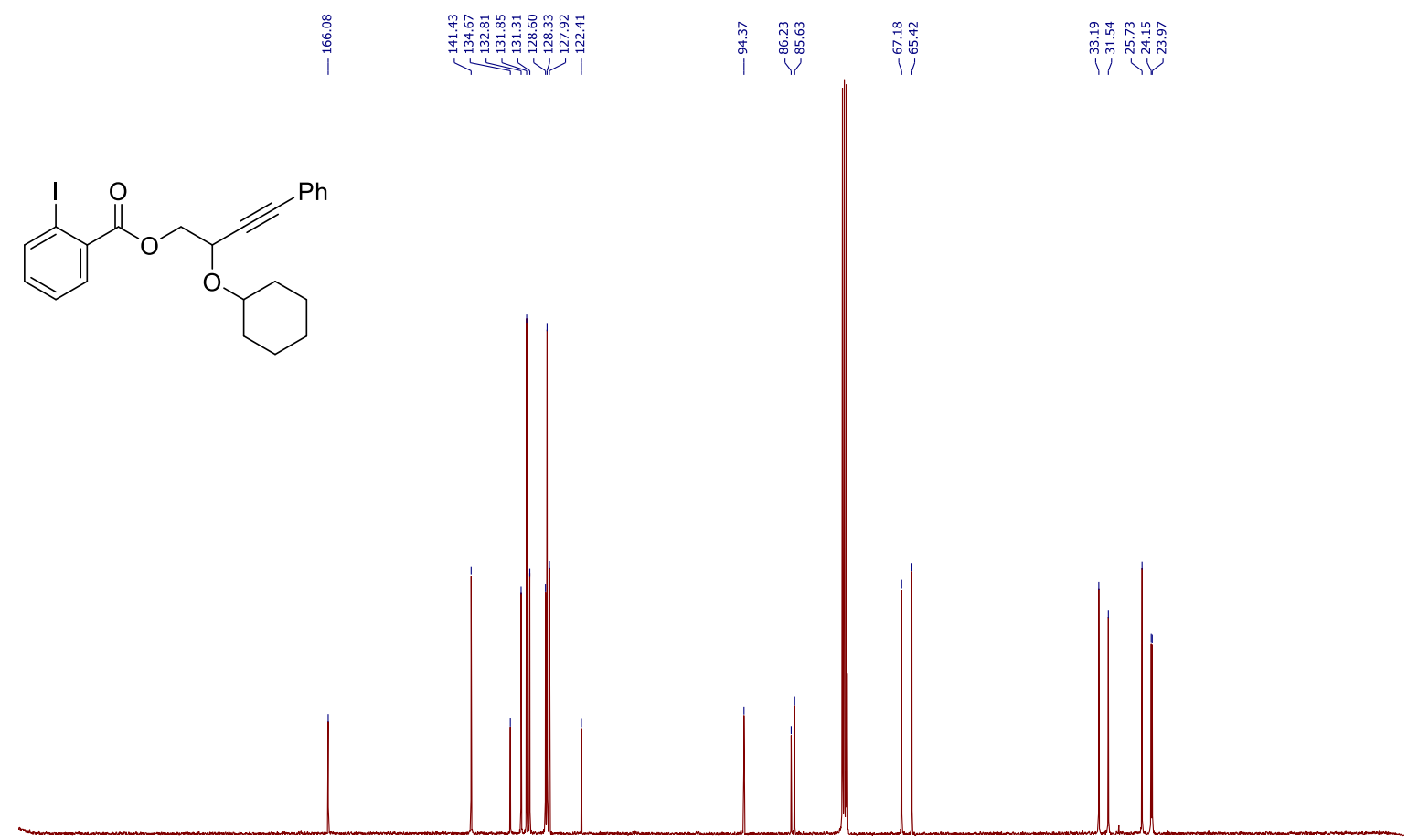

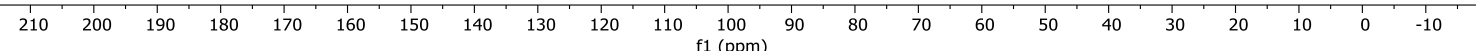


2-ethoxyoxy-2-methyl-4-phenylbut-1-yn-4-yl 2-iodobenzoate (10f) ${ }^{1} \mathrm{H}$ NMR (400 MHz, chloroform-d)

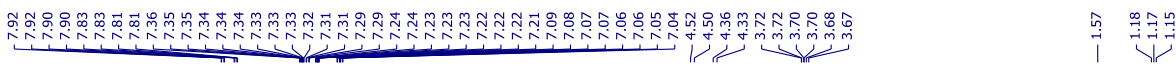<smiles>CCOC(C)(C#Cc1ccccc1)COC(=O)c1ccccc1I</smiles>
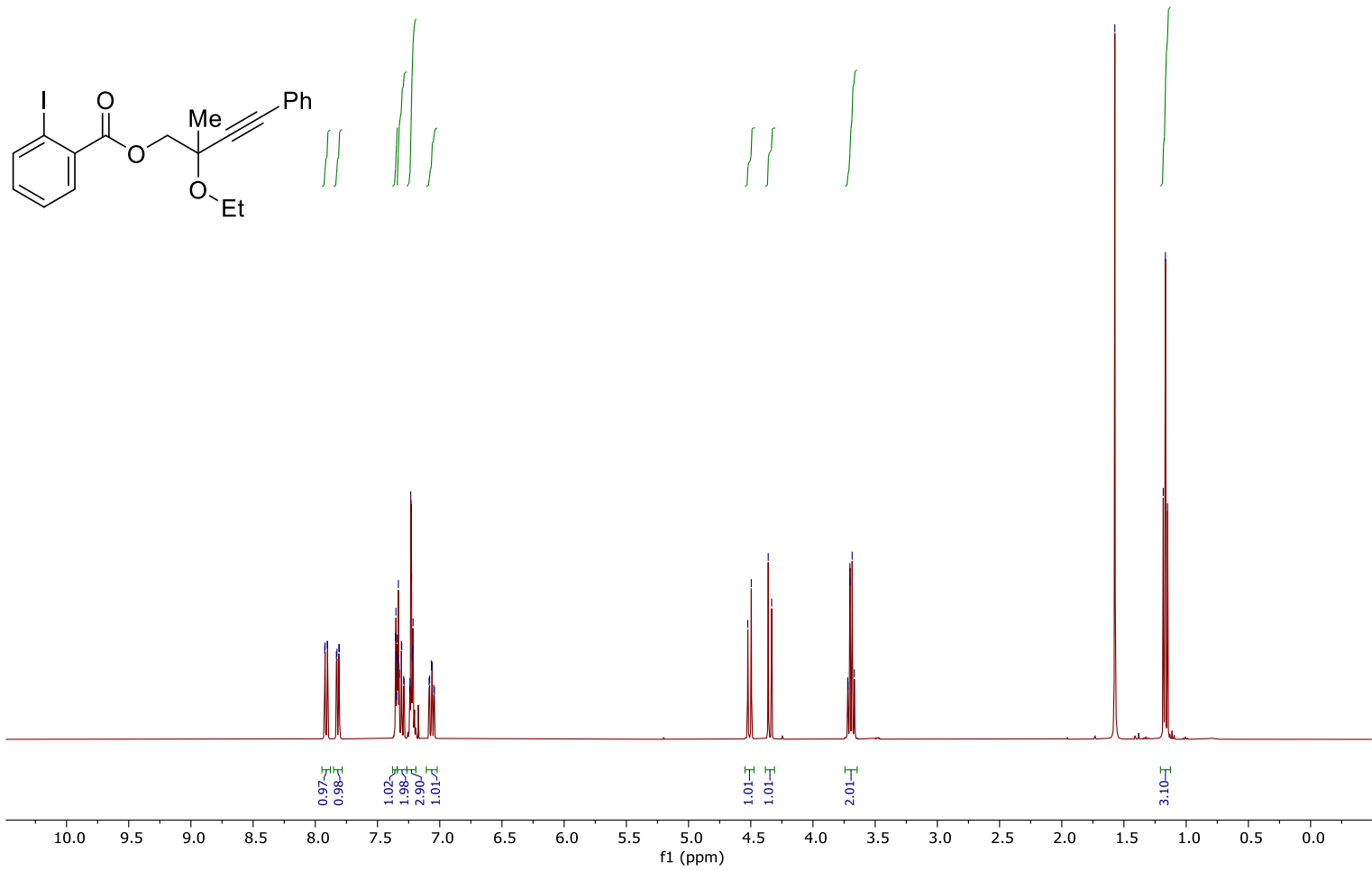

${ }^{13} \mathrm{C}$ NMR (400 MHz, chloroform-d)

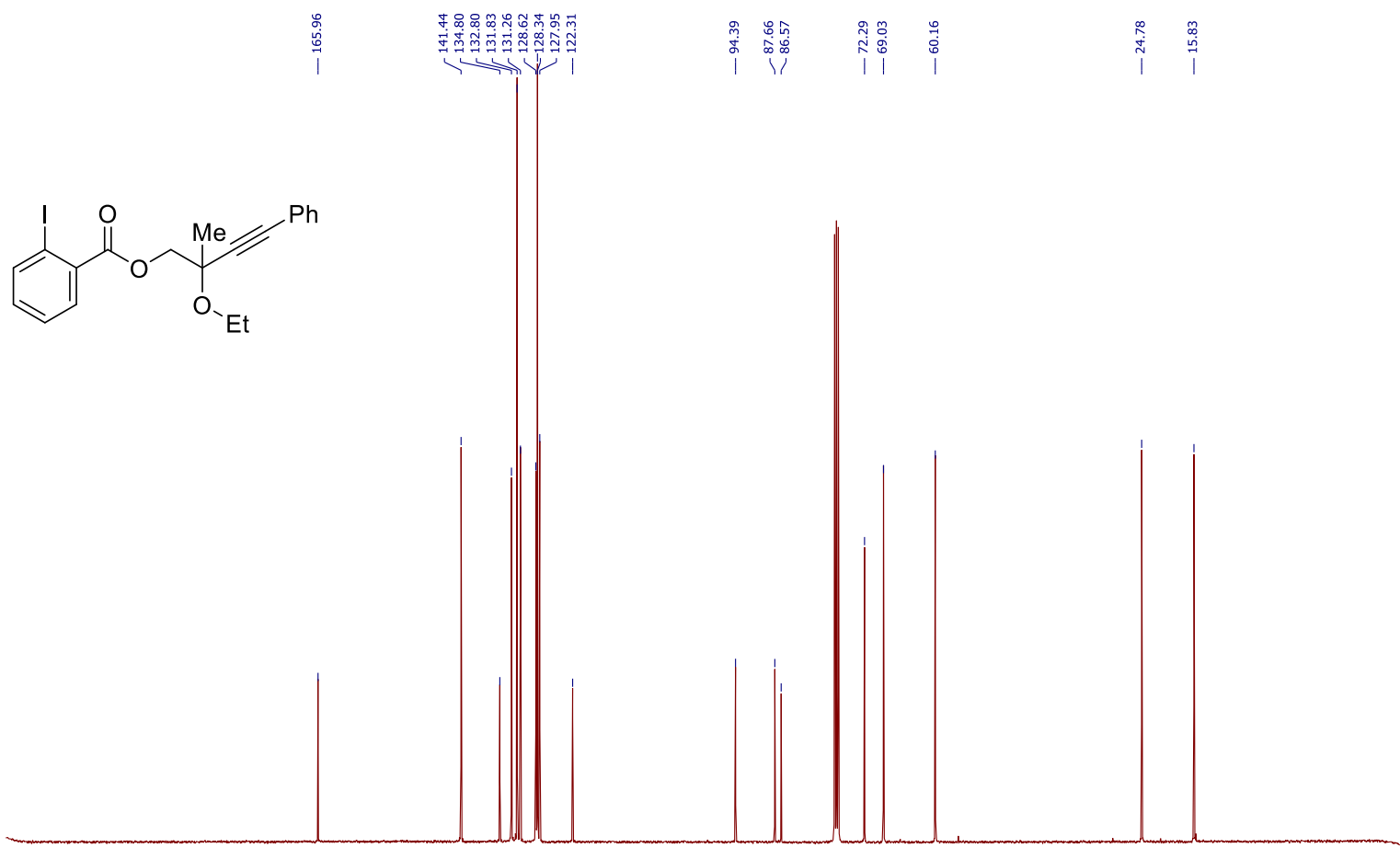

$\begin{array}{lllllllllllllllllllllllll}210 & 200 & 190 & 180 & 170 & 160 & 150 & 140 & 130 & 120 & 110 & 100 & 90 & 80 & 70 & 60 & 50 & 40 & 30 & 20 & 10 & 0 & -10\end{array}$ 
1-(benzyloxy)-2-(phenylethynyl)hexyl 2-iodobenzoate (10ga)

${ }^{1} \mathrm{H}$ NMR $(400 \mathrm{MHz}$, chloroform-d)

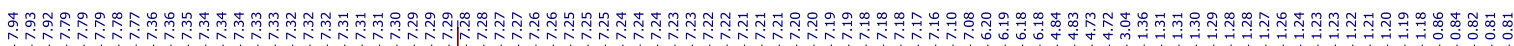<smiles>CC#CC([18OH])C(O[14CH3])OC(=O)c1ccccc1C</smiles>

st
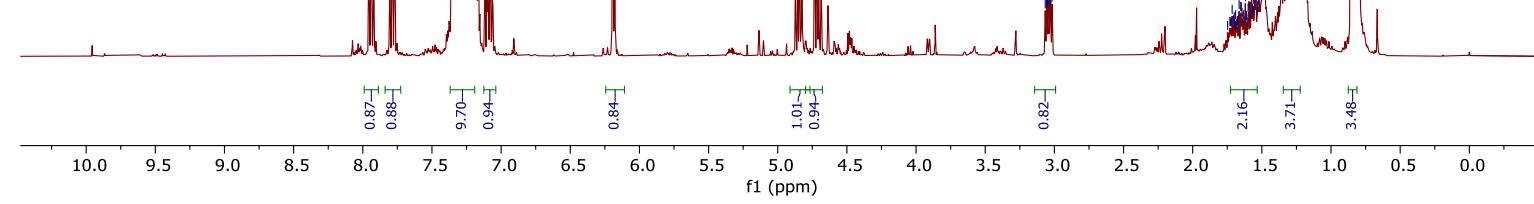

${ }^{13} \mathrm{C}$ NMR $(400 \mathrm{MHz}$, chloroform- $d$ )

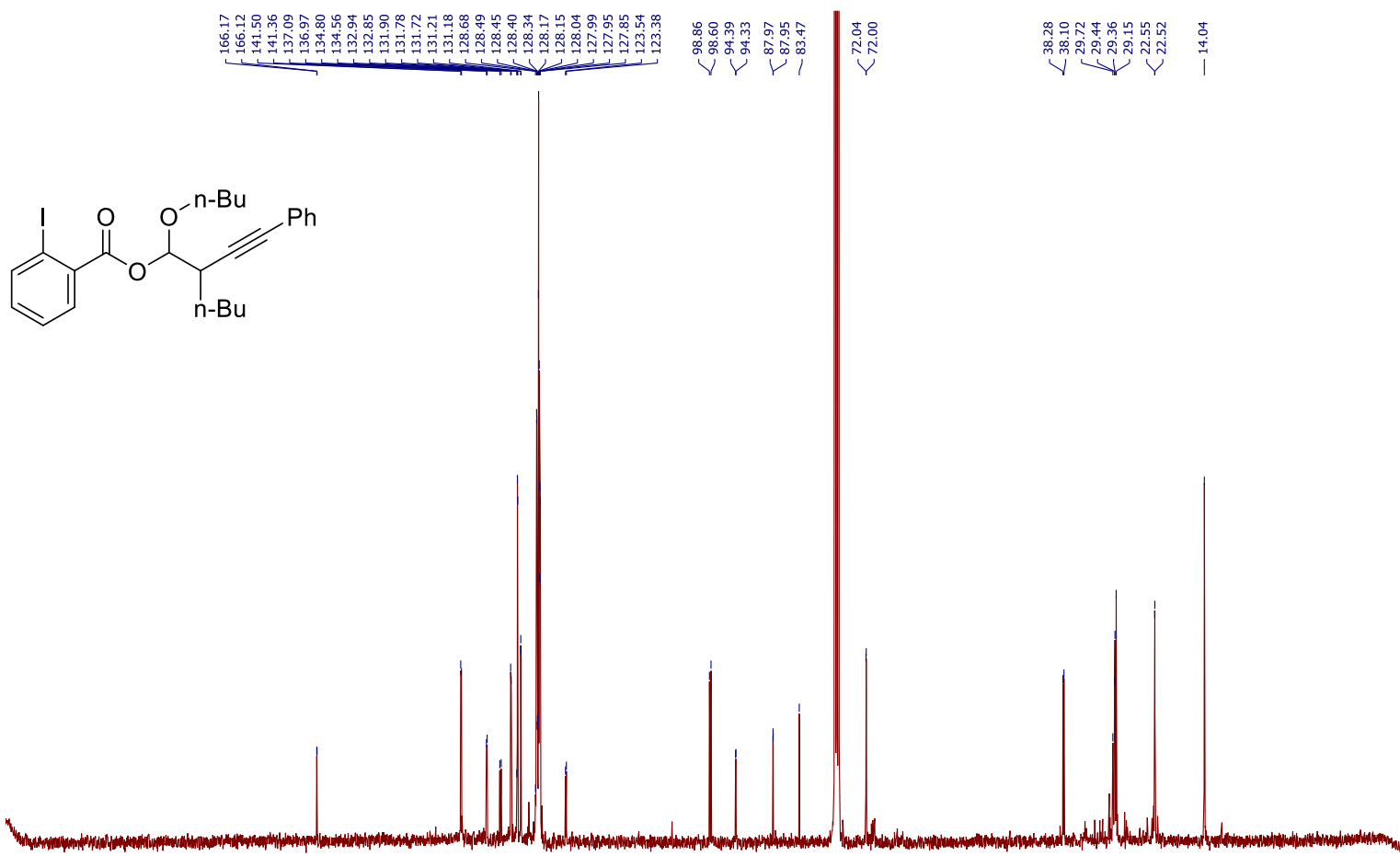

$\begin{array}{lllllllllllllllllllllll}1 & 200 & 190 & 180 & 170 & 160 & 150 & 140 & 130 & 120 & 110 & 100 & 90 & 80 & 70 & 60 & 50 & 40 & 30 & 20 & 10 & 0 & -10\end{array}$ 
3-(benzyloxy)-1-phenyloct-1-yn-4-yl 2-iodobenzoate (10gb)

${ }^{1} \mathrm{H}$ NMR $(400 \mathrm{MHz}$, chloroform-d)

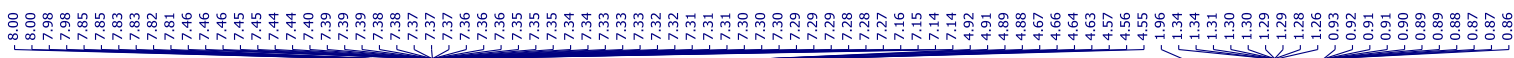

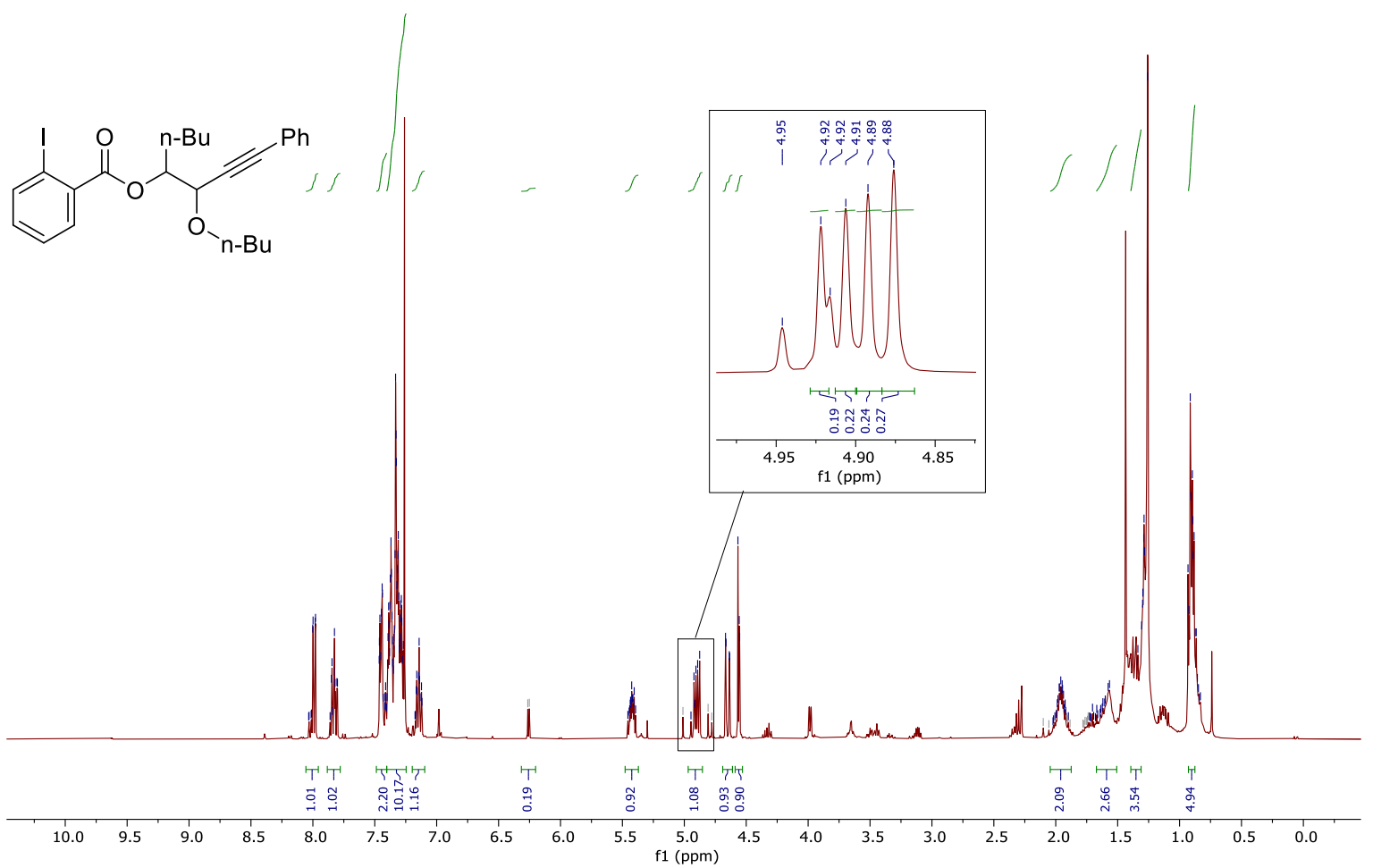

${ }^{13} \mathrm{C}$ NMR $(400 \mathrm{MHz}$, chloroform- $d)$

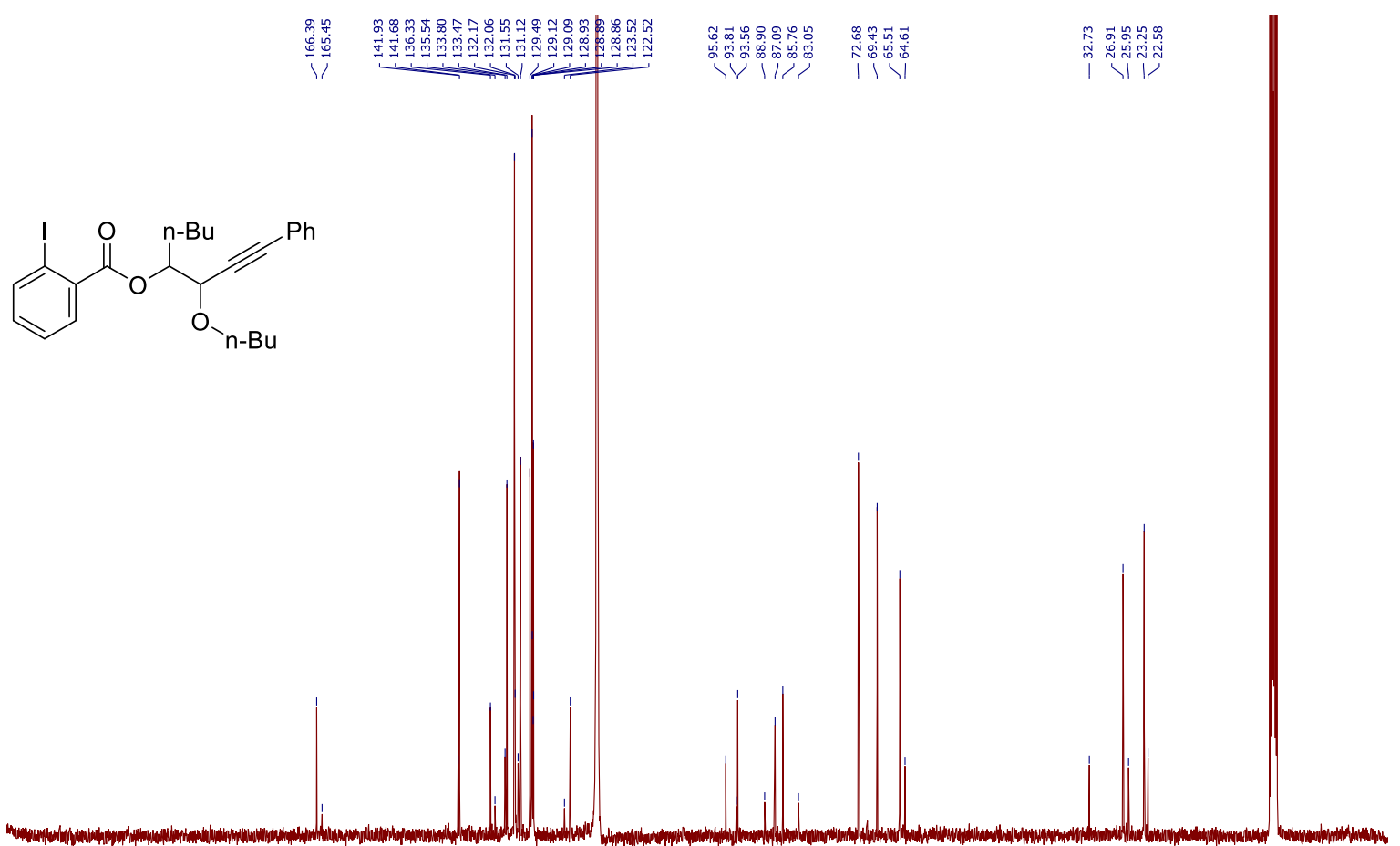

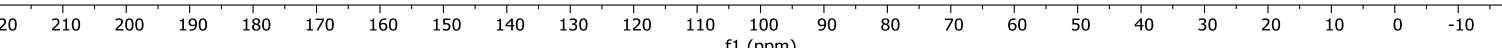


2-(phenylethynyl)tetrahydro-2H-pyran-3-yl 2-iodobenzoate (10ha) 3(phenylethynyl)tetrahydro-2H-pyran-2-yl 2-iodobenzoate (10hb); 4:1 regioisomeric mixture

${ }^{1} \mathrm{H}$ NMR (400 MHz, Acetonitrile- $d_{3}$ )

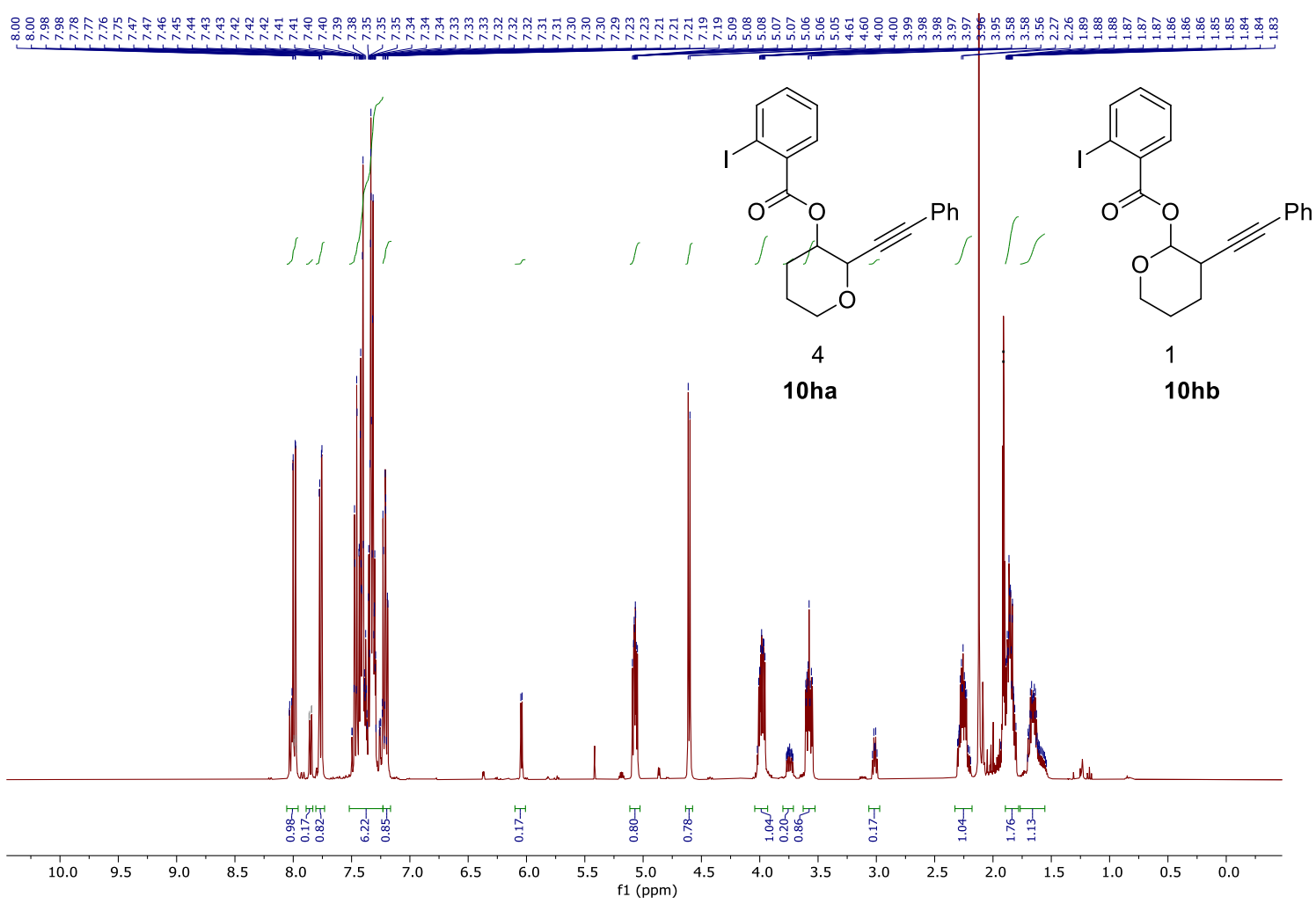

${ }^{13} \mathrm{C}$ NMR (400 MHz, Acetonitrile- $\left.d_{3}\right)$

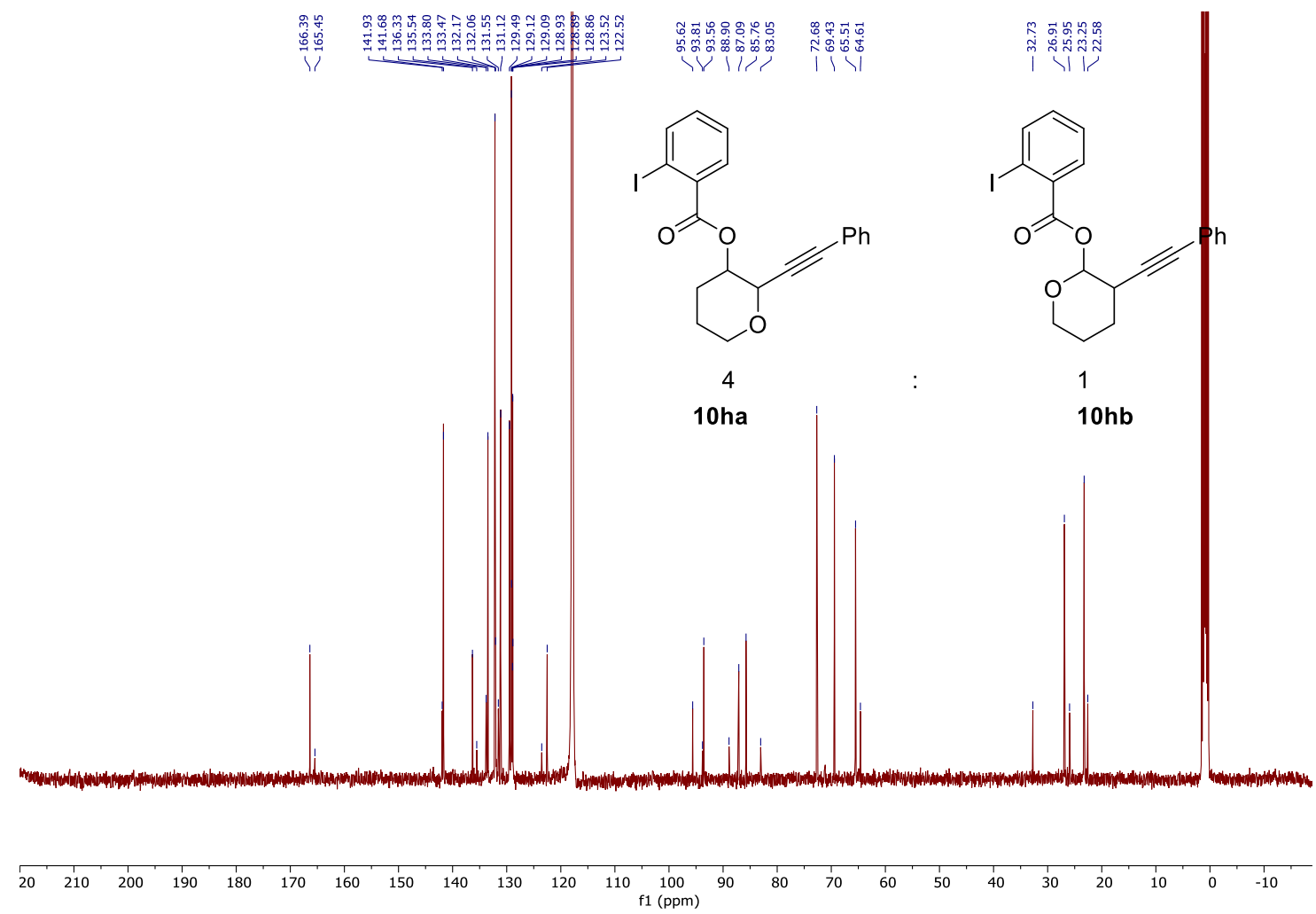


2-(((benzyloxy)carbonyl)(phenethyl)amino)-4-(4-(trifluoromethyl)phenyl)but-3-yn-1yl 2-iodobenzoate (12a)

${ }^{1} \mathrm{H}$ NMR (400 MHz, Acetonitrile- $d_{3}$ )

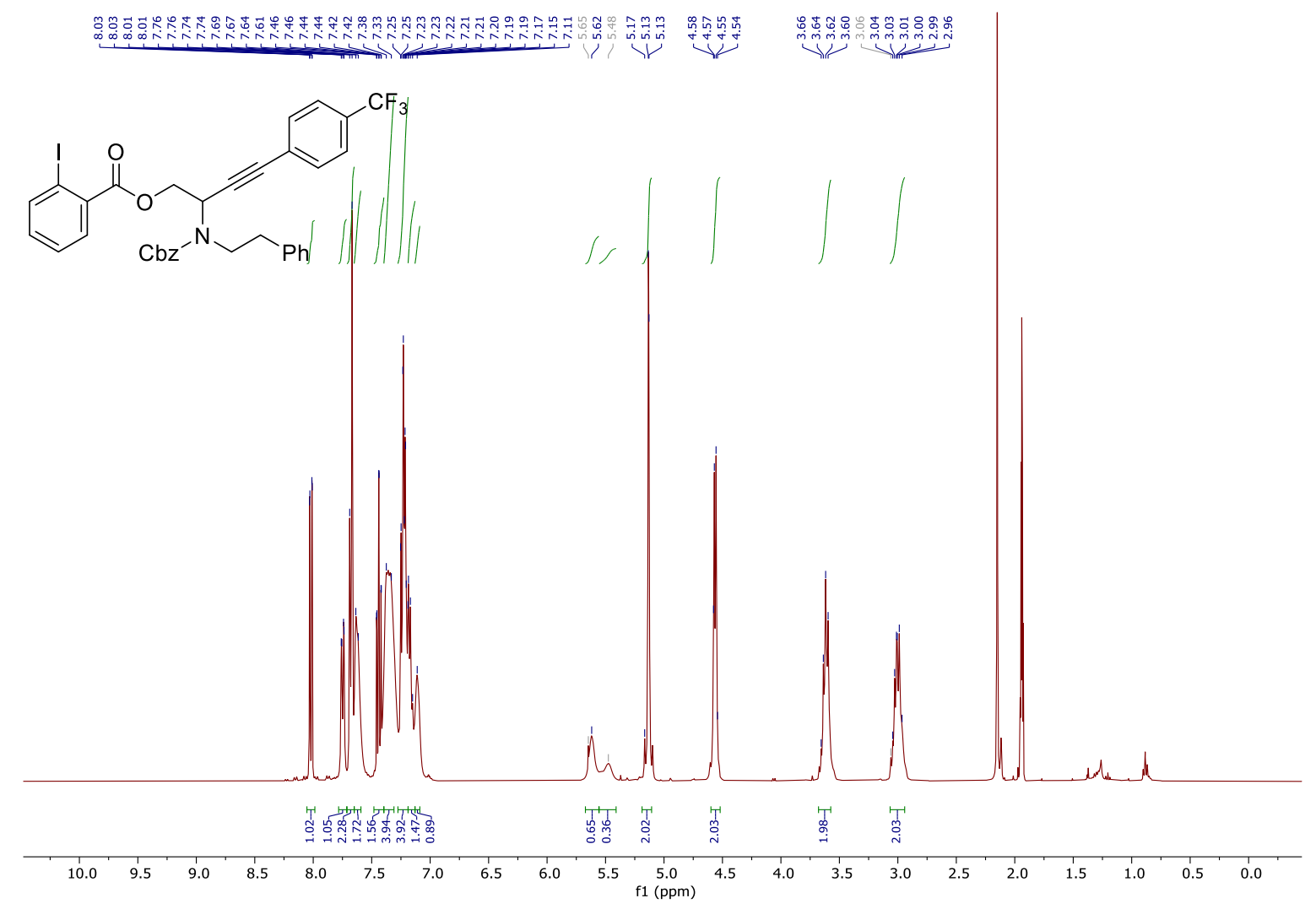

${ }^{13} \mathrm{C}$ NMR $\left(400 \mathrm{MHz}\right.$, Acetonitrile- $\left.d_{3}\right)$

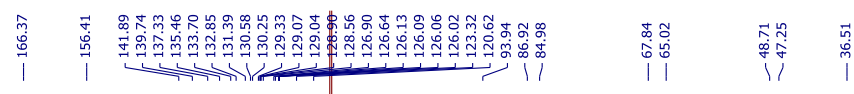<smiles>O=C(OCC(C#Cc1ccc(C(F)(F)F)cc1)N(CCc1ccccc1)Cc1ccccc1)c1ccccc1I</smiles>

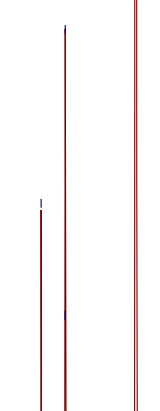

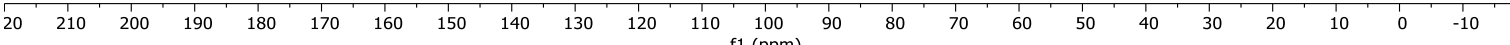


${ }^{19} \mathrm{~F}$ NMR (376 MHz, Acetonitrile- $d_{3}$ )

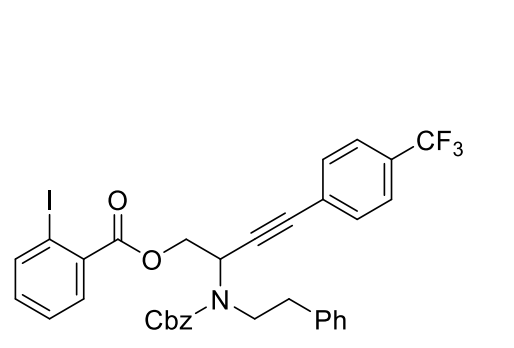

帛

\begin{tabular}{rllllllllllllllllllllll}
\hline 10 & 0 & -10 & -20 & -30 & -40 & -50 & -60 & -70 & -80 & -90 & -100 & -110 & -120 & -130 & -140 & -150 & -160 & -170 & -180 & -190 & -200 & -210
\end{tabular}

2-(((benzyloxy)carbonyl)(phenethyl)amino)-4-(4-bromophenyl)but-3-yn-1-yl iodobenzoate (12b)

${ }^{1} \mathrm{H}$ NMR (400 MHz, Acetonitrile- $d_{3}$ ) 


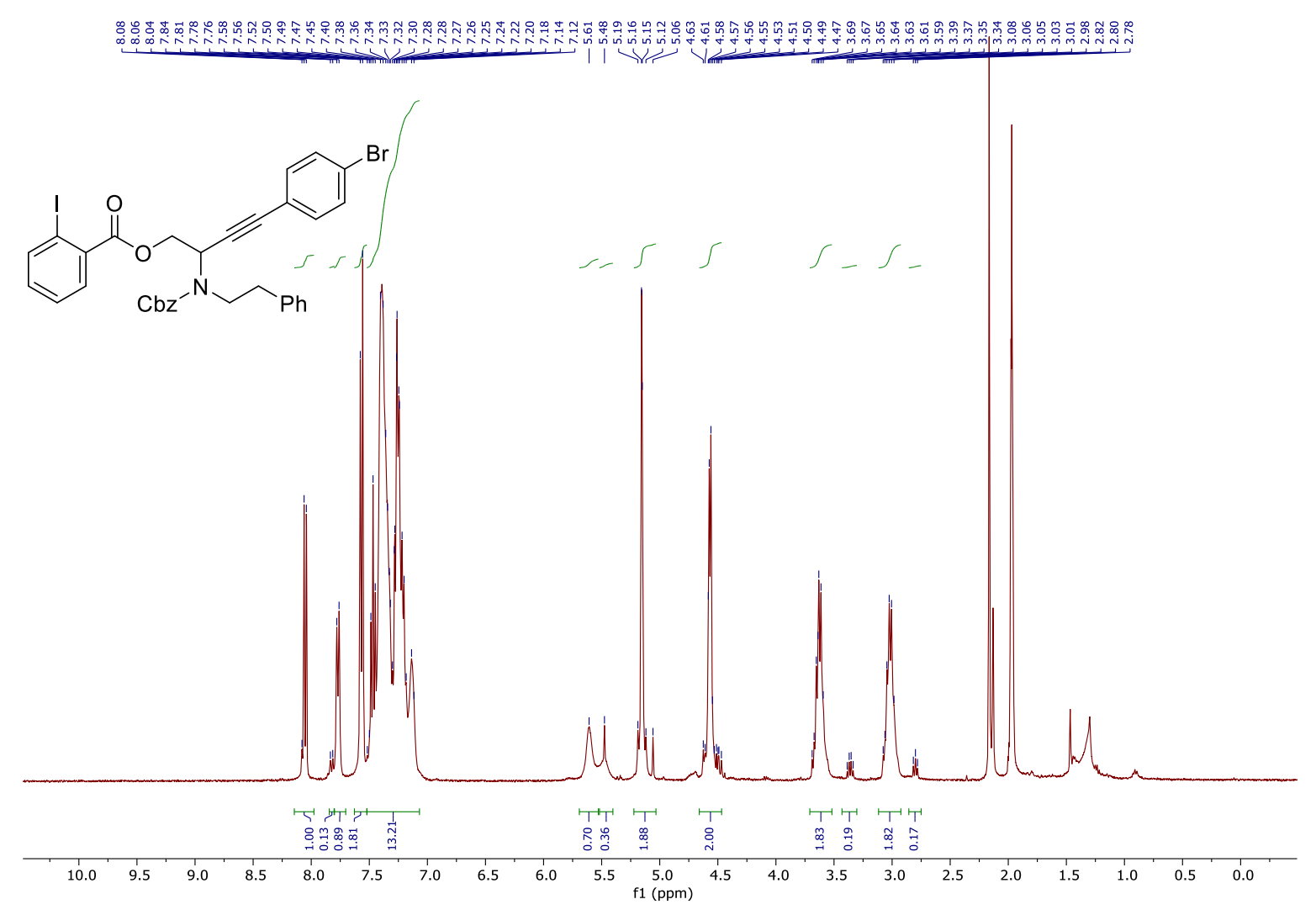

${ }^{13} \mathrm{C} \mathrm{NMR}\left(400 \mathrm{MHz}\right.$, Acetonitrile- $\left.d_{3}\right)$

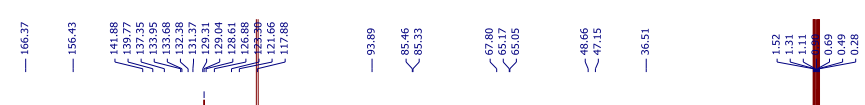

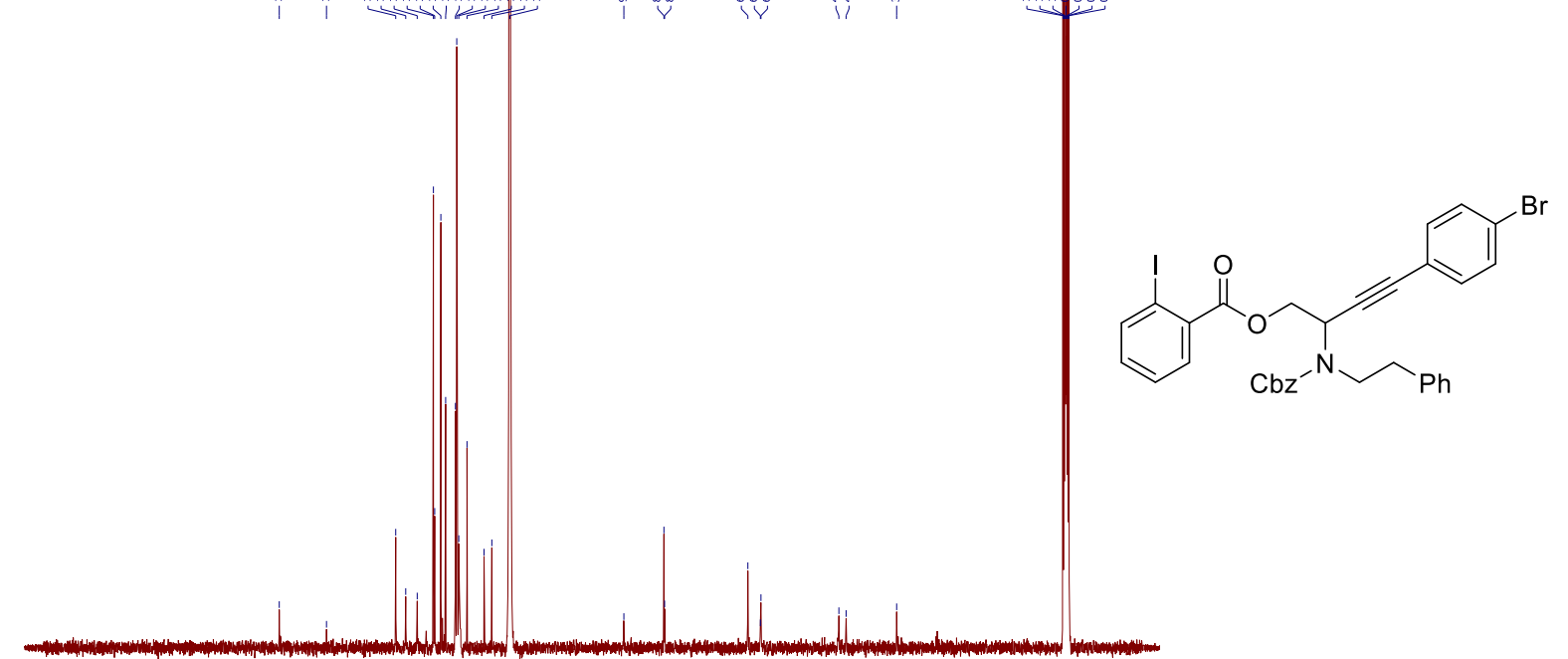

\begin{tabular}{lllllllllllllllllllllllllll}
20 & 210 & 200 & 190 & 180 & 170 & 160 & 150 & 140 & 130 & 120 & 110 & $\begin{array}{l}100 \\
\mathrm{f}(\mathrm{pom})\end{array}$ & 90 & 80 & 70 & 60 & 50 & 40 & 30 & 20 & 10 & 0 & -10 \\
\hline
\end{tabular} 
COSY NMR (400 MHz, Acetonitrile- $\left.d_{3}\right)$ Correlation between 1 and 2 and $1^{\prime}$ and $2^{\prime}$

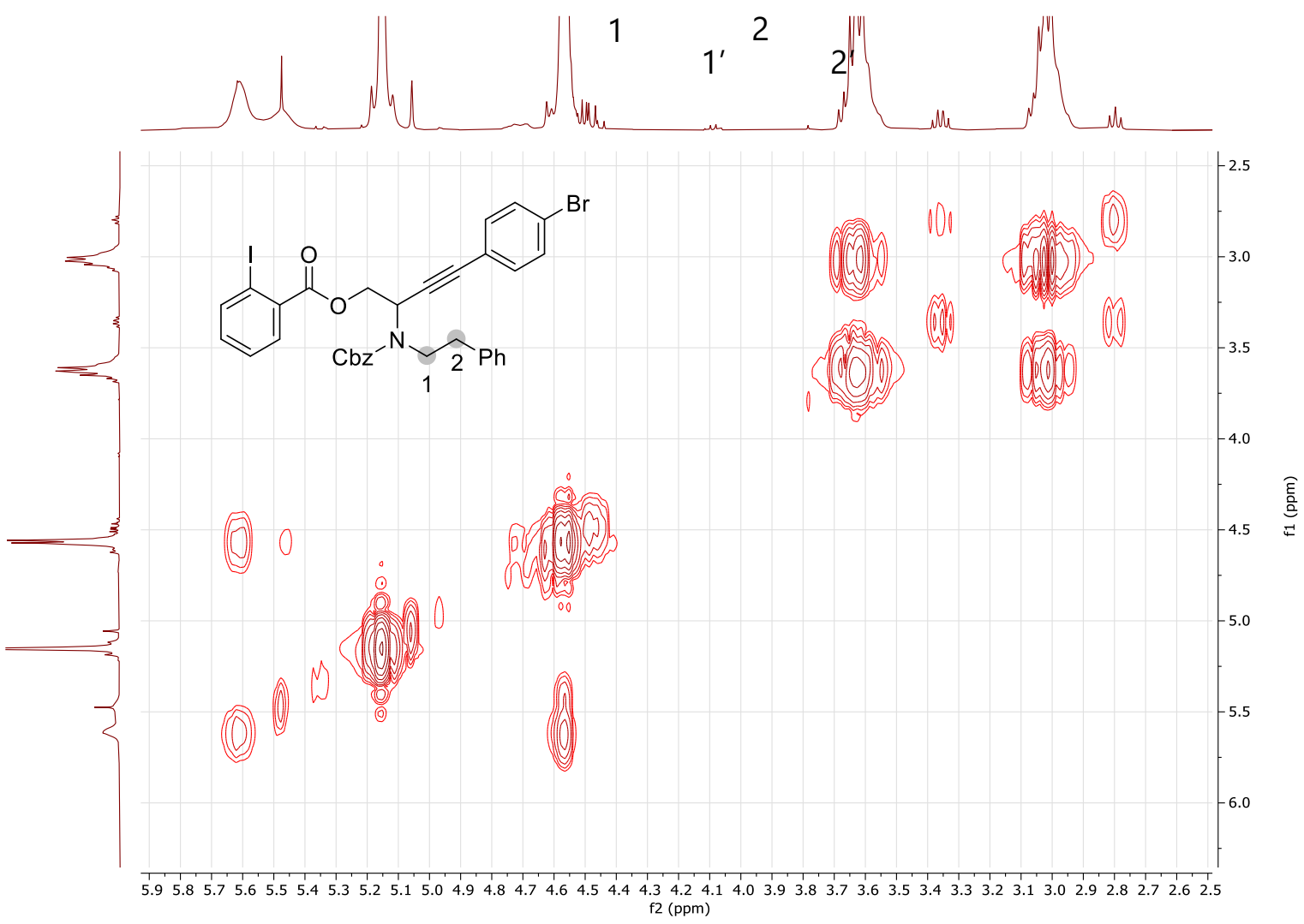

HMBC NMR (400 MHz, Acetonitrile- $d_{3}$ ) Correlation between 2 and $2^{\prime}$ to the same carbons

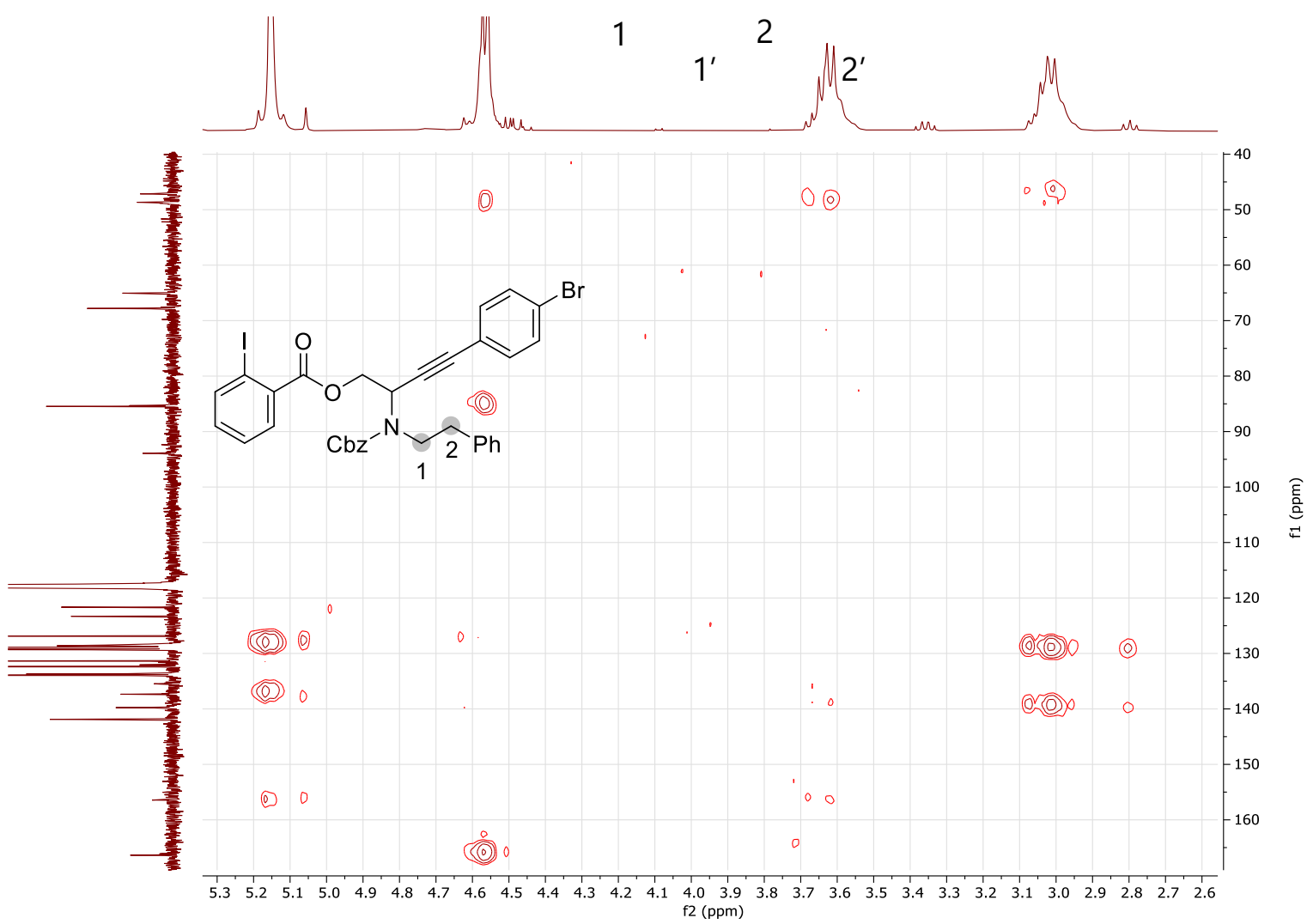


4-(2-bromophenyl)-2-(2-oxooxazolidin-3-yl)but-3-yn-1-yl 2-iodobenzoate (12c) ${ }^{1} \mathrm{H}$ NMR $\left(400 \mathrm{MHz}\right.$, Acetonitrile- $\left.d_{3}\right)$

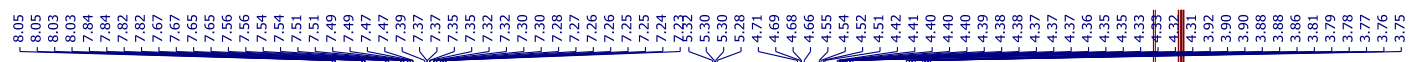

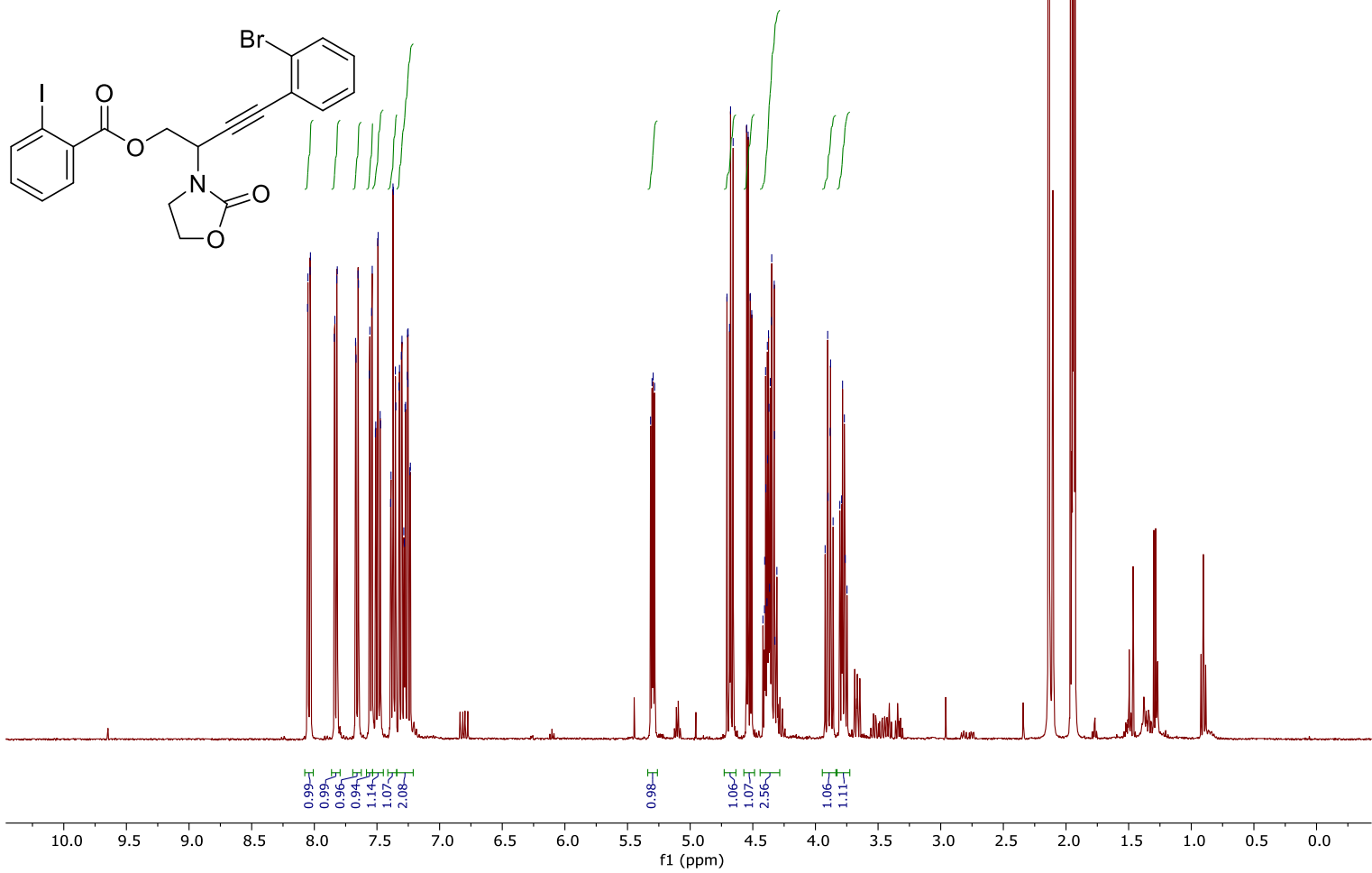

${ }^{13} \mathrm{C}$ NMR (400 MHz, Acetonitrile- $\left.d_{3}\right)$

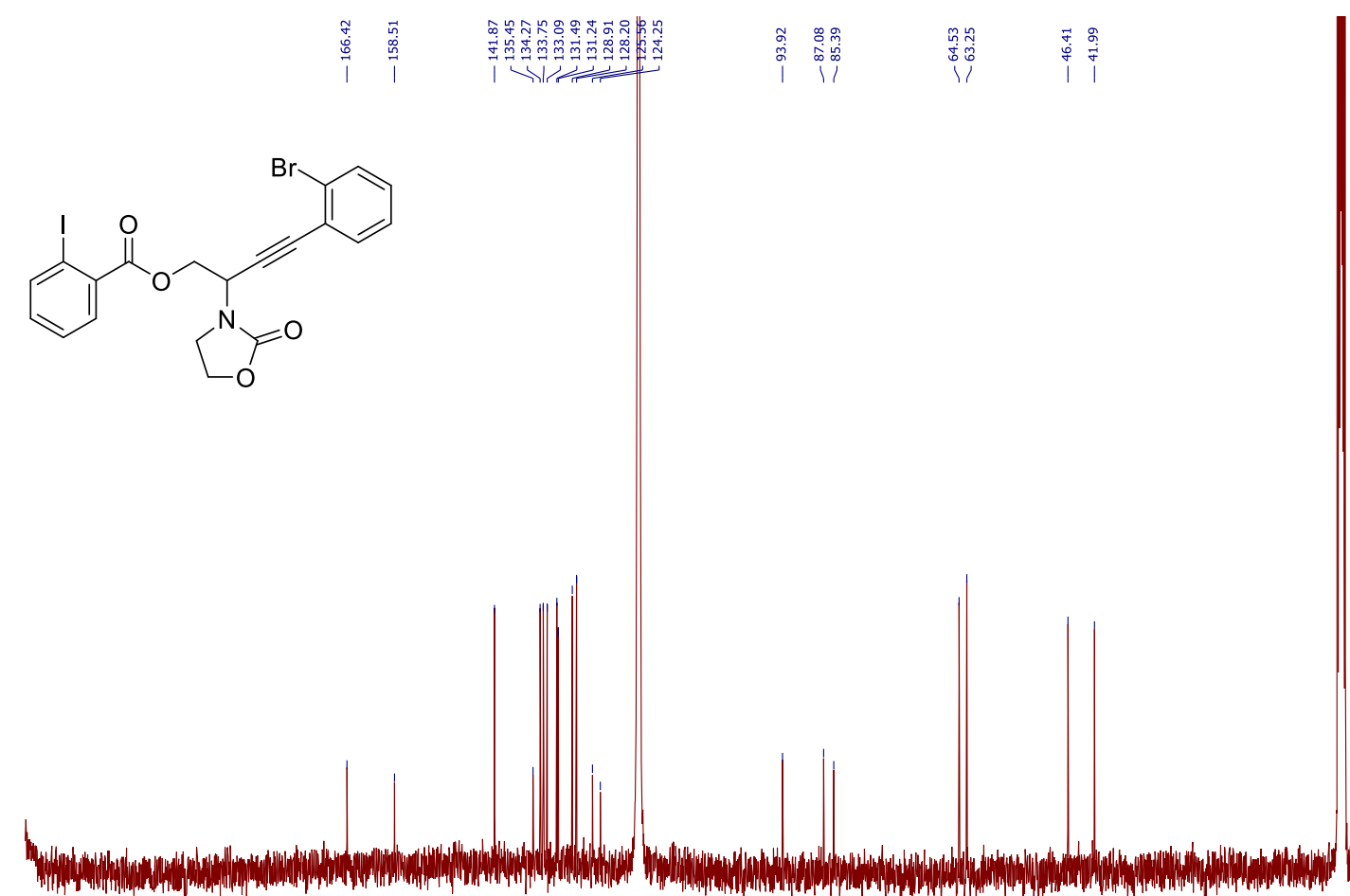

$\begin{array}{llllllllllllllllllllllll}20 & 210 & 200 & 190 & 180 & 170 & 160 & 150 & 140 & 130 & 120 & 110 & 100 & 90 & 80 & 70 & 60 & 50 & 40 & 30 & 20 & 10 & 0 & -10\end{array}$ 
2-(((benzyloxy)carbonyl)(phenethyl)amino)-4-(3-fluorophenyl)but-3-yn-1-yl iodobenzoate (12d)

${ }^{1} \mathrm{H}$ NMR (400 MHz, chloroform-d)

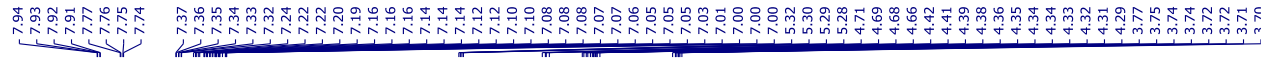
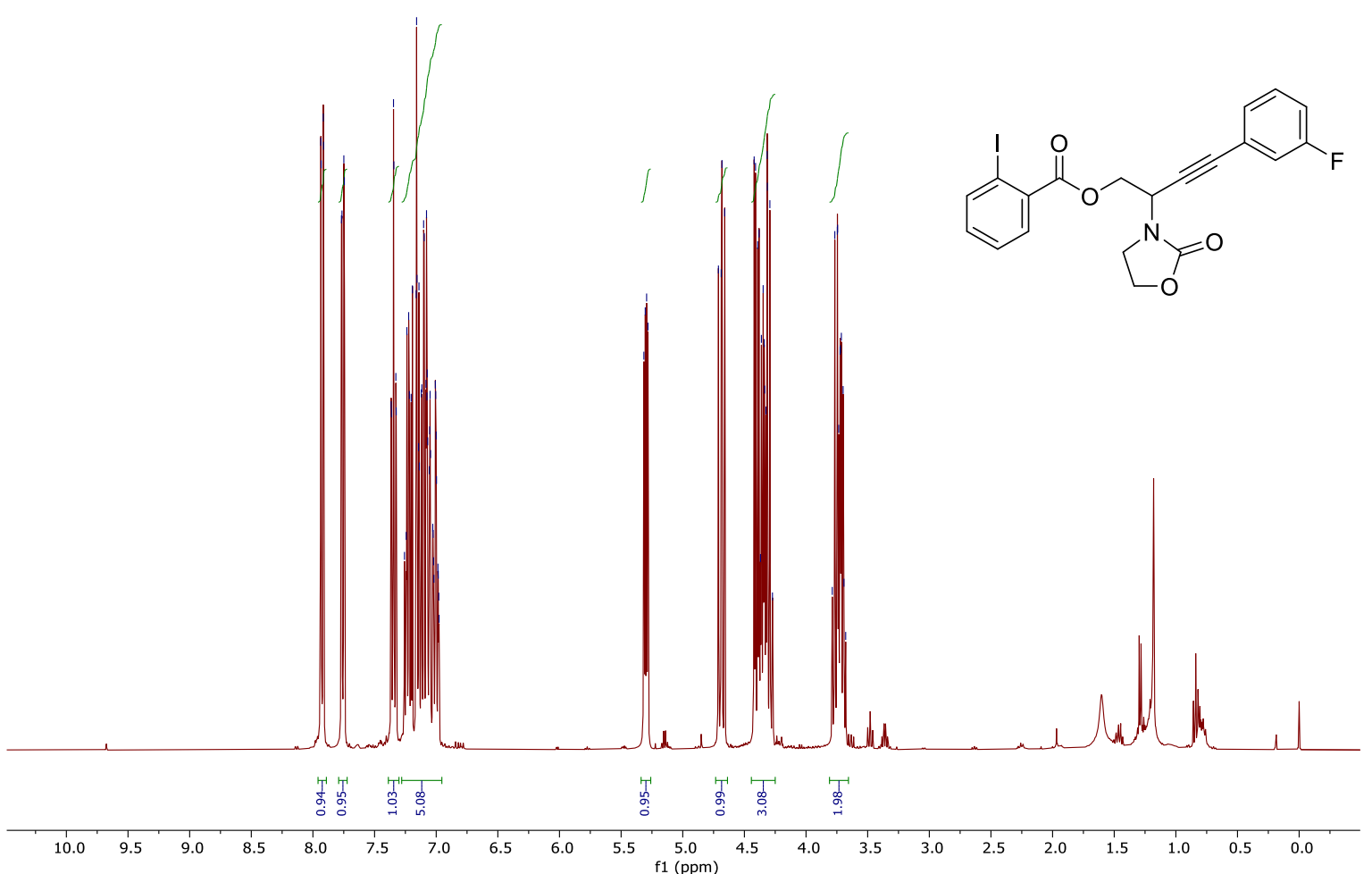

${ }^{13} \mathrm{C}$ NMR $(400 \mathrm{MHz}$, chloroform-d)

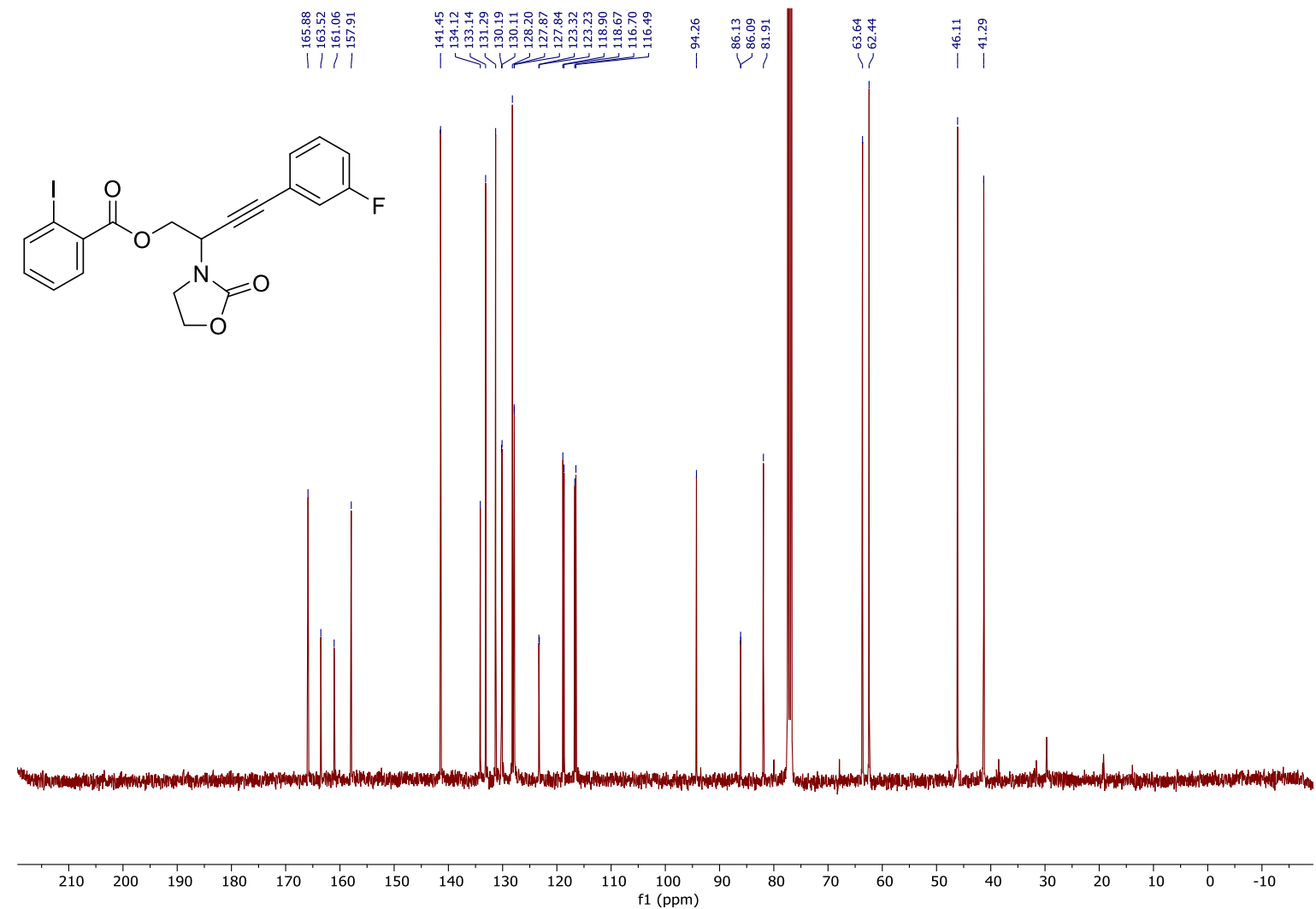


${ }^{19} \mathrm{~F}$ NMR $\left(376 \mathrm{MHz}\right.$, Chloroform- $\left.d_{3}\right)$

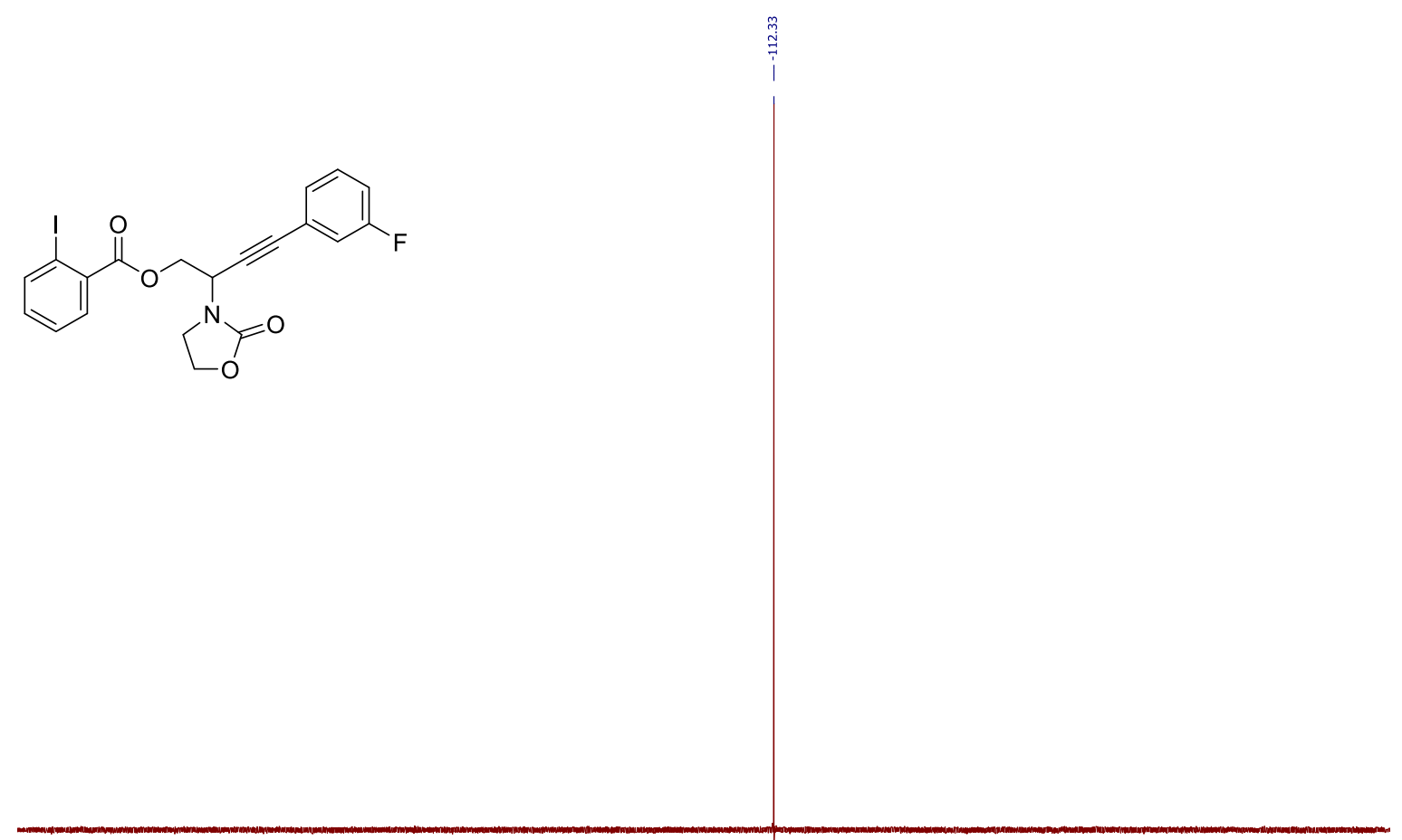

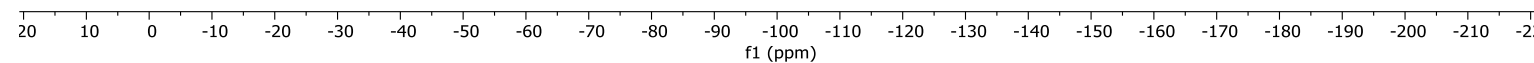


(4-methylphenyl)but-3-yn-1-yl 2-iodobenzoate (12e)

${ }^{1} \mathrm{H}$ NMR (400 MHz, Acetonitrile- $d_{3}$ )

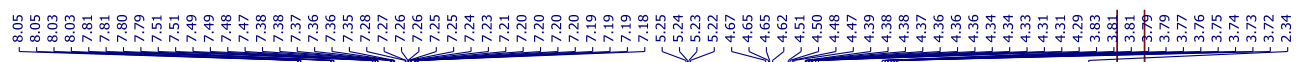
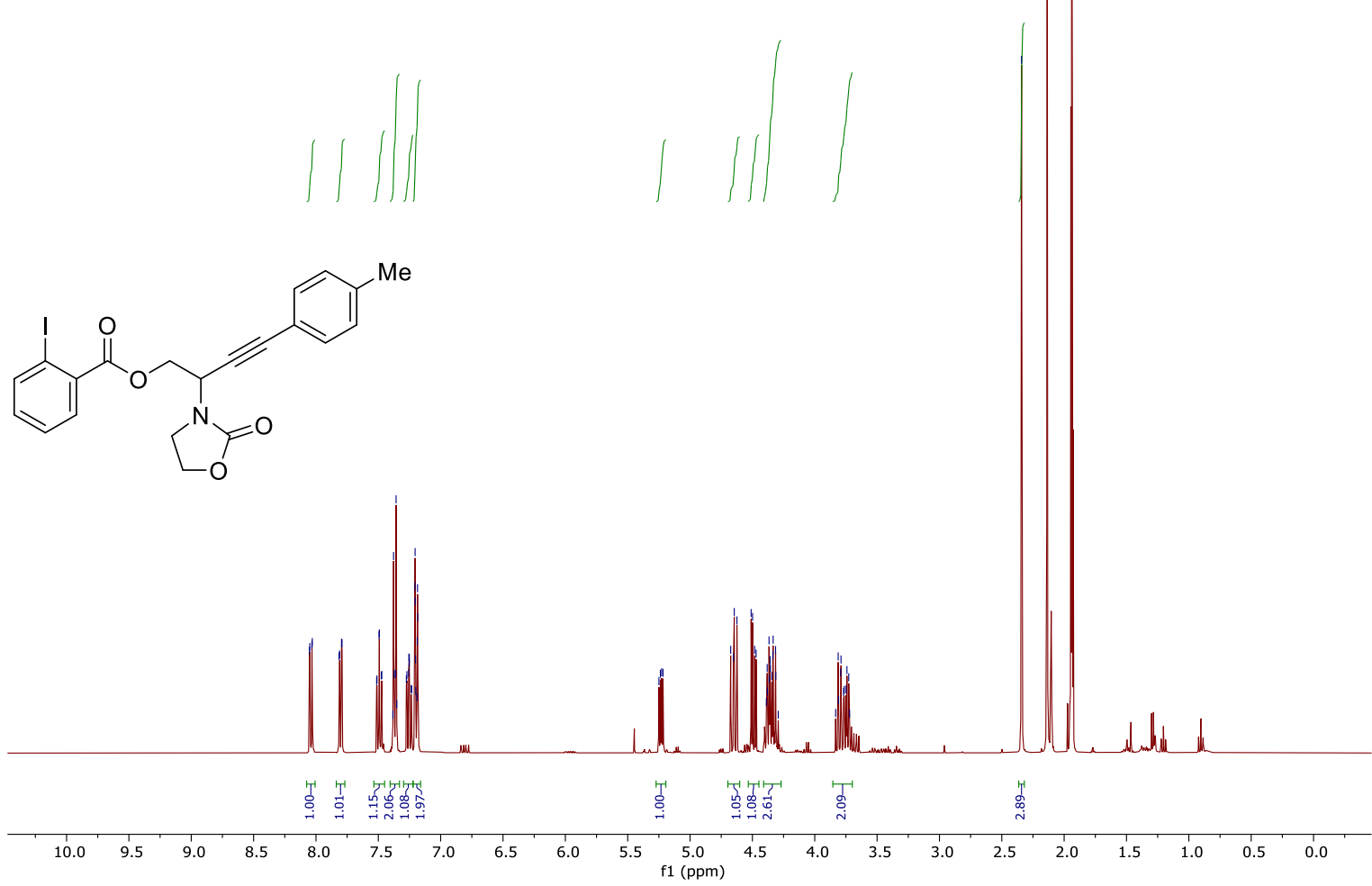

${ }^{13} \mathrm{C}$ NMR (400 MHz, Acetonitrile- $\left.d_{3}\right)$

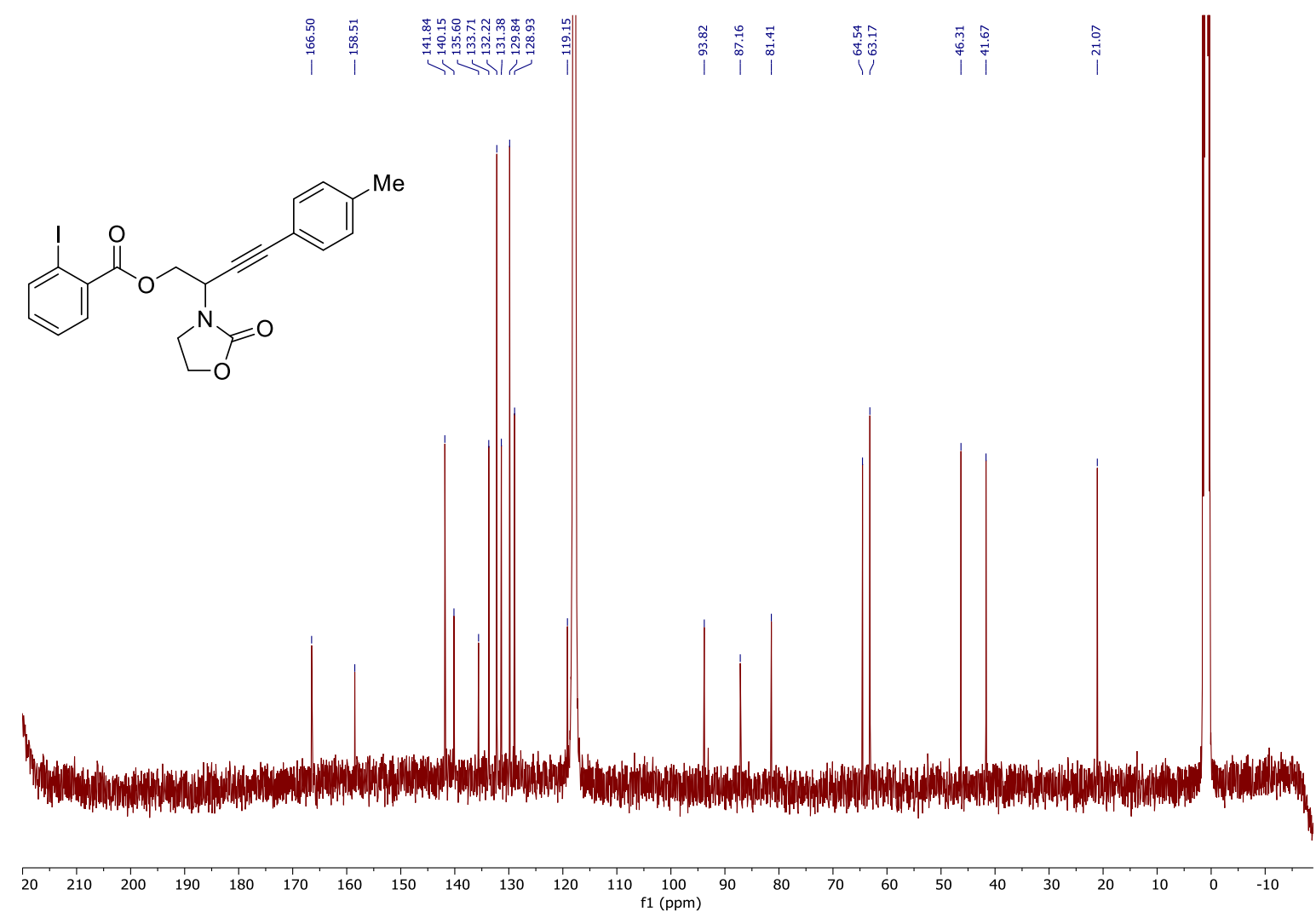


2-(((benzyloxy)carbonyl)(phenethyl)amino)-4-(triisopropylsilyl)but-3-yn-1-yl iodobenzoate (12f)

${ }^{1} \mathrm{H}$ NMR (400 MHz, Acetonitrile- $d_{3}$ )

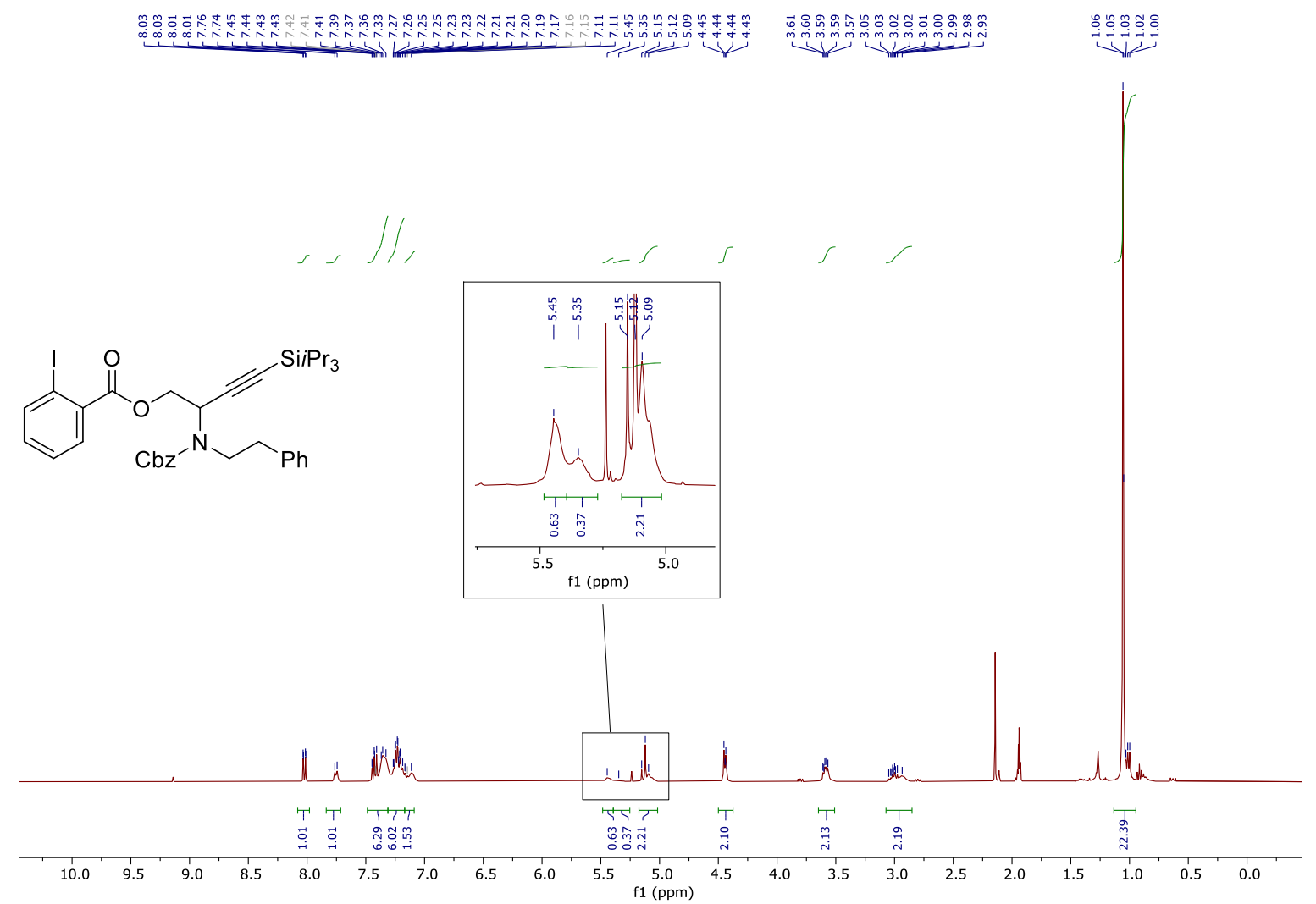

${ }^{13} \mathrm{C}$ NMR $\left(101 \mathrm{MHz}\right.$, Acetonitrile- $\left.d_{3}\right)$

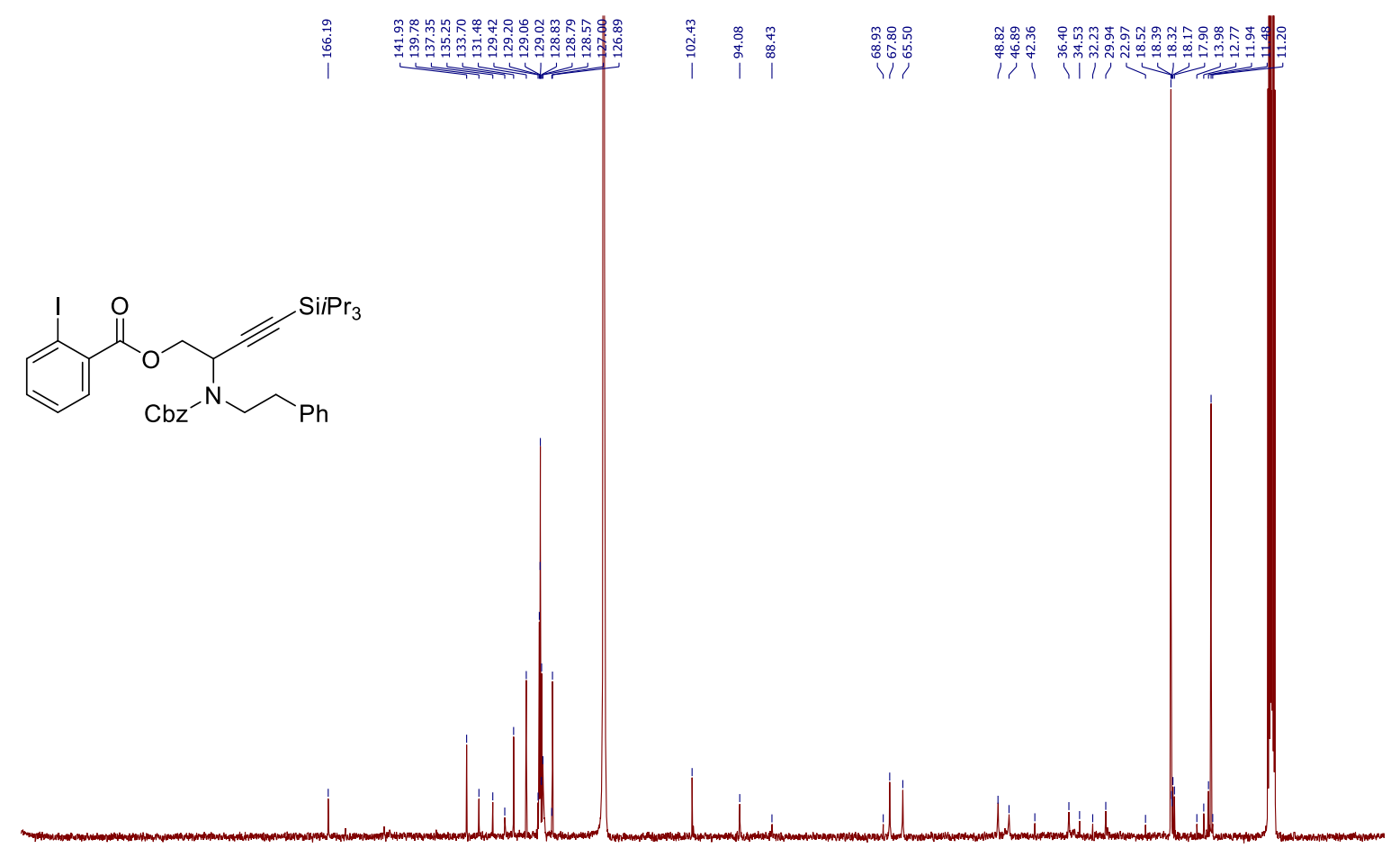

\begin{tabular}{llllllllllllllllllllllll}
\hline 20 & 210 & 200 & 190 & 180 & 170 & 160 & 150 & 140 & 130 & 120 & 110 & 100 & 90 & 80 & 70 & 60 & 50 & 40 & 30 & 20 & 10 & 0 & -10
\end{tabular} 
4-(4-((3-bromopropoxy)carbonyl)phenyl)-2-(2-oxooxazolidin-3-yl)but-3-yn-1-yl $2-$ iodobenzoate (12g)

${ }^{1} \mathrm{H}$ NMR (400 MHz, chloroform-d)

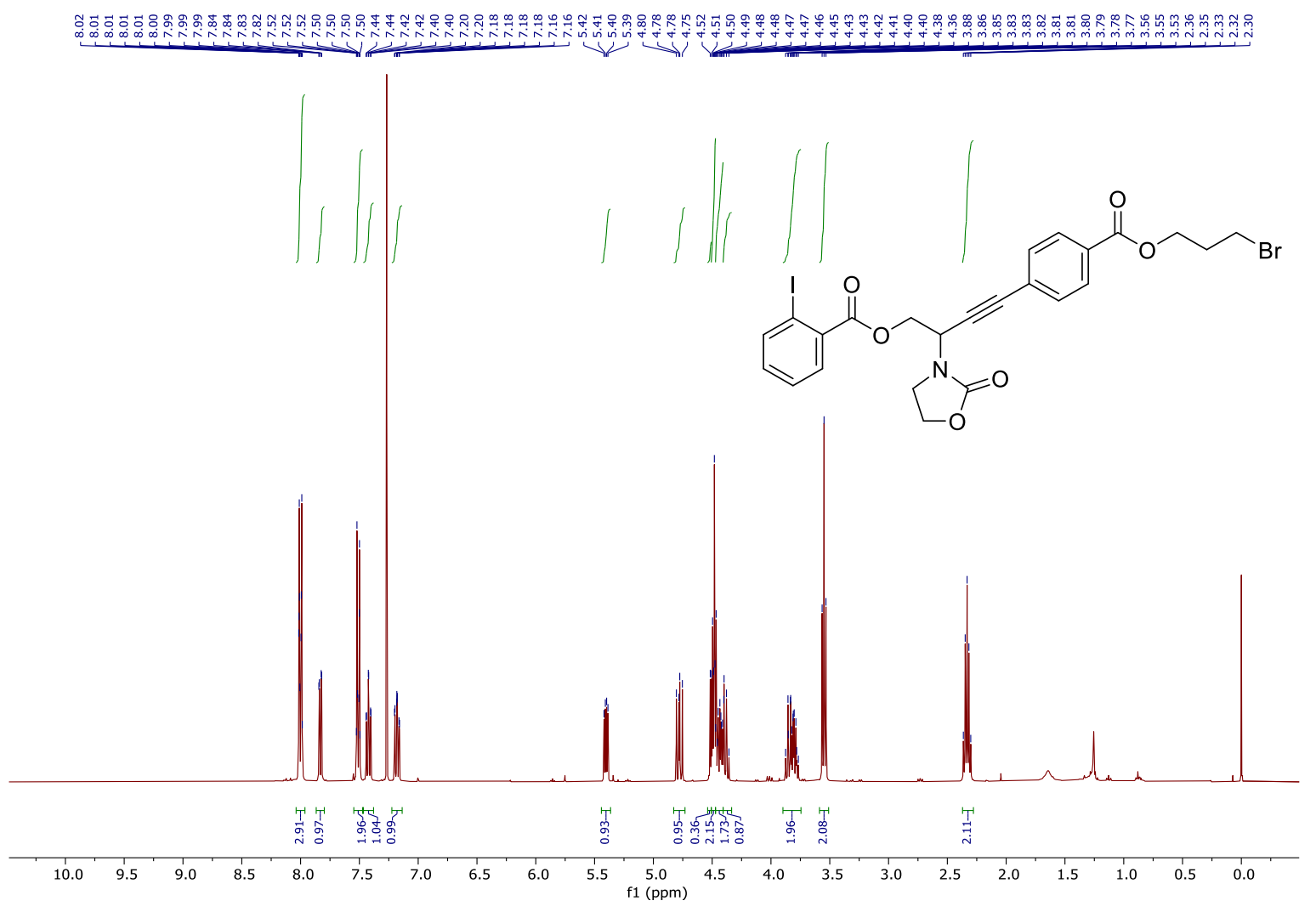

${ }^{13} \mathrm{C}$ NMR $(400 \mathrm{MHz}$, chloroform-d)

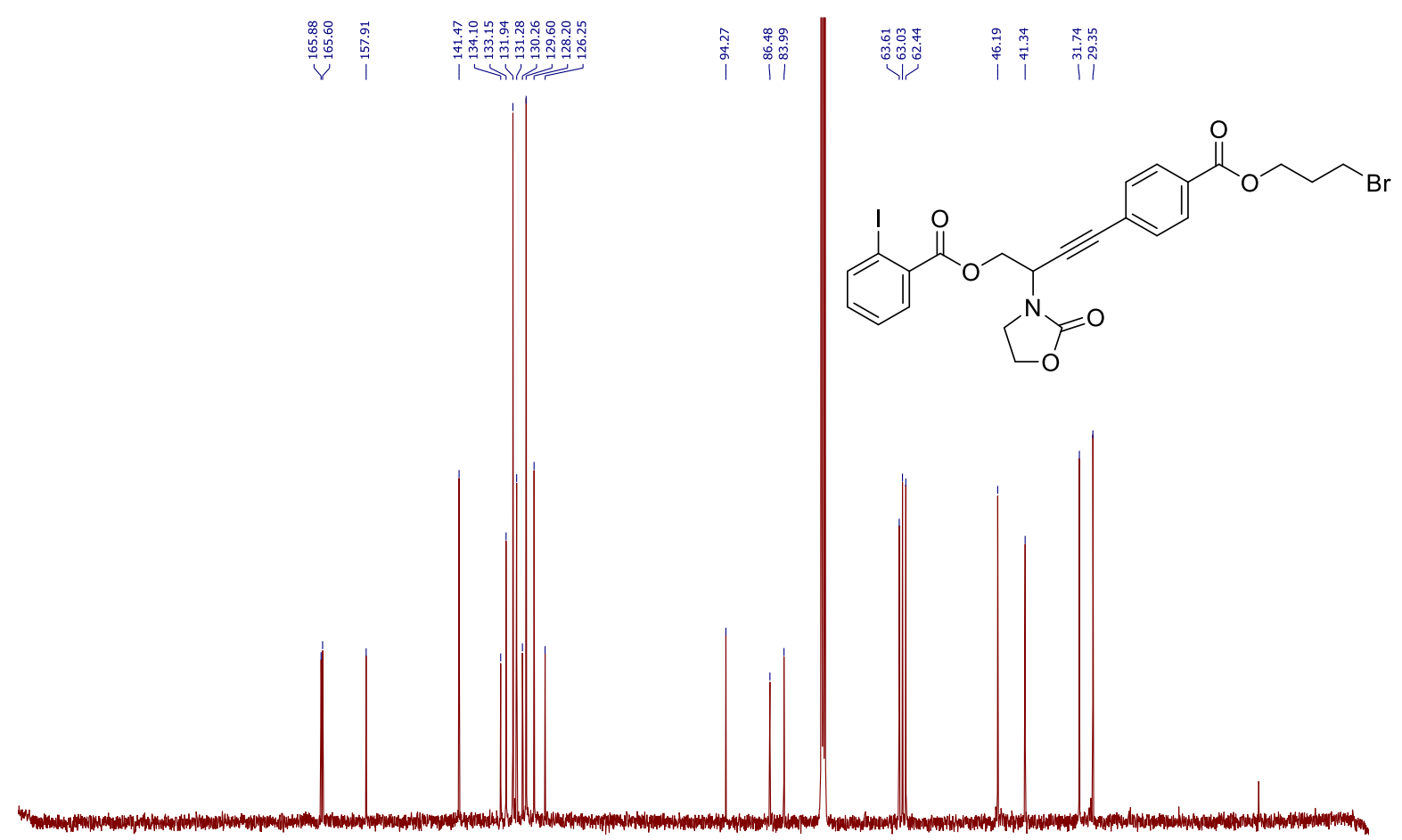

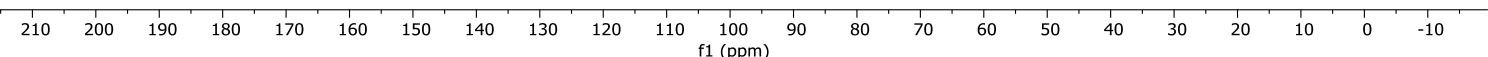



iodobenzoate (12h)

${ }^{1} \mathrm{H}$ NMR (400 MHz, chloroform-d)
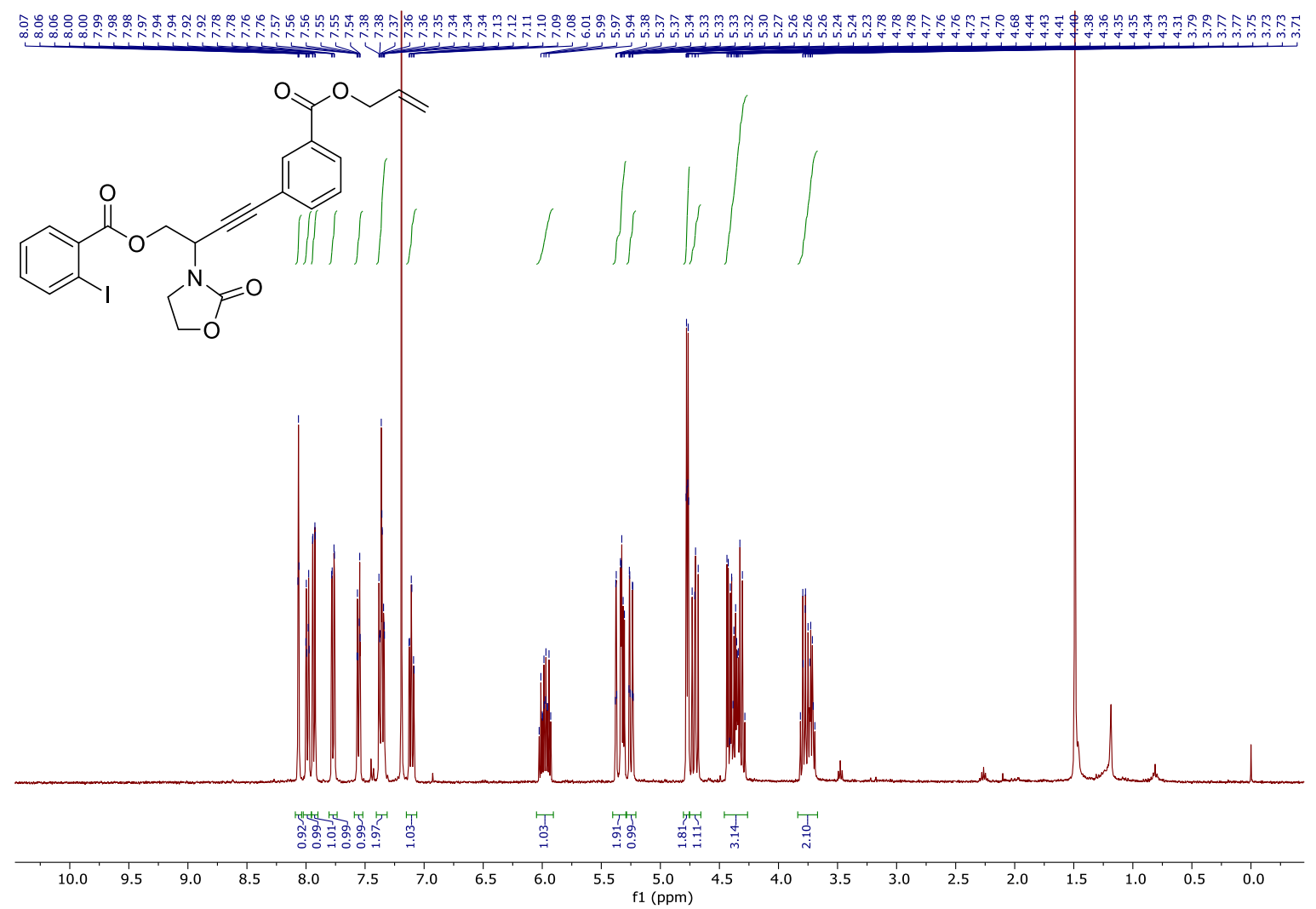

${ }^{13} \mathrm{C}$ NMR (400 MHz, chloroform-d)

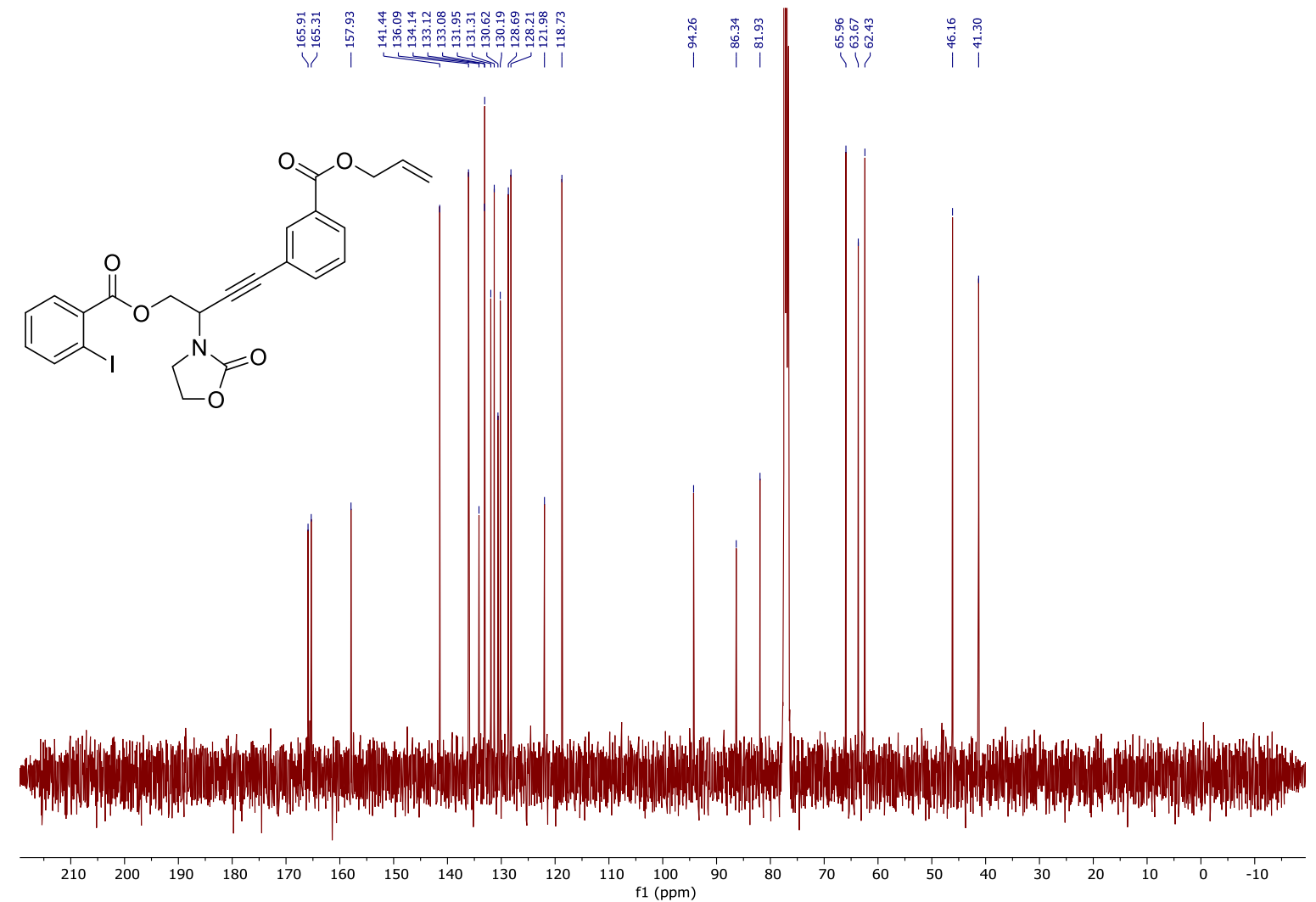


2-butoxy-4-(4-(trifluoromethyl)phenyl)but-3-yn-1-yl 2-iodobenzoate (12i) ${ }^{1} \mathrm{H}$ NMR (400 MHz, chloroform-d)

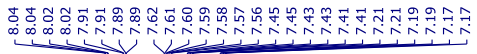
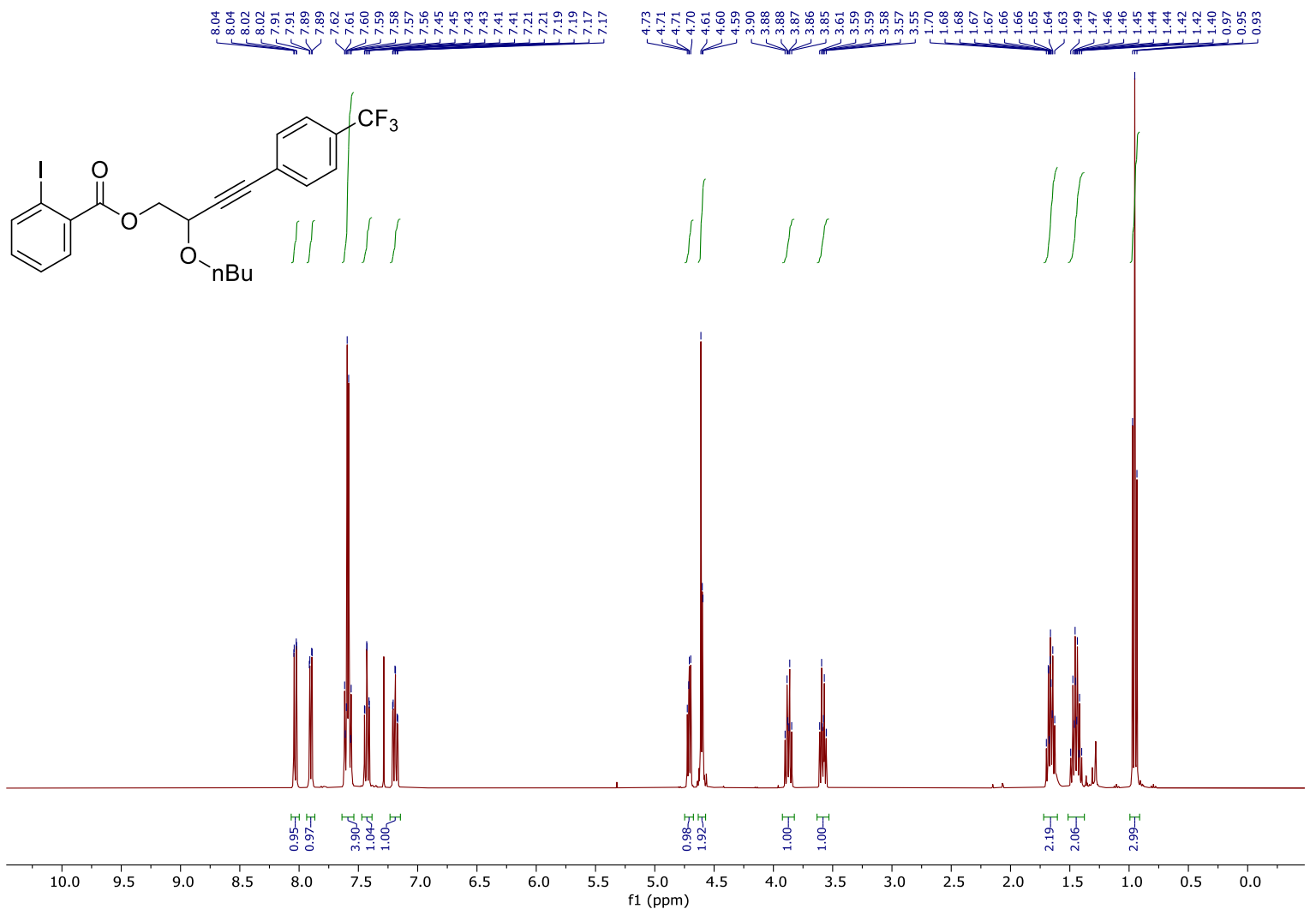

${ }^{13} \mathrm{C}$ NMR (400 MHz, chloroform-d)

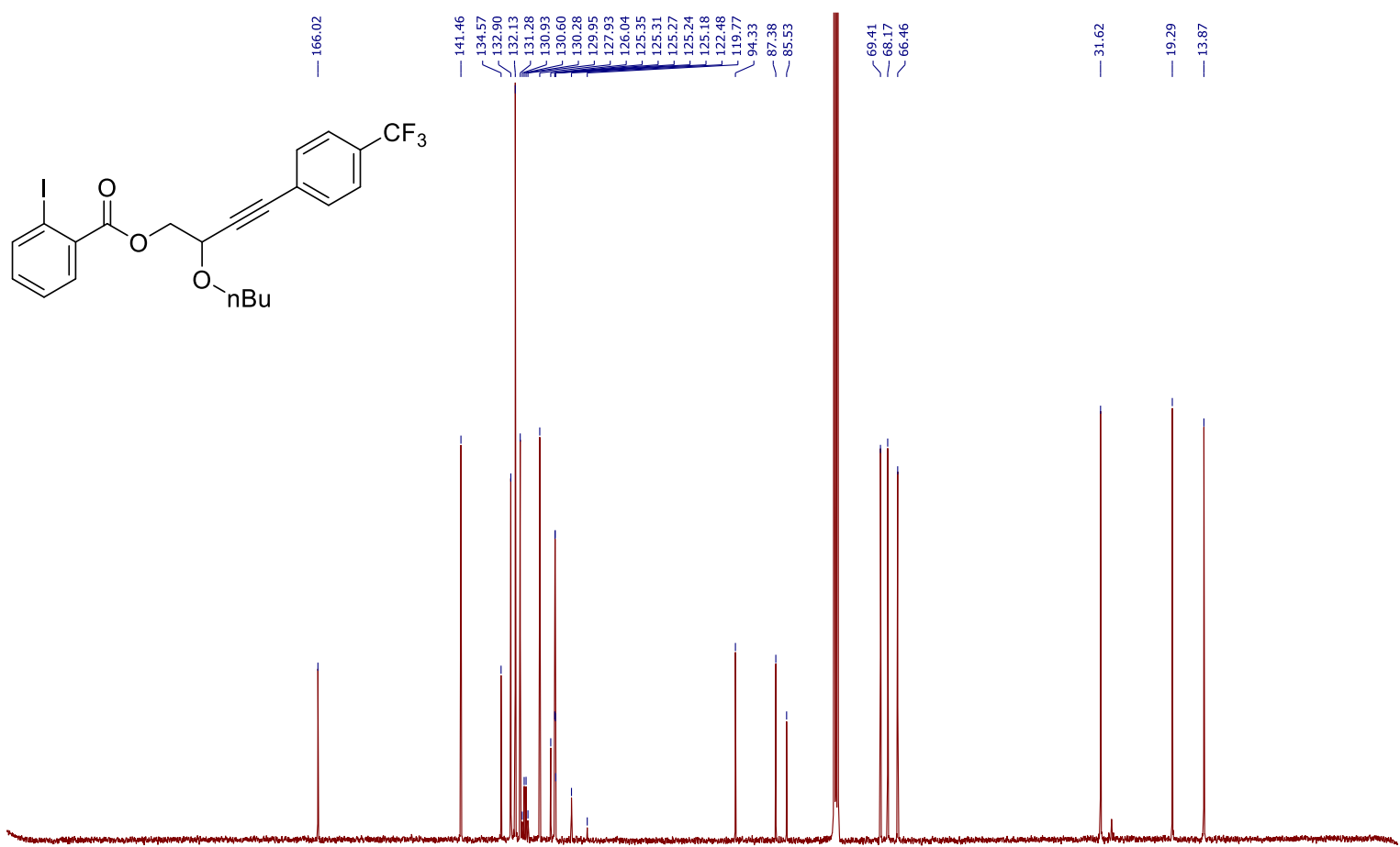

$\begin{array}{lllllllllllllllllllllllllll}1 & 10 & 200 & 190 & 180 & 170 & 160 & 150 & 140 & 130 & 120 & 110 & 100 & 90 & 80 & 70 & 60 & 50 & 40 & 30 & 20 & 10 & 0 & -10\end{array}$ 
${ }^{19} \mathrm{~F}$ NMR (376 MHz, Chloroform-d)

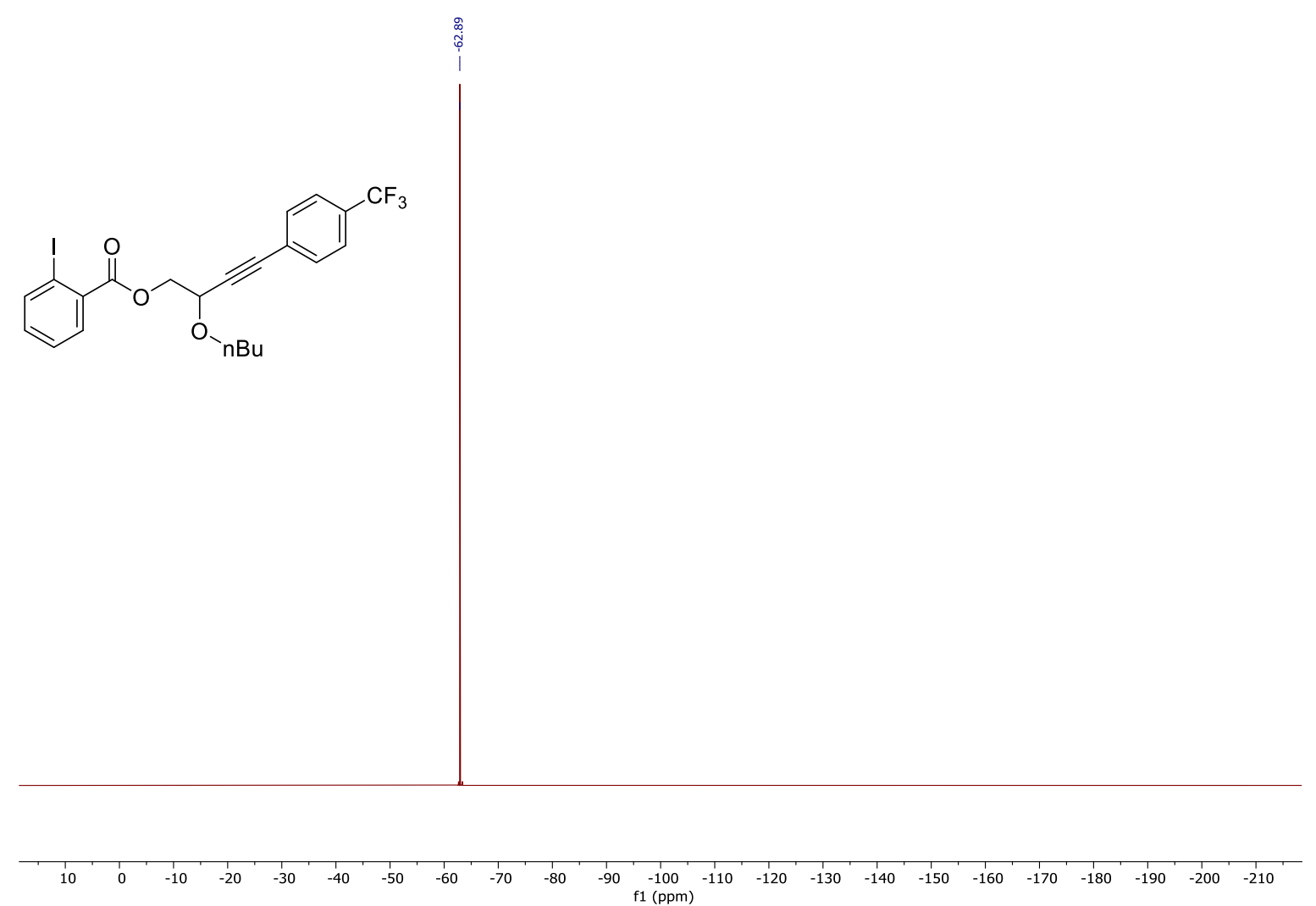


4-(4-((3-bromopropoxy)carbonyl)phenyl)-2-butoxybut-3-yn-1-yl

2-iodobenzoate

(12j)

${ }^{1} \mathrm{H}$ NMR (400 MHz, chloroform-d)

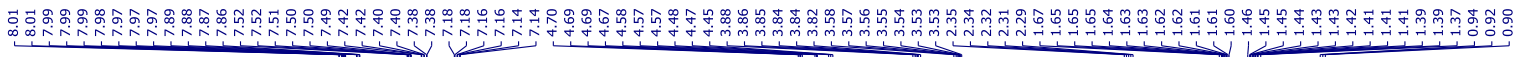<smiles>C=CCCOC(=O)c1cc(C)c(C#CC(COC(=O)c2ccccc2I)O[14C](=O)c2ccccc2)cc1C</smiles>
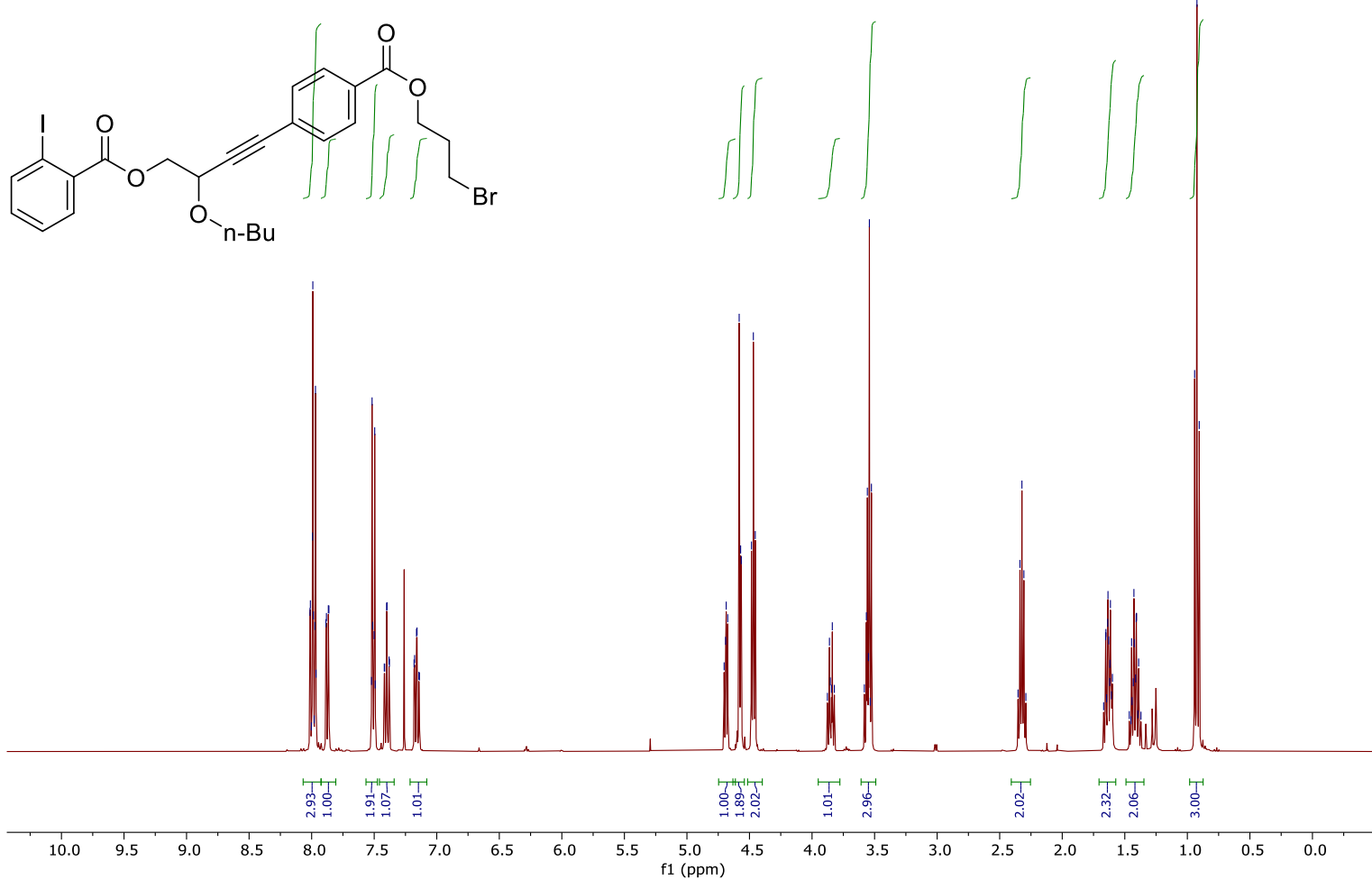

${ }^{13} \mathrm{C}$ NMR $(400 \mathrm{MHz}$, chloroform-d)

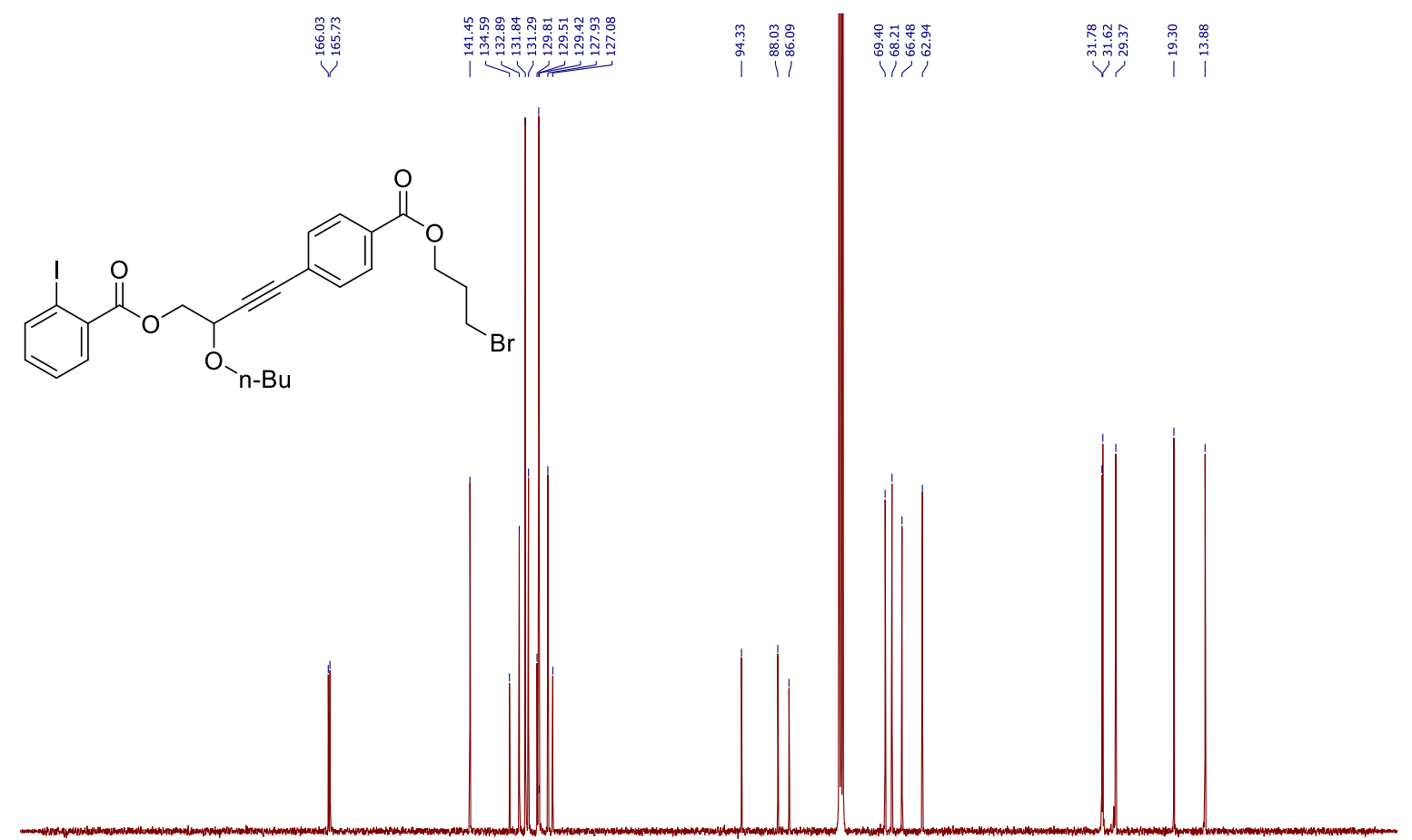

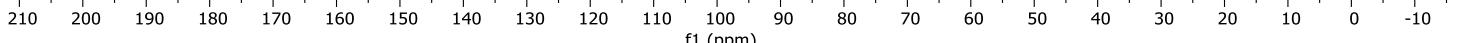


Product modification

1-(1-hydroxy-4-phenylbut-3-yn-2-yl)pyrrolidin-2-one (13)

${ }^{1} \mathrm{H}$ NMR (400 MHz, Chloroform-d)

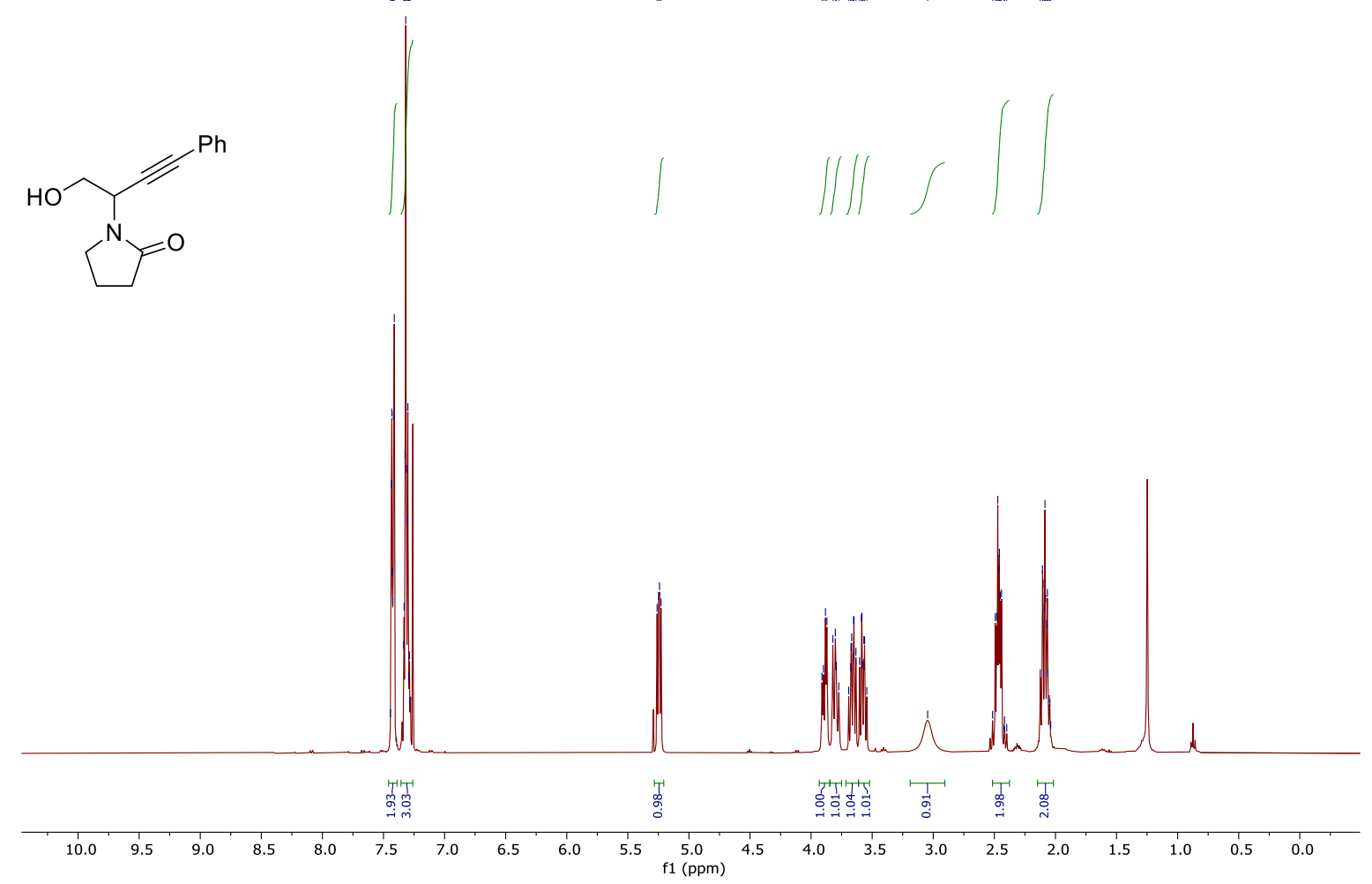

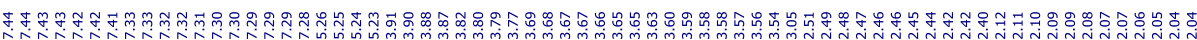

${ }^{13} \mathrm{C}$ NMR (101 MHz, Chloroform-d) 


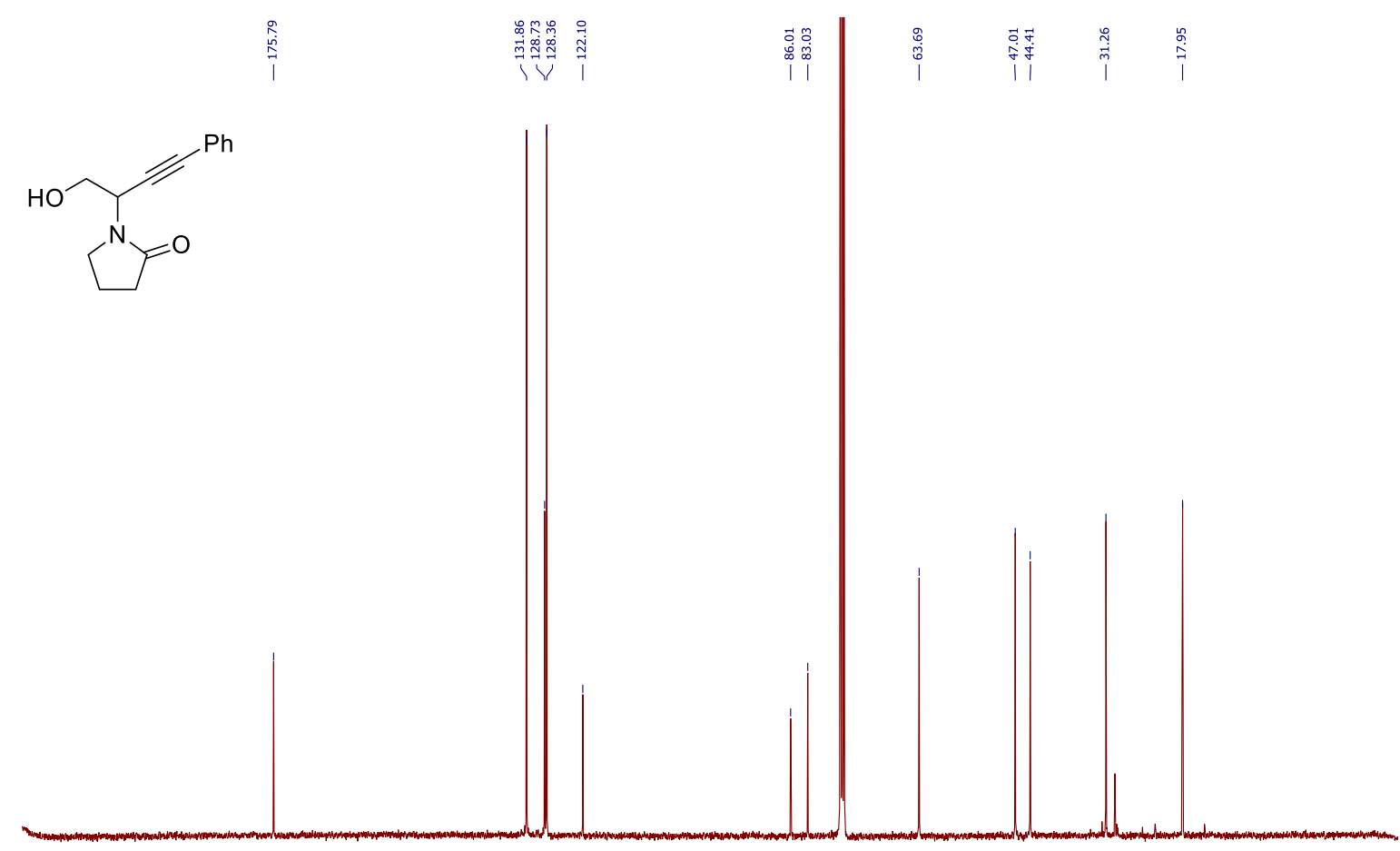

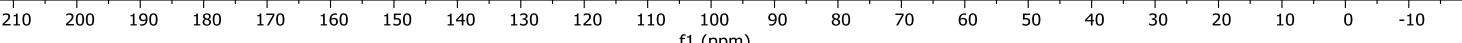

2-butoxy-4-phenylbut-3-yn-1-ol (14)

${ }^{1} \mathrm{H}$ NMR (400 MHz, chloroform-d)

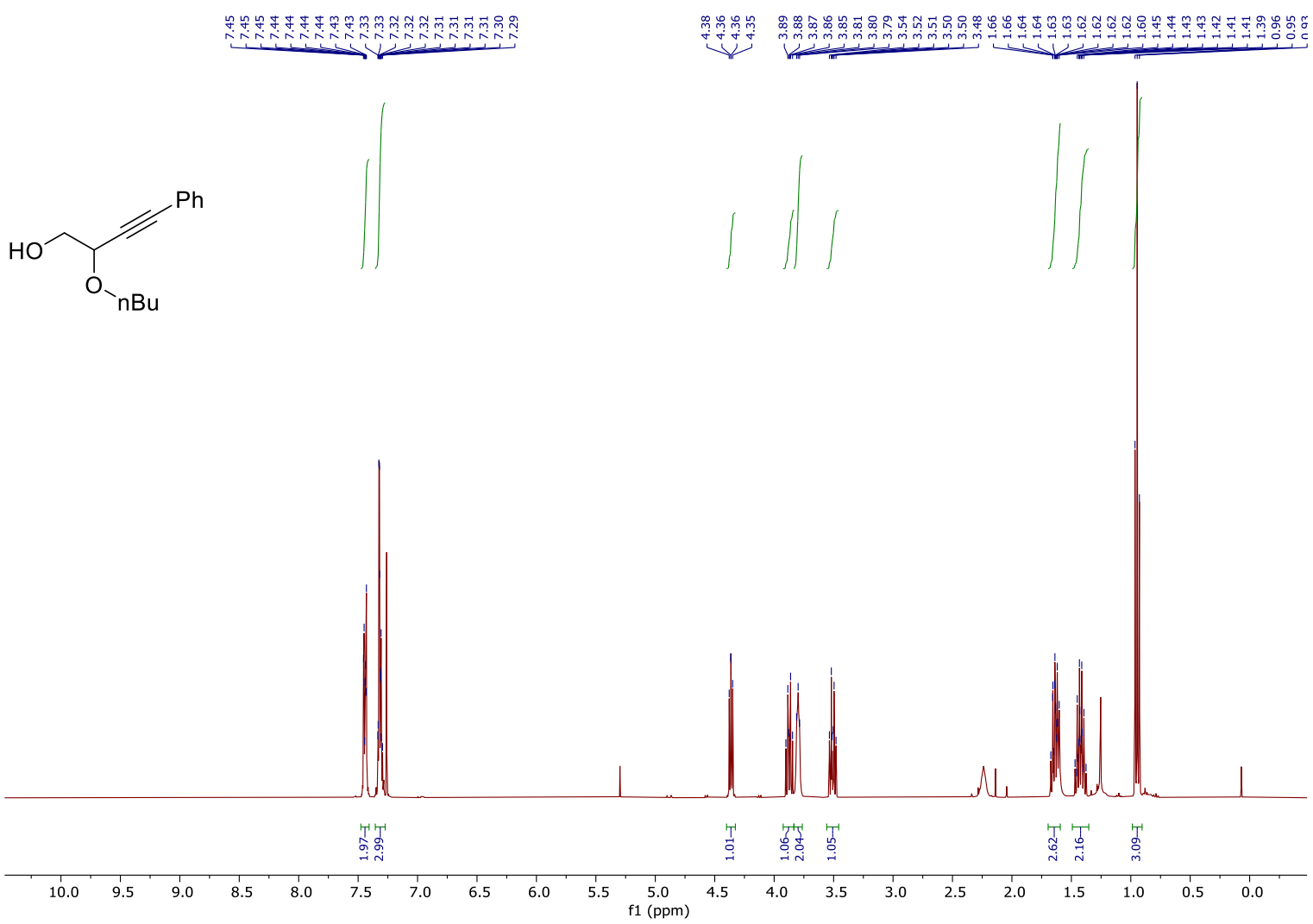

${ }^{13} \mathrm{C}$ NMR (400 MHz, chloroform-d) 


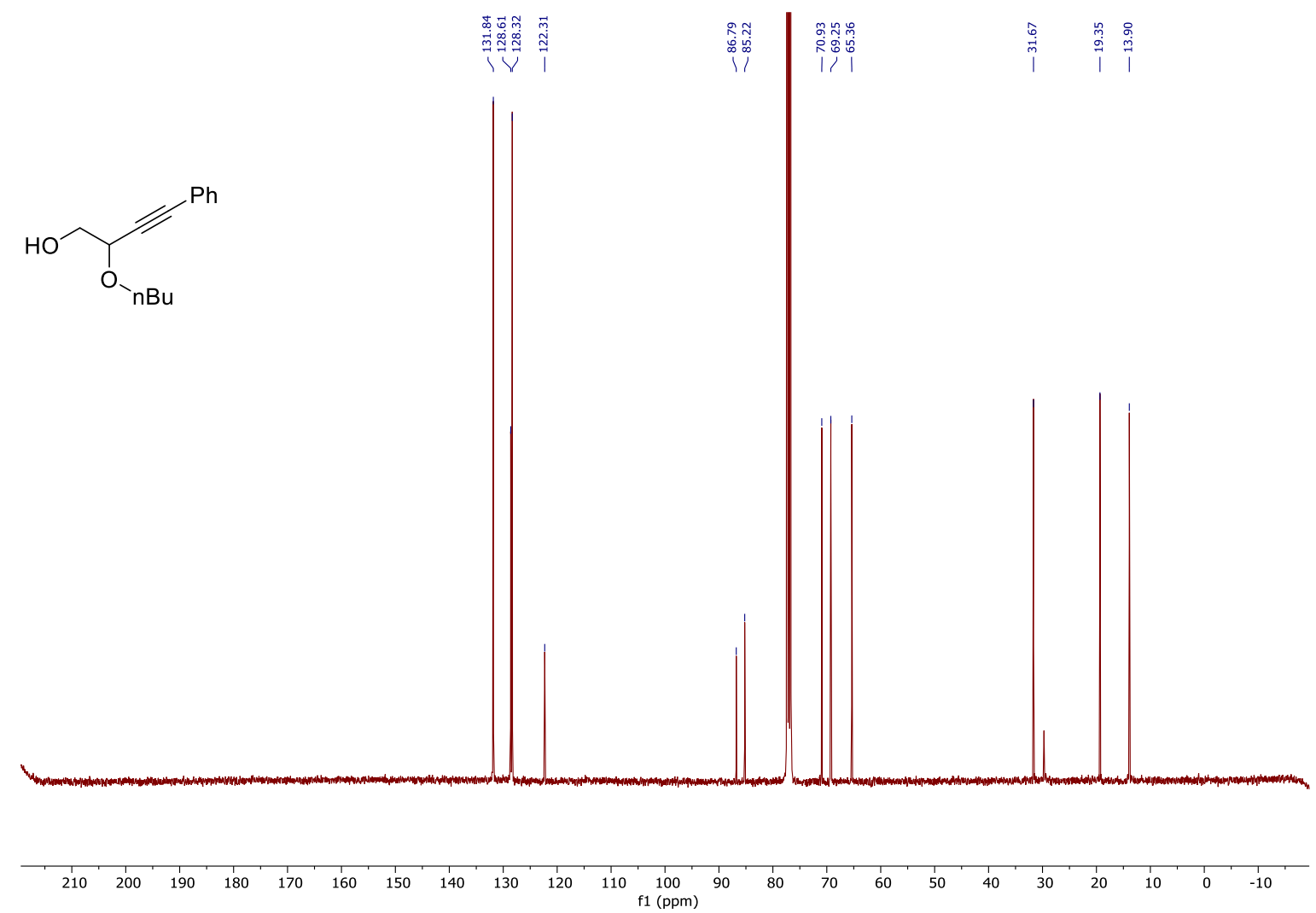


2-(phenethylamino)-4-phenylbut-3-yn-1-yl 2-iodobenzoate (15) ${ }^{1} \mathrm{H}$ NMR (400 MHz, Acetonitrile- $\left.d_{3}\right)$

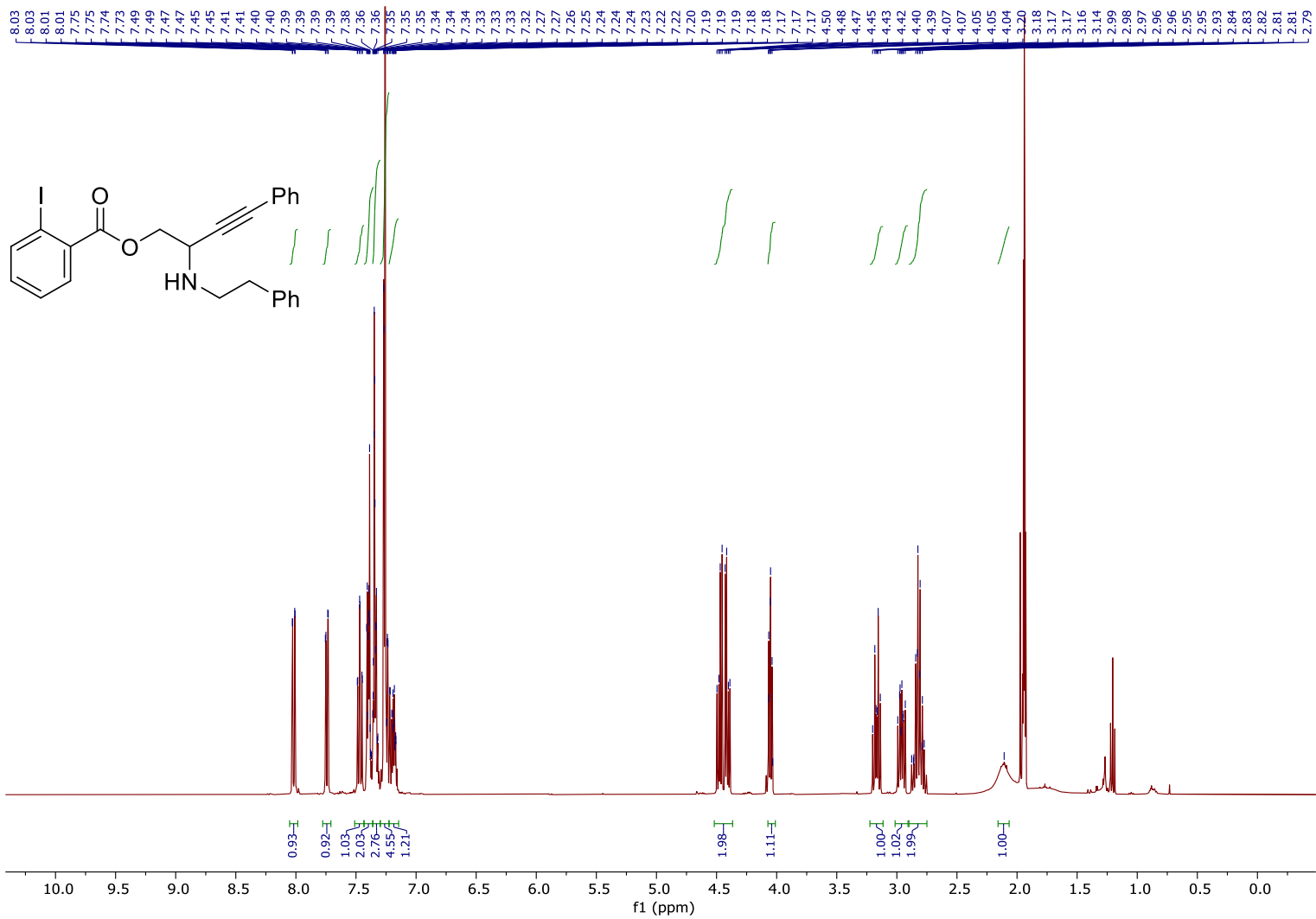

${ }^{13} \mathrm{C}$ NMR (101 MHz, Acetonitrile- $\left.d_{3}\right)$

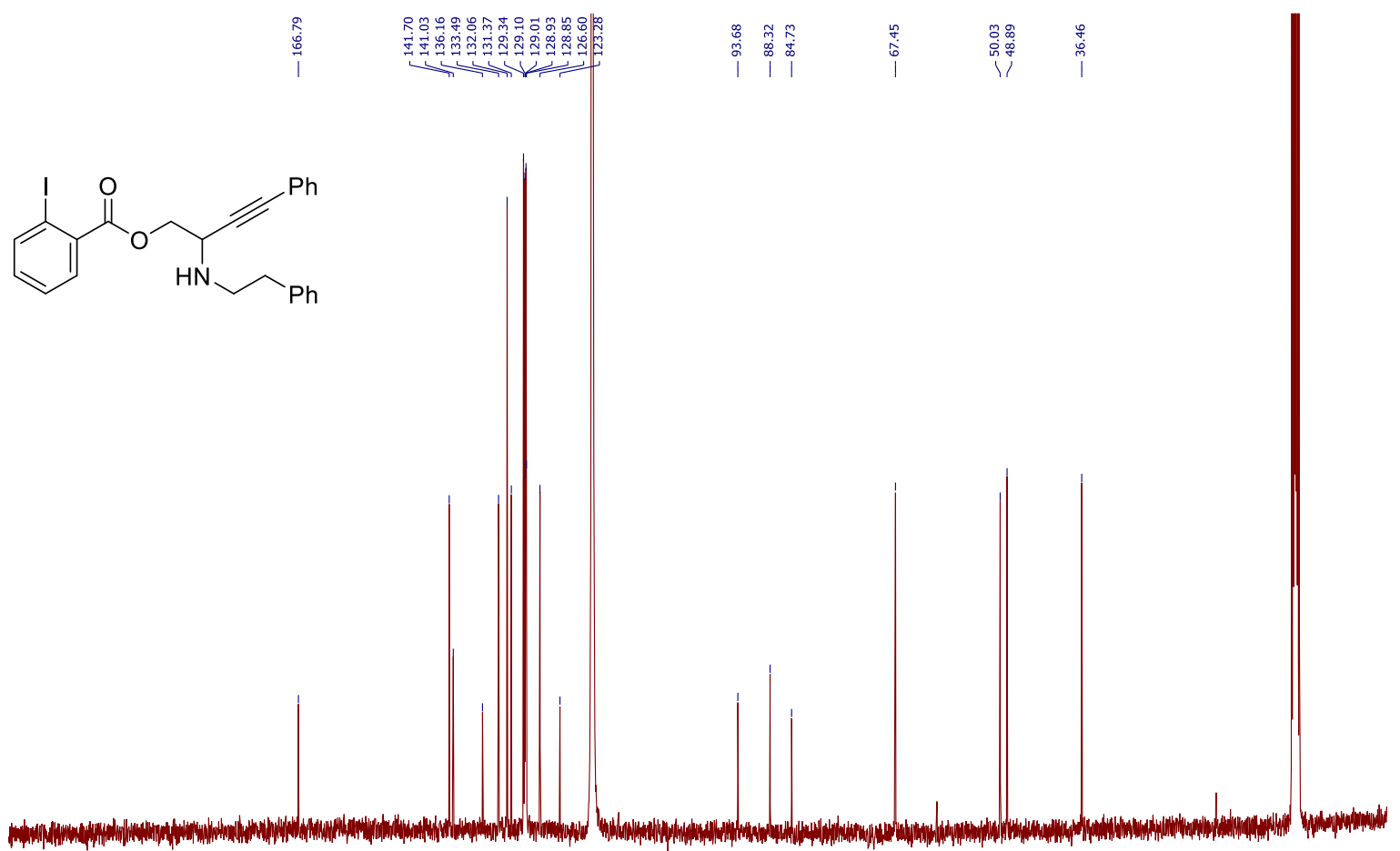

$\begin{array}{lllllllllllllllllllllllllll}210 & 200 & 190 & 180 & 170 & 160 & 150 & 140 & 130 & 120 & 110 & 100 & 90 & 80 & 70 & 60 & 50 & 40 & 30 & 20 & 10 & 0 & -10\end{array}$ 
